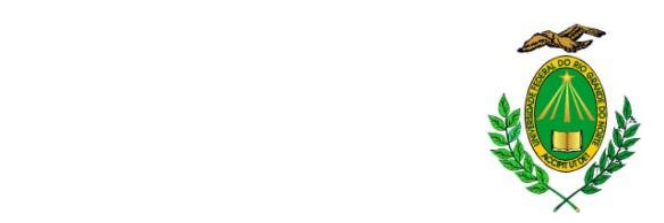

UNIVERSIDADE FEDERAL DO RIO GRANDE DO NORTE

CENTRO DE CIENCIAS HUMANAS, LETRAS E ARTES

MESTRADO EM CIÊNCIAS SOCIAIS

JUAN PABLO COUTO DE CARVALHO

\title{
A PREVIDÊNCIA RURAL UNIVERSALISTA E A SUA RELEVÂNCIA NA ECONOMIA DOS MUNICÍPIOS DO RIO GRANDE DO NORTE
}


A PREVIDÊNCIA RURAL UNIVERSALISTA E A SUA RELEVÂNCIA NA ECONOMIA DOS MUNICÍPIOS DO RIO GRANDE DO NORTE

Dissertação apresentada ao Programa de PósGraduação em Ciências Sociais (PPGCS) da Universidade Federal do Rio Grande do Norte, como exigência parcial para obtenção do título de Mestre em Ciências Sociais.

Orientador: Professor Doutor Lincoln Moraes de Souza

Natal

2010 
UNIVERSIDADE FEDERAL DO RIO GRANDE DO NORTE

CENTRO DE CIENCIAS HUMANAS, LETRAS E ARTES

PROGRAMA DE POS-GRADUACÃO EM CIÊNCIAS SOCIAIS

\title{
A PREVIDÊNCIA RURAL UNIVERSALISTA E A SUA RELEVÂNCIA NA ECONOMIA DOS MUNICÍPIOS DO RIO GRANDE DO NORTE
}

\author{
JUAN PABLO COUTO DE CARVALHO
}

Dissertação defendida e aprovada pela Banca Examinadora composta pelos(as) seguintes professores(as):

Prof. Dr. Lincoln Moraes de Souza

Orientador

Profa. Dra. Cimone Rozendo de Souza

Examinadora

Prof. Dr. João Matos Filho

Examinador

Prof. Dr. Guilherme da Costa Delgado

Examinador

Dissertação aprovada no dia 30 de setembro de 2010. 
A governabilidade está no social. A fome, a miséria, a ignorância, a doença são ingovernáveis. A injustiça social é a negação do governo e a condenação do governo (...).

(Discurso pronunciado por Ulysses Guimarães, na Sessão da Assembléia Nacional Constituinte, em 27 de julho de 1988). 


\section{RESUMO}

Este trabalho trata da previdência rural universalista instituída pela Constituição Federal de 1988 e a sua importância na economia dos municípios do Rio Grande do Norte. Neste contexto, o estudo busca satisfazer dois importantes critérios que orientam a seleção de objetos de pesquisa em ciências sociais: a consideração de questões que apresentam importância para o mundo real e a intenção de apresentar contribuição para a literatura acadêmica, em aspectos teóricos e empíricos. A investigação procura revelar qual é a importância econômica do subsistema de previdência social rural para os municípios do RN. A hipótese é de que a transferência de renda recebida pelos beneficiários a partir da previdência rural supera os mecanismos fiscais explícitos para maioria dos municípios do $\mathrm{RN}$, em vários casos significativamente, a revelar a importância desta política como mecanismo de combate a pobreza e a redução da desigualdade social, mormente ante a fragilidade do sistema federativo nacional quanto ao ente político municipal. O estudo apresenta núcleos teóricos capítulos 1 a 3 - e empírico - capítulo 4. O primeiro núcleo discorre sobre a evolução da proteção social enquanto política de Estado, abordando as influentes teorias e tipologias do Estado de Bem-Estar Social e as características do modelo previdenciário brasileiro, destacadamente, do seu subsistema de previdência social rural, de seus antecedentes até o modelo universalista inaugurado pela Constituição Federal de 1988. O segundo inicia com a revisão de estudos que têm enfatizado o impacto da Previdência Social sobre a economia local de pequenos municípios, para em seguida cruzar dados e estatísticas com o propósito de dimensionar a relevância socioeconômica da renda previdenciária rural nos municípios do Rio Grande do Norte. Para este fím, o último capítulo estabelece a comparação do valor monetário transferido pelo pagamento dos benefícios previdenciários - rurais e urbanos - a cada um dos 167 municípios do RN com as fontes de recurso igualmente importantes no orçamento destes entes municipais. Além das receitas tributárias próprias, são objetos de análise comparativa com o valor dos benefícios previdenciários emitidos no $\mathrm{RN}$, a transferência estadual referentes a cota parte do município sobre o ICMS e a transferência federal relativa ao FPM.

PALAVRAS CHAVES: proteção social, previdência rural, relevância, economia municipal. 


\begin{abstract}
This study deals with the rural social security Universalist established by the Constitution of 1988 and its importance in the economy of the municipalities of Rio Grande do Norte. In this context, the study seeks to satisfy two important criteria that guide the selection of objects of social science research: a consideration of issues that have relevance to the real world and the intention to make the contribution to the scholarly literature on theoretical and empirical aspects. The research seeks to reveal what is the economic importance of the subsystem of social security for rural municipalities in $\mathrm{RN}$. The hypothesis is that the transfer of income received by beneficiaries from the rural social security tax exceeds the explicit mechanisms for most municipalities in $\mathrm{RN}$, in many cases significantly, proving the importance of this policy as a mechanism for combating poverty and reducing social inequality, especially before the fragility of the federal system on the national political entity hall. The study presents theoretical cores - chapters 1-3 - and empirical - Chapter 4. The first core is about the evolution of social protection as a state policy, addressing the influential theories and typologies of the State of Social Welfare and the characteristics of the Brazilian social security model, but mainly, its rural social security subsystem, its history until universalistic model inaugurated by the Federal Constitution of 1988. The second begins with an overview of studies that have emphasized the impact of Social Security on the local economy of small municipalities, then passing data and statistics in order to gauge the socioeconomic importance of pension income in the rural municipalities of Rio Grande do Norte. To this end, the final chapter provides a comparison of the monetary value transferred by the payment of social security benefits - rural and urban - to each of the 167 municipalities in RN with the equally important sources of income in the budget of municipal entities. Apart from their own tax revenues, are objects of comparison with the value of pension benefits awarded in $\mathrm{RN}$, transfer quota state relating to the municipality on the federal ICMS and the transfer on the FPM.
\end{abstract}

KEY WORDS: social protection, rural social security, relevancy, municipal economy. 


\section{LISTA DE TABELAS}

Tabela 1 - Pobreza e indigência sem e com benefícios previdenciários (Brasil) - 2001 a 2008

Tabela 2 - Distribuição Federativa dos Recursos Disponíveis para Cada um dos Entes Federados do Brasil - 1960 a 2005.

Tabela 3 - Participação Relativa das Receitas Municipais segundo os Grupos de Habitantes no Ano de 2005 118

Tabela 4 - Arrecadação e Pagamento de Benefícios da Previdência Social por Décimos de Municípios Ordenados por PIB per capita Valores em R\$ correntes Milhões - 2006

Tabela 5 - Arrecadação e Pagamento de Benefícios por Tamanho da População Valores em R \$ correntes Milhões - 2006

Tabela 6 - Arrecadação e Pagamento de Benefícios Capitais das UFs x Demais Cidades Valores em R \$ correntes Milhões - 2006 125

Tabela 7 - Arrecadação e Valor dos Benefícios Emitidos por Região 2006 Valores em R\$ milhões correntes ou nominais ou em \% 126

Tabela 8 - Municípios por Região Brasileira em que o pagamento de benefícios supera o FPM em 2006 e 2008

Tabela 9 - Distribuição da PEA segundo o domicílio e status de ocupação em anos selecionados 136

Tabela 10 - Valor anual dos benefícios emitidos no RN, de 2001 a 2009, por clientela......138 


\section{LISTA DE GRÁFICOS}

Gráfico 1 - Quantidade de Benefícios Concedidos pela Previdência Social (2001 a 2009) acumulado até dezembro (em milhares de benefícios).

Gráfico 2 - Evolução da Arrecadação, Despesa de Benefícios e Necessidade de Financiamento do RGPS - RURAL - Em R \$ bilhões de dez/2009 (INPC)

Gráfico 3 - Necessidade de Financiamento do RGPS-RURAL em \% do PIB - 2005 a 2009.

Gráfico 4 - Evolução da Cobertura Social entre as Pessoas com Idade entre 16 e 59 anos 1992 a 2008

Gráfico 5 - Taxa de Cobertura da Força de Trabalho na América Latina. 103

Gráfico 6 - Brasil: Idosos de 60 anos ou mais que recebem aposentadoria e/ou pensão ou que continuam contribuindo para algum regime - 1992 a 2008 (em \%). 104

Gráfico 7 - Taxa de Cobertura da População Idosa na América Latina. 104

Gráfico 8 - Relação (Benefícios - Arrecadação)/PIB em \%

Gráfico 9 - Relação entre Benefícios Pagos e Transferência de FPM por Região em 2006 e 2008

Gráfico 10 - Quantidade de Benefícios emitidos no Brasil de 2001-2009

Gráfico 11 - Percentual de benefícios emitidos no Rio Grande do Norte, por clientela, 20012009 136

Gráfico 12 - Percentual do Valor dos benefícios emitidos no Rio Grande do Norte, por clientela, 2001-2009.

Gráfico 13 - Percentual do valor acumulado dos benefícios emitidos pelo INSS no Brasil, por clientela, 2001-2009.

Gráfico 14 - Distribuição de benefícios rurais emitidos no Brasil, segundo faixa de valores 140

Gráfico 15 - Evolução do Reajuste do Salário Mínimo, INPC, IPCA e IPC-3i, de 2002 a 2009. .141

Gráfico 16 - Evolução do Reajuste dos Benefícios Acima de 1 SM e INPC, IPCA e IPC-3i, de 2002 a 2009

Gráfico 17 - Cobertura Social por Unidade da Federação - 2008- (Inclusive Área Rural da Região Norte) - entre 16 e 59 anos de idade. 
Gráfico 18 - Cobertura Social por Unidade da Federação - 2008- (Inclusive Área Rural da Região Norte) - a partir de 60 anos de idade 144

Gráfico 19 - Pontos Percentuais de Redução de Pobreza no Brasil em função das Transferências Previdenciárias por UF - 2008 (Inclusive Área Rural da Região Norte)........147 Gráfico 20 - Linhas Comparativas de evolução do Valor dos Benefícios emitidos e da Arrecadação Previdenciária do Rio Grande do Norte, de 2001 a 2009 152

Gráfico 21 - Comparativo do Valor dos Benefícios emitidos com os Repasses de FPM e FPE para o RN. 154 


\section{LISTA DE QUADROS}

Quadro 1 - Resultado da Seguridade Social de 2000 a 2006.

Quadro 2 - Tipologia de Modelos de Cobertura Previdenciária Rural

Quadro 3 - Resumo das Principais Características e Tendências dos Modelos de Cobertura

Previdenciária Rural. .109

Quadro 4 - Dados Geográficos e Populacionais do Rio Grande do Norte. 128

Quadro 5 - PIB do Rio Grande do Norte. 129

Quadro 6 - IDH e mapa da pobreza e desigualdade do Rio Grande do Norte. 129

Quadro 7 - Educação do Rio Grande do Norte. 129

Quadro 8 - Saúde do Rio Grande do Norte. 130

Quadro 9 - Renda e Emprego do Rio Grande do Norte. 130

Quadro 10 - Informações Agropecuárias do Rio Grande do Norte. 130

Quadro 11 - Finanças Públicas do Rio Grande do Norte. 131

Quadro 12 - Quantidade de benefícios emitidos no mês de dezembro/2009, por UF. .134

Quadro 13 - Quantidade de benefícios emitidos no Rio Grande do Norte, por clientela.

Quadro 14 - Quantidade de créditos emitidos para pagamento de benefícios ativos no cadastro, por espécies, no Rio Grande do Norte, de 2001 a 2008.

Quadro 15 - Relação do PIB do RN com o Valor dos Benefícios e a Arrecadação Previdenciária. 151

Quadro 16 - Comparativo do Valor dos Benefícios emitidos com os Repasses de FPM e FPE para o RN. 


\section{LISTA DE APÊNDICES}

APÊNDICE I - Comparativo de Receita Municipal Total e Própria, das transferências Constitucionais (FPM e ICMS) e do Valor dos Benefícios emitidos, por município do Rio Grande do Norte - 2008 174

APÊNDICE II - Relação da Renda Previdenciária com o FPM e o IDH-M, por Município do Rio Grande do Norte - 2007. 181

APÊNDICE III - Relação do PIB Municipal com o Valor dos Benefícios emitidos Renda Previdenciária, por Município do Rio Grande do Norte. 188 


\section{LISTA DE ANEXOS}

ANEXO I - Valor anual dos benefícios emitidos pelo INSS, segundo os municípios do Rio Grande do Norte - 2000 a 2009 195

ANEXO II - Valor arrecadado pelo INSS, segundo os municípios do Rio Grande do Norte 2000 a 2009. 200 


\section{LISTA DE ABREVIATURAS E SIGLAS}

AEPS - Anuário Estatístico da Previdência Social.

AERN - Anuário Estatístico do Rio Grande do Norte.

ANFIP - Associação Nacional dos Auditores Fiscais da Receita Federal do Brasil.

BEPS - Boletim Estatístico da Previdência Social.

BPC - Benefício de Prestação Continuada de Assistência Social.

CAP - Caixa de Aposentadoria e Pensões.

CF - Constituição Federal.

CLT - Consolidação das Leis do Trabalho.

FINSOCIAL - Fundo de Investimento Social.

FPE - Fundo de Participação dos Estados.

FPM - Fundo de Participação dos Municípios.

FUNRURAL - Fundo de Assistência e previdência do Trabalhador Rural.

IAP - Instituto de Aposentadoria e Pensões.

IBAM - Instituto Brasileiro de Administração Municipal

IBGE - Instituto Brasileiro de Geografia e Estatística.

ICMS - Imposto sobre Operações relativas à Circulação de Mercadorias e Prestação de Serviços de Transporte Interestadual e Intermunicipal e de Comunicação.

IDH - Índice de Desenvolvimento Humano

IDH-M - Índice de Desenvolvimento Humano Municipal

INPS - Instituto Nacional de Previdência Social.

INSS - Instituto Nacional do Seguro Social.

IPASE - Instituto de Previdência e Assistência dos Servidores do Estado.

IPEA - Instituto de Pesquisa Econômica Aplicada.

IPI - Imposto sobre Produto de Industrializados. 
LOAS - Lei Orgânica da Assistência Social.

LOPS - Lei Orgânica da Previdência Social.

MF - Ministério da Fazenda.

MPS - Ministério da Previdência Social do Governo Federal do Brasil.

PASEP - Programa de Formação do Patrimônio do Servidor Público.

PIB - Produto Interno Bruto.

PIS - Programa de Integração Social.

PNAD - Pesquisa Nacional por Amostra de Domicílios.

PRORURAL - Programa de Assistência ao Trabalhador Rural.

RGPS - Regime Geral de Previdência Social.

RPPS - Regime Próprio de Previdência Social.

RMV - Renda Mensal Vitalícia.

RPPS - Regime Próprio de Previdência Social.

STN - Secretaria do Tesouro Nacional.

UF - Unidade da Federação 


\section{SUMÁRIO}

INTRODUÇÃO

CAPÍTULO I - A PREVIDÊNCIA COMO POLÍTICA ESTATAL DE PROTEÇão SOCIAL..............26

1. Razões para criação de Programas Obrigatórios de Previdência..........................................26

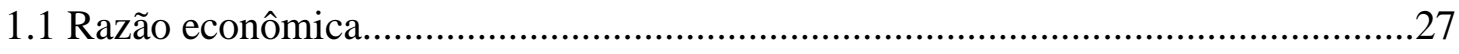

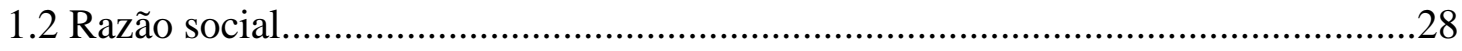

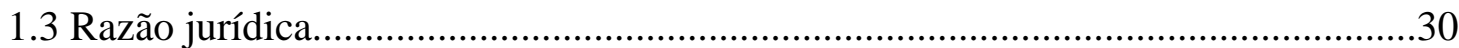

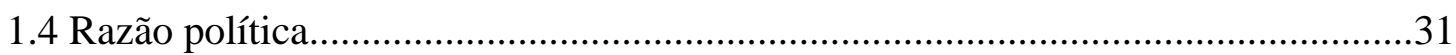

2. Surgimento da Previdência Social como obrigação do Estado............................................32

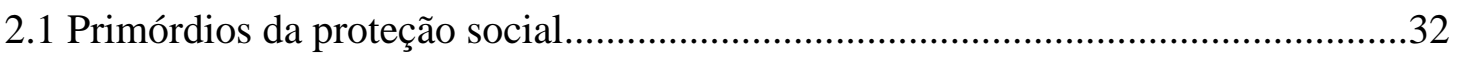

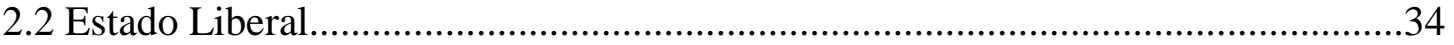

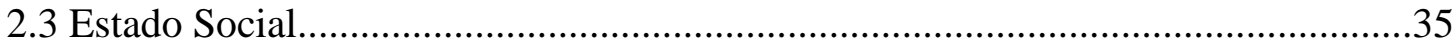

3. Considerações sobre a origem da proteção previdenciária estatal no Brasil........................49

CAPÍtUlo II - TiPologias do Estado de BEM-Estar E A TRAJETória da PROTEÇão

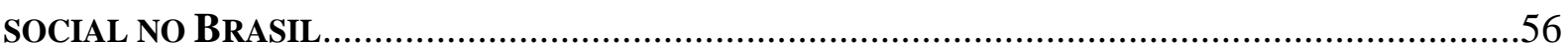

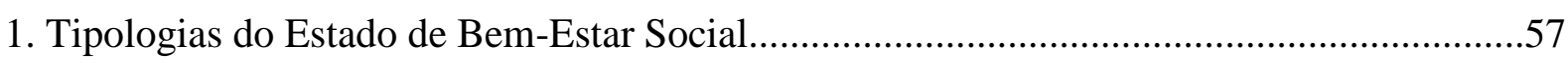

1.1 Os modelos bismarckiano e beveridgeano de Bem-Estar Social...........................57

1.2 A precursora tipologia tricotômica de Richard Titmuss e os três mundos do bemestar capitalista de Esping-Andersen......................................................................5

2. Estado de Bem-Estar Social no Brasil....................................................................................63

2.1 Antecedentes da Constituição Federal de 1988 ...................................................63

2.2 A Constituição Federal de 1988 e a Seguridade Social........................................69

CAPÍtulo III - PrevidênCIA RURAL no Brasil e no ConteXto InTERnaCional.....74

1. Evolução do sistema de proteção previdenciária ao trabalhador rural..................................74

1.1 Do início até a fase pré-Constituição Federal de 1988 .............................................74

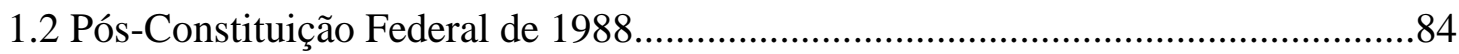

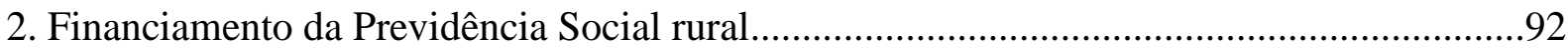

3. Impacto social da Previdência Social rural..................................................................... 100 
4. Previdência Rural no Contexto Internacional de acordo com a tipologia de Helmut Schwarzer. 106

\section{CAPÍtulo IV - A Relevância da PrevidênCIA Rural na Economia dos Municípios DO RN

1. Breve apresentação das características do Federalismo Brasileiro.....................................113

2. Composição das receitas municipais............................................................................116

3. Abordagem de pesquisas sobre o impacto da Previdência Social na economia dos municípios

4. Aspectos socioeconômicos do RN 128

5. Balanço Geral da Previdência Social no Rio Grande do Norte......

5.1 Quantidade de benefícios emitidos.

5.2 Valor dos benefícios emitidos no Rio Grande do Norte

5.3 Cobertura previdenciária do Rio Grande do Norte

5.4 Impactos da Previdência Social na renda da população e na redução do nível de pobreza....... .146

5.5 Benefícios Líquidos = benefícios emitidos - arrecadação previdenciária 150

5.6 Comparativo: valor dos benefícios x transferências fiscais 


\section{INTRODUÇÃO}

O tema do presente estudo é a previdência rural universalista instituída pela Constituição Federal de 1988 e a sua importância na economia dos municípios do Rio Grande do Norte.

A escolha do tema surgiu naturalmente do cotidiano profissional do autor na condição de docente na área de Previdência Social e no exercício do cargo de procurador federal junto à Procuradoria Federal Especializada do Instituto Nacional do Seguro Social (INSS), órgão de execução da Advocacia-Geral da União.

A relevância do tema exsurge do fato da previdência rural representar um dos mais importantes programas de transferência de renda do país, incidindo diretamente sobre falhas marcantes do federalismo e da economia brasileira, a exemplo da concentração de receita nos entes federativos maiores, da baixa formalização do trabalho no campo e da desigualdade social, constituindo-se, assim, importante fonte de subsistência da população rural e elemento dinamizador da economia dos municípios.

Segundo a Pesquisa Nacional por Amostra de Domicílios (PNAD), referente ao ano de 2008, os domicílios rurais abrigam pouco mais de $16 \%$ do total de habitantes no País. Essa proporção é maior nas regiões Nordeste e Norte, com $27,6 \%$ e $22 \%$, respectivamente. O Sudeste é a região mais urbanizada do País, com apenas $8 \%$ de sua população residindo na zona rural. Paradoxalmente, é no Sudeste que está a segunda maior concentração de população rural, representando $20,5 \%$ da população rural brasileira. Nesse quesito, só perde para a região Nordeste que concentra $48 \%$ da população rural.

A despeito da menor importância relativa do contingente populacional rural em face do contingente urbano, dadas as dimensões continentais do Brasil, estamos ainda a tratar de uma população superior a 30 milhões de pessoas.

Como o trabalho se apóia, principalmente, em dados e estatísticas do Ministério da Previdência Social (MPS), adotamos a conceituação deste órgão governamental para distinguir as clientelas rural e urbana. Isto significa que o enquadramento da clientela urbana e 
rural é determinado pela natureza da ocupação ou atividade que o segurado exerce, independentemente da área geográfica em que ele resida. Por exemplo, uma pessoa que mora na área urbana, mas trabalha no meio rural é enquadrada na clientela rural, assim como, inversamente, uma pessoa que mora na área rural, mas trabalha como vendedor de uma loja na área urbana, é enquadrada como segurado urbano.

No Rio Grande do Norte, a quantidade de benefícios concedidos em favor da clientela rural pelo Regime Geral de Previdência Social (RGPS), administrado pelo Instituto Nacional de Seguro Social (INSS), é superior aos emitidos favoravelmente à clientela urbana, embora o volume monetário repassado a este segmento previdenciário supere o transferido àquela, em decorrência da média mais elevada do valor dos benefícios de origem urbana.

Os benefícios consistem em prestações pecuniárias pagas pela Previdência Social aos segurados ou aos seus dependentes, de forma a atender a cobertura dos eventos de doença, acidentes do trabalho, invalidez, morte ou idade avançada, bem como tempo de contribuição e o trabalho sujeito a condições especiais; a proteção à maternidade; salário-família e auxílioreclusão; e as prestações assistenciais pagas às pessoas idosas ou portadoras de deficiência.

De acordo com os dados do MPS (2009), em julho de 2009, a soma dos benefícios emitidos pelo Regime Geral de Previdência Social, no Rio Grande do Norte, totalizou 453.681. Para que se alcançasse esse número, a clientela rural contribuiu com 237.606 beneficiários e a clientela urbana com 216.075. O conjunto desses beneficiários da Previdência Social foi contemplado com a transferência de recursos financeiros da ordem de $\mathrm{R} \$ 224,86$ milhões.

Em números absolutos, essa transferência de renda promovida pela Previdência Social superou o repasse do Fundo de Participação dos Municípios (FPM), no Rio Grande do Norte. Dados da Secretaria do Tesouro Nacional (STN) indicam que a soma dos pagamentos dos benefícios previdenciários à população rural e urbana do Rio Grande do Norte nos anos de 2008 e 2009 foram aproximadamente duas vezes e meia superior ao repasse do FPM para os municípios potiguares, no mesmo período.

Uma das formas de conhecer o efeito redistributivo proporcionado pela previdência rural no Rio Grande do Norte dá-se subtraindo o valor dos benefícios emitidos (transferência 
de rendas previdenciárias) e o correspectivo valor arrecadado no mesmo período no estado. $\mathrm{O}$ valor arrecadado compreende os recolhimentos provenientes de todas as receitas incluídas na guia de recolhimento da Previdência Social - GPS. E o valor dos benefícios emitidos corresponde ao valor líquido (diferença entre valor bruto e descontos) dos créditos emitidos na folha de pagamentos da Previdência Social (maciça), classificados pelo município do órgão pagador (onde o segurado recebe seu benefício).

No ano de 2008, os 167 municípios do RN arrecadaram R\$ 1.167 bilhões em receita previdenciária e receberam em transferência de rendas o valor líquido de $\mathrm{R} \$ 2.515$ bilhões (MPS/EMPS, 2008), gerando, assim, para estes municípios superávit da ordem de R 1.348 bilhões.

O referencial primário para a caracterização de políticas redistributivas é constituído pela tipologia proposta por Lowi (1964) para a classificação de políticas públicas. De acordo com a sua contribuição seminal, as políticas redistributivas são aqueles que proporcionam a redistribuição de vantagens ou benefícios entre grupos sociais, subtraindo recursos de um determinado grupo em favor de outros, buscando equidade e provocando conflitos.

Analisando vários trabalhos sobre a tipologia de Lowi, explica Souza (2010, p. 09) que as arenas ou políticas redistributivas "seriam vistas como tomando benefícios de outros grupos, envolvendo conflitos sobre legitimidade da ação e do conteúdo específico. As demandas estariam associadas a uma retórica de luta de classes e integradas (coesão de membros do grupo etc.), pressuporiam um executivo forte e exemplifica estas políticas com taxações".

Justamente em razão de a pesquisa tratar de uma de uma política pública de perfil redistributivo criada com propósitos de gerar mudanças na realidade onde é aplicada, aqui se buscou, ainda que indiretamente, aproximação ao estudo de avaliação de políticas públicas que Figueiredo e Figueiredo (1986) classificam como "análise de impacto", a partir do qual se espera identificar os efeitos da política previdenciária rural sobre a população-alvo, tendo, subjacente, a intenção de estabelecer uma relação de causalidade entre a política e as alterações nas condições socioeconômicas dos municípios potiguares. 
Figueiredo e Figueiredo (1986, p. 115) afirmam que políticas com propósitos de mudança

\begin{abstract}
(...) reservam em si a importância de causarem um efeito esperado, o que condiciona a avaliação ao uso de um critério de aferição de mudanças e de modelos analíticos causais. Diz-se que essas políticas ou programas obtiveram sucesso quando se pode imputar a eles a condição de causa necessária, quando não suficiente, de uma mudança observada. Ou seja, a constatação de que ocorreram mudanças não é suficiente concluir-se pelo sucesso do programa; é necessário demonstrar que elas não ocorreriam (total ou parcialmente) sem o programa. Em outros termos, é necessário demonstrar que a atuação do programa é empiricamente relevante na determinação da mudança observada (Bennett e Lumsdaine, 1975; Campbell, 1969, 1972).
\end{abstract}

A noção de causalidade embutida nas políticas com propósitos de mudança estabelece, ademais, que essas políticas são ações experimentais por excelência; são condições que visam alterar o futuro previsível dado pela inércia social. (...)

Assim, dentro da multiplicidade de resultados apontados por Figueiredo e Figueiredo (1986) como passíveis de advir de políticas com propósitos de mudanças, pretende-se apresentar elementos quantitativos e qualificativos reveladores de que o resultado esperado pela política estudada foi alcançado, no sentido em que seus efeitos contribuíram para um aumento ou uma melhor distribuição de bem-estar e cidadania à população-alvo.

Sem prejuízo das digressões históricas, a pesquisa está circunscrita ao período pósConstituição de 1988, a partir de quando se verificaram mudanças estruturais no subsistema de proteção social do setor rural.

O modelo de proteção previdenciária brasileiro assegurou aos agricultores em regime de economia familiar e aos pescadores artesanais, denominados pela legislação de regência como "segurados especiais", acesso diferenciado aos benefícios previdenciários. Nesse modelo, o segurado especial não precisa ter contribuído diretamente para o sistema previdenciário, como ocorre com as demais categorias de segurados da Previdência Social. O requisito básico exigido é a comprovação de seu enquadramento nas categorias profissionais que legalmente o qualificam como segurado especial.

Não significa que os segurados especiais estejam imunes de contribuir para o sistema previdenciário a que estão inseridos. Entretanto, diferentemente das demais categorias de segurados - empregado, contribuinte individual, trabalhador avulso, empregado doméstico e facultativo -, sua contribuição incide apenas sobre o resultado da comercialização do 
excedente eventualmente produzido e o respectivo recolhimento da contribuição previdenciária fica ao encargo do adquirente de sua produção comercializada.

Com isso, criou-se um regime especial de segurados rurais dotado de peculiaridades em relação ao sistema previdenciário brasileiro. Tem-se, hoje, dentro do chamado Regime Geral da Previdência Social (RGPS) um subsistema de previdência urbana, vinculado ao contrato formal de trabalho e na contributividade, nos moldes de um seguro social contratual, com perfil meritocrático; e outro subsistema de previdência rural, ancorado no reconhecimento do trabalho informal, que flexibiliza a exigência de contribuição direta do segurado, o que o aproxima do modelo teórico redistributivo de proteção social.

Por definição constitucional, os segurados urbanos e rurais são beneficiários do Regime Geral de Previdência Social indistintamente. Fazem jus assim aos mesmos serviços e prestações previdenciários, financiados pela mesma pluralidade de fontes. Por esse motivo, não é adequado dizer que os benefícios previdenciários rurais têm natureza assistencial, porquanto, o acesso da clientela rural aos benefícios da previdência se dá pelo exercício de atividade laboral e não em função de uma necessidade econômica ou da incapacidade para prover o próprio sustento, estando nesta distinção umas das principais marcas diferenciadoras do sistema previdenciário em relação ao assistencial.

A adoção do subsistema de contribuição diferenciada de previdência rural acabou por reconhecer que o modelo de Previdência Social adotado no Brasil para o setor urbano, que pressupõe que os trabalhadores tenham vínculos de trabalho formal e rendimentos regulares, não podia ser aplicado indistintamente ao setor rural. Os trabalhadores rurais não contam com rendimentos regulares (muitos vivem da produção para o autoconsumo, com inexpressivo rendimento monetário), nem se classificam, de modo geral, como assalariados.

Mesmo assim, o alargamento da cobertura previdenciária dos trabalhadores rurais foi tão substancial que Schwarzer (2000a, p. 01) avaliou que "o subsistema rural da Previdência Social brasileira parece ser, entre os casos conhecidos em países chamados em desenvolvimento, um programa social excepcional quanto ao significativo grau de cobertura, à alta precisão do targeting e parece formar um programa que tem uma efetividade inédita no combate à pobreza no meio rural brasileiro". 
De fato, o sistema previdenciário brasileiro, sobretudo o englobado pelo Regime Geral de Previdência Social (RGPS), propicia um dos mais altos níveis de cobertura na América Latina em seu subsistema de previdência rural. A cobertura previdenciária da população brasileira idosa, que inclui os aposentados, pensionistas e contribuintes em atividade, com idade igual ou superior a 60 anos, evoluiu de 74,03\% em 1992 para 81,79\% em 2008. No Rio Grande do Norte, a média da cobertura previdenciária aos idosos é de $87 \%$, a quarta maior do país, ficando atrás apenas do Piauí $(90,4 \%)$, Santa Catarina $(89,6 \%)$ e Rio Grande do Sul $(88,7)$.

De acordo com dados da PNAD 2008, pode-se observar que a transferência de renda através do pagamento de benefícios previdenciários repercute significativamente no combate à pobreza da população brasileira. Se fossem excluídos os benefícios previdenciários pagos pela Previdência Social, a população extremamente pobre (pessoas que vivem com renda domiciliar per capita inferior a 1/4 de salário mínimo) cresceria, no ano de 2008, em mais de 17 milhões de indivíduos; e a população absolutamente pobre (pessoas que vivem com renda domiciliar per capita inferior a $1 \frac{1}{2}$ de salário mínimo), em quase 21 milhões. Ou seja, o percentual de pessoas em situação de extrema pobreza praticamente dobraria de 10,74\% para 20,19\% da população, enquanto o percentual de absolutamente pobres subiria em mais de um terço ao passar de 29,18\% para 40,56\%. Esses números apontam a importância da proteção previdenciária no combate à indigência e à pobreza no Brasil.

No Rio Grande do Norte, as transferências previdenciárias reduzem o contingente de pessoas vivendo abaixo da linha de pobreza em 14,1\%, proporção superior à média nacional que é de $12,3 \%$. Esse dado o coloca na posição de sexta maior redução entre os estados brasileiros.

O presente estudo verificará que a evolução destes indicadores da proteção social brasileira e potiguar, mormente, entre os idosos, deve-se significativamente à instituição da categoria de segurado especial pela Constituição Federal de 1988, regulamentada pela Lei n $^{\circ}$ 8.213, de 1991, que possibilitou a expansão da cobertura previdenciária no meio rural.

Estes esclarecimentos introdutórios confluem para o objetivo primordial do presente trabalho: investigar a relevância da transferência de renda da previdência rural para economia dos municípios do Rio Grande do Norte. Neste sentido, buscamos satisfazer dois importantes 
critérios que orientam a seleção de objetos de pesquisa em ciências sociais: i) a consideração de questões que apresentam importância para o mundo real; e ii) a intenção de contribuir para a literatura acadêmica, tanto nos aspectos teóricos quanto nos empíricos.

O problema que se pretende responder com o presente estudo é: qual é a importância econômica da Previdência Social rural para os municípios do Rio Grande do Norte?

Para responder a essa questão, trabalharemos com a hipótese geral de que a transferência de renda recebida pelos beneficiários da previdência rural potiguar pode superar as rendas e transferências fiscais da maioria dos municípios do $\mathrm{RN}$ e revelar, conseqüentemente, a importância da política de proteção previdenciária para o combate à pobreza e a redução das desigualdades sociais, no âmbito das municipalidades.

$\mathrm{Na}$ realização da pesquisa serão adotados dois procedimentos metodológicos. O primeiro consistirá na revisão de literatura sobre a matéria, para a qual foram selecionados textos de várias naturezas: textos de referência conceitual, textos de referências históricas, informes institucionais, estudos técnicos, textos legais e normativos.

Em seguida à revisão bibliográfica, desenvolver-se-á a análise de dados sobre a Previdência Social, em particular daqueles relacionados à previdência rural no Rio Grande do Norte, a partir de três fontes de dados principais. A primeira e mais importante delas são os documentos oriundos do Ministério da Previdência Social (MPS), representados por seus bancos de dados estatísticos, insertos em seus anuários e boletins, e os estudos analíticos existentes. A segunda fonte de dados serão as Pesquisas Nacionais por Amostra de Domicílios (PNADs), elaboradas pelo Instituto Brasileiro de Geografia e Estatística (IBGE), as quais apresentam informações referentes aos domicílios e às famílias brasileiras em diversas áreas, tais como: rendimento, emprego, educação e condições dos domicílios, entre outras. A terceira fonte consistirá nas informações a respeito das principais receitas auferidas pelo Estado e os municípios do Rio Grande do Norte, conforme documentos da Secretaria do Tesouro Nacional do Ministério da Fazenda (STN/MF).

A partir desse acervo documental, serão cruzados os dados disponíveis, a exemplo da comparação entre o volume de recursos transferidos aos moradores de cada município norterio-grandense pela Previdência Social rural e a quantia de tributos arrecadados pelos 
municípios potiguares ou decorrentes das principais transferências oriundas dos governos federal e estadual, com o objetivo de mensurar a relevância da universalização da previdência rural sobre a economia das municipalidades analisadas. São exemplo de tais transferências o Fundo de Participação de Municípios (FPM), o Fundo de Participação dos Estados (FPE) e a cota do Imposto sobre Circulação de Mercadorias e Prestação de Serviços (ICMS).

A pesquisa pretende produzir subsídios para ações relacionadas ao projeto de Previdência Social como política pública de redistribuição de renda, de redução da pobreza e das desigualdades regionais. Espera, com isso, lançar luzes e contribuir para a discussão a respeito de um melhor direcionamento dos gastos da previdência na área social, principalmente, nas áreas onde se concentra a maior parte da pobreza, no Estado do Rio Grande do Norte.

O trabalho está estruturado em quatro capítulos, além das considerações finais, apêndices e anexos.

O primeiro capítulo busca historiar o surgimento da Previdência Social como sistema estatal de proteção social, com ênfase para as razões econômicas, sociais, jurídicas e políticas que motivaram a criação de sistemas previdenciários públicos. Em seguida, discorrer-se-á sobre a evolução e o desenvolvimento histórico das medidas de proteção social, desde os seus primórdios até o surgimento do chamado Estado de Bem-Estar Social. O capítulo termina abordando aspectos gerais do surgimento da Previdência Social no Brasil.

O segundo capítulo abordará as mais influentes teorias e tipologias do Estado de BemEstar Social e a evolução do modelo de proteção social brasileiro, com destaque para suas principais características, antes e depois da Constituição Federal de 1998.

O terceiro capítulo tratará da previdência social rural, no Brasil, a partir do estudo dos seus antecedentes históricos e legais até o detalhamento e a análise crítica das principais regras de custeio e de benefícios do novel modelo instituído pela Constituição Federal de 1988.

No capítulo final se fará o estudo do impacto da Previdência Social rural sobre a economia local dos pequenos municípios, com destaque para a relevância socioeconômica da 
renda previdenciária rural para os municípios do Rio Grande do Norte. Com essa finalidade, proceder-se-á a comparação dos valores monetários transferidos a cada um dos 167 municípios do RN pelo pagamento dos benefícios previdenciários - rurais e urbanos - com as fontes principais de recursos que integram o orçamento das municipalidades potiguares. Além das receitas tributárias próprias, serão objeto de análise comparativa com o montante pago a título de benefícios previdenciários no $\mathrm{RN}$, a transferência estadual referente à cota parte de cada município sobre o ICMS e a transferência federal do Fundo de Participação dos Municípios (FPM).

A última parte da dissertação consistirá na apresentação das considerações finais sobre o tema abordado ao longo dos capítulos antecedentes. 


\section{CAPÍTULO I}

\section{A PREVIDÊNCIA COMO POLÍTICA ESTATAL DE PROTEÇÃO}

A adequada compreensão da realidade demanda o exame de sua evolução ao longo do tempo. A compreensão da previdência social, pela sua complexidade inconteste, demanda uma abordagem que leve em conta o processo histórico e as influências culturais, sociais e econômicas que contextualizaram a sua emergência como política estatal de proteção social. Por essa razão, este capítulo abordará, concomitantemente, o processo de evolução da previdência social em sintonia com o desenvolvimento do próprio ente estatal, ao longo da história.

\section{Razões para a criação de programas obrigatórios de previdência.}

Alguém poderia sustentar que caberia ao trabalhador, e somente a ele, proteger-se dos infortúnios da vida (morte, acidente, invalidez, doença, velhice, etc.), seja pela assistência de seus familiares ou da comunidade a que pertence, seja pela acumulação de riqueza ao longo de sua vida útil laborativa.

Assim, o ponto de partida lógico para qualquer discussão que tenha como pano de fundo a previdência é discutir as razões pelas quais existem programas previdenciários públicos. Ou seja, examinar quais os fundamentos que usualmente são apresentados para justificar essa prática social generalizada de impor substancial ônus financeiro ${ }^{1}$ à sociedade, em troca de prestações pecuniárias e serviços, quando surgem necessidades sociais decorrentes da velhice, da doença, da invalidez, da morte, da prisão, do desemprego e da maternidade.

\footnotetext{
${ }^{1}$ Para ilustrar, em 2006, a soma de todas as despesas com previdência pública no Brasil (incluído gastos com LOAS e RMV) comprometeu 11,7\% do PIB nacional. Sendo 7,6\% do PIB absorvido pelo RGPS e 4,1\% pelos RPPSs (Caetano; Rocha, 2008, p. 10).
} 
Há bastante tempo, os governos assumiram alguma responsabilidade pela garantia de um padrão de vida mínimo para os idosos e enfermos. Em muitos países, os programas de Previdência Social se tornaram importantes mecanismos para o cumprimento dessa responsabilidade. Entretanto, cresceram até muito além do nível necessário para garantir um padrão mínimo de vida socialmente aceitável, o que sugere que as razões para a sua criação vão além da exigência do rendimento mínimo. É essa motivação maior que sugere outras funções para a previdência pública, a exemplo, da redistribuição de riqueza e da diminuição da pobreza.

Atualmente, existe razoável consenso sobre a necessidade de intervenção do Estado na montagem, manutenção e físcalização dos sistemas previdenciários. Defensores e críticos destes sistemas concordam que os governos devem exigir que as pessoas em idade de trabalhar cuidem da sua aposentadoria, embora haja divergência quanto aos mecanismos recomendáveis para isso. $\mathrm{O}$ acordo quanto à necessidade da intervenção governamental demonstra que mercado livre não se presta à garantia previdenciária de todos os cidadãos.

Neves (1996) indica quatro razões fundamentais para a existência de sistemas de Previdência Social organizados pela iniciativa estatal, a saber, razões de natureza econômica, social, jurídica e política.

\subsection{Razão econômica}

A razão econômica para a intervenção estatal na organização de sistemas previdenciários considera que a perda de rendimentos e os efeitos materiais negativos de fatos existenciais como a morte, a invalidez, a velhice, o desemprego e a maternidade apresentam sérias implicações para as modernas sociedades. Diante disso, a preocupação com a criação e o funcionamento dos sistemas previdenciários não pode ser considerada um problema da alçada individual de cada cidadão. Pelo contrário, diz respeito ao conjunto da sociedade, o que, conseqüentemente, reclama a participação efetiva do Estado nessa questão.

É do interesse da própria atividade econômica que não haja excessivas alterações nos níveis dos rendimentos das pessoas atingidas pelos efeitos das principais contingências da 
vida humana. De fato, a diminuição da capacidade de consumo dos indivíduos e das famílias atingidas pelos infortúnios ou mudanças nas condições de suas vidas é susceptível de originar necessidades econômicas mais ou menos graves, capazes de causar perturbações no sistema produtivo das empresas e do país.

A superação dos efeitos danosos dos riscos sociais exprime, desse modo, o interesse coletivo, atinente ao bem comum, ao equilíbrio da atividade produtiva e à repartição dos rendimentos gerados individual ou coletivamente. Daí porque o Estado, cuja missão ideal é servir a sociedade com justiça e equidade, tem o dever de intervir adequadamente para garantir existência políticas previdenciárias, a exemplo do que faz nas áreas de segurança, educação e justiça, etc. Por isso mesmo, muito dos riscos da existência passaram a ser considerados riscos sociais cujo enfrentamento deve ser feito de forma coletiva e mediante organismos públicos adequados.

\subsection{Razão social}

A razão social diz respeito à constatação de que as pessoas, dotadas de liberdade individual, sujeitas ao princípio da autonomia da vontade, manifestam com facilidade e freqüência uma considerável incapacidade de tomarem pessoalmente medidas de autoproteção contra as consequências dos riscos sociais.

É dizer, muitas pessoas que trabalham e que poderiam adequadamente cuidar do próprio futuro são negligentes ou imprudentes quanto ao planejamento de sua inatividade. $\mathrm{Na}$ ausência da obrigatoriedade imposta pelo governo, elas não têm a visão ou a disciplina de poupar o suficiente para a aposentadoria. Quando percebem seu erro, já é tarde demais.

Neves (1996) chama esta espécie de demissão de responsabilidades individuais, de “incapacidade previdencial dos cidadãos”. E expõe alguns motivos que justificariam a fragilidade da posição individual perante a agressividade dos riscos:

a) Há pessoas que não são sensíveis à probabilidade de ocorrência de riscos (não pensam nisso) ou, se encaram esta probabilidade, fazem-no com um deficiente enquadramento temporal ou errada percepção da amplitude dos efeitos; 
b) Outras pessoas ainda, numa atitude de anti-seleção, só se dispõem a tomar uma decisão quando o risco ocorre ou se sofrem de graves predisposições neste sentido;

c) Finalmente, não faltam casos em os indivíduos verificam que não dispõem de recursos econômicos suficientes para assumirem sozinhos uma responsabilidade de autoproteção adequada, tanto no imediato, como a longo prazo. (p. 23)

Já Thompson (2000) defende que a imprevidência individual pode ser reduzida mediante educação e se forem oferecidos subsídios à poupança para a aposentadoria. Porém, reconhece que algum grau de compulsão é provavelmente inevitável, pois o imprudente não pouparia nem mesmo quando subsidiado, e a dimensão do subsídio necessário para superar os casos mais severos de miopia poderia ser inaceitável.

Assim, é certo afirmar que a intervenção do governo é necessária para proteger a parte prudente da sociedade contra aqueles que agem imprudentemente. Se as pessoas acabam acreditando que o governo vai garantir a todos os idosos um padrão de vida mínimo, muitas delas podem ser estimuladas a não poupar por conta própria, causando prejuízo àqueles que fielmente contribuem para o sistema previdenciário:

\footnotetext{
Para compreender melhor tal fundamento, costuma-se aludir a um exercício fictício de atuária: caso existisse um Estado com apenas 100 habitantes, dos quais todos trabalhadores, e apenas 50 deles contribuíssem para a formação de um fundo previdenciário, caso os 50 restantes, não contribuintes, se tornassem incapazes para o trabalho, caberia àqueles "previdentes" que contribuíram e formaram a poupança amparar os "imprevidentes", o que lhes acarretaria um encargo "em dobro". (Castro; Lazzari, 2008, p. 51)
}

Em razão disso, é que o Estado age em defesa do interesse coletivo e estabelece a filiação obrigatória à Previdência Social, como forma de garantir que o ônus dos riscos sociais não afete injustamente a parte previdente da sociedade.

Ainda que alguém conteste a imprevidência de parte considerável da sociedade, a tese de transferir a cada trabalhador a responsabilidade por sua subsistência futura esbarra em situações como a daquele trabalhador que, ainda no início da sua vida produtiva, venha a sofrer um acidente que o torne incapaz para o trabalho. Por mais consciente da necessidade de contribuir para o fundo previdenciário coletivo, o segurado não estará imune à ocorrência de um infortúnio que o obrigue a fazer uso do fundo previdenciário coletivo. Daí porque a mera poupança individual é incapaz de segurar o trabalhador contra todos os riscos de sua atividade laboral, o que justifica a intervenção estatal nos assuntos previdenciários. 
Thompson (2000) destaca ainda que as sociedades usam os mercados para organizar a sua atividade econômica. Todavia, há de se considerar que a iniciativa privada, movida que é pela busca constante de lucro, apresenta debilidades para operar os sistemas previdenciários e fazê-los alcançar os importantes objetivos sociais a que se destinam. Por isso, somente os programas públicos e obrigatórios de previdência social, sob forte subsídio do Estado e diversidade das fontes de custeios, poderão garantir a extensiva cobertura previdenciária necessária ao bem-estar social do conjunto da sociedade.

Afora isso, a filiação compulsória do segurado aos sistemas de previdência pública reduziria a incerteza que ocorre quando cada pessoa tem de cuidar isoladamente de seu próprio futuro. A intervenção do governo pode diminuir a dificuldade do segurado em preparar a aposentadoria futura, por minimizar a incerteza sobre o ritmo da atividade econômica, o rumo dos resultados dos investimentos, os índices de inflação e a duração da vida de cada um.

Outro argumento, na mesma linha de pensamento de Thompson (2000), é que os programas previdenciários (contributivos ou não) destinados a favorecer as pessoas que ganham pouco durante a vida são um dos mecanismos a sociedade pode utilizar para alterar a distribuição de renda resultante do mercado. Comparado aos programas assistenciais, um programa previdenciário tem a vantagem de prover a renda de uma maneira que preserve a dignidade dos idosos, o que socialmente é mais aceitável.

Para se atingir este último escopo, como se proclama em texto de Bobbio, é recomendável que o próprio Estado faça discriminações, no sentido de privilegiar os menos favorecidos, pois "desse modo, uma desigualdade torna-se um instrumento de igualdade pelo simples motivo de que corrige uma desigualdade anterior: a nova igualdade é o resultado da equiparação de duas desigualdades" (apud Castro; Lazzari, 2008, p. 51).

\subsection{Razão jurídica}

A razão jurídica baseia-se na circunstância de que, na atualidade, os princípios orientadores do direito individual dos cidadãos a determinada forma de segurança social integram os ordenamentos jurídicos tanto na esfera nacional, quanto na internacional. 
Portanto, constitui um erro de análise, porque distorce a realidade objetiva dos fatos, a perspectiva puramente economicista da segurança social que faz tábua rasa do patrimônio jurídico existente em matéria de proteção social. A influência da razão jurídica nos direitos internos é incontestável, pois se manifesta nos âmbitos das constituições ou leis fundamentais dos diferentes países, no domínio de suas leis gerais e, finalmente, no plano de sua legislação concreta, cuja amplitude chega a dar origem a verdadeiros "códigos de segurança social”.

Castro e Lazzari (2008, p. 48) constatam que

(...) uma das características do Estado Contemporâneo é a inclusão, no rol de direitos fundamentais, dos chamados Direitos Sociais, de proteção quanto às vicissitude causadoras de uma perda, ou uma diminuição, da condição de subsistência, a partir da concepção de um Estado intervencionista, capaz de não só regular, mas também impor determinadas obrigações, com a finalidade de amparar as pessoas, tendo por objetivo garantir a todos uma vida com dignidade.

Os Direitos Sociais são considerados Direitos Fundamentais, partindo-se da concepção de que o Estado não deve se manter inerte diante dos problemas decorrentes das desigualdades causadas pela conjuntura econômica e social. (Castro; Lazzari, 2008, p. 48)

\subsection{Razão política}

A razão política reside no fato de que a intervenção dos órgãos do poder político na garantia de direitos sociais dá origem a compromissos e expectativas que atravessam transversalmente as sociedades modernas.

A profundidade e a gravidade deste vínculo político resultam não só da espécie de contrato social estabelecido entre os cidadãos e as forças políticas, mas também de um acordo entre gerações, que constitui a base dos regimes de repartição financeira dos sistemas previdenciários, cujos encargos com as prestações pecuniárias em favor da população idosa são assegurados pela população economicamente ativa. Esse pacto geracional cria a expectativa de direitos de que a geração economicamente ativa de hoje terá, no futuro, os seus benefícios custeados pelos trabalhadores que os procederem. 


\section{Surgimento da Previdência Social como obrigação do Estado}

\subsection{Primórdios da proteção social}

Celso Barroso Leite (1986, p. 20, apud Netto, 2002, p. 140) define proteção social como

O conjunto de medidas de caráter social destinadas a atender a certas necessidades essenciais dos indivíduos; mais especificamente, às necessidade individuais que, não atendidas, repercutem sobre os demais indivíduos e em última análise sobre a Sociedade.

Nesse sentido, não seria absurdo afirmar que a proteção social, ainda que muito rudimentar, desordenada, empírica e fragmentada sempre existiu, na medida em que se reconhece a existência do homem como ser social que mutuamente se auxilia, desde as eras mais remotas.

Num primeiro estágio, a proteção social vinculava-se tão somente a simples tolerância da convivência em grupo e, quando muito, na estocagem de alimentos para serem consumidos no futuro. Isso, porém, evidencia a preocupação do homem com o seu bem-estar vindouro.

Mas isso pouco se assemelha aos modelos de seguridade social da contemporaneidade. Russomano (1988) salienta que o início da previdência social não pode se confundir com o momento em que o homem começou a guardar alimento para o dia seguinte, na medida em que o pano de fundo para o seu surgimento foi o sentimento universal de solidariedade entre os homens, ante as pungentes aflições de alguns e a generosa sensibilidade de muitos. Assim, não se pode investir demasiadamente na tese da existência de mecanismos de proteção social das sociedades primitivas, mas apenas frisar que, mesmo nos idos mais remotos das civilizações, a preocupação com o bem-estar do presente e do futuro rondava os círculos sociais.

Com efeito, pode-se afirmar que dos tempos mais remotos da evolução da sociedade humana até o final do século XVI pouco se evoluiu em matéria de proteção social. De toda sorte, depois da consolidação da Igreja Católica, ganhou relevo a influência religiosa na 
conduta das pessoas naturais e do próprio Estado, vez que à época a Igreja influenciava de maneira decisiva as manifestações políticas.

No entanto, não se pode desprezar o fato de que ao componente religioso sobrepujavam os interesses estatais, voltados à manutenção de bases estruturais de exploração e opressão, até porque a caridade religiosa tinha como base apenas o dever moral. Aliava-se, assim, por comodidade e conveniência, o dever caridoso do católico para com os incapacitados e indigentes com o interesse dos Estados absolutistas em se manter intactos os fundamentos dos abusos e da exploração praticados.

A assistência social pública aos carentes e indigentes, ganhou status jurídico, na Europa Ocidental, com a edição de leis de caráter nitidamente assistencial, no decorrer do século XVII. A chamada Lei dos Pobres Londrina, de 1601, que instituía a contribuição obrigatória par fins sociais, foi precursora da legislação editada com intuito assistencial.

Conforme anota Russomano (1988), a importância de tal marco legislativo na história da proteção social reside na atribuição do dever do Estado em gerir a organização e a efetivação dos serviços de assistência social. Entretanto, naquela época, estava-se "muito longe da existência de um verdadeiro regime de Previdência Social, que deve ser considerado como a organização administrativa que - sob direta responsabilidade do Estado - assegura aos beneficiários as prestações que cobrem os riscos inerentes às atividades profissionais ou econômicas" (p. 07).

Não é por outra razão que Russomano (1988, p. 06) afirma que

Essa "oficialização da caridade" - como foi dito, certa vez - tem importância excepcional: colocou o Estado na posição de órgão prestador de assistência àqueles que - por idade, saúde e deficiência congênita ou adquirida - não tenham meios de garantir sua própria subsistência. A assistência oficial e pública, prestada através de órgãos especiais do Estado, é o marco da institucionalização do sistema de seguros privados e do mutualismo em entidades administrativas. [(...)] Hoje compreende-se que nesse passo estava implícita a investida de nossa época, no sentido de entender os benefícios e serviços da Previdência Social à totalidade dos integrantes da comunidade nacional, a expensas, exclusivamente, do Estado, e não apenas aos associados inscritos nas entidades de Previdência Social. Dessa forma, podemos concluir dizendo: naquele momento distante, no princípio do século XVII, começou, na verdade, a história da Previdência Social. 
Não obstante terem sido voltadas para o campo da assistência social pública, as leis editadas no século XVII representam um marco expressivo na evolução da Previdência Social, cuja concreção decorre também da influência religiosa, que não se limitou àquele período, haja vista ter lastreado sua doutrina sobre as evoluções mais recentes dos séculos XIX e XX.

\subsection{Estado Liberal}

O tardio surgimento da Previdência Social como modalidade de proteção social assegurada pelo Estado é atribuído ao pensamento liberal predominante no período précapitalista ou pré-industrial.

Para o Estado Liberal, o valor da liberdade confundia-se com a prevalência do interesse individual e o resguardo da personalidade humana, relegando-se a quase nada a coação estatal. Era a idéia do Estado não intervencionista, cujo pressuposto fundamental assentava-se no entendimento de que o bem-estar coletivo podia ser atingido com a menor presença possível do Estado, a quem competiria precipuamente assegurar as liberdades políticas negativas e os direitos civis básicos de uma minoria.

No discurso liberal clássico, o indivíduo deveria satisfazer suas necessidades nos limites do mercado, ou seja, a provisão de todos os bens e serviços necessários ao bem-estar individual não se daria, em nenhuma hipótese, com a intervenção estatal. O Estado garantiria apenas o direito à propriedade, o cumprimento dos contratos firmados entre os indivíduos e zelava pela manutenção da ordem necessária ao pleno desenvolvimento das atividades econômicas da burguesia.

Constitui afirmação máxima do laissez-faire aquela que consagra o ideal de que os mais "capazes" e "eficientes" conseguem prosperar num sistema econômico de "concorrência perfeita". O bem-estar, neste sentido, seria então identificado com a riqueza que, por sua vez, dependeria do esforço e habilidade individuais. Por conseguinte, aqueles que não se adequassem satisfatoriamente às "leis de mercado" e não fossem, de alguma forma, incorporados ao mercado de trabalho, seriam considerados "vagabundos" e "incapazes". Este 
fenômeno social caracteriza uma noção de "naturalização" das condições sócio-econômicas, uma dada naturalização da exclusão social, esta entendida como constituinte de um processo de formação natural das sociedades, não sendo derivada das condições históricas e estruturais do modo de produção.

O ideal liberal de bem-estar identifica a satisfação das necessidades individuais e sociais pela esfera do consumo, através da noção utilitarista de satisfação dos desejos e preferências individuais pela "livre escolha" num sistema de mercado e, ainda, num contexto social que pressupõe igualdade de condições e uma concorrência perfeita entre os agentes econômicos.

(...) a desigualdade social como algo histórico-estrutural revela que é parte da dinâmica dialética da história, ou seja, a mudança histórica é característica da estrutura, não de meras conjunturas; o conflito social move a história (DEMO, 1997, apud Torres, 2006, p. 35).

Portanto, para essa escola do pensamento econômico (o liberalismo), o bem-estar é reduzido a uma questão puramente individual, baseada numa perspectiva ideológica de que a "livre concorrência" e as "leis naturais do mercado" pudessem, de fato, resolver todos os problemas de ordem econômica, política e social:

Toda teoria liberal do bem-estar está baseada no mercado e no consumo. É no mercado que os indivíduos, átomos sociais, devem procurar satisfazer suas preferências, seus gostos (...) assim, supõe-se que todos os bens que "atendam" às "necessidades básicas" do homem estejam no mercado: alimentação, moradia, roupa, lazer, educação (em parte), saúde (em parte), transporte (em parte) (Faleiros, 2000, p. 17).

Com o advento da grande crise estrutural do capitalismo que se materializou na queda drástica da Bolsa de Nova Iorque em 1929, outra concepção de economia política emergiria como justificativa para o processo de intervenção estatal nas relações sociais, ou nas relações de produção capitalistas, consagrando o argumento da necessidade da intervenção do setor público no sistema econômico, sobretudo a teoria macroeconômica keynesiana publicada originalmente em 1936.

\subsection{Estado Social}

A admissão de que a proteção social é pressuposto para o desenvolvimento digno do ser humano e que, como tal, deve ser organizada e desenvolvida pelo Estado, é uma conquista 
cuja sociedade demorou longos anos para alcançar e está inserida na caracterização do Estado de Direito como Estado social, submetido à socialização e à democracia, e comprometido com a garantia da dignidade da pessoa humana e com a realização dos direitos fundamentais.

A concepção do Estado como social, cujo marco inicial é fixado no período subseqüente a primeira grande guerra, permitirá dar especial importância para técnicas de proteção de caráter preventivo e solidário quanto aos riscos individuais. É nessa perspectiva que será determinado, como afirma Rosanvallon (1997), a substituição da incerteza da providência religiosa pela certeza da providência estatal. Ainda que as práticas de proteção dissociadas do Estado e o mero assistencialismo estatal tenham fracassado na realização de seus fins, eis que provaram ser insuficientes e demasiadamente limitadas, as mesmas não deixarão de existir, pois continuarão absorvendo demandas que apresentem o perfil da beneficência e da caridade. $O$ principal ator na conquista de eficiência nas políticas sociais passa a ser idealizado na figura do Estado, por meio do desenvolvimento de um sistema estatal de proteção social que antecipe soluções para acontecimentos capazes de colocar o indivíduo em situação de vulnerabilidade.

Essa nova postura de proteção social assumida pelo Estado, ao mesmo tempo em que busca acomodar uma nova realidade, traz a marca das mudanças provocadas pelo desenvolvimento científico e econômico, pelo surgimento e pela expansão da indústria e do trabalho livre e assalariado e pela maciça e precária concentração da população nos centros urbanos. A partir de então, segundo Castel (2003, p. 464), resta claro que

\footnotetext{
(...) a oscilação entre revolução e reforma, que sempre percorreu o movimento operário, vem fixar-se com insistência cada vez maior no segundo pólo, e a clivagem entre eles e nós deixa de alimentar um imaginário da mudança radical. Nesta medida, a possibilidade da revolução abre espaço para uma nova realidade, a realidade da negociação e da mediação, em que a tormentosa relação entre capital e trabalho é apaziguada por meio do exercício de concessões que permitirão o desenvolvimento de um compromisso social.
}

Sobre a instituição do livre acesso ao trabalho, Castel (p. 44-45) observa que se trata de uma revolução jurídica, tão importante quanto a revolução industrial de que, aliás, é a contrapartida.

(...) Mas essa revolução é igualmente decisiva em relação ao que segue. É ela que reintroduz a questão social sobre bases absolutamente novas no início do século XIX. Sob o reino da tutelas, a condição de assalariado asfixiava-se. Sob o regime do 
contrato, ela se desenvolve, mas, paradoxalmente, a condição operária se torna frágil ao mesmo tempo em que se liberta. Descobre-se, então, que a liberdade sem proteção pode levar a pior servidão: a da necessidade. (...) O Estado social foi construído como uma resposta a tal situação. Acreditou poder esconjurar-lhe os riscos, tecendo, em torno da relação de trabalho, sólidos sistemas de garantias.

Por conta dessa realidade, pode-se dizer que a eclosão das políticas sociais modernas é resultado da convergência de diversas forças e atores que compunham o cenário no qual a sociedade da época estava organizada, o que não significa, contudo, comunhão de interesses pelos atores envolvidos. Nesse sentido, Godinho Delgado (2001, p. 38) assevera:

a dinâmica societária que conduziu ao aparecimento das políticas sociais modernas e do Estado de Bem-Estar Social associa-se, por um lado, aos processos de interdependência que derivam do desenvolvimento da vida urbana moderna e, por outro, da interação, o conflito e o entendimento entre determinados atores da sociedade capitalista.

Nesta perspectiva o desenvolvimento de um sistema de proteção social estatal ancorado na busca da realização de justiça social, dentro de um contexto de organização social capitalista, demonstra a compreensão de que, se o Estado, e a sociedade como um todo, não dispensarem atenção para a realização das necessidades individuais dos cidadãos, acabarão sofrendo os reflexos da ausência dessa proteção, uma vez que segundo Leite (2002, p. 21, apud Ramos, 2006, p. 36),

(...) as necessidades essências de cada indivíduo, a que a sociedade deve atender, tornam-se na realidade necessidades sociais, pois quando não são atendidas repercutem sobre os demais indivíduos e sobre a sociedade inteira. Esta, então, prepara-se com antecedência para, na medida do possível, fazer de maneira racional o que teria de acabar fazendo de improviso, desordenadamente, em condições desfavoráveis.

Observe-se, ainda, que as novas tarefas assumidas pelo Estado e pela sociedade são fortemente fundamentadas na necessidade urgente de combater os efeitos perversos oriundos da modificação no processo produtivo que marca o advento da Revolução Industrial e conduz para a imposição de uma drástica limitação econômica aos trabalhadores não-proprietários.

No período pós-industrial, atribui-se ao Chanceler Otto Von Bismarck a responsabilidade pelo nascimento da Previdência Social, com a edição da lei de seguros sociais em 1883, não que antes não tenha havido qualquer outra norma de natureza previdenciária. Outras normas precederam àquela instituída por Bismarck, como a chamada 
lei das minas de 1842 na Inglaterra, dentre outras leis ainda que nenhuma delas tenha tido o alcance e amplitude da lei de seguros sociais do estadista alemão.

Institui-se, de início, o seguro-doença, para, logo depois, em 1884, abarcar o seguro contra acidente do trabalho e, em 1889, o seguro-invalidez e a velhice. O custeio das prestações, por seu turno, tinha sustentação nas contribuições dos empregados, empregadores e do Estado.

A respeito do seguro social inaugurado em sua gestão, são as palavras de Bismarck citada por Pereira Junior (2005, p. 08):

\begin{abstract}
Consideramos ser de nosso dever imperial pedir de novo ao Reichstag que tome a peito a sorte dos operários. Nós poderíamos encarar com uma satisfação muito mais completa todas as obras que nosso governo pôde até agora realizar, com a ajuda visível de Deus, se pudéssemos ter a certeza de legar à Pátria uma garantia nova e durável, que assegure paz interna e desse aos que sofrem a assistência a que têm direito. É nesse sentido que está sendo preparado um projeto de lei sobre o seguro dos operários contra os acidentes do trabalho. Esse projeto será completo por outro, cujo fim será organizar, de modo uniforme, as caixas de socorro para o caso de moléstia. Porém, também aqueles que a idade, a invalidez tornaram incapazes de prover ao ganho quotidiano, têm direito a maior solicitude do que a que lhe tem, até aqui, dado a sociedade. Achar meios e modos de tornar efetiva esse solicitude é, certamente, tarefa difícil mas, ao mesmo tempo, uma das mais elevadas e um estado fundado sobre bases morais da vida cristã".
\end{abstract}

Percebe-se da passagem acima que, ao mencionar a "paz interna" como um dos escopos do projeto de lei sobre o seguro dos operários, a intenção de Bismarck em ampliar o espectro de proteção previdenciária aos trabalhadores, tendo em mente evitar os riscos de uma revolução.

O êxito do plano de seguro social de Bismarck levou que essa tendência se espalhasse pelos demais países da Europa, protegendo principalmente os trabalhadores, sem que se descurasse da proteção fornecida pelos mecanismos de assistência social aos demais atores sociais.

Em outros países, como a Itália, em 1883, e a França, em 1898, adotaram-se inicialmente sistemas mais modestos, visando tão-somente proteger os trabalhadores contra acidentes do trabalho e doenças profissionais, a partir da transposição das regras de 
responsabilidade civil. Na Inglaterra, o Workmen's Compensation Act de 1897 consagrou a responsabilidade do empregador por infortúnios, independentemente de culpa.

Além disso, mais uma vez, os fundamentos cristãos pesaram a favor da ampliação da proteção social. A encíclica Rerum Novarum do Papa Leão XIII analisou a situação dos pobres e trabalhadores nos países industrializados, estabelecendo um conjunto de princípios da doutrina social da Igreja Católica.

A formação do seguro social cujo ineditismo é atribuído ao Chanceler Bismarck, sem dúvida, avançou significativamente e sucedeu às congregações de cunho mutualista que, por seu turno, já haviam superado o estágio inicial da mera assistência social pública.

Nas associações de natureza mutualista, a vinculação dos associados dava-se de forma voluntária, e de finalidade voltada para a prestação de socorro recíproco. O seguro social, por sua vez, exigia a vinculação obrigatória, com a compulsória filiação de um grupo de trabalhadores ou certa camada da população, verificando-se maior abrangência na proteção aos trabalhadores expostos aos enormes riscos decorrentes da recente realidade ofertada pela revolução industrial.

Salienta, entretanto, Pereira Junior (2005), que a noção de seguro social não estava inspirada no desejo de garantir aos indivíduos a proteção contra os riscos comuns da vida. Assim, justamente em virtude da inexistência de uma formulação teórica e dos motivos que lhe deram origem, o seguro social foi considerado apenas como um método destinado a atender a estrutura econômica vigente, em face da propensa incapacidade gerada pela vicissitude da vida a que está sujeita a grande massa trabalhadora, totalmente desprovida de recursos. Na realidade, o seguro social nasceu atrelado às concepções do seguro de direito privado.

Atrelava-se o seguro social a um risco único representado pela eventual impossibilidade de o trabalhador perceber seu salário, por força da ocorrência do infortúnio. E em razão dessa vinculação estrita da noção de seguro social, apenas a proteção ao risco único do trabalhador, conduziu-se a um movimento global para a formulação de um conceito voltado à cobertura universal, a fim de assegurar o bem-estar presente e futuro dos membros de toda a sociedade. 
O contexto histórico, os atores envolvidos e a maneira como ocorreu o desenvolvimento das políticas de proteção social demonstram tratar-se de um competente arranjo que conseguiu acomodar as conseqüências oriundas da alteração sofrida pelo método de produção e divisão do trabalho, que inaugurava uma nova forma de organização social, mantendo a sociedade dentro dos trilhos do capitalismo.

Sob a ótica de Godinho Delgado (2001), essa leitura permite constatar que as políticas sociais modernas surgem como respostas, desenvolvidas no interior das sociedades nacionais e através do Estado Nacional, aos dilemas sociais decorrentes da operação do mercado capitalista. $\mathrm{O}$ momento que antecede a instalação dessas modernas técnicas de proteção reflete o momento histórico no qual é identificada a existência de uma significativa fratura social, que pode desencadear um processo de perturbação à manutenção da ordem social, uma vez que a Revolução Soviética de outubro de 1917 já acenava ao mundo uma alternativa possível ao capitalismo.

Sobre a importância que a Revolução de Outubro representou para a história do século XX, Hobsbawm (1995, p. 62 e 89) refere que

\begin{abstract}
a mesma produziu de longe o mais formidável movimento revolucionário organizado na história moderna. (...) se revelou a salvadora do capitalismo liberal, tanto possibilitando ao Ocidente ganhar a Segunda Guerra Mundial contra a Alemanha de Hitler quanto fornecendo o incentivo para o capitalismo se reformar, e também paradoxalmente graças à aparente imunidade da União soviética à Grande Depressão, o incentivo a abandonar a crença na ortodoxia do livre mercado.
\end{abstract}

Esse quadro de tensão e fratura social à época vivenciado, determina, segundo Castel (2003, p. 345-346), a abertura

\begin{abstract}
de um espaço de mediações que dá um novo sentido ao social: não mais dissolver os conflitos de interesse pelo gerenciamento moral nem subverter a sociedade pela violência revolucionária, mas negociar compromissos entre posições diferentes, superar o moralismo dos filantropos e evitar o socialismo dos distributivistas . [(...)] $\mathrm{O}$ advento da propriedade social representa uma das conquistas decisivas que se deve a modernidade e que reelabora em novos termos o conflito secular entre patrimônio e trabalho.
\end{abstract}

A aproximação entre Estado e sociedade, fundamento da caracterização do Estado de Direito como Estado social, associada às restrições impostas ao exercício do direito privado, e 
a inserção dos direitos sociais nas Constituições dos Estados, atribui ao Estado a responsabilidade pela organização da grande teia social que o envolve.

Sobre os documentos históricos que marcam esta fase destacam-se a Constituição mexicana de 1917, seguido pelo Tratado de Versalhes, que pôs fim a Primeira Grande Guerra, a criação da Organização Internacional do Trabalho (OIT) e a Constituição de Weimar², acontecimentos estes datados de 1919 e referido na doutrina, entre outros, por Rocha (2004).

Observa-se, assim, que o período que segue a Primeira Guerra Mundial é marcado por significativos acontecimentos políticos e econômicos, os quais inauguram o desenvolvimento de uma política econômica intervencionista e a regulação das políticas sociais, evidenciando a configuração do Estado Social, atingindo o seu melhor momento somente após a Segunda Grande Guerra, quando então o Estado, coagido pela pressão das massas, confere, no Estado constitucional ou fora deste, os direitos do trabalho, da previdência, da educação, intervém na economia como distribuidor, dita o salário, manipula a moeda, regula os preços, combate o desemprego, controla as profissões, compra a produção, financia as exportações, concede crédito, institui comissões de abastecimento, provê necessidades individuais, enfrenta crises econômicas, enfim, estende sua influência a quase todos os domínios que dantes pertenciam, em grande parte, à área da iniciativa individual, nesse instante o Estado passa a receber a denominação de Estado social.

No percurso rumo à concretização do Estado social os seguros sociais obrigatórios inaugurados na Alemanha representam um ideal que, além de orientar o continente europeu após o término da Primeira Guerra, avança para outras fronteiras impondo-se como um eficaz modelo de proteção estatal. À medida que este novo sistema de seguro, que segundo Castel (2003) é creditado à promoção da propriedade de transferência, expande-se, contando com a ajuda fundamental da OIT, vai também agregando novos elementos, passando por adaptações e reformulações, o que permite a sua adequação a realidades de diferentes países e continentes. É, contudo, em um momento de grave crise econômica que, frente à necessidade urgente de acomodar as tensões sociais, será dado início ao desenvolvimento de um modelo de proteção social que evolui do sistema de seguro social para a idéia de Seguridade Social.

\footnotetext{
${ }^{2}$ A respeito da Constituição de Weimar é importante referir que ao inserir em seu texto os preceitos do seguro social, permite que essa técnica de proteção social, que já vinha sendo experimentada na Europa, conquiste grande visibilidade, já que esta Constituição acabou por servir de inspiração para tantas outras nações.
} 
Com efeito, a crise decorrente da quebra da bolsa de valores registrada em 1929 encerra a segunda década do século XX sob um cenário de depressão econômica. $\mathrm{O}$ caminho para a superação dessa turbulência econômica, responsável pela instalação de um período de desaquecimento da economia e de uma grande onda de desemprego, traz como conseqüência a falta de condição para manter a subsistência própria e da família de grande parte da população, exigindo uma atitude estatal que ultrapassa a seara econômica e invade o social.

Sobre esse período da história da humanidade Hobsbawm (1995, p. 97) afirma que

(...) a consequiência básica da Depressão foi o desemprego em escala inimaginável e sem precedentes, e por mais tempo que do que qualquer um já experimentara. [(...)] O que tornava a situação mais dramática era que a previdência pública na forma de seguro social, inclusive auxílio desemprego, ou não existia, como nos EUA, ou, pelos padrões de fins do século XX, era parca, sobretudo para os desempregados a longo prazo.

$\mathrm{Na}$ tentativa de corrigir os abalos provocados por esta crise os Estados Unidos, sob o comando de Franklin Roosevelt, lançam a política econômica do New Deal, que busca reorientar a economia e as políticas sociais. É neste contexto que em 14 de agosto de 1935 os Estados Unidos lançam a Social Security $A c t^{3}$, que institui a Seguridade Social em substituição à técnica do seguro social.

Neste momento o Estado americano começa a implantar um sistema que engloba proteção previdenciária e assistencial, bem como ultrapassa a fronteira que limitava a proteção à categoria dos trabalhadores, estendendo-a à população em geral. Observa-se que essa nova política americana apenas sinaliza na construção do ideal de Seguridade Social, já que aliada ao fato de não ter sido implantada em sua totalidade, também não incluía a saúde entre as políticas de atendimento estatal, o que segundo Godinho Delgado (2001) determinou a constituição de um Estado de Bem-Estar Social pequeno, residual em diversos aspectos e fundamentalmente inconcluso.

\footnotetext{
3 Explica Godinho Delgado (2001, p. 70) que essa Lei estabelecia um regime público de aposentadoria sustentado pela contribuição de empregadores e empregados, em cerca de $1 \%$ sobre os salários, com benefícios concedidos conforme os rendimentos auferidos no mercado, sob gestão estatal. Ainda sob o New Deal seria instituído o auxílio para os cegos e estendida a legislação de 1935 às viúvas e incapacitados para o trabalho. Em 1935 foi, ainda, definida a prerrogativa dos estados para legislar sobre o seguro-desemprego e administrar os programas correspondentes, embora se orientando por padrões mínimos fixados em lei federal.
} 
Analisa ainda Godinho Delgado (2001) que a nova política americana corresponde ao modelo liberal-residual ${ }^{4}$, que conta com significativa participação da iniciativa privada e trabalha com dinâmica de característica assistencialista no deferimento dos benefícios. Esse modelo guarda ligação com o modelo corporativo desenvolvido na Alemanha, já que utiliza a sistemática do seguro social e do regime de capitalização.

A compreensão quanto à necessidade da implantação de um modelo público e efetivamente universal, que garanta o mínimo necessário para a manutenção da subsistência do indivíduo e da sua família nos momentos de tensão e fragilidade, só será conquistado após o advento da Segunda Guerra Mundial. Sobre este momento especial da história Godinho Delgado (2001, p. 73) relata que

\begin{abstract}
a guerra aparece, pois, como um evento crítico que impulsiona a formação dos Estados de Bem-Estar Social, seja porque a mobilização militar acentua a coesão no interior das sociedades nacionais, seja porque reconcilia os empresários com a intervenção estatal, favorecendo a constituição do wartine triangle, envolvendo o Estado, os empresários e os trabalhadores industriais, seja em função do novo equilíbrio de poder que emerge após seu final. A expansão do campo socialista parecia tornar mais vulneráveis as sociedades capitalistas, caso não atendessem as demandas de reforma social que encontravam eco no movimento operário dos países ocidentais.
\end{abstract}

É no pós-guerra que se encontrou o momento propício para a implantação do modelo de Seguridade Social público, obrigatório e universal, que traça sua caracterização no contexto de uma perspectiva solidária e inclusiva, visando à redução das desigualdades por meio da utilização de mecanismos que permitam uma justa distribuição de renda e bem-estar geral e que agregue a seus fins o desenvolvimento de políticas públicas na área da saúde, libertando-se dos limites da proteção previdenciária e assistencial. As políticas desenvolvidas nesse período, especialmente a instauração da Seguridade Social em 1945, retratam, segundo Castel (2003), uma etapa decisiva da proteção da condição de assalariado no prolongamento do desenvolvimento da propriedade de transferência.

O modelo de Previdência Social que vinculava a obrigatoriedade de inclusão do indivíduo nos programas de proteção previdenciária ao exercício de atividade profissional, especialmente sob o formato de relação de emprego, começou a ser superado no início da década de 1940. Esta superação buscou construir um novo formato de proteção social que

\footnotetext{
${ }^{4}$ O Capítulo II deste estudo trata especificamente dos modelos de proteção social, entre os quais o liberalresidual e o corporativo citados neste parágrafo.
} 
impediu o desenvolvimento de nichos sociais protegidos, como acontecia com o trabalhador empregado, ao passo que grande parte dos trabalhadores era excluída desta proteção.

A construção desse novo modelo de proteção é iniciada em 1941 na Inglaterra, quando uma comissão presidida por William Beveridge desenvolve um plano de Seguridade Social que visa dar cobertura para a universalidade dos indivíduos, excluindo a exigência de qualquer espécie de pré-condição para a inserção no grupo dos protegidos. O modelo beveridgeano é também responsável pela incorporação de políticas públicas desenvolvidas na área da saúde, combate ao desemprego, atendimento familiar, entre outras, nos limites de atuação da Seguridade Social.

Os planos Beveridge, como se tem chamado os relatórios apresentados pela comissão formada pelo governo britânico e presidida pelo Sir William Beveridge, teriam sido influenciados pelas idéias do economista inglês John Maynard Keynes, de quem aquele tinha sido colaborador (Castro; Lazzari, 2008), o qual pregava, em síntese, o crescimento econômico num contexto de intervenção estatal no sentido de melhor distribuir - ou até mesmo redistribuir - a renda nacional.

Os dois planos partiram do pressuposto de que se devia assegurar a eficaz proteção ao povo, não se limitando sua abrangência apenas aos trabalhadores cujas prestações estavam atreladas a excessivos critérios de concessão.

Para Godinho Delgado (2001), este novo modelo de organização e articulação da proteção social corresponde ao modelo público universalista, que exige significativa atuação do Estado e cujo financiamento conta com importante parcela de recursos orçamentários.

Quanto aos benefícios, sua concessão leva em consideração a noção de mínimo vital, no caso das aposentadorias e pensões, cujo sistema é estruturado basicamente segundo os padrões de repartição simples. Quanto aos demais serviços sociais, este modelo caracteriza-se por oferecer uma ampla teia de proteção.

Sobre o modelo desenvolvido pela comissão presidida por William Beveridge, Fortes (2005, p. 25-26) afirma tratar-se de um 
(...) programa de prosperidade política e social, mediante ingressos suficientes para que o indivíduo ficasse garantido contra a ocorrência de riscos sociais (como indigência ou impossibilidade laborativa) (...). Assim, apontava como solução, no combate à miséria, um processo de redistribuição de renda, calcado nas necessidades da família. A proteção social, nesta ótica, não mais se restringe aos seguros sociais dos trabalhadores, abarcando também prestações de assistência social, serviços de saúde, atendimento familiar, políticas de pleno emprego, entre outras medidas.

O modelo beveridgeano baseado na conclusão de que o combate à miséria requeria uma dupla distribuição das rendas: pelos seguros sociais e pelas necessidades da família, defende a necessidade de o Estado capitalista assumir franca regulação estratégica, o que é observado por Netto (2002, p. 32-33) ao afirmar que

(...) foi efetivamente a doutrina keynesiana (de John Maynard Keynes) que forneceu as bases para a implantação inovadora da mais durável e prestigiada forma de regulação da atividade econômica que o sistema capitalista conheceu. Divergindo da teoria econômica clássica, defensora da auto-regulação do mercado e, portanto, da idéia de que havia uma mão invisível assegurando o equilíbrio entre oferta e procura, Keynes pregava o contrário. Para ele, o governo deveria promover a construção maciça de obras públicas, a fim de gerar dispêndios capazes de erradicar o desemprego e, de modo geral, manter aquecida a demanda agregada (procura global pelos produtos postos à venda) para garantir o pleno emprego. Isso deu margem a ampla intervenção estatal tanto na esfera econômica como na esfera social. A doutrina keynesiana estimulou a criação de medidas macroeconômicas, que incluíam: a regulação do mercado; a formação e controle dos preços; a emissão de moedas; a imposição de condições contratuais; a distribuição de renda; o investimento público; o combate à pobreza, etc.

Frente a um panorama de crise e tensão social, o Estado moderno optou pela admissão da estratégia keynesiana, cuja fórmula buscava enfrentar os problemas existentes por meio de uma reformulação na técnica de organização capitalista, já que o modelo liberal de inspiração individualista que enaltecia a livre regulação do mercado dava mostras de impotência na solução da crise.

Nesse sentido Hobsbawm (1995, p. 265) refere que

O capitalismo do pós-guerra foi inquestionavelmente, como assinala a citação de Crosland, um sistema reformado a ponto de ficar irreconhecível, ou, nas palavras do primeiro ministro britânico Harold Macmillian, uma nova versão do velho sistema. [(...)] Essencialmente, foi uma espécie de casamento entre liberalismo econômico e democracia social (ou, em termos americanos, política do New Deal rooseveltiano), com substanciais empréstimos da URSS, que fora pioneira na idéia do planejamento econômico.

A manutenção e o fortalecimento do capitalismo, por meio da adoção de novas estratégias de ação, passa pela redefinição do papel que o Estado ocupa na organização da 
sociedade e das ações que devem ser por este assumidas. Nesse sentido, para o governo o mais importante não é fazer coisas que os indivíduos já estão fazendo, e fazê-las um pouco melhor, ou um pouco pior, mas fazer aquelas coisas que atualmente deixam de ser feitas.

Nesse contexto, várias são as críticas levantadas contra a nova postura do Estado, especialmente porque, ainda que introduza mecanismos de proteção para a população em geral, não altera a matriz de produção capitalista, permitindo sua manutenção e fomentando o seu fortalecimento.

A nova perspectiva de atuação assumida pelo Estado no pós-guerra fortaleceu a sua concepção social, e a nova sistemática de proteção social, ainda que assumindo forma, estratégia e ritmo diferenciado em cada país, expande-se da Inglaterra para o resto do mundo capitalista.

Assim, a humanidade vê na implantação da Seguridade Social uma das medidas capazes de ajudar a equacionar os problemas econômicos, políticos e sociais que afligiam a sociedade daquela época.

A reforçar esta tendência, a Declaração Universal dos Direitos do Homem (1948), destaca, entre outros direitos fundamentais da pessoa humana, a proteção previdenciária. $\mathrm{O}$ art. XXV do citado diploma determinava que

\footnotetext{
"todo homem tem direito a um padrão de vida capaz de assegurar a si e a sua família saúde e bem estar social, inclusive alimentação, vestuário, habitação, cuidados médicos e os serviços sociais indispensáveis, o direito à segurança no caso de desemprego, doença, invalidez, viuvez, velhice ou outros casos de perda dos meios de subsistência em circunstâncias fora de seu controle".
}

A Organização Internacional do Trabalho (OIT), em sua Convenção no 102, aprovada em Genebra em 1952, em igual diapasão, estabelece um padrão mínimo de Seguridade Social apto a proporcionar proteção aos membros da sociedade, mediante uma série de medidas públicas contra as privações econômicas e sociais que de outra forma, derivam do desaparecimento ou em forte redução de sua subsistência como conseqüência de enfermidade, maternidade, acidente de trabalho ou enfermidade profissional, desemprego, invalidez, velhice, e também a proteção em forma de assistência médica e ajuda às famílias com filhos. 
A adequação da sistemática de proteção do seguro social ou da Previdência Social para a Seguridade Social faz com que uma nova e abrangente universalidade de indivíduos seja incluída numa rede de proteção mais forte e eficiente no combate às tensões sociais. A Seguridade Social, nessa medida, pode ser definida como um conjunto de ações públicas, desenvolvidas e articuladas pelo Estado, direcionadas à realização de proteção quanto aos acontecimentos que tendem a privar o indivíduo de uma sobrevivência digna. Insere-se, assim, entre os direitos do cidadão e os deveres do Estado, alcançando especial importância no campo das políticas sociais como um todo, o que é determinante para a consolidação e a expansão do Estado social, que nesse momento histórico é por muitos denominado de Estado de bem-estar social ou Welfare State . $^{5}$

Sobre as diferentes denominações atribuídas ao Estado, Novais (1987, p. 198 apud Ramos, 2006, p. 46) esclarece:

\begin{abstract}
Para traduzir as novas preocupações e funções do Estado no século XX tem sido proposta uma multiplicidade de designações, desde o "Estado assistencial" e "Estado-Providência" ao "Welfare State" ou "Estado de bem-estar", mas também "Estado de Partidos", "Estado de Associações" e "Estado administrativo". Em qualquer destas expressões é possível notar pontos comuns ou mesmo identidades fundamentais com a idéia que explicitamos sob a forma de estado social.
\end{abstract}

A despeito da designação adotada, o Estado social surge como o conceito mais apto para exprimir, com toda a extensão salientada, a natureza específica do novo tipo de relação entre Estado, cidadão e sociedade.

Nesta medida, a partir da década de 1940, parte do mundo presenciou um Estado de maior expressão social, que passou a intervir em áreas estratégicas para garantir o bem-estar geral dos indivíduos e a realização da dignidade do ser humano. Trata-se de um período no qual as políticas atreladas à Seguridade Social ganham destaque e a Previdência Social, principal veículo deste sistema, resta fortalecida especialmente pela sua universalização e pela inclusão da solidariedade entre os participantes, valor este que ainda hoje se apresenta como suporte e referência daquilo que se entende por previdência pública.

\footnotetext{
${ }^{5}$ Esping-Andersen (1991) chama atenção para o fato de, historicamente, ter-se atribuído o status de welfare states para modelos de Estado com sistema de proteção social modestos ou, nas suas palavras, tipo padrão . Para o autor o que vai determinar o genuíno welfare state é a existência de um sistema que garante realização dos direitos sociais com base na cidadania, que determine uma desmercadorização dos indivíduos perante o mercado. Nesse sentido é apenas no início da década de 70 que alguns Estados adquirem o status de welfare state. .
} 
Nesse sentido a solidariedade, não advém apenas da cotização dos indivíduos que poderão ser beneficiados pela proteção, mas do fato de que todos, ou seja, beneficiários, empresas, sociedade em geral e o próprio Estado participam, direta ou indiretamente, do financiamento desta forma de proteção social, apresenta-se como a viga mestra do modelo previdenciário público ancorado no regime de repartição, desenvolvido no decorrer do século $\mathrm{XX}$.

Segundo este modelo, a proteção social previdenciária determina a realização de um pacto, pelo qual os trabalhadores, o Estado e a sociedade organizam-se solidariamente para garantir o pagamento de prestações e serviços para os trabalhadores que se enquadrem em determinas contingências da vida, programadas, a exemplo da aposentadoria por idade, ou não programadas, como a invalidez decorrente de acidente do trabalho ou de qualquer natureza. A eficiência do regime estaria justamente no fato de que não apenas os indivíduos mais prudentes, mas também aqueles indivíduos menos precavidos, por força da obrigatoriedade de participação, asseguram o custeio do sistema.

A inclusão da solidariedade como elemento da moderna política de proteção social, embora trate de uma solidariedade forçada, permite a amenização dos efeitos da injusta distribuição de renda imposta pelo modelo capitalista de organização social. Ocorre que, o despertar do ser humano e, mais especificamente do trabalhador já incluso num regime obrigatório de proteção, para o exercício da solidariedade, em detrimento do modelo de capitalização, não é tarefa fácil, pois cada categoria social é dotada de singularidades, e como tal tende a exercer a defesa de interesses próprios, deixando para um segundo momento o exercício da solidariedade para com os demais grupos sociais. Ao Estado caberá então a árdua tarefa de gestão da solidariedade, verdadeira protagonista da união das diferentes forças que compõe o quadro social.

O apogeu do modelo de Estado social, no qual a prosperidade econômica se fazia acompanhar de importantes transformações sociais, que se convencionou denominar anos dourados do capitalismo ${ }^{6}$, permitiu para muitos acreditar na construção de uma sociedade livre de desigualdades e privações. Contudo, ainda no decorrer do século XX, um estágio de

\footnotetext{
${ }^{6}$ Segundo Hobsbawm (1995) trata-se de uma fase excepcional da história do capitalismo nos países desenvolvidos denominada de anos de ouro do capitalismo, ou os trinta anos gloriosos dos franceses ou, ainda, a Era de Ouro de um quarto de século dos anglo-americanos, em que a difusão do padrão de industrialização norte-americano é combinada com o registro de elevadas taxas de crescimento e estabilização monetária.
} 
esgotamento deu início à crise do Estado social manifestada de forma contundente a partir dos anos 1970, quando o declínio do crescimento econômico determinou a relativização e até mesmo o abandono de alguns compromissos sociais. Nesse momento o Estado de bem-estar, cujo sentido literal é traduzido por Hobsbawm (1995,) como Estados em que os gastos com a Seguridade Social manutenção de renda, assistência, educação se tornaram a maior parte dos gastos públicos totais, passa a enfrentar o desafio da sua manutenção sob a perspectiva de uma nova realidade.

\title{
3. Considerações sobre a origem da proteção previdenciária estatal no Brasil
}

Não se apartando da trajetória acima descrita, quanto à evolução histórica do sistema de previdência brasileiro escreve Santos (1987, p. 13 e 14) que

\begin{abstract}
"o histórico da interferência governamental na regulação das relações sociais no Brasil não se afasta do padrão revelado pela experiência de outros países. Após o predomínio incontestável da ideologia capitalista mercantil, que fazia de todas as relações sociais contratos livremente ajustados entre indivíduos juridicamente iguais e, portanto, submetidas aos códigos de direito privado, a crescente intensidade e magnitude dos conflitos gerados pela forma industrial de produção e acumulação de bens termina por provocar a ingerência do Estado no âmbito das relações de trabalho, em primeiro lugar, evoluindo, posteriormente, para o que, por costume, se denomina legislação previdenciária".
\end{abstract}

Assim

\begin{abstract}
“(...) a sequiência seguida pela legislação brasileira estaria conforme à tendência macro tendo-se iniciado com a proteção a acidentes do trabalho (1919), seguida por legislação simultânea sobre velhice, invalidez e morte (dependentes) e doença e auxílio-maternidade (1923), seguida por regulamento sobre abonos familiares (1941), e finalmente, uma espécie de auxílio-desemprego (1965)”.
\end{abstract}

Os montepios são as manifestações mais antigas de Previdência Social. Foram instituições que, pelo pagamento de cotas, cada membro adquiria o direito de, por morte, deixar pensão. O primeiro montepio surgiu em 1835 - o Montepio Geral dos Servidores do Estado (Mongeral). Em 1888, houve a criação de uma "Caixa de Socorro" para os trabalhadores de cada uma das estradas de ferro estatais. No final do século XIX, parcela dos trabalhadores urbanos foram incluídos em alguns benefícios muito restritos, como o direito à pensão de velhice. Eram os oficiais e algumas categorias de operários da casa da Moeda, dos telégrafos e da imprensa nacional. Para Faleiros (2000), o benefício era discriminatório entre 
os trabalhadores, o que mostra sua outorga em busca de uma lealdade seletiva por parte do governo, e não em razão de uma pressão exercida por esses grupos específicos.

Um decreto-lei de 1919 tornou compulsório o seguro contra o risco profissional (conhecido por lei dos acidentes de trabalho) e tinha um caráter indenizatório e privado, dependendo de um processo policial para definir a procedência da demanda (Araújo, 2004).

Faleiros (2000) argumenta que a lei sobre os acidentes de trabalho pode ser o resultado de uma pressão da classe operária, mesmo espontânea e anarquista. O núcleo principal do movimento operário, nessa época, fundamentava-se no anarquismo, com as uniões de resistência dirigidas pelos imigrantes europeus.

A rigor, no primeiro terço do Século $X X$, não se pode falar de legislação social sistemática no Brasil. O país se caracterizava por ser agrícola e exportador, apoiado na produção de café. O poder era controlado pela oligarquia rural e a ideologia dominante era o liberalismo, isto é, o contrato de trabalho sem intervenção do Estado.

O quadro que se seguiu à Primeira Guerra Mundial era mais favorável à intervenção estatal que o período histórico anterior, quando predominava o ideário liberal. O Tratado de Versalles e a criação da Organização Internacional do Trabalho (OIT) influenciaram no encaminhamento de ações voltadas para a proteção social no Brasil.

O marco legislativo e institucional da Previdência Social brasileira é a Lei Eloy Chaves (na verdade um Decreto Legislativo ${ }^{\circ} 4.682$ de 24 de janeiro de 1923), que criou as Caixas de Aposentadorias e Pensões (as CAPs), para as empresas de estradas de ferro, com abrangência a todos os seus empregados. Os benefícios da caixa dos ferroviários foram estendidos, depois, aos marítimos, em 1926. As CAPs foram as primeiras instituições previdenciárias do país.

A partir da Lei Eloy Chaves surgiram várias outras caixas de aposentadorias e pensões, sempre por empresas: portuárias, de serviços telegráficos, de água, energia, transporte ferroviário, gás, mineração, entre outras, chegando a atingir o total de cento e oitenta e três CAPs. 
A partir dessa Lei, a proteção social no Brasil passou a contar com uma instituição que oferecia pensão, aposentadoria, assistência médica e auxílio farmacêutico. Ainda hoje, a pensão e a aposentadoria são benefícios indispensáveis para que se caracterize uma instituição previdenciária. Até o ano de 1923, as instituições concediam apenas um ou outro benefício (MPS, 2004).

A partir de 1930, com o Governo de Getúlio Vargas, houve uma conjuntura de convergência de forças de oposição ao regime oligárquico. Essas forças se concentravam nas cidades e compreendiam uma camada importante de profissionais de nível superior e de técnicos. Nessa época transformou-se a dinâmica da implantação de medidas sociais. O país se industrializava e crescia o mercado interno.

Segundo Faleiros (2000), Getúlio realizou uma política pragmática, de busca de alianças para manter o pacto de dominação, combinando a distribuição de favores, a concessão de direitos, com a repressão e a integração dos trabalhadores. A política de seguros era fragmentária, reproduzindo as desigualdades entre os próprios trabalhadores, concedendo mais benefícios para os melhor situados.

Posteriormente, a Constituição de 1934 representou um grande avanço, ao incluir dispositivos de natureza social, previdenciária e um conjunto de preceitos a serem observados pela legislação do trabalho. Esse progresso foi, em parte, resultado da mobilização dos trabalhadores através de greves e reivindicações de direitos, do avanço da legislação trabalhista no mundo capitalista, mas foi também reflexo da Revolução de 1917 e dos efeitos da grande depressão de 1929, acontecimentos externos que estavam ainda muito recentes (Araújo, 2004).

A Constituição de 1934 teve o mérito de promover a transição da clássica declaração de direitos individuais de cunho liberal das constituições anteriores para uma proposta social de cunho intervencionista. Ela estabeleceu uma correlação entre os aspectos trabalhista, assistencial e previdenciário. Instituiu a previdência, a ser implementada com contribuição tripartida da União, do empregador e do empregado, em partes iguais, para atender a velhice, a invalidez, a maternidade e os acidentes do trabalho ou de morte. 
É importante observar que a contribuição tripartite como forma de custeio da Previdência Social foi omitida na Constituição de 1937, outorgada sob o regime ditatorial do Estado Novo e, restabelecida depois, pela Constituição de 1946.

Durante a década de 1930 foram surgindo, paralelamente às caixas, os Institutos de Aposentadoria e Pensões (IAPs), seguindo os setores da atividade econômica e não mais por fábrica. Os riscos cobertos por esses institutos eram os de doença, de invalidez, de velhice e de morte e funcionavam em regime de repartição simples7.

A legislação social foi introduzida por categoria profissional, isto é, não atingia a classe operária em seu conjunto e num único movimento. Para alguns intérpretes desse período, entretanto, os institutos de aposentadoria e pensões eram mais fortalecedores da classe operária que as caixas (Gentil, 2006). Embora tenham fragmentado os trabalhadores por categorias e tenham servido como instrumento do jogo político de Vargas, os institutos nacionalizaram as demandas - o que não ocorria com o sistema de caixas - e exerceram uma expressiva pressão política. Para outros, a transformação das caixas em institutos correspondeu a uma estratégia de centralização do poder federal, ao controle dos Estados por uma burocracia cada dia mais técnica e mais numerosa e a uma cooptação da classe operária. Segundo Araújo (2004), a Previdência Social nesse período era um valioso instrumento de contato com as massas, possibilitando uma doutrinação política sistemática, através da máquina publicitária oficial. A criação dos institutos teria também permitido aos patrões diminuir suas despesas e socializar os custos das caixas, com a contribuição dos trabalhadores de todo o país.

Em 1960, foi promulgada a Lei $\mathrm{n}^{\circ}$ 3.807, conhecida como Lei Orgânica da Previdência Social (LOPS), que, segundo Araújo (2004, p. 131),

(...) é considerada um marco na uniformização da legislação previdenciária, seja em termos de benefícios concedidos e de plano de custeio, seja pelo restabelecimento da participação dos segurados nos conselhos de administração fiscalização, orientação

\footnotetext{
${ }^{7}$ O modelo de repartição simples é o sistema de Previdência Social de solidariedade intergeracional e de ativos/inativos, segundo o qual o pagamento dos benefícios aos aposentados é feito com o montante arrecadado dos contribuintes, sem que haja necessariamente uma reserva. Já no modelo de capitalização, o sistema de pagamento de aposentadoria se faz através de um fundo individual aplicado, principalmente, em instituições financeiras. Elas retribuem as contribuições de acordo com o rendimento das aplicações após um período determinado de anos combinado com a idade. Há um adicional para a administração do fundo (FALEIROS, 2000, p.212).
} 
e controle da Previdência Social. Esses conselhos eram constituídos por representantes do governo, dos empregados e dos empregadores, retomando o modelo de gestão colegiada existente nas antigas Caixas, suprimido pelo governo autoritário de 1937. O Decreto $\mathrm{n}^{\circ}$ 48.959-A, de 10 de setembro de 1960, aprovou o Regulamento Geral da Previdência Social (RGPS), considerado um importante avanço legislativo rumo ao princípio da equidade (2004, p. 131).

Foi também a partir da LOPS, em 1960, que a forma de custeio tripartido da previdência foi modificada. A contribuição da União deixou de ser igual à dos segurados. Não participava mais do custeio da proteção social, mas, tornou-se responsável pelas despesas de administração geral, inclusive pessoal, e pela cobertura das insuficiências financeiras.

Em 1966, durante a ditadura militar, o Decreto $n^{\circ} 72$ unificou os IAP's, com exceção do Instituto de Previdência e Assistência dos Servidores do Estado (IPASE). A unificação da legislação, no que diz respeito ao custeio e aos benefícios previdenciários, já havia sido feita em 1960. O que se fez, seis anos depois, foi uma reforma essencialmente política e administrativa, com a fusão das instituições previdenciárias no Instituto Nacional de Previdência Social (INPS), vinculado ao Ministério do Trabalho, responsável, a partir daí, pelos benefícios previdenciários dos trabalhadores urbanos. Essa reforma, entretanto, não superou a concepção fragmentária e excludente que até então prevalecia. Com a uniformização de planos e benefícios, pôs fim a certa discriminação que existia entre os serviços prestados aos empregados e operários, mas mantinha intacta a estrutura fragmentária e excludente do sistema porque não mudava a estrutura real dos institutos. Era uma racionalização burocrática que visava reduzir os custos, as diferenças, mas ofereceu uma resposta mais simbólica que real aos problemas dos trabalhadores (FALEIROS, 2000).

Para Teixeira (2004, p. 23 apud Gentil, 2006, p. 105), a gestão previdenciária no período autoritário pode ser resumida em poucas palavras:

\footnotetext{
Um dos instrumentos sempre apontados para a cooptação da liderança sindical era o dos institutos previdenciários. Sob o regime militar, o sistema previdenciário continuou a desempenhar importante papel no jogo político, mas sob um novo formato. O clientelismo transfigurou-se, deixando de se exercer sobre uma base sindical e por categoria profissional para adquirir uma base regional; abandonou o sindicato e introjetou-se definitivamente no sistema político-eleitoral. O processo decisório, por sua vez, no âmbito do Instituto Nacional de Previdência Social INPS, tornou-se inteiramente impermeável à influência direta tanto das empresas quanto dos trabalhadores (que foram excluídos de sua direção). Com isso, pode-se ter uma visão mais clara da ambigüidade do processo de modernização vivido pela Previdência nesses anos, em que a ampliação da cobertura que o acompanha surge como uma espécie de contrapartida à repressão das demandas sociais, praticada pelo regime autoritário.
} 
Após o golpe de 1964, afirma Faleiros (2000) que as mudanças introduzidas na Previdência Social foram feitas como forma de legitimação, já que os direitos sociais dos segurados não modificavam os deveres de submissão dos cidadãos. A Previdência Social é um instrumento político não só em épocas de mobilização e democracia, mas também de autoritarismo e controle.

Avanços na legislação foram ocorrendo logo depois. São de grande importância: 1) a criação do Programa de Integração Social (PIS), em 1970; 2) a instituição do Programa de Assistência ao Trabalhador Rural (PRORURAL), em 1971, com execução a cargo do Fundo de Assistência ao Trabalhador Rural (FUNRURAL), incluindo os trabalhadores rurais na previdência - com um plano de benefícios muito inferior, pois a aposentadoria correspondia, então, a 50\% do salário mínimo - e estabelecendo uma solidariedade formal entre a área urbana e rural através do custeio dos benefícios - uma vez que não havia contribuição direta; 3) a inclusão dos empregados domésticos, com a Lei $n^{\circ} 5.859$, de 1972; e, 4) a inclusão dos trabalhadores autônomos, com a Lei nº 5.890, de 1973.

Em 1974 ocorre a criação do Ministério da Previdência e Assistência Social (MPSA). O sistema foi unificado em 1977, com a Lei $\mathrm{n}^{\circ}$ 6.439, que criou o Sistema Nacional de Previdência e Assistência Social (SINPAS), objetivando integrar as funções de concessão e manutenção de benefícios, prestação de serviços, custeio de atividades e programas e gestão administrativa, financeira e patrimonial da previdência e assistência social. Para o cumprimento dessa missão, foram criados o Instituto Nacional de Assistência Médica da Previdência Social (INAMPS), o Instituto Nacional de Previdência Social (INPS), o Instituto Nacional de Administração da Previdência Social (IAPAS), a Central de Medicamentos (CEME), a Empresa de Processamento de Dados da Previdência Social (DATAPREV), Fundação Nacional de Bem-Estar do Menor (FUNABEM) e a Legião Brasileira de Assistência (LBA). Também foi extinto o FUNRURAL e o IPASE, transferindo-se para o INPS a responsabilidade de conceder e manter os benefícios dos trabalhadores rurais e dos servidores públicos.

Para Gentil (2006), o movimento de criação do SINPAS não mudou as bases anteriores de sustentação e nem se articulou como um projeto de cidadania universal. Na verdade, estava longe de ser um movimento de cidadania. Era a continuidade de um modelo 
fragmentado e desigual de incorporação social em estratos de acesso. Prosseguiu funcionando o regime de repartição simples.

As décadas de 1970 e 1980 são consideradas importantes por terem gerado grandes avanços no sistema previdenciário brasileiro. Muitos benefícios foram criados nesse período como o salário-maternidade, renda mensal vitalícia para idosos e inválidos, aposentadorias e pensões para a força de trabalho rural, inclusão dos empregados domésticos, extensão dos benefícios de acidentes do trabalho aos trabalhadores rurais e outros.

Em 1988, a Constituição Federal, alcunhada de "Cidadã", implantou um novo conceito no Brasil: o de Seguridade Social, o que será objeto de análise nos próximos capítulos. 


\section{CAPÍtUlo II}

\section{TIPOLOGIAS DO ESTADO DE BEM-ESTAR E A TRAJETÓRIA DA PROTEÇÃO SOCIAL NO BRASIL}

Como visto no capítulo anterior, o século $\mathrm{XX}$ foi marcado pelo processo de crescente intervenção do Estado no campo social, dando origem ao que é conhecido hoje como Estado de Bem-Estar Social, Estado Providência, Welfare State ou, simplesmente, Estado Social ${ }^{8}$, que numa definição ampla é entendido como a mobilização em larga escala do aparelho de Estado em uma sociedade capitalista a fim de executar medidas orientadas diretamente ao bem-estar de sua população.

O reconhecimento progressivo de direitos nesse campo marcou a cena política e social de um grande número de países, visando, primeiramente, proteger os trabalhadores assalariados em situações de perda da capacidade de trabalho decorrentes de doença, velhice ou invalidez, assim como em situações de desemprego involuntário. Num segundo momento, ampliaram-se as garantias de proteção para inúmeras outras situações, com a organização de complexos sistemas que envolvem não apenas a oferta pública de benefícios monetários e de serviços nos campos da Previdência Social, assistência, educação, saúde, habitação, trabalho, família e pobreza, como também a participação de organizações privadas e públicas não estatais.

O desenvolvimento dos sistemas de proteção social regulados e garantidos pelo Estado, a partir de distintos padrões de intervenção, garantias e proteções, permitiu à pesquisa comparada ganhar progressiva relevância. Inicialmente influenciada por uma geração de estudos baseados na comparação entre os níveis e as modalidades de gasto, ela foi renovada após os anos de 1980, quando os estudos seguiram uma nova trajetória. Passaram, então, a buscar a identificação dos distintos regimes de proteção social, favorecendo a compreensão sobre as diferenças quantitativas (gasto e cobertura) e qualitativas (públicos-alvo, modalidades e forma de proteção, assim como sua integração com as iniciativas privadas,

\footnotetext{
${ }^{8}$ Neste estudo a expressão "Welfare State" equivale a Estado de Bem-Estar Social.
} 
sejam elas oriundas do mercado, da família ou do setor não lucrativo) que caracterizam as experiências internacionais.

Com o desenvolvimento das tipologias dos sistemas de proteção social e das pesquisas que lhe dão base, vem avançando o conhecimento sobre os modos de organização da intervenção pública no social. Tomando como referência as bases sobre as quais se organizam os sistemas instituídos nos diversos países, diferenças vêm sendo destacadas.

Desta sorte, este capítulo tem por primeiro objetivo apresentar um quadro geral dos principais modelos de Seguridade Social que se desenvolveram de forma não homogênea nos diferentes países, para em seguida apresentar as características da proteção social no Brasil.

\section{Tipologias do Estado de Bem-Estar Social}

\subsection{Os modelos bismarckiano e beveridgeano de Bem-Estar Social}

Mesmo antes de vir à tona as teorias mais sofisticadas dos regimes de política social, já eram referenciais teóricos dos modelos de Seguridade Social adotados pelos diversos países os sistemas idealizados por Otto Von Bismarck e William Beveridge.

As primeiras iniciativas de benefícios previdenciários, que são de modo geral reconhecidas como as precursoras do Estado de Bem-Estar Social contemporâneo, nasceram na Alemanha imperial, no final do século XIX, principalmente durante a década de 1880 , mais, precisamente, em 1883, durante o Governo do Chanceler Otto Von Bismarck, em resposta às greves e pressões dos trabalhadores.

Quando se analisam as políticas sociais bismarckianas, duas de suas características costumam ser destacadas: (a) seu caráter seletivo ou corporativo na medida em que, no princípio, seus únicos beneficiários era os operários industriais, considerados como uma categoria social que compartilhava os mesmos interesses; (b) e seu propósito explícito de pacificar os operários industriais, minar a organização trabalhista e promover a paz social. 
Neste particular, segundo Faria (2007, p. 55), “a Alemanha bismarckiana tornar-se-ia um paradigma para a análise do Welfare State como uma forma de manipulação bonapartista, isto é, como intervenção preventiva de elites precavidas contra o crescente poder do operariado”.

No entanto, o mesmo autor pondera (ibid, p. 55)

\begin{abstract}
“(...) que as políticas sociais de Bismarck cumpriram um papel essencial no processo de construção nacional durante o segundo Reich. Tendo como uma de suas principais metas consolidar a integração de Estados anteriormente independentes, a administração centralizada da Seguridade Social nacional foi estratégica para o Segundo Reich, que também precisava reafirmar no plano internacional seu poderio militar e industrial.
\end{abstract}

O chamado modelo bismarckiano é considerado como um sistema de seguros sociais, porque suas características assemelham-se às de seguros privados: no que se refere aos direitos, os benefícios cobrem principalmente (e às vezes exclusivamente) os trabalhadores, o acesso é condicionado a uma contribuição direta anterior e o montante das prestações é proporcional à contribuição efetuada; quanto ao financiamento, os recursos são provenientes, fundamentalmente, da contribuição direta de empregados e empregadores, baseada na folha de salários; em relação à gestão, teoricamente (e originalmente), cada benefício é organizado em Caixas, que são geridas pelo Estado, com participação dos contribuintes, ou seja, empregadores e empregados. Esse modelo orientou e ainda influencia muitos benefícios da Seguridade Social, sobretudo, os benefícios previdenciários.

Característica inovadora do modelo bismarckiano corresponde ao fato do acesso aos benefícios oferecidos pelos seus programas constituir direito do trabalhador em contraprestação às contribuições vertidas, rompendo com a tradição das leis de assistência pública que exigiam a comprovação da necessidade ou da carência do cidadão para acesso aos serviços e prestações disponíveis.

Em outro contexto econômico e político, durante a Segunda Guerra Mundial, mais precisamente em 1942, é formulado na Inglaterra o Plano Beveridge, que apresenta críticas ao modelo bismarckiano vigente até então, e propõe a instituição do Welfare State. No sistema beveridgiano, os direitos têm caráter universal, destinados a todos os cidadãos incondicionalmente ou submetidos a condições de recursos, mas garantindo mínimos sociais a todos em condições de necessidade. O sistema seria financiado pelas contribuições de seus 
membros e de seus respectivos empregadores, mas o Estado, a partir da renda proveniente dos tributos em geral, deveria cobrir um sexto da maioria dos benefícios de seguridade, a totalidade dos abonos de família e a maior parte dos custos do Serviço Nacional de Saúde. Os princípios fundamentais são a unificação institucional e uniformização dos benefícios.

Nesse sentido, a concepção de proteção social como seguro avançava em direção à idéia de Seguridade Social, segundo a qual o Estado responsabiliza-se, em nome da sociedade, por proteger o cidadão que se encontre, eventualmente, em dificuldades colocadas para sobreviver em uma economia de mercado - especialmente aquelas que o impedem de prover o próprio sustento: doença, invalidez, velhice, entre outras (Vianna, 1998).

As diferenças entre os modelos bismarckiano e beveridgeano provocaram o surgimento e instituição de diferentes modelos de Seguridade Social nos países capitalistas, com variações determinadas pelas diferentes relações estabelecidas entre o Estado e as classes sociais em cada país. Hoje, é difícil encontrar um modelo puro. As políticas existentes e que constituem os sistemas de Seguridade Social em diversos países apresentam as características dos dois modelos, com maior ou menor intensidade. No Brasil, por exemplo, veremos que os princípios do modelo bismarckiano predominam na Previdência Social, e os do modelo beveridgiano orientam o atual sistema público de saúde e de assistência social, o que faz com que a Seguridade Social brasileira se situe entre o seguro e a assistência social.

\subsection{A precursora tipologia tricotômica de Richard Titmuss e os três mundos do bem-estar capitalista de Esping-Andersen}

Richard Titmuss (1958) sugeriu a existência de três funções ou modelos contrastantes de política social. Para Faria (2007), sua tipologia precursora ressalta a lógica da intervenção do estado, com apelo para que não se tomem parâmetros econômicos com as únicas medidas da provisão de bem-estar e das condições de vida.

Os modelos ou tipos-ideais de política social de Titmuss são: o Modelo Residual de Bem-Estar, o Modelo de Produtividade e Desempenho Industrial e o Modelo Redistributivo Institucional. 
No modelo Residual, a provisão pública de bem-estar intervém de forma mínima e temporária apenas quando os mecanismos habituais - mercado e a família - não são suficientes para a satisfação de necessidades básicas do indivíduo, de forma a atender pequena parcela da população, os muito pobres. O Estado encenaria, assim, papel marginal, do ponto de vista da oferta de benefícios e serviços sociais, enquanto a família e as instituições privadas do mercado desempenhariam papel preponderante. Titmuss afirmava como máxima deste modelo que "o verdadeiro objetivo do Estado de Bem-Estar Social é ensinar as pessoas a viverem sem ele" (apud FARIA, 2007, p. 62), podendo ser tomada como uma das mais remotas origens da conhecida expressão popular "ao invés de dar o peixe, ensina-lhe a pescar".

No tipo-ideal de Produtividade e Desempenho Industrial, explica Faria (ob. cit., p. 62/63):

\begin{abstract}
Embora esse modelo atribua um papel predominante às instituições privadas de mercado, os mecanismos estatais de proteção social cumprem um papel significativo, na medida em que são considerados complementares à economia. As necessidades individuais devem ser supridas de acordo com o mérito, a produtividade e o desempenho no trabalho. A definição dos beneficiários e o cálculo do impacto esperado das políticas sociais são pautados pela idéia de concessão de incentivos e de recompensas, levando em consideração o empenho individual. No "mundo real", essa concepção teria dado origem à vinculação do valor dos benefícios ao nível de renda do beneficiário.
\end{abstract}

Já em relação ao terceiro e último modelo idealizado por Titmuss, o Redistributivo Institucional, esclarece o mesmo autor que (ob. cit., p. 63)

\begin{abstract}
As instituições públicas de bem-estar social assumem um papel essencial nesse modelo. Os serviços e benefícios são proporcionados de forma universalista, independentemente do mercado e tomando por base o princípio da necessidade. $\mathrm{O}$ bem-estar individual é visto como responsabilidade da coletividade e a meta é alcançar uma maior igualdade entre os cidadãos. Segundo Titmuss, trata-se "basicamente de um modelo que comporta sistemas de redistribuição com command-over-resources-through-time". Existe uma noção de mínimo social, no sentido de que todas as pessoas têm direito à cidadania plena e, portanto, a usufruir de um padrão de vida digno.

(...) se é possível interpretar a teoria de Marshall acerca do progresso dos direitos de cidadania como uma espécie de desdobramento teórico das propostas de Beveridge para a Inglaterra, os modelos de política social de Titmuss podem ser vistos como derivados de experiências históricas distintas. Em outras palavras, as fontes históricas dos três modelos apresentados como tipos-ideais são, respectivamente, a experiência norte-americana (modelo Residual), as políticas bismarckianas (modelo de Produtividade e Desempenho industrial) e o legado de Beveridge (modelo Redistributivo Institucional).
\end{abstract}


Depois de um longo período sem surgir novas tricotomias, interstício em que prevaleceram os modelos polares, isto é, da dicotomia Residual/Institucional, em 1990, Esping-Andersen publicado o trabalho intitulado The Three Words of Welfare Capitalism ${ }^{9}$, que se tornaria referencial sobre o Welfare State durante o último décimo do Século XX.

Explica Faria (2005, p. 66) que

A razão de este trabalho ter se tornado referencial é que ele, baseando-se na comparação de uma ampla gama de informações e dados referentes a vários países industrializados, propôs uma revisão conceitual e teórica de Welfare State, distinguindo três diferentes "regimes do Estado de Bem-Estar Social" (Welfare State regimes), os quais, em essência, correspondem à pioneira tipologia tricotômica das políticas sociais e dos sistemas de bem-estar de Titmuss.

A partir da obra de Esping-Andersen, tornou-se clássica uma nova identificação de três regimes de proteção social: o social-democrata, o conservador-corporativo e o liberal.

Batista et al (2008, p. 21 e 22) identificam as características específicas de cada um dos três grandes regimes, assim expondo sinteticamente:

\begin{abstract}
O regime social-democrata representado pelos países nórdicos, caracteriza-se pela manutenção de uma proteção social abrangente, em termos da população coberta e da oferta de serviços e benefícios. Seu escopo é universal e seu objetivo é a garantia de proteção e de atendimento das necessidades consideradas essenciais a todos os cidadãos. Os benefícios monetários são de montante elevado, integrando prestações contributivas e não contributivas. As pensões de caráter não contributivo têm valor uniforme e o acesso é garantido a toda a população em idade ou condição de requerê-las. Paralelamente, os países associados a esse regime desenvolvem ampla oferta de serviços públicos, em grande parte gratuitos e geridos diretamente pelo Estado. Seu objetivo é garantir a coesão e a homogeneidade social, privilegiando o princípio da igualdade.

Um segundo regime, identificado como conservador-corporativo e desenvolvido por países da Europa continental, como Alemanha, França e Áustria, mantém-se ancorado em um sistema de seguro social de natureza obrigatória voltado à proteção dos riscos sociais, cujo objetivo principal e garantir renda aos trabalhadores nas situações de impossibilidade de acesso ao mercado de trabalho. Ofertam-se benefícios financiados por contribuições de trabalhadores e empregadores, ao qual podem ser acrescidos recursos públicos. O montante dos benefícios tende a ser proporcional ao valor das contribuições, procurando-se construir uma correspondência, no período de inatividade, com o padrão de vida do trabalhador quando ativo. Nesse regime, a administração dos seguros sociais é organizada em múltiplas caixas profissionais, que mantêm certa autonomia com relação ao Estado. Cabe lembrar, entretanto, que os países representados por esse modelo tenderam, ao longo de sua trajetória, a implementar também benefícios monetários não
\end{abstract}

\footnotetext{
${ }^{9}$ Neste estudo, trabalhamos com a versão em língua portuguesa denominada As três economias políticas do Welfare State, Lua Nova, n. 24, set. 1991, p. 85-116.
} 
contributivos, de modo a atender situações específicas de demanda por proteção social. Nesse grupo, à exceção dos serviços de saúde, os demais serviços sociais se desenvolveram de forma menos expressiva.

O chamado regime liberal, por sua vez, garante uma proteção residual, com benefícios monetários contributivos e não contributivos de valores pouco elevados assentados no objetivo de combater a pobreza e garantir um mínimo social. Representado, entre outros, por países como Reino Unido, Irlanda, Canadá e Estados Unidos, nesse regime observa-se uma forte presença de benefícios dirigidos aos grupos mais pobres, acompanhados pela limitada oferta de serviços públicos, à exceção, em certos casos, dos serviços de saúde, de cobertura universal.

Batista et al (ibidem, p. 22) ainda faz referência ao surgimento de um quarto modelo de proteção social, verbis:

\begin{abstract}
A tipologia proposta por Esping-Andersen vem sendo complementada por outros autores, que sugerem o reconhecimento de um quarto regime de proteção social, que expressaria a experiência diferenciada dos países do sul da Europa, em especial, Espanha, Itália, Grécia e Portugal. Nesse grupo - chamado de regime mediterrâneo - é forte a presença dos seguros sociais, com benefícios contributivos proporcionais ao salário e em montantes generosos. Nesse sentido, esse regime se aproxima substancialmente do regime conservador-corporativo. Contudo, a proteção dada aos idosos face à limitada proteção a outros grupos sociais - como pode ser deduzido da quase ausência de prestações voltadas à família, da limitada oferta de serviços pessoais e de serviços às crianças, assim como da baixa intervenção pública no campo da habitação e da assistência social - marcariam as diferenças desses países com relação aos demais regimes identificados. A forte presença da família atuando em redes de solidariedade também caracterizaria esses países, onde a proteção pública aos setores assalariados da força de trabalho convive com relevante percentual de trabalhadores dedicados a atividades econômicas informais e não protegidos pelos regimes contributivos de Previdência Social. Por fim, chama a atenção o fato de esses países contarem como sistemas universais de serviços de saúde.
\end{abstract}

Como afirma Vianna (1998), a extensão territorial, a formação histórica, o tipo de economia seriam, dentre outras variáveis, fatores que determinariam em diversos países a organização das políticas públicas na érea social. Em alguns, a estrutura organizacional evoluiu da pequena comunidade para o Estado nacional. Em outros, observa-se que o governo central nasceu primeiro e se expandiu mediante ordenamento de funções e delegação de poderes. Por condicionamentos tão diversos, pode-se dizer que não há, entre as nações, estrutura político-administrativa concebida por uma óptica semelhante.

Em geral, as variáveis desenvolvimento sócio-econômico (industrialização e urbanização no contexto da organização capitalista da produção) e mobilização da classe operária (pressão versus ações defensivas do sistema político através das instituições do Welfare) e, mais proximamente, o desenvolvimento institucional (extensão do sufrágio, 
características do regime político), produzem efeitos convergentes que explicam a emergência dos Welfare, assim como as características que os diferenciarão entre si (VIANNA, 1998).

Vianna (ob. cit., p. 26) critica a capacidade das políticas sociais de interferir no processo de distribuição da renda/riqueza socialmente produzida. Para esta autora

\begin{abstract}
(...) o Welfare State não é uma tentativa de intervir sobre a distribuição de renda no mercado; é após a distribuição de renda efetuada no mercado que esforços são feitos para reduzir a desigualdade entre aqueles que estão no mercado de trabalho e aqueles que estão fora e, em menor extensão, entre os empregados de modo geral. Ou seja, quanto menos o mercado "distribui", maiores esforços serão necessários depois, o que, no limite, significa que baldados serão os esforços redistributivos pósmercado quando este se encarrega de sulcar desigualdades profundas no tecido social.
\end{abstract}

A discussão da implementação de uma política de mínimos sociais, tanto no Brasil como no mundo, tenta avançar na idéia do direito a uma renda independentemente da "capacidade de contribuição" na produção social da riqueza. Essa concepção tenderia a estar mais próxima de um modelo "tipo-ideal" de Welfare, o Institucional-Redistributivo, pois o processo de democratização social do capitalismo deveria avançar para além da construção de um modelo de Welfare State, deveria aprofundar o processo de democratização do modo capitalista de produção, uma efetiva "democratização social do mercado":

(...) a democratização social do capitalismo implica preencher uma agenda de quatro pontos: desmercadorização do status da força de trabalho (alcançável na medida em que se institui o "salário social" e os direitos de cidadania suplantam os mecanismos de distribuição do mercado); reforço da solidariedade, ou seja, substituição dos esquemas de proteção social competitivos, seletivos ou corporativos pelo princípio do universalismo (segundo o qual todos os cidadãos compartilham a noção de "estar no mesmo barco"); redistribuição efetiva, via tributação progressiva e transferências sociais; e pleno emprego, como meta e como base financeira para a consecução dos demais objetivos (VIANNA, 1998, p.26).

\title{
2. Estado de Bem-Estar Social no Brasil
}

\subsection{Antecedentes da Constituição Federal de 1988}

Antes da década de 1930, o Brasil não tinha articulado um sistema de proteção social, a confirmar o silêncio sobre a questão nas primeiras Cartas de 1824 e 1891. A este respeito, escreve Santos (1987, p. 15-16) 
A primeira Constituição brasileira, de 1824, não apresenta nenhuma originalidade em relação às demais constituições da época, no que diz respeito à problemática social. Muitas décadas ainda transcorreriam, no mundo e no Brasil, até que as elites dominantes, sob pressão de contra-elites, ou mesmo das massas, como sugerem alguns investigadores (Pryor), ou em movimento antecipatório visando apaziguar os conflitos que seriam certamente gerados pelos processos de acumulação, segundo outros (Malloy), se dispusessem a considerar a existência de um problema social que incumbia ao poder político, simbolizado pelo Estado, administrar. Embora os efeitos perversos da acumulação econômica por via do crescimento da produção industrial fossem já visíveis na Inglaterra, na França e nos Estados Unidos, principalmente, a inexistência de movimentos reivindicatórios organizados facilitava a hegemonia indisputada da crença em que o 'mercado', onde se encontravam indivíduos juridicamente iguais e autônomos, capazes de firmar acordos que a ninguém mais interessava, constituía o mecanismo mais eficiente, malgrado suas falhas setoriais e ocasionais, para combinar as mais elevadas taxas de acumulação de riquezas à mais justa distribuição possível de benefícios econômicos e, em decorrência, sociais.

(...) O Brasil de 1824, apoiado em uma organização escravista da produção, ao mesmo tempo em que iniciava a construção de um Estado nacional sob a inspiração de discípulos do liberalismo progressista da época, constituiria esdrúxulo exemplo de desvio ideológico e organizacional, caso estruturasse sua vida jurídica em descompasso com o que havia de mais 'avançado' à época. Em realidade, ao desconhecer a existência de um problema social, por um lado, e ao recusar-se a regular profissões, abolindo as remanescentes corporações coloniais de ofício, por outro, a Constituição de 1824 acertava seu passo com a modernidade de início do século XIX.

O princípio da não-regulamentação das profissões, capítulo importante do tratado laissez-fairiano da organização social, será reafirmado pela Constituição republicana de 1891, que consagrará seu parágrafo 24 , artigo 72 , mesmo após a revisão constitucional de 1926, ainda uma vez, à liberdade das profissões, arcaico eco, em pleno século XX, do ideário anticorporativo do século XVIII.

Ainda sobre a influência do pensamento liberal na evolução da questão social no Brasil, Santos (1987, p. 64) afirma que

A tentativa de organizar a vida econômica e social do país segundo princípios laissez-fairianos ortodoxos expande-se, teoricamente, da abolição do trabalho escravo, em 1888, até 1931, quando o então chefe do governo revolucionário, Getúlio Vargas, anuncia, repetidamente, a necessidade de significativa intervenção do Estado na vida econômica com o propósito de estimular a industrialização e a diferenciação econômica nacional.

Portanto, é a partir da década de 1930 que se assiste, no Brasil, à gênese de um sistema nacional de políticas sociais. Conforme Draibe, Castro e Azeredo (1991), ao menos três fatores permitem localizar nos anos 1930 este momento. Primeiro, a ampliação do escopo da atuação social do Estado, por meio da incorporação de modalidades adicionais de bens e serviços sociais - por exemplo, a diversificação dos benefícios previdenciários, assistenciais e trabalhistas; a organização da atenção à saúde no âmbito da assistência médica previdenciária; e a expansão dos ensinos fundamental e médio. Segundo, a esta maior amplitude na provisão 
de bens e serviços sociais correspondeu o surgimento de um conjunto de leis referentes à criação de órgãos gestores de políticas sociais e à garantia de direitos trabalhistas, que estabelecem um marco legal e institucional nacional, permitindo revelar complementaridades antes inexistentes. Por fim, é o Estado nacional que vai assumir o papel de regulador e articulador,

Assim, o Estado desenvolveria naquele momento ações voltadas para a promoção da eqüidade, consistentes e complementares à sua política de acumulação. Nos primeiros anos, o sistema permaneceu, como aponta Draibe, Castro e Azeredo (1991), seletivo, heterogêneo e fragmentado. A seletividade destacada pelos autores diz respeito ao reduzido número de beneficiários atendido pelo sistema. Embora a maioria das categorias profissionais urbanas tenha sido gradativamente incorporada ao sistema, um amplo contingente permaneceu excluído, como os trabalhadores autônomos, domésticos e rurais. A heterogeneidade refere-se ao plano de benefícios. Algumas categorias profissionais possuíam uma gama maior de benefícios em relação a outras. A fragmentação, por sua vez diz respeito à multiplicidade de instituições, com situações financeiras e bases de arrecadação diferenciadas, que respondiam pela cobertura previdenciária da população incluída.

As drásticas transformações ocorridas na economia e no Estado brasileiro, a partir da instauração do regime militar acarretaram mudanças sensíveis no sistema de proteção social brasileiro, durante as décadas de 1960 e 1970. Estas mudanças foram operadas no sentido da expansão do sistema, em busca de uma abrangência nacional, por meio de um aparelho estatal centralizado. Amplia-se o grau de racionalidade do sistema previdenciário, buscando-se novas fontes de financiamento e redefinindo-se seus princípios e mecanismos operacionais.

No entanto, esse movimento não significou uma ruptura drástica com o padrão excludente anterior. Alguns dos componentes de iniqüidade do sistema são acentuados, a despeito da progressiva incorporação de novos grupos sociais. A proteção social continuava fortemente baseada na capacidade contributiva dos trabalhadores, reproduzindo as injustiças e as desigualdades predominantes na sociedade. Os mecanismos com potencial de combater as desigualdades e a pobreza, por meio de políticas assistenciais e não contributivas, eram muito frágeis, na medida em que não constava das responsabilidades do Estado a garantia de direitos sociais básicos a todos os cidadãos, indiferentemente de sua participação ou não no processo 
de produção. Destaque-se também a exclusão da representação social - especialmente de trabalhadores - nas instâncias gestoras do sistema.

Observa Medeiros (2001, p. 10) que

\begin{abstract}
As circunstâncias do surgimento e do desenvolvimento do Welfare State no Brasil são diferentes das observadas nos países aos quais as teorias mencionadas se referem. Além de ocorrer sob uma posição diferente na economia mundial, o processo de modernização brasileiro é marcadamente segmentado, com setores industriais modernos convivendo com setores tradicionais e com a economia agrárioexportadora.

O controle do mercado para produtos industriais por meio de políticas de massificação do consumo foi um aspecto secundário para um Estado preocupado com estratégias protecionistas, disponibilidade de insumos e investimentos em bens de capital e infra-estrutura. No período de industrialização do Brasil, a possibilidade de se utilizar o Welfare State como instrumento de controle da demanda agregada era reduzida. Problemas de superprodução estavam muito mais relacionados ao comportamento do setor externo do que a flutuações nos níveis nacionais da demanda e o número restrito de trabalhadores beneficiados limitava a efetividade das políticas como mecanismo de expansão do consumo. No Brasil, o Welfare State surge a partir de decisões autárquicas e com caráter predominantemente político: regular aspectos relativos à organização dos trabalhadores assalariados dos setores modernos da economia e da burocracia.
\end{abstract}

Destaca-se, neste ponto, a centralidade do Estado na regulação do mercado nacional de trabalho e na conformação de certo padrão de proteção social a ele diretamente vinculado, por uns chamado de "modelo meritocrático-contributivo" (nesse sentido Draibe e Aureliano, 1989), por outros de "cidadania regulada", esta última expressão cunha por Santos (1987, p. $68)$.

Sugiro que o conceito-chave que permite entender a política econômico-social pós(19)30, assim como fazer a passagem da esfera da acumulação para esfera da eqüidade, é o conceito de cidadania, implícito na prática política do governo revolucionário, e que tal conceito poderia ser descrito como o de cidadania regulada. Por cidadania regulada entendo o conceito de cidadania cujas raízes encontram-se, não em um código de valores políticos, mas em um sistema de estratificação ocupacional, e que, ademais, tal sistema de estratificação ocupacional é definido por norma legal. (...) A cidadania está embutida na profissão e os direitos do cidadão restringem-se aos direitos do lugar que ocupa no processo produtivo, tal como reconhecido por lei.

No entanto, o capitalismo aqui instalado e a atuação regulatória do Estado no campo trabalhista, não lograram universalizar o fenômeno do assalariamento formal do trabalho, tornando incompleto o "processo civilizatório" de um capitalismo minimamente organizado, tal qual levado a cabo na experiência norte-americana e de alguns países europeus ocidentais. 
Nesse toar, mesmo enquadrado no tipo meritocrático, os efeitos e o alcance do sistema de proteção social brasileiro até a Constituição de 1988 eram bastante distintos dos verificados nos países europeus de modelo semelhante, devido às características conservadoras do rápido processo de crescimento econômico do país, no período. Enquanto nos países centrais este processo ocorreu em meio ao pleno emprego e ao aumento de salários, resultando em elevação dos níveis de vida de sua população, no Brasil, as condições do mercado de trabalho eram, para a maioria dos trabalhadores, marcadas pelo desemprego, pelos baixos salários e pela informalidade.

De acordo com Draibe, Castro e Azeredo (1991), estas condições trariam como consequiência alguns fatores limitantes do sucesso do sistema, quais sejam: a) uma estreita base contributiva, decorrente dos baixos níveis salariais; b) níveis de qualidade necessariamente insuficientes, dado o subfinanciamento; c) tendência à assistencialização das políticas sociais, que se tornaram mais focalizadas e seletivas; e d) sobrecarga de demanda, já que era preciso atender a cerca de um terço da população, não inserida formalmente no mercado de trabalho, além de parte considerável dos outros dois terços, os quais, mesmo quando empregados e assalariados, também necessitavam da assistência do Estado.

Diante de tais características, concluem Draibe, Castro e Azeredo (1991, p. 83), que

(...) parece ter sido reduzida no Brasil a capacidade das políticas sociais alterarem a estrutura de oportunidades, contribuindo assim para diminuir os graus de desigualdades nas condições básicas de vida e nas probabilidades com que os indivíduos e as famílias acessam e se beneficiam dos próprios programas sociais.

Acrescenta Medeiros (ob. cit., p. 22)

\begin{abstract}
O caráter redistributivo do Welfare State brasileiro foi comprometido: primeiro, pela elevada segmentação da sociedade resultante de um modelo de desenvolvimento concentrador; segundo, pela ausência de coalizões entre trabalhadores industriais e não industriais; e terceiro, por uma burocracia com baixos níveis de autonomia em relação ao governo. As políticas sociais são estruturadas com base em princípios de autofinanciamento; e distribuídas por critérios particularistas, o que não apenas limita o universo de beneficiários como também torna os gastos sociais extremamente regressivos.
\end{abstract}

Ressalta, contudo, IPEA (2009b) que, embora frágeis, as políticas assistenciais assumiram grande relevância no período, dada a baixa cobertura do sistema contributivo, assim como os baixos salários. Embora por princípio seu atendimento devesse ser residual, 
terminava por atender, na prática, a parcelas significativas da população, assalariada ou não, o que teve o efeito adicional de abrir espaço para ampla utilização clientelista das políticas sociais.

De fato, apesar de o sistema de proteção social brasileiro ter mantido suas características meritocráticas até a promulgação da Constituição de 1988, este incorporou um grande contingente de segurados, nas décadas de 1960 e 1970. Com o acelerado crescimento econômico do período do "milagre", a massa salarial aumentou e foi possível elevar o número de contribuintes e beneficiários do INPS. Isso foi essencial para a expansão e a consolidação da assistência médica previdenciária e, mais tarde, para a ampliação do acesso não contributivo ao sistema de saúde. O que foi feito por meio do Programa de Pronta Ação (PPA), no qual qualquer pessoa, contribuinte ou não da Previdência Social recebe atendimento médico de emergência por meio do INPS.

A reversão do crescimento do PIB, observada no fim dos anos 1970, colocou a gestão financeira da previdência e da assistência médica previdenciária em xeque, pois a crise reduziu o volume de emprego e a massa salarial, apesar de o número de benefícios continuarem se elevando. A configuração extremamente pró-cíclica da estrutura de financiamento das políticas sociais, que tinha se mostrado tão virtuosa no período de acelerado crescimento econômico, impõe um rápido estrangulamento ao sistema de políticas sociais então em vigor: justamente quando as carências sociais ampliavam-se, as fontes de financiamento das políticas sociais enfrentavam quedas drásticas. E tudo isto sob um contexto de abertura que, se era lenta, gradual e segura, conviveu com a reorganização da sociedade civil, que recuperava a capacidade de pressão dos movimentos sociais.

Dessa maneira, conclui IPEA (2009b, p. 26)

(...) o início dos anos 1980 trouxe, em seu contexto de redemocratização e forte crise econômica, um claro esgotamento do sistema nacional de políticas sociais em vigor até então. A constatação de que o elevado crescimento econômico das décadas anteriores não havia proporcionado os níveis de desenvolvimento social esperados e a frustração das expectativas quanto à possibilidade de o assalariamento formal tornar-se regra geral no mercado de trabalho revelou, de modo inequívoco, a insuficiência do modelo meritocrático para fazer frente às necessidades sociais dos brasileiros. 
Para arrematar, Santos (1987, p. 80) descreve o sistema de proteção social brasileiro pré-constituição de 1988, em termo de comparação internacional,

(...) como um sistema misto que segue o plano Beveridge, inglês, no que diz respeito à unificação e uniformização dos serviços médicos, absorve o sistema alemão no que diz respeito à diferenciação dos benefícios pagos em função da renda auferida na aposentadoria (ao contrário do pagamento de um '"lat benefit" do plano Beveridge), e assemelhasse ao programa americano pelo seu aspecto contratualista entre o segurado e o Estado, antes que como direito inerente à cidadania, como na fórmula inglesa".

\subsection{A Constituição Federal de 1988 e a Seguridade Social}

Como relembrado na seção anterior, a gênese, a expansão e a consolidação de um sistema de políticas sociais no Brasil, sob os princípios conservadores da vertente meritocrática, não elencavam entre seus objetivos principais a erradicação da pobreza e a diminuição forte e sustentada da desigualdade. Contudo, com o processo de organização da sociedade civil, na luta pela redemocratização, verificado a partir de meados dos anos 1970, as forças oposicionistas delinearam uma extensa agenda de mudanças políticas, econômicas e sociais, que compunha um amplo projeto de reforma de cunho nacional, democrático, desenvolvimentista e redistributivo. A construção de um efetivo Estado de Bem-Estar Social, universal e equânime, era um dos pilares deste projeto (Fagnani, 2005).

O conjunto de mudanças a serem buscadas incluía, para além da restauração do Estado democrático de direito, a reconfiguração do sistema nacional de políticas sociais, em direção a um modelo redistributivista de proteção social, semelhante ao dos estados de bem-estar social europeus, constituídos no pós-guerra.

Esta não seria, contudo, uma tarefa fácil, na medida em que o momento era duplamente problemático: primeiro, porque o país atravessava uma crise econômica que afetava negativamente o quadro de pobreza e desigualdades; em segundo lugar, porque tais propostas surgiam precisamente na contramão do pensamento que se tornava hegemônico no cenário internacional, o qual pregava justamente a desconstrução de políticas sociais abrangentes e universais. 
Com a vitória de Tancredo Neves no Colégio Eleitoral e a posterior posse de José Sarney na Presidência, inicia-se o governo da Nova República, no interior do qual tinham vez as primeiras tentativas de reestruturação nas políticas sociais brasileiras.

Contudo, o restabelecimento da democracia e do Estado de direito, bem como as soluções imaginadas para as crises econômica e social do país, seriam efetivamente buscadas na convocação de uma Assembléia Nacional Constituinte. Esta acabou por ser convocada pela EC nº. 26, de 1985, e instalada no dia 1o de fevereiro de 1987. Daí em diante, os esforços reformistas direcionam-se fundamentalmente à Constituinte.

Após meses de trabalho e diversos embates políticos, comentam Castro e Cardoso Jr. (2005, p. 182) que a nova Carta foi promulgada lançando as bases

\begin{abstract}
(...) para uma expressiva alteração da intervenção social do Estado, alargando o arco dos direitos sociais e o campo da proteção social sob responsabilidade estatal, com impactos relevantes no que diz respeito ao desenho das políticas, à definição dos beneficiários e dos benefícios. A ampliação das situações sociais reconhecidas como objeto de garantias legais de proteção e submetidas à regulamentação estatal implicaram significativa expansão da responsabilidade pública em face de vários problemas cujo enfrentamento se dava, parcial ou integralmente, no espaço privado. A intervenção estatal, regulamentada pelas leis complementares que normatizaram as determinações constitucionais, passou a referir-se a um terreno mais vasto da vida social, tanto com objetivos de equalizar o acesso a oportunidades, como de enfrentar condições de destituição de direitos, riscos sociais e pobreza.
\end{abstract}

Por intermédio da garantia dos direitos civis, sociais e políticos, a Constituição de 1988 buscaria construir uma sociedade livre, justa e solidária; erradicar a pobreza e a marginalização; reduzir as desigualdades sociais e regionais; e promover o bem de todos sem preconceitos ou quaisquer formas de discriminação. Para tanto, a nova Carta combinaria as garantias de direitos com a ampliação do acesso da população a bens e serviços públicos.

Entre os principais avanços proporcionados pela $\mathrm{CF} / 88$ vale destacar a introdução do conceito de Seguridade Social, para expressar um arranjo consistente com uma ampla rede de proteção aos riscos sociais inerentes ao ciclo de vida, à trajetória laboral e à insuficiência de renda, agravados por um modelo econômico excludente e pela perversa distribuição de renda do país. O art. 194 da nova Carta assim o define: “A Seguridade Social compreende um conjunto integrado de ações de iniciativa dos poderes públicos e da sociedade, destinadas a assegurar os direitos à saúde, à previdência e à assistência social". 
A importância dessa inovação pode ser avaliada quando se contemplam os princípios orientadores da Seguridade Social, elencados no citado art. 194 da CF: universalidade da cobertura e do atendimento; uniformidade e equivalência dos benefícios e dos serviços às populações urbanas e rurais; equidade e distributividade na prestação dos benefícios e dos serviços; irredutibilidade do valor dos benefícios; equidade na forma de participação no custeio; diversidade da base de financiamento; caráter democrático e descentralizado da gestão administrativa, com a participação da comunidade, em especial de trabalhadores, empresários e aposentados.

Para implementar o conceito de Seguridade Social, a Constituição previu a criação do orçamento da Seguridade Social e a unificação das áreas de saúde, previdência e assistência social, no Ministério da Seguridade Social, o que favoreceria a integração dos recursos e a sinergia das ações de todas estas pastas. Esperava-se ainda, com esta decisão, garantir a preservação dos recursos para estes setores, contra as pressões das demais áreas de política pública. Para tanto, este orçamento deveria dispor de fontes diversas e exclusivas de financiamento, oriundas de contribuições de toda a sociedade: trabalhadores e empresários; União, estados e municípios; além das receitas oriundas de loterias.

Além disso, alcançaram-se alguns progressos a respeito dos direitos trabalhistas e previdenciários: o salário mínimo, fixado em lei, nacionalmente unificado; e o estabelecimento do princípio da vinculação entre salário mínimo ao piso dos benefícios previdenciários e assistenciais permanentes. A equiparação dos direitos dos trabalhadores rurais aos urbanos, suprimindo as diferenças existentes nos planos de benefícios da previdência, certamente foi um dos pontos altos destas mudanças. O trabalhador rural passava ainda a ter direito a uma aposentadoria por idade aos 60 anos e, no caso das mulheres, aos 55 anos, portanto, cinco anos antes da idade mínima exigida, em regra, ao trabalhador urbano.

As principais mudanças no financiamento da política social estão no capítulo que trata da Seguridade. Lá está reunida a maior parte do conjunto das contribuições sociais, espécie de tributo, agora vinculada ao custeio das ações de saúde, previdência e assistência. A inclusão do faturamento e do lucro, além da folha de salários, com bases para a contribuição do empregador à seguridade representou a desejada diversificação das fontes de financiamento. 
Além disso, canalizaram-se à Seguridade outras fontes de recursos importantes que são o Fundo de Investimento Social (FINSOCIAL), o Programa de Integração Social (PIS) e o Programa de Formação do Patrimônio do Servidor Público (PASEP). O FINSOCIAL veio fortalecer o custeio da Seguridade Social, este que já era a terceira fonte de arrecadação tributária da União no fim dos anos 1980, ficando abaixo apenas do imposto de renda (IR) e do Imposto sobre Produtos Industrializados (IPI). Quanto ao PIS/PASEP, foi sua vinculação ao custeio do seguro-desemprego que permitiu a instituição para valer de um verdadeiro sistema público de emprego - que tinha sido criado em 1986, antes da Constituição, mas que só ganhou musculatura financeira à altura com a montagem do Fundo de Amparo ao Trabalhador (FAT), a partir dos dispositivos estabelecidos na Constituição (DRAIBE; CASTRO; AZEREDO, 1991).

O texto constitucional reforçou também o caráter distributivo e a responsabilidade pública na regulação, na produção e na operação das políticas sociais. O vínculo contributivo como princípio estruturante do sistema foi afrouxado, em favor de uma forma mais abrangente de proteção.

O conjunto de normas inscritas na Constituição de 1988, referentes à política social, redesenha, portanto, de forma substancial, o sistema brasileiro de proteção social, ao ponto de Draibe (1993) sustentar que, a partir dos anos 1990, assistiríamos a um redirecionamento do modelo meritocrático-conservador, no qual foi inicialmente inspirado, para um modelo de proteção social institucional-redistributivo ou mais universalista e equânime, sendo os benefícios sociais não-contributivos a "novidade" das políticas sociais brasileiras desde então.

Mesmo considerando as ações mais efetivas em direção a certa universalização dos direitos sociais brasileiros após a instituição da Seguridade Social no texto constitucional de 1988, tanto Goldani (2004) como Pochmann (2003) sugerem que os brasileiros, de uma maneira geral, ainda não conseguiram alcançar uma cidadania econômica.

Afirma Pochmann (2003) que, a despeito da contínua expansão do gasto social brasileiro, tal esforço orçamentário no enfrentamento da questão social não atinge necessariamente os mais excluídos, de modo que entende não ter havido no Brasil uma constituição de fato de um Estado de Bem-Estar, nos moldes do contexto europeu, pautado pelo assalariamento embasado em direitos coletivos universais. 
Sob este enfoque destaca-se que no caso da previdência, embora tenha havido aumento da cobertura graças à implementação dos regimes de previdência rural e da inclusão de categorias como os trabalhadores autônomos e domésticos, esta ampliação foi limitada no espaço urbano. Isto se deve, fundamentalmente, à exigência de contribuição prévia à concessão de benefícios, em um contexto de grande informalidade das relações de trabalho no país. 


\section{CAPÍTULO III}

\section{PREVIDÊNCIA RURAL NO BRASIL E NO CONTEXTO INTERNACIONAL}

Este capítulo propõe uma exposição mais detalhada sobre a temática de fundo deste trabalho, ou seja, a previdência rural, partindo do estudo dos seus antecedentes históricos e legais até o detalhamento e análise crítica das principais regras de custeio e de benefícios do novel modelo instituído pela Constituição Federal de 1988.

\section{Evolução do sistema de proteção previdenciária ao trabalhador rural}

\subsection{Do início até a fase pré-Constituição Federal de 1988}

A regulamentação do trabalho rural deu-se como parte do processo histórico brasileiro, verificando-se o destaque da cultura agrária desde a colonização do país, que a partir de 1530 passou a ser tomado pelo cultivo da cana-de-açúcar.

Conta Barros Júnior (1981) que, nos primórdios da Independência, em 13 de setembro de 1830, foi sancionada por D. Pedro I aquela que os historiadores apontam como a primeira lei, ainda na vigência da Constituição do Império, versando sobre o trabalho agrário. Apesar de não haver nenhuma referência expressa ao trabalhador rural, regulamentou-se o contrato escrito sobre prestação de serviços celebrado por brasileiro ou estrangeiro, dentro e fora do território imperial, interpretando os estudiosos da época que o diploma legal reportava-se à vida agrária nacional. Entre outras medidas, estabeleceu-se o regime aplicável ao trabalhador faltoso que estaria sujeito pelo emprego da força a indenizar o locatário, podendo, ainda, ser submetido à pena de prisão. 
Sobreveio, então, a lei 108 de outubro de 1837, abarcando os contratos de locação de serviços em que o locador fosse estrangeiro, ainda que a celebração da avença ocorresse no exterior, desde que a sua execução se desse no Brasil.

O primeiro diploma legal que expressamente se referiu à locação de serviços rurais foi o Decreto 2.827, de 15 de março de 1879, fechando-se o ciclo da legislação imperial sobre o trabalho agrícola. O referido Decreto abordava, ainda, demais trabalhos relacionados à agricultura, inclusive as parcerias rurais, surgindo em atenção ao que dispunha o Código Comercial, de 1850, a partir do seu artigo 226, sobre a locação mercantil.

Sublinhe-se, entretanto, que a economia da época ainda era escravagista, não havendo como se falar em proteção ao trabalhador rural, o que não retira a importância do Decreto 2.827 como a primeira lei regulamentadora de trabalho agrícola na seara do direito positivo brasileiro.

A proclamação da República, em 1888, significou a ruptura com o então arcaico modelo imperial. O descompasso verificado na política e forma de organização do Estado teve seus reflexos no direito. Assim, o governo republicano incontinente revogou a legislação imperial através do Decreto 213, de 1890, sem ao menos cuidar de substituí-la por leis novas, o que somente seria providenciado no início do século XX.

Destarte, logo no começo da primeira década daquele século, foram editadas as Leis 1.150 e 1.607, ambas versando sobre a proteção salarial do trabalhador rural, regulamentadas pelo Decreto $n^{\circ}$ 6.437/1907. Estabeleceu-se nesse momento o privilégio dos créditos das dívidas resultantes de salários dos camponeses, vinculados, entretanto, somente à primeira colheita, passando posteriormente a serem classificados como quirografários, ou seja, sem qualquer preferência ou garantia em relação ao seu crédito.

Todavia, os direitos conferidos ao trabalhador rural eram parcos, até porque seu labor era exercido, freqüentemente, sob a forma de servidão.

Aduz Santos (1987, pp. 64 e 65) que 
(...) as relações de trabalho no setor agrícola da economia jamais chegaram a se aproximar das condições da acumulação laissez-fairiana clássica. Se é verdade que se abolira a escravidão, nem por isso a mobilidade do fator trabalho foi totalmente garantida, substituindo a forma de servidão. A penetração das leis de mercado na economia agrária brasileira se fez muito lentamente e em flagrante descompasso com o ritmo de implantação da ordem capitalista na área urbana. A prevalência do laissez-faire é, portanto, restrita à área urbana da sociedade, cujas relações econômicas e sociais deveriam pautar-se pelos princípios que regeram as organizações sociais européias no período que vai do início da industrialização às primeiras leis de regulação social.

(...) a hegemonia ideológica do laissez-faire teve vida curta no Brasil, restrita à área urbana, entre 1888 e 1931, no que concerne à economia, e vulnerada a partir de 1923 no que diz respeito às relações sociais.

O mesmo autor destaca a sindicalização rural, autorizada no início do Século XX, como importante avanço na trajetória de regulamentação do trabalho rurícola.

Trinta anos antes da Constituição de 1934 - a qual, ao mesmo tempo em que reconhecerá a obrigação social do Estado, lhe garantirá o direito de regular o exercício das profissões - entretanto, foi, sem dúvida, passo arrojado, por parte do poder público, reconhecer aos profissionais da agricultura e indústrias rurais o direito de organização e formação de sindicatos, em 1903, seguido pela legislação de 1907, que assegurava o mesmo direito a qualquer categoria profissional.

Ainda comenta Santos (1987) que o impacto dessa legislação provocou importante fissura na ordem jurídico-institucional laissez-fairiana, strictu sensu, ao admitir a legitimidade de demandas coletivas, antes que estritamente individuais. O sindicalismo legal irrompia na vida política brasileira e passava a ser um dos dados "objetivos" da realidade.

Seguindo a ordem cronológica dos eventos, cumpre salientar os avanços no tocante à proteção de acidentes do trabalho, sendo a Lei 3.724 a inaugural sobre infortunísticas, datada de janeiro de 1919. Em seu artigo $3^{\circ}$ estabelece o primeiro passo no sentido de proteger o camponês acidentado, ainda que limitasse a guarida somente àqueles que prestassem serviços "nos estabelecimentos industriais nos trabalhos agrícolas em que se empreguem motores inanimados".

A Lei Eloy Chaves, de 1923, apontada como marco inicial do sistema previdenciário brasileiro, não atendia o trabalhador rural, persistindo a omissão nos anos 1930 quando o sistema de Caixas, por empresa, deu lugar ao de Institutos, por categoria profissional.

Apesar da Constituição Federal de 1934 determinar que todo trabalhador brasileiro teria direito à cobertura da Previdência Social, não atingiu os trabalhadores rurais, pois, ao 
tratar especificamente da proteção previdenciária em seu art. $121, \S 1^{\circ}$, alínea "h", a limita à figura do empregado, a manter o sistema de proteção previdenciária exclusivamente aos trabalhadores formais, a reboque do modelo de conservador-meritocrático inaugurado pelas CAPs.

Com a Reforma Constitucional de 1936, a legislação atribuiu competência exclusiva à União para legislar sobre o Direito do Trabalho retirando dos entes federativos a importância na regulamentação da matéria. Gerou-se, assim, a iniciativa de propostas de um Código Rural, sendo um projeto apresentado à Câmara dos Deputados, em 1937, por Borges de Medeiros e outro em 1942, por Pereira da Silva, sob inspiração de Getúlio Vargas. Outras tentativas nesse sentido seguiram com o anteprojeto de Código Rural em 1951, elaborado por Sílvio da Cunha Echenique (Kerbauy, 2008).

Em 1943, entrou em vigor a Consolidação das Leis do Trabalho (CLT), que não obstante tenha representado conquista significativa para os trabalhadores com a consagração de direitos fundamentais como direito ao salário mínimo (art. 76); direito a férias anuais remuneradas (art. 129, parágrafo único); direito ao aviso prévio (art. 505); direito à aplicação das normas genéricas sobre remuneração (art. 505); excluiu ${ }^{10}$ expressamente os trabalhadores rurais do seu âmbito, nos termos do seu artigo $7^{\circ}$.

A primeira medida voltada para a inclusão do trabalhador rural na Previdência Social, dar-se-ia em 1945, quando Getúlio Vargas assinou a Lei Orgânica de Serviços Sociais (Decreto-Lei $\mathrm{n}^{\mathrm{o}}$ 7.526), com o objetivo de estender os benefícios do seguro social a toda população ativa do país, entretanto, conta Kerbauy (2008), esta primeira tentativa de universalização da previdência brasileira, não chegou a ser implementada.

O histórico legislativo demonstrava, portanto, a necessidade de se proporcionar adequada proteção ao trabalhador rural, abrindo a Constituição Federal de 1946 novos rumos para a regulamentação do trabalho rural. Por conseguinte, inaugurou-se no ordenamento positivo brasileiro referência expressa ao direito do camponês à estabilidade no emprego e ao

\footnotetext{
${ }^{10}$ Contudo, ao longo do seu texto guardam-se alguns preceitos a serem aplicados a esta espécie de trabalhador, como no caso da proteção sindical, a eles estendida por força do artigo 505 da CLT.
} 
recebimento de indenizações de antiguidade, nos casos de dispensa sem justa causa (art. 157, XII).

A Lei 2.613 de 1955 criou o Serviço Social Rural, destinado a prestar assistência às populações rurais, porém somente em meados de 1962, passou a atendê-la de forma considerável.

Embora já constituíssem considerável parcela da população economicamente ativa, tanto os trabalhadores rurais, quanto, na área urbana, as empregadas domésticas e os profissionais autônomos, ficaram desatendidos pela Lei Orgânica da Previdência Social (LOPS), versão bastante revista do projeto de lei n. 3.807 apresentado, em 1947, pelo então deputado Aluísio Alves, cuja principal inovação consistiu na uniformização dos benefícios e serviços prestados pelos Institutos de Aposentadorias e Pensões (IAPs). A lei assegurava o mesmo regime de benefícios, independentemente da categoria profissional de cada um, a todos os trabalhadores regulados pela CLT.

Santos (1987, p. 31) atribui a demora na cobertura à estrutura organizacional destas categorias ao

(...) conformismo rural, até meados da segunda metade da década de 50, assim como a dificuldade de organizar as demandas de duas parcelas ponderáveis da estratificação ocupacional urbana - as empregadas domésticas e os trabalhadores autônomos , em razão de sua fragmentação e dispersão, respondem pelo atraso, ou descuido, da ação protecionista governamental em relação a elas. Pela mesma razão, é a agitação camponesa que se deflagra na segunda metade da década dos 50 que irá provocar a atenção do poder público para os problemas da acumulação e equidade na área rural, refletida na promulgação da Lei 4.214, de 2 de março de 1963, sob a solene denominação do Estatuto do Trabalhador Rural, o qual, não obstante, revelou ser apenas outro exemplo de manipulação simbólica de estatutos legais, uma vez que não lhe foram definidos os meios materiais - financeiros e outros - de operação efetiva.

Comunga da mesma opinião Schwarzer (2000a, p. 06)

No entanto, embora já na Constituição de 1934 estivesse inscrito que todo trabalhador brasileiro possuía direito à proteção da Previdência Social [Malloy (1976)], não houve a extensão da proteção social aos trabalhadores rurais. Entre os vários motivos que poderiam ser suscitados para explicar o fato, o principal parece ser o fato de os trabalhadores rurais, não obstante a população rural constituir a maioria da população brasileira até a década de 60 (ver Tabela 1), não representarem grupo de pressão com capacidade de articulação política e vocalização suficiente a tal ponto que o Estado populista paternalista nele visse um grupo social a ser integrado e cooptado por meio da expansão significativa da cobertura de programas sociais. Esse padrão de expansão da cobertura previdenciária, em círculos 
concêntricos desde o núcleo funcionalmente estratégico aos respectivos modelos de desenvolvimento, relegando os pouco articulados e vocais setores rurais e de serviços urbanos informais, é uma característica geral da expansão histórica da Previdência Social em praticamente todos os países da América Latina [Mesa-Lago (1978)].

No último quarto da década de 1950, este quadro de letargia do setor rural observa mudança. As Ligas Camponesas, a primeira forma mais ampla de movimento social rural, representam uma transformação na capacidade de reivindicação do setor agrário, embora o foco deste movimento não fosse precipuamente a previdência.

Sobre este período escrevem Delgado e Schwarzer (2000, pp. 189 e 190)

\begin{abstract}
Esse cenário começa a mudar, no caso brasileiro, a partir dos anos 50, com a gradativa mobilização dos trabalhadores rurais (Almeida, 1981). Entretanto, o eixo das reivindicações socioeconômicas, no primeiro momento, era a reforma agrária, ao passo que a extensão das demais políticas trabalhistas e sociais, incluindo a Previdência Social, embora por vezes manifesta em congressos da categoria, aparecia como demanda secundária, passando a primeiro plano nos anos seguintes. O crescente grau de organização do setor ficou evidenciado no início dos anos 60 pelo papel das famosas Ligas Camponesas, que sustentaram um movimento amplo de sindicalização rural, no qual a Igreja Católica teve papel protagônico. O Governo Goulart foi sensível a essa mobilização, reconhecendo-as e até estimulando-as. Interessa mencionar que, por exemplo, a CONTAG (Confederação Nacional dos Trabalhadores na Agricultura) foi fundada nesse período, em dezembro de 1963.
\end{abstract}

Faleiros (2000, p. 136) também comenta a tardia inclusão do trabalhador rural e dos empregados domésticos nos benefícios previdenciários sustentando que

(...) o campesinato, isolado e submetido à dominação paternalista da oligarquia rural, constituiu-se na América Latina, no grupo excluído, até muito recentemente, dos seguros sociais, até que seus movimentos tivessem presença na cena política e, na medida em que o capitalismo e o regime assalariado fossem introduzidos no campo. Como o campesinato, os empregados domésticos, integrados e submetidos ao paternalismo familiar, também ficaram excluídos dos seguros sociais.

Neste contexto, somente quarenta anos depois de instituído o sistema previdenciário urbano, tomando como embrião a Lei Eloy Chaves, deu-se inclusão do trabalhador rural na legislação da Previdência Social em 1963, com o Estatuto do trabalhador rural (Lei 4.214), que criou o FUNRURAL, Fundo de Assistência e Previdência do Trabalhador Rural, para cujo custeio foi estabelecida uma contribuição de $1 \%$ sobre o valor da primeira comercialização do produto rural, a ser paga pelo próprio produtor, ou em caso de acordo, pelo adquirente da produção. 
O Estatuto do Trabalhador Rural foi reformulado pelo Decreto-Lei 276, de 28 de fevereiro de 1967, que tentou adequá-lo às suas reais possibilidades. A arrecadação das contribuições foi entregue ao recém-criado Instituto Nacional de Previdência Social (INPS) e o plano de prestações ficou limitado às assistências médica e social, suprindo-se os benefícios em dinheiro. O Decreto-Lei 276 alterou também a sistemática da contribuição, que continuava a ser recolhida como percentual da primeira comercialização do produto rural, mas passava a ser obrigação do adquirente e não mais do produtor, a menos que esse processasse a transformação do próprio produto. Tal medida, afirma Beltrão, Oliveira e Pinheiro (2000) tinha por objetivo facilitar a fiscalização, uma vez que se esperava que a empresa que industrializasse o produto já estivesse vinculada ao sistema previdenciário.

Em que pese estas medidas tenham representado avanço significativo na salvaguarda dos direitos dos rurícolas, instituindo conceitos que futuramente permearam a legislação pátria pertinente ao tema, pontua Schwarzer (2000a, p. 7 e 8):

\begin{abstract}
(...) os autores são unânimes em afirmar que o plano de custeio, baseado principalmente sobre uma contribuição de $1 \%$ sobre o valor da primeira comercialização do produto rural e com recolhimento de obrigação legal do próprio produtor agrícola, não forneceu uma base financeira suficiente à execução do programa, tornando, ademais, a fiscalização e o recolhimento das contribuições absolutamente inviáveis [Malloy (1976) e Oliveira e Bevilaqua (s.d.)]. Afora isso, a administração dos benefícios e a arrecadação das contribuições do Funrural foram repassadas ao IAP dos Industriários (IAPI), que, embora eficiente no que tangia ao cumprimento do seu papel em relação aos trabalhadores industriais, certamente não possuía o mesmo conjunto de incentivos para a gestão do programa rural. Desse modo, a legislação de 1963 foi, na realidade, uma medida de efeitos meramente demonstrativos, sem impacto relevante algum na estruturação de um sistema de proteção social concreto na área rural.
\end{abstract}

Em 1969, através do Decreto-Lei 564, foi criado o plano básico da Previdência Social, voltado em princípio para trabalhadores dos setores agroindustriais e agrícolas mais capitalizados, notadamente, da indústria canavieira. O plano de benefícios era semelhante ao do Estatuto do Trabalhador Rural, com exceção das assistências médica e à maternidade e com a inclusão do auxílio-reclusão. Em 14 de julho de 1969, pelo Decreto-Lei 704, o Plano Básico foi estendido a outras atividades rurais. Todavia, seus objetivos não foram atingidos de maneira satisfatória, levando o governo a buscar novas iniciativas no campo da Previdência Social rural.

A viabilização do regime rural acontece, assim, somente em 1971, através da Lei Complementar $\mathrm{n}^{\mathrm{o}}$ 11. Foi extinto o plano básico e criado o Programa de Assistência ao 
Trabalhador Rural (PRORURAL), a responsabilidade pela execução do programa coube ao também recém criado Fundo de Assistência e Previdência do Trabalhador Rural (FUNRURAL), diretamente subordinado ao então Ministério do Trabalho e Previdência Social e com natureza autárquica. Os benefícios destes programas eras destinados aos trabalhadores rurais assalariados e autônomos do regime de economia familiar e seus dependentes. Os pescadores são incluídos em 1972 e os garimpeiros em 1975.

A partir de 1974, a Lei n. ${ }^{\circ} 6.179$, de 11 de dezembro inclui no elenco de benefícios da Previdência Social rural a Renda Mensal Vitalícia (RMV) para idosos a partir dos 70 anos de idade ou por invalidez para os que não completassem os requisitos estabelecidos para a aposentadoria/pensão, também no valor de meio salário mínimo. No mesmo ano, a Lei n. ${ }^{\circ}$ 6.195, de 19 de dezembro, cria o Seguro Acidentes do Trabalho Rural.

Pontua Berwanger (2008, p. 76) como marcante diferença entre o PRORURAL e o plano anterior, a ampliação do rol de beneficiários, vez que antes eram beneficiários apenas os trabalhadores rurais assalariados

\footnotetext{
$\mathrm{Na}$ expressão "trabalhador rural", passaram a ser contemplados não apenas o empregado, mas também os parceiros, arrendatários, posseiros e pequenos proprietários rurais, desde que não tivessem o auxílio de empregados, ou seja, os que trabalhavam em regime de economia familiar.
}

Os recursos destinados ao custeio do FUNRURAL passaram a provir da contribuição de alíquota de $2 \%$ incidente sobre o valor comercial dos produtos rurais, a encargo do adquirente. Criou-se, ainda, fonte específica para o custeio dos benefícios acidentários, a serem atendidos por contribuição adicional de $0,5 \%$, incidente sobre a mesma base, conforme estabelecido pela Lei 6.195/74. Além disso, uma alíquota de 2,4\% sobre a folha de salários urbana complementava a estrutura de custeio do FUNRURAL.

A criação do FUNRURAL é tratada na literatura como a extensão dos direitos previdenciários aos trabalhadores rurais, isto é, como uma ação estatal de atribuição de status de cidadania aos trabalhadores rurais expresso na política social de previdência que, a partir de então, passam a gozar de determinados benefícios sociais. 
Santos (1987, p. 84) comenta a importância do FUNRURAL sob o plano da cidadania e do potencial redistributivo de renda:

\begin{abstract}
Algumas características importantes distinguem o FUNRURAL do sistema previdenciário urbano. Em primeiro lugar, rompe-se com a concepção contratual da previdência, sendo o programa financiado, por imposto sobre a comercialização dos produtos rurais, e, em parte, por tributação incidente sobre as empresas urbanas. Os trabalhadores rurais não desembolsam nenhuma contribuição direta para o fundo. Ademais, inexiste a partilha profissional, ou ocupacional, do trabalho agrícola, à qual, eventualmente, estivesse associadas pautas de direito diferenciados (...)
\end{abstract}

Com efeito, o programa FUNRURAL pode ser apreciado, política e socialmente, por dois ângulos distintos. Do ponto de vista da eqüidade, é inegável tratar-se de um programa redistributivo que transfere renda das áreas urbanas para as áreas rurais, visto que a tributação que dá origem aos recursos para o programa termina por ser incorporado ao preço dos produtos, consumidos majoritariamente nas áreas urbanas. Mas também se trata de um programa redistributivo entre regiões.

Mas é, sobretudo, conectado, à promoção da cidadania que o FUNRURAL é, potencialmente, mais importante. Rompendo com o conceito de cidadania regulada e com a noção contratual de direitos sociais, o FUNRURAL finca na existência do trabalho, contribuição social básica, a origem da pauta de direitos sociais igualmente básicos.

(...) é no FUNRURAL que o conceito de proteção social, por motivos de cidadania, sendo esta definida em decorrência da contribuição de cada cidadão, à sociedade como um todo, via trabalho, é mais integrado e complexo. Não se trata de distribuição de serviços ou benefícios para fins específicos, como no PIS-PASEP, ou como compensação por perda de emprego, como no FGTS, mas, basicamente, em razão de carências que se geram ao longo da participação do trabalhador no processo produtivo, ou quando dele já não pode mais participar. Trata-se de promover direitos que são direitos do trabalho, simplesmente.

Na mesma linha, a partir da lente de Malloy (1976), observa Schwarzer (2000a, p. 10)

(...) como elemento inovador do Prorural/ Funrural, que ele representou um duplo rompimento com os princípios do seguro social de padrão contributivo bismarckiano, que caracterizaram a história da Previdência Social na América Latina no século XX. Em primeiro lugar, houve a ruptura com a noção de que a um benefício deve corresponder uma contribuição e, segundo, que o benefício resultante deve estar vinculado ao padrão de rendimentos pregressos do segurado. Outro elemento diferenciador consiste no fato de que há, no programa, uma redistribuição de renda no sentido urbano-rural, contra-arrestando, ao menos parcialmente, o subsídio rural-urbano implícito na forma de financiamento dos sistemas urbanos via contribuição sobre a folha salarial, cuja parcela patronal geralmente é repassada para os preços dos bens consumidos também na área rural [Oliveira e Bevilaqua (s.d.) e Malloy (1976)].

Os analistas do período afirmam que a preocupação com a Seguridade Social durante o período autoritário não poder ser encarada como ato progressista do regime de exceção. A rigor, a estrutura criada com o FUNRURAL/PRORURAL atendia ao interesses clientelísticos 
do partido do governo e visava abafar perturbações sociais na área rural. Nesse sentido, Schwarzer (2000a, p. 8):

Curiosamente foi o regime militar brasileiro (1964/84), conservador e autoritário, quem expandiu, de forma inédita na América Latina, a cobertura do sistema previdenciário ao setor rural. Malloy (1976) elenca cinco razões principais para esse comportamento aparentemente paradoxal. Primeiro, que os tecnocratas encarregados da administração do sistema previdenciário identificavam-se, em larga medida, com o mainstream da discussão previdenciária internacional à época, que, orientado por princípios da Organização Internacional do Trabalho (OIT), via na universalização da cobertura um objetivo a ser atingido. Segundo, o temor do regime autoritário em relação a perturbações sociais na área rural - ainda mais que os anos 60 e 70 viram uma política de modernização do setor rural marcada pela mecanização e quimificação das técnicas de cultivo, expansão da grande propriedade e produção de commodities exportáveis, uma reestruturação que significou um alto custo social para a pequena produção rural. Terceiro, a possibilidade de, por meio de um programa social de cunho paternalista e centralmente administrado, aumentar a dependência individual em relação ao Estado e cooptar organizações sociais tais como os sindicatos de trabalhadores ou empregadores rurais. Quarto, há a menção em Malloy a declarações de técnicos governamentais da época, que desejavam evitar a intensificação da migração rural-urbana ao disponibilizar no campo uma infra-estrutura de assistência médica e benefícios monetários, mesmo que precariamente. Por último, o motivo considerado mais importante por Malloy é o papel desempenhado pela doutrina de segurança nacional do governo militar, o qual intencionava, com um programa de integração do setor rural ao projeto de desenvolvimento nacional, manter a "paz social" com a criação de "justiça social".

De toda sorte, a proteção previdenciária criada pelo PRORURAL continuava mitigada e diferenciada em relação à prevista aos demais segurados urbanos, tanto é que não eram assegurados aos rurícolas benefícios da espécie aposentadoria por tempo de serviço e auxíliodoença, entre outros disponíveis aos trabalhadores urbanos.

Nesse sentido dispunha o art. $2^{\circ}$ da Lei Complementar n. ${ }^{\circ} 11$ em comento:

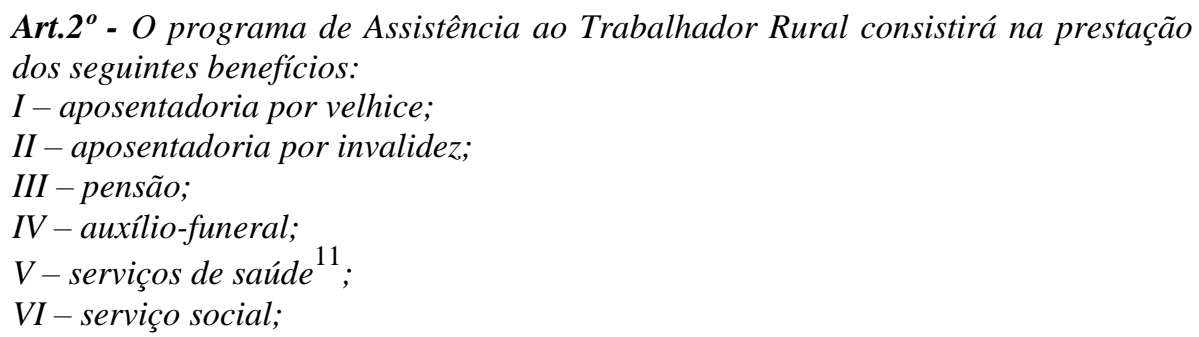

Frise-se que o valor dos benefícios era igualmente reduzido, correspondendo a então denominada aposentadoria por velhice ou por invalidez a uma prestação mensal no valor

\footnotetext{
${ }^{11}$ A assistência médica era administrada via convênios com organizações locais, em especial sindicatos rurais, que estavam explicitamente previstos como parceiros do FUNRURAL na Lei 11/1971 (Art. 28).
} 
equivalente a cinqüenta por cento do salário-mínimo e a pensão por morte devida na fração de trinta por cento, incidente sobre a mesma base.

Afora isso, no PRORURAL somente o chefe de família, em geral o homem, tinha acesso aos benefícios de aposentadoria por idade e por invalidez. As mulheres e os filhos de agricultores não eram considerados segurados, apenas eram beneficiários da pensão por morte.

Até meados de 1977, os segmentos urbano e rural eram assistidos por duas instituições diferentes, a saber: O INPS e o FUNRURAL, entretanto com a criação do SINPAS pela Lei 6.439, os dois segmentos foram unificados e foi atribuído ao INPS a gestão dos beneficiários do INPS e do FUNRURAL, este último extinto pela mesma lei, cabe ressaltar que os planos de benefícios para trabalhadores urbanos e rurais permaneceram distintos e díspares, mas inicia-se uma nova etapa, no sentido de universalização do seguro social no Brasil.

Não obstante a disparidade do amparo entre os dois tipos de trabalhadores, urbanos e rurais, o Fundo de Assistência e Previdência do Trabalhador Rural, ou simplesmente FUNRURAL, sinalizou o progresso na incipiente proteção previdenciária que passou a ser conferida aos rurícolas.

O tratamento desigual no tocante à proteção previdenciária manteve-se até o advento da Constituição Federal de 1988, que finalmente elegeu a uniformidade e equivalência dos benefícios e serviços às populações urbanas e rurais, princípio que foi disciplinado pelas Leis 8.212 e 8.213, ambas de 1991.

\subsection{Pós-Constituição Federal de 1988}

Com a constituição de 1988, foram instituídos novos parâmetros para a população campesina. A promulgação da Constituição Cidadã, como ficou conhecida a $\mathrm{CF} / 88$, inaugura a primeira experiência brasileira de reconhecimento universal de direitos sociais inerentes a cidadania. Ressalte-se que a compreensão de universal aqui diz respeito a estes não mais se reportarem às categorias profissionais, ou quaisquer segmentações corporativas, uma vez que 
desde a década de 1930, direitos sociais eram entendidos como direitos básicos de cidadania, mas não eram universais.

Já em seus artigos introdutórios, a Constituição Federal de 1988 proclama entre os fundamentos e objetivos fundamentais da República Federativa do Brasil a "cidadania" e a "dignidade da pessoa humana" (art. 1º, II e III), bem assim "erradicar a pobreza e a marginalização e reduzir as desigualdades sociais e regionais" (art. $3^{\circ}$, III).

Em seu artigo $6^{\circ}$, a Constituição deliberou que "São direitos sociais a educação, a saúde, o trabalho, a moradia, o lazer, a segurança, a previdência social, a proteção à maternidade e à infância, a assistência aos desamparados, na forma desta Constituição" (destacou-se).

Assim, a previdência foi instituída como um direito de todos os brasileiros, a ser garantido por meio da Seguridade Social, assim disposta no art. 194 da Carta: "A Seguridade Social compreende um conjunto integrado de ações de iniciativa dos poderes públicos e da sociedade, destinadas a assegurar os direitos relativos à saúde, à previdência e à assistência social”.

Acrescente-se que os incisos I e II do parágrafo único do artigo 194 da Constituição estabeleceram que a Seguridade Social deveria ser organizada com base na "universalidade da cobertura e do atendimento" e na "uniformidade e equivalência dos benefícios e serviços às populações urbanas e rurais". A intenção seria de resgatar a dívida histórica com o trabalhador rural, visto que desde o início da sua regulamentação a proteção previdenciária privilegiara o trabalhador urbano, entrementes, o Brasil ser à época um país predominantemente rural.

Em seu artigo 195, $\S 8^{\circ}$, a Constituição Federal definiu o tipo de relação que os trabalhadores rurais com atividade econômica familiar teriam com a Seguridade Social: “O produtor, o parceiro, o meeiro e o arrendatário rurais, o garimpeiro e o pescador artesanal, bem como os respectivos cônjuges, que exerçam suas atividades em regime de economia familiar, sem empregados permanentes, contribuirão para a Seguridade Social mediante a aplicação de uma alíquota sobre o resultado da comercialização da produção e farão jus aos benefícios nos termos da lei”. 
Este dispositivo estabeleceu que os trabalhadores rurais enquadrados na categoria dos segurados especiais estão exonerados da obrigatoriedade de contribuir para o custeio da previdência rural, na medida em que ficou estabelecido que o aludido recolhimento deve ser feito pelo adquirente da comercialização de produtos rurais, mediante o percentual de $2,1 \%$, incidente sobre a receita bruta dessa comercialização, sendo $0,1 \%$ destinado ao financiamento das prestações por acidente do trabalho (art. 25 da Lei n. ${ }^{\circ}$ 8.212/1991).

Delgado e Cardoso (1999), elencam as principais mudanças normativas ocorridas na previdência rural a partir da CF de 1988: equiparação de condições de acesso para homens e mulheres, pois o regime anterior assegurava este acesso apenas para o "chefe" ou "cabeça" do casal, geralmente, o marido; redução em cinco anos do limite de idade para aposentadoria por idade que passou a ser de 60 (sessenta) anos para homem e 55 (cinqüenta e cinco) anos para mulher; estabelecimento de um piso de aposentadorias e pensões em um salário mínimo, o regramento anterior fixava percentual de $50 \%$ e de $30 \%$ de um salário mínimo para aposentadoria e pensões por morte, respectivamente.

Em 1991, foi aprovado o Plano de Benefícios do RGPS, Lei $n^{\circ}$. 8.213, o qual definiu as seguintes categorias ou espécies de segurados do Regime Geral de Previdência Social:

Empregados - entendido como aquele que presta serviço de natureza urbana ou rural à empresa, em caráter não eventual, sob sua subordinação e mediante remuneração, inclusive quando o dirigente for empregado da empresa.

Empregado doméstico - entendido como aquele que presta serviço de natureza contínua a pessoa ou família, no âmbito residencial desta, em atividades sem fins lucrativos.

Contribuinte individual - entendido como aquele que presta serviços de natureza urbana ou rural, em caráter eventual, a uma ou mais empresas, sem relação de emprego; ou, aquele que exerce, por conta própria, atividade econômica remunerada de natureza urbana, com fins lucrativos ou não.

Trabalhador avulso - entendido como aquele que presta a uma ou mais empresas, sem vínculo empregatício, serviços de natureza urbana ou rural com intermediação de sindicatos ou de órgãos gestores de mão de obra - normalmente portuários.

Segurado especial o produtor, o parceiro, o meeiro e o arrendatário rural, o pescador artesanal e o assemelhado, que exerçam essas atividades individualmente ou em regime de economia familiar, ainda que com auxílio eventual de terceiros, bem como seus respectivos cônjuges ou companheiros e filhos maiores de 16 anos de idade ou a eles equiparados, desde que trabalhem, comprovadamente, com o grupo familiar respectivo.

Segurado facultativo: sua participação é voluntária e corresponde aos indivíduos com 16 anos ou mais de idade que se filiem ao RGPS, mediante contribuição, desde que não estejam exercendo atividade remunerada que os enquadrem como segurados obrigatórios ou estejam vinculados a outro regime de Previdência Social. 
Em 2008, a Lei n. ${ }^{\circ}$ 11.718, de 20 de junho de 2008, conferiu mais clara e ampla definição de segurado especial, autorizando o uso eventual de empregados, definindo o tamanho limite da propriedade rural e expondo situações que não descaracterizam a qualidade de segurado especial do rurícola.

De acordo com a nova definição legal, segurado especial é a pessoa física residente no imóvel rural ou em aglomerado urbano ou rural próximo a ele que, individualmente ou em regime de economia familiar, ainda que com o auxílio eventual de terceiros, na condição de: (a) produtor, seja proprietário, usufrutuário, possuidor, assentado, parceiro ou meeiro outorgados, comodatário ou arrendatário rurais, que explore atividade: a.1) agropecuária em área de até 4 (quatro) módulos fiscais; a.2) de seringueiro ou extrativista vegetal que exerça suas atividades nos termos do inciso XII do caput do art. $2^{\underline{0}}$ da Lei $\mathrm{n}^{\mathrm{o}}$ 9.985, de 18 de julho de 2000, e faça dessas atividades o principal meio de vida; (b) pescador artesanal ou a este assemelhado que faça da pesca profissão habitual ou principal meio de vida; e (c) cônjuge ou companheiro, bem como filho maior de 16 (dezesseis) anos de idade ou a este equiparado, do segurado especial, que, comprovadamente, trabalhem com o grupo familiar respectivo.

Com bem observa Schwarzer e Constanzi (2009, p. 172), a Lei n ${ }^{\mathrm{o}} 11.718 / 2008$, promoveu importante atualização conceitual da Previdência Rural às transformações pelas quais passou a agricultura familiar ao longo da década de 90 e dos anos 2000. Para estes autores

\footnotetext{
A referida atualização irá, tanto ajudar a garantir direitos e aumentar a formalidade rural, como também aparar arestas que sua defasagem criava no atendimento dos trabalhadores do campo.

Com esta atualização dos conceitos de segurado especial e da agricultura familiar, passou a haver o reconhecimento da "pluriatividade" do referido regime, ou seja, o fato de que os estabelecimentos, embora não deixem de caracterizarem-se como rurais e terem a agricultura como atividade principal, agregam valor e trazem novas fontes de renda suplementares à ocupação principal.

Ademais, foi prorrogado o prazo que permitia aos trabalhadores rurais, empregados e contribuintes individuais, requererem aposentadoria por idade, no valor de um salário mínimo, mediante a comprovação do exercício de atividade rural até dezembro de 2010.

Tal medida visa garantir o direito à obtenção da aposentadoria desses trabalhadores que já completaram ou estão prestes a completar a idade para obtenção do benefício previdenciário. A nova legislação vai além, ao permitir uma contagem de tempo especial do período de contribuição desses trabalhadores rurais até dezembro de 2020, concomitantemente à adoção de medidas que buscam uma maior formalização das relações de trabalho no campo, como o contrato de trabalho de curta duração entre pessoas físicas, que responde a uma demanda do Fórum Nacional de Previdência Social.
} 
A inovação legislativa teve o mérito de oferecer parâmetros mais objetivos para a caracterização do segurado especial, inclusive remodelando o sistema de inscrição deste segurado na Previdência Social, que até então, no mais das vezes, só se apresentava ao sistema no momento de requerer alguma prestação previdenciária.

É importante destacar neste ponto o comentário de Campos (2006, p. 8-9) de que, atualmente, não há certeza sobre o número exato de segurados especiais no Brasil, porque “estes só são identificados no momento em que requerem benefícios da previdência rural (aposentadorias, pensões, auxílios etc.). Antes desse momento, por falta de um sistema de identificação (que permita o cadastramento e a emissão de documentação), a previdência rural sequer tem o conhecimento do número literal de segurados especiais".

Uma vez desobrigado de contribuir financeiramente para o sistema, o requisito a ser exigido do segurado especial para a percepção de benefícios previdenciários - que são os mesmos oferecidos à clientela urbana, exceto a aposentadoria por tempo de contribuição, salvo se o segurado especial verter contribuições regulares na forma de contribuinte facultativo - limitou-se apenas a comprovação do exercício da atividade rural, o que, não transmuda o sistema em assistencial, pois esta espécie de proteção está vinculada apenas à necessidade ou carência do potencial beneficiário, diferente do sistema protetivo previdenciário que está vinculado ao exercício do trabalho.

Enquanto sistema protetivo previdenciário, o acesso aos benefícios da previdência rural decorre do trabalho e visa a assegurar renda substitutiva em razão de incapacidade laboral. Os benefícios assistenciais decorrem da necessidade, e são concedidos mediante critérios que diferenciam os indivíduos necessitados no conjunto da população.

Naturalmente, para atender aos trabalhadores rurais, a previdência não pode perder a referência das condições econômicas e do mercado de trabalho no campo, onde se constatam inúmeras relações de trabalho não-assalariadas; expressiva presença de pequenos produtores, arrendatários e meeiros; processos econômicos baseados em relações familiares; e onde coexistem relações mercantis mais avançadas, com produções para o autoconsumo, associativismo, cooperativismo e troca. 
Nos casos em que há relações assalariadas, há contribuições individuais, o que também vale para os empregados formais rurais. Para os demais trabalhadores rurais que produzem em regime de economia familiar, ou mesmo em regime de economia individual para subsistência, é prevista outra forma de contribuição, calculada sobre o valor da produção comercializada. Então, existem diferentes formas de contribuição previdenciária, sendo algumas de responsabilidade do segurado e outras de responsabilidade do comerciante que adquire a produção. Acrescentamos que a contribuição patronal do setor agropecuário também se faz sobre a comercialização da produção.

Como a responsabilidade contributiva recai sobre terceiros, para a maioria dos segurados não haverá necessidade de comprovar uma contribuição direta, mas apenas o exercício da atividade rural.

$\mathrm{Na}$ área urbana não é assim. Os segurados precisam comprovar a existência de contribuições relativas à renda do próprio trabalho, sejam assalariados ou não. Trata-se de uma obrigação cumprida diretamente pelo contribuinte individual ou por responsáveis tributários, no caso dos empregados, cooperativados etc.

Desta forma, na área rural, a previdência inovou ao permitir uma universalidade de acesso ao benefício, o que infelizmente ainda não ocorre no setor urbano. O mais próximo que se avançou nessa questão foi a inserção, na Constituição Federal, da previsão do Sistema de Inclusão Previdenciária, para o trabalhador de baixa renda e para os que sem renda própria se dediquem à produção no âmbito de sua própria residência ${ }^{12}$.

Essas novas regras provocaram efetivo impacto social e econômico, aumentando expressivamente em poucos anos o grau de cobertura do sistema sobre o conjunto dos

\footnotetext{
${ }^{12}$ A partir do Decreto 6.042/2007, passou a vigorar o Plano Simplificado de Previdência Social - PSPS, mecanismo que visa promover a inclusão previdenciária do trabalhador de baixa renda, mediante a redução da alíquota de contribuição de $20 \%$ para $11 \%$. Podem optar pelo novo plano, a qualquer tempo: o contribuinte individual que trabalha por conta própria (autônomo), contanto que não tenha relação de trabalho com empresa ou equiparada; o contribuinte individual - empresário ou sócio de empresa - cuja receita bruta anual, no anocalendário anterior, seja de até R $\$ 36$ mil; e, o contribuinte facultativo (por exemplo: donas de casa, estudantes e pessoas acima de 16 anos, não remunerados). Não pode fazer a opção pela contribuição reduzida o contribuinte individual prestador de serviço (pessoa física que presta serviços a pessoa jurídica ou cooperativa). $\mathrm{O}$ valor do salário-de-contribuição é limitado ao salário mínimo. O segurado terá direito a todos os benefícios previdenciários que cabem ao contribuinte individual e ao facultativo, salvo a aposentadoria por tempo de contribuição, a não ser que o segurado complemente a contribuição mensal mediante o recolhimento de mais nove por cento, acrescido de juros.
} 
domicílios rurais e elevaram substancialmente a participação da renda previdenciária na renda familiar rural.

O incremento da cobertura previdenciária rural deu-se com maior intensidade logo depois do advento da Lei n. ${ }^{\circ} 8.213 / 91$, entre os anos de 1991 a 1994, quando se verificou crescimento de aproximadamente $50 \%$ nos números de beneficiários da clientela rural, passando-se de um total de 4,11 milhões de benefícios em 1991 para 6,48 milhões em 1994. Afirma Schwarzer (2000b), que, desde 1994, o estoque de benefícios tem-se mantido em patamar constante, onde a maturação demográfica da população potencialmente beneficiária pareceu estar determinando um leve aumento do número de benefícios por idade e de pensões mantidas até 1997, contrabalançado pelo gradual arrefecimento do número de benefícios assistenciais rurais não mais concedidos desde 1995 (neste caso a estatística capta apenas RMVs, uma vez que os amparos assistenciais da Loas estão contabilizados fora do subsistema rural).

Entre os anos de 1993 a 2009, a clientela rural no Brasil cresceu, de 5,3 para 8 milhões de beneficiários da Previdência Social. O Gráfico 1 demonstra a evolução da quantidade de benefícios previdenciários e assistenciais (LOAS) concedidos pela no intervalo de 2001 a 2009.

\section{Gráfico 1}

Quantidade de Benefícios Concedidos pela Previdência Social (2001 a 2009) acumulado até dezembro (em milhões de benefícios)

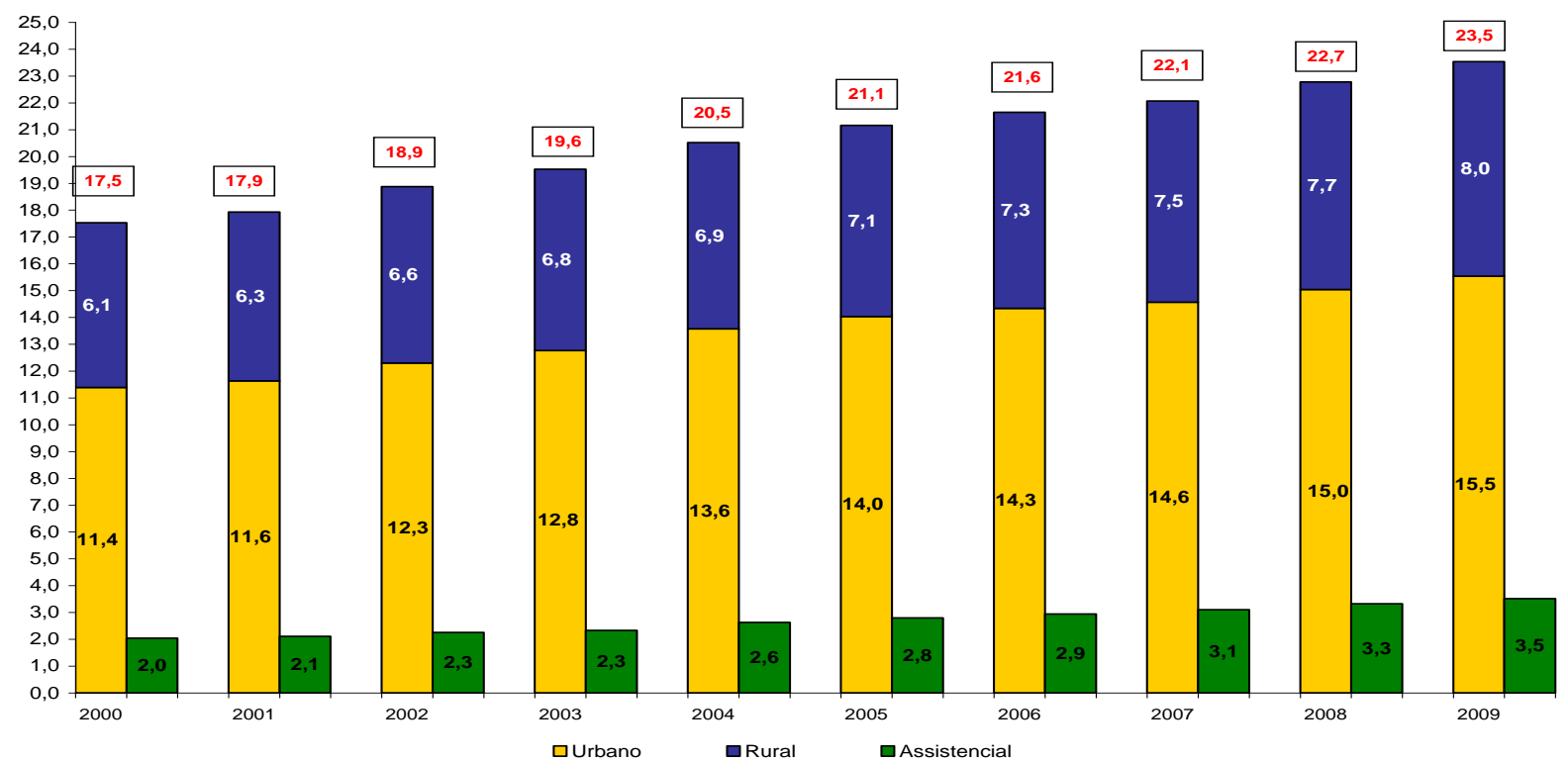

Fonte: Anuário Estatístico da Previdência Social - AEPS e Boletim Estatístico da Previdência Social - BEPS. Elaboração: SPS/MPS. 
Vale compreender que a despeito da Seguridade Social ter entre os seus objetivos a universalidade da cobertura e do atendimento (CF, art. 194, I), o subsistema previdenciário instituído pela $\mathrm{CF} / 88$ permanece essencialmente contributivo e de filiação obrigatória, tanto é que é regulado por critérios que lhe preservem o equilíbrio financeiro e atuarial (CF, art. 201, caput, em redação determinada pela EC n. ${ }^{\circ}$ 20, de 15 de dezembro de 1998).

É dizer, ressalvando a figura do seguro especial, as demais espécies de segurados previdenciários - inclusive, o trabalhador rural que não se enquadre no conceito legal de segurado especial, como é o caso do empregado rural da agroindústria que recolhe contribuição da mesma forma que o faz o empregado com vínculo de trabalho urbano - para terem acesso aos serviços e prestações previdenciárias permanecem obrigados a não apenas comprovarem o exercício de atividade remunerada formal, mas também a verterem contribuições diretas ao sistema, na forma do seu respectivo enquadramento legal: empregado, trabalhador avulso, empregado doméstico ou contribuinte individual.

A respeito da nova dinâmica constitucional são esclarecedoras as considerações de Rangel et al (2009, p. 55):

Esse último objetivo, que está presente no texto original da Carta de 1988, suscita grandes debates sobre a dualidade do papel da Previdência Social em nosso país. Mais especificamente, o debate entre o caráter de seguro versus seguridade. Tal debate origina-se pelo fato de que, na previdência rural, o segurado especial pode exercer seus direitos sociais previdenciários comprovando atividade laborativa no campo. Contudo, no meio urbano - ou mesmo no agrobusiness - o trabalhador precisa comprovar tempo de contribuição ao Sistema Previdenciário.

Ora, se a Previdência Social tem por um de seus objetivos a universalidade da inclusão e do atendimento, a necessidade de contribuição pode ser interpretada como contradição intrínseca à $\mathrm{CF} / 88$, ainda mais que grande segmento populacional pode exercer seus direitos comprovando apenas tempo de trabalho, não tempo de contribuição. Não obstante, há de se compreender que a diferença de tratamento que parece ser favorável aos trabalhadores rurais existe, pois este trabalho além de penoso, desgastante, e de não ter necessariamente objetivos de lucro, também encerra certas características de garantia de segurança alimentar. Além disso, em perspectiva de comparação internacional, os principais sistemas de previdência subsidiam suas populações rurais (SCHWARZER, 2000), ou seja, esta configuração não é invenção brasileira.

Já a previdência urbana deve ter seu objetivo de universalidade compreendido como inexistência de restrições à filiação de qualquer grupo ao sistema, desde que comprovada a contribuição. E o papel de garantia da universalidade da inclusão deve ser observado por meio de políticas de incentivo à filiação de grupos com baixa capacidade contributiva, não necessariamente pela garantia de direitos sem necessidade de obrigações, em contrapartida. Portanto, se na previdência rural o direito social previdenciário tem como contrapartida a comprovação do tempo de trabalho no campo, no meio urbano a contrapartida deve ser o tempo de contribuição. 
Sintetizando, o caráter contributivo financeiro do Sistema Previdenciário brasileiro vale para todos, menos os segurados especiais. Para estes, por terem características de trabalho e papel social específicos, deve ser-lhes garantido o direito à Previdência Social assentado nos princípios da Seguridade Social.

\section{Financiamento da Previdência Social Rural}

Primeiro, deve-se ter claro que a previdência rural integra o sistema previdenciário nacional, o qual, por sua vez, constitui subsistema da Seguridade Social (CF, art. 194). É dizer: não mais existe distinção orgânica entre a previdência do trabalhador rural e a do trabalhador urbano ambas integrando o RGPS.

Assim, se a previdência rural está contida na Seguridade Social, logo a receita mantedora do ramo previdenciário (urbano e rural) advém das fontes financiadoras deste conjunto articulado de ações e iniciativas dos Poderes Públicos e da sociedade explícitas no art. 195 da CF:

Art. 195. A Seguridade Social será financiada por toda a sociedade, de forma direta e indireta, nos termos da lei, mediante recursos provenientes dos orçamentos da União, dos Estados, do Distrito Federal e dos Municípios, e das seguintes contribuições sociais:

I - do empregador, da empresa e da entidade a ela equiparada na forma da lei, incidentes sobre: a) a folha de salários e demais rendimentos do trabalho pagos ou creditados, a qualquer título, à pessoa física que lhe preste serviço, mesmo sem vínculo empregatício; b) a receita ou o faturamento; c) o lucro;

II - do trabalhador e dos demais segurados da Previdência Social, não incidindo contribuição sobre aposentadoria e pensão concedidas pelo regime geral de Previdência Social de que trata o art. 201;

III - sobre a receita de concursos de prognósticos.

IV - do importador de bens ou serviços do exterior, ou de quem a lei a ele equiparar.

Perceba-se que a diversidade da base de financiamento da Seguridade Social é inspirada no próprio texto constitucional que prescreve "art. 194. Compete ao poder público, nos termos da lei, organizar a Seguridade Social, com base nos seguintes objetivos: (...) VI. diversidade da base de financiamento.

Portanto, embora, por expressa imposição do art. 167, XI, da CF/88, seja verdade que as contribuições sociais do empregador e do trabalhador sobre o salário constituem receitas vinculadas (não podem ser utilizadas para outro fim) às despesas da Previdência Social, não é 
verdade que esta seja a única fonte de receita deste subsistema da Seguridade Social, o qual, nos termos do art. 195 acima transcrito, tem diversidade de fontes.

Ressalta Gentil (2006), que a diversificação das fontes de arrecadação foi uma conquista de grande importância, porque a previdência financiada unicamente pela folha de salários entrou em crise nos anos 80, quando a economia brasileira entrou em recessão e o emprego desabou. O crescimento do desemprego, a queda do rendimento médio real dos assalariados e o aumento do número de trabalhadores sem vínculo formal de trabalho mostraram a vulnerabilidade de um sistema de proteção social financiado exclusivamente por contribuições sobre a folha de salários. Em 1988, para alguns dos que participavam da elaboração da nova Constituição Federal e defensores da previdência pública, aquele era o momento, não de aumentar a arrecadação, mas de reduzir a dependência de receita às oscilações do ciclo, uma vez que a massa salarial é a variável que mais se contrai nos períodos de redução dos níveis de atividade econômica.

Destarte, embora seja muito comum o estudo do financiamento da previdência rural a partir do resultado das contribuições sociais (tributos) vertidas especificamente pelos contribuintes rurais (empregadores e trabalhadores), e desta ótica invariavelmente emerge a conclusão de que o subsistema previdenciário rural é fortemente deficitário, a verdade é que o arranjo jurídico-constitucional em nenhum momento enseja esta distinção entre as fontes de custeio, as quais foram destinadas pelo constituinte originário para a cobertura da Seguridade Social como um todo ${ }^{13}$, incluindo-se, portanto, indistintamente as ações de iniciativa dos Poderes Públicos e da sociedade, destinadas a assegurar os direitos relativos à saúde, à previdência e à assistência social.

Partindo desta premissa, concordarmos com o estudo de Gentil (2006, p. 47) que demonstrou não haver déficit e sim superávit nas contas da Seguridade Social. E se não há déficit no sistema maior (Seguridade Social) não poderá haver em seus subsistemas, entre os quais o previdenciário (rural e urbano).

\footnotetext{
${ }^{13}$ A única vinculação das fontes de custeio do art. 195 é a advinda da Emenda Constitucional n. ${ }^{\circ}$ 20, a qual, ao introduzir o inciso X, no art. 167, da CF, vedou a utilização dos recursos provenientes das contribuições de que trata o art. 195, I, $a$, e II (pagas pelo empregador sobre folha de salários e pelo trabalhador também sobre sua verba salarial), para a realização de despesas distintas do pagamento de benefícios do RGPS.
} 


\section{Quadro 1}

RESULTADO DA SEGURIDADE SOCIAL

2000 a 2006

valores correntes em $\mathrm{R}$ S milhōes

\begin{tabular}{|c|c|c|c|c|c|c|c|}
\hline & 2000 & 2001 & 2002 & 2003 & 2004 & 2005 & 2006 \\
\hline \multicolumn{8}{|l|}{ RECEITA ${ }^{(1)}$} \\
\hline CONTRIBUICÁO PIINSS & 55.715 & 61.060 & 71.028 & 80.730 & 93,765 & 108.434 & 123520 \\
\hline COFINS & 38.707 & 45.507 & 50.913 & 58216 & 77.593 & 87.902 & 92.475 \\
\hline CPMF & 14.395 & 17.157 & 20.265 & 22.997 & 26.340 & 29.230 & 32.090 \\
\hline CSLL & 8.750 & 9.016 & 12.507 & 16.200 & 19.575 & 26.323 & 28.116 \\
\hline RECEITA DE CONCURSOS DE PROGNOSTICOS & 923 & 1.028 & 1.062 & 1.276 & 1.450 & 1564 & 1.410 \\
\hline PISIPASEP(2) & 5.791 & 6.700 & 7.498 & 10,011 & 11.650 & 13228 & 14.566 \\
\hline TOTAL DA RECEITA & 124.281 & 140.468 & 163.273 & 189.420 & 230.373 & 266.681 & 292.177 \\
\hline \multicolumn{8}{|l|}{ DESPESA ${ }^{[3]}$} \\
\hline ASSISTENCIA SOCLAL & 4.442 & 5.298 & 6.513 & 8.416 & 13.863 & 15806 & 21551 \\
\hline SAUDE & 20.270 & 23.634 & 25.435 & 27.172 & 32.973 & 36.483 & 39.736 \\
\hline PREVDENCIA ${ }^{(4)}$ & 67.544 & 77.584 & 89.300 & 109.525 & 125.901 & 144.918 & 168.009 \\
\hline ABONO E SEGURO DESEMPREGO & 4.636 & 5.635 & 7.062 & 8.074 & 9.471 & 11.337 & 11927 \\
\hline TOTAL DA DESPESA & 96.892 & 112.151 & 128.390 & 153.287 & 182.208 & 208.544 & 241.223 \\
\hline RECEITA - DESPESA & 27.389 & 28.317 & 34.883 & 36.133 & 48.165 & 58.137 & 50.954 \\
\hline RECEITA COM DRU ${ }^{(3)}$ - DESPESA & 13.675 & 12.435 & 16.434 & 14.395 & 20.844 & 26.488 & 17.222 \\
\hline
\end{tabular}

Eaboraçăo própria.

Fontes. Receta da Seguridade Social - Ministério da Fazenda, Receita Federa, Estudos Tributánios -

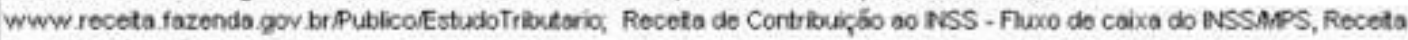

Previdenciéria Líquida.

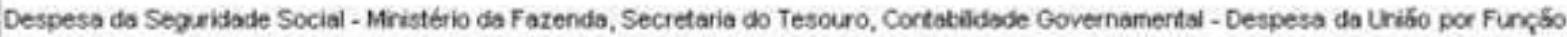
www sth tazenda gov br

(1) Exclue a Cortribuiç5o á Sequridade Social do Servidor Pútbico - CSSS e a contribuiçáo ao custeio de pensö́es

miltares.

(2) helui apenas $60 \%$ do recella con PIS e PASEP, Os $40 \%$ restartes s6o destinados $\infty$ BNDES - www sth fazenda gow br.

estatistica, conta governamertal, recelta de contribucicío.

(3) Despesa liquidsdo por Funçáo, inclusive pessoal o divida. Seguro-desenprego é da funçáb Trabsho, mas fol inckido por ser

un evento da seguridade social Exciuidas as despesas com FAT

(4) Excelé os gastos com instivos do Regime Prócrio do Previdencia dos Servidcres (PopS) e inativos miltares -

www planejanerto gov br, orçanento, estatisticas orçanertarias, evoluçáo das despesas socias - por funçăo

(5) Receta tota deduzida da DexU (Desvinculaçáo das Recetas da Uniáo no valor de 20\%). Obs: A Cortribuiçá para a Previdência Social nắo está suieta a DFu.

O vaior da despesa permanece o mesmo no cilculo do resutado considerando a DRU.

Dodas de seguro-desenprego em www sth fazenda gov br, estatistica, resutado do tesouro nacional, resutado primário

Receita de concursos de prognósticas en www stn tazenda gov bx, estatistica, contab governamertal, receita de cortribuiç. 60

Fonte: Gentil, 2006, p. 47.

Veja-se que o orçamento da Seguridade Social é autônomo, não se confundindo com o orçamento do Tesouro Nacional, conforme previsto no inciso III do $\S 5^{\circ}$, do art. 165 , da $\mathrm{CF} / 88$. Por ser assim, as contribuições arrecadadas com fundamento no art. 195 da Constituição ingressam diretamente nesse orçamento, não constituindo receita do Tesouro Nacional, cuja parte no bolo reside no orçamento fiscal ${ }^{14}$.

\footnotetext{
${ }^{14}$ Excetuando a regra da autonomia dos orçamentos da União, desde de 1994 o sucessivos governos têm criado mecanismos que permitem que parte das receitas de impostos e contribuições não seja obrigatoriamente destinada a determinado órgão, fundo ou despesa a que estava vinculado. Atualmente, este mecanismo, antes chamado de Fundo Social de Emergência (FSE) e de Fundo de Estabilização Fiscal (FEF), é denominado de Desvinculação de Receita da União (DRU), estando em vigor por força da $\mathrm{EC}^{\circ} 56$, de 2007 , que a prorrogou nos mesmos termos da $\mathrm{EC} \mathrm{n}^{\circ} 42$, de 2003. O dispositivo desvinculou de órgão, fundo ou despesa, até 31 de dezembro de 2011, 20\% da arrecadação de impostos, contribuições sociais e de intervenção no domínio econômico, já instituídos ou que vierem a ser criados, seus adicionais e respectivos acréscimos legais. A
} 
Entre as conclusões de Gentil (2006), merecem destaque:

O desequilíbrio orçamentário está no orçamento fiscal e não no orçamento da Seguridade Social ou no orçamento da Previdência Social;

A seguridade não recebe recursos do orçamento fiscal, ao contrário, parte substancialmente elevada de seus recursos financia o orçamento fiscal;

Não é a previdência que causa problemas de instabilidade econômica e crise de confiança nos investidores, mas ao contrário, é o orçamento da seguridade que tem servido para respaldar a política econômica de gastos financeiros elevados, resultado da prática de taxas de juros muito altas.

É a política econômica que atinge a Seguridade Social, precarizando serviços essenciais à sobrevivência da população.

De qualquer sorte, embora não haja previsão legal de que se devam fazer contas em separado para os subsistemas que integram a Seguridade Social, muito menos contas em separado dentro de um mesmo subsistema previdenciário - o que se dá ao distinguir a arrecadação proveniente dos setores urbano e rural - com a intenção de melhor expor os principais aspectos que circundam a previdência rural, vale analisar a contribuição oriunda das relações econômicas no campo, para tanto se adota a metodologia de Delgado e Castro (2003, p. 09) que estruturaram os mecanismos de financiamento do subsistema de previdência rural, em três fontes próprias de arrecadação, a saber:

a) contribuição sobre a comercialização da produção primária do segurado especial, originalmente, e depois de pessoas físicas e jurídicas rurais $\left(\mathrm{CF}\right.$, art. 195, $\left.\S 8^{\circ}\right)$;

b) acesso à contribuição urbana para Previdência Social como forma suplementar para financiar a Necessidade de Financiamento da Previdência Rural;

c) exaurida a fonte mencionada no item "b", recorre-se às contribuições parafiscais da Seguridade Social (Cofins, Contribuição sobre o Lucro Líquido e CPMF, além de outras fontes de menor peso).

Os mesmo autores (p. 09-10) apontam que cada uma dessas fontes vem sofrendo modificações de alíquotas e da própria conceituação de contribuinte, desde sua implantação a partir da Lei de Custeio da Previdência (Lei no 8.212, de junho de 1991), passando por sucessivas alterações.

a) O segurado especial, em todas as mudanças na legislação desde 1991, somente foi taxado sobre a comercialização primária da produção, e sua alíquota foi de 3,0\%, em 1991 (Lei no 8.212/91), mas desde a promulgação da Lei no 8.861, de 1994, é de

princípio, das fontes da Seguridade Social só está livre da DRU as contribuições do art. 195, I, $a$, e II (pagas pelo empregador sobre folha de salários e pelo trabalhador também sobre sua verba salarial). 
$2,2 \%{ }^{15}$. Houve tentativa de instituir contribuição independente e individual ao segurado especial, mas o próprio governo recuou: retirou o projeto do Executivo, apresentou ao Congresso em meados de 1999 e retirou no fim desse mesmo ano.

b) A Contribuição Patronal Rural, que originariamente, de acordo com a Lei de Custeio, incidia sobre a folha de pagamento, passou a incidir, tanto para pessoas físicas (em 1993) quanto para pessoas jurídicas (Lei no 8.870/94), sobre a comercialização da produção, com alíquotas máximas variando nesse período entre $2,2 \%$ e $2,7 \%$. Atualmente, a partir de Lei no 10.255 , de junho de 2001, a agroindústria passou (ou voltou) a contribuir sobre a comercialização para a Previdência Rural, com alíquota específica de $2,5 \%{ }^{16}$.

c) A contribuição sobre folha de pagamento salarial ficou restrita aos empregados (não aos empregadores) do setor rural formal e aos autônomos. Ambos não são segurados especiais. Essa fonte é financeiramente insignificante, (...), e legalmente os seus segurados não são os segurados especiais da Previdência Rural. Contudo, evidenciaremos essa informação para efeito de comparações do próprio leitor, já que o dado reflete o verdadeiro tamanho do setor formal rural (carteira de trabalho assinada), em contraposição ao setor informal, que para a Previdência seria o regime de economia familiar.

d) A principal fonte de financiamento rural, a contribuição patronal urbana, não mais aparece em lei, como por ocasião da criação do Prorural-Funrural (1971), quando era explícita a vinculação de um adicional de 2,4\%, acrescido à alíquota global dos empregadores urbanos para compor a base de recursos do Funrural.

Completam Delgado e Castro (2003) que mesmo inexistente na norma legal, a vinculação de recursos da contribuição urbana continua presente, embora implícita, no orçamento da Previdência Social. Tendo havido aumento expressivo da despesa com benefícios e a não-criação de novas fontes de financiamento, a vinculação da contribuição urbana continuou implicitamente a financiar parte da despesa da área rural, ainda que sem possibilidade de equacioná-la. Isso porque, sendo o fluxo orçamentário do subsistema rural estruturalmente deficitário, como demonstraremos a seguir, o seu financiamento dependerá em primeira instância da arrecadação urbana, e somente quando esta se revelar insuficiente é que será requerida a complementação dos recursos específicos da Seguridade Social.

A fundamentar o "déficit" entre as despesas com a previdência rural e a correspectiva arrecadação proveniente da atividade produtiva do campo, aponta-se que enquanto na área urbana a arrecadação líquida praticamente empata com o valor total de benefícios pagos, na área rural a arrecadação cobre em média um décimo (1/10) da despesa com benefícios emitidos, a ensejar financiamento, a princípio pelo sistema previdenciário urbano, em percentual superior a $1 \%$ do PIB nacional, como ilustram os Gráficos 2 e 3.

\footnotetext{
${ }^{15}$ A partir do advento da Lei n. ${ }^{\circ} 10.256$, de 9 de julho de 2001, a alíquota é de $2,1 \%$, sendo $2 \%$ destinado à Seguridade Social e $0,1 \%$ destinado a financiamento das prestações por acidente do trabalho.

${ }_{16} \mathrm{Na}$ verdade, a alíquota é de 2,6\%, sendo 2,5\% destinado à Seguridade Social e $0,1 \%$ para o custeio da aposentadoria especial e do Seguro de Acidente do Trabalho.
} 


\section{Gráfico 2}

Evolução da Arrecadação, Despesa de Benefícios e Necessidade de Financiamento do RGPS - RURAL - Em R\$ bilhões de dez/2009 (INPC)

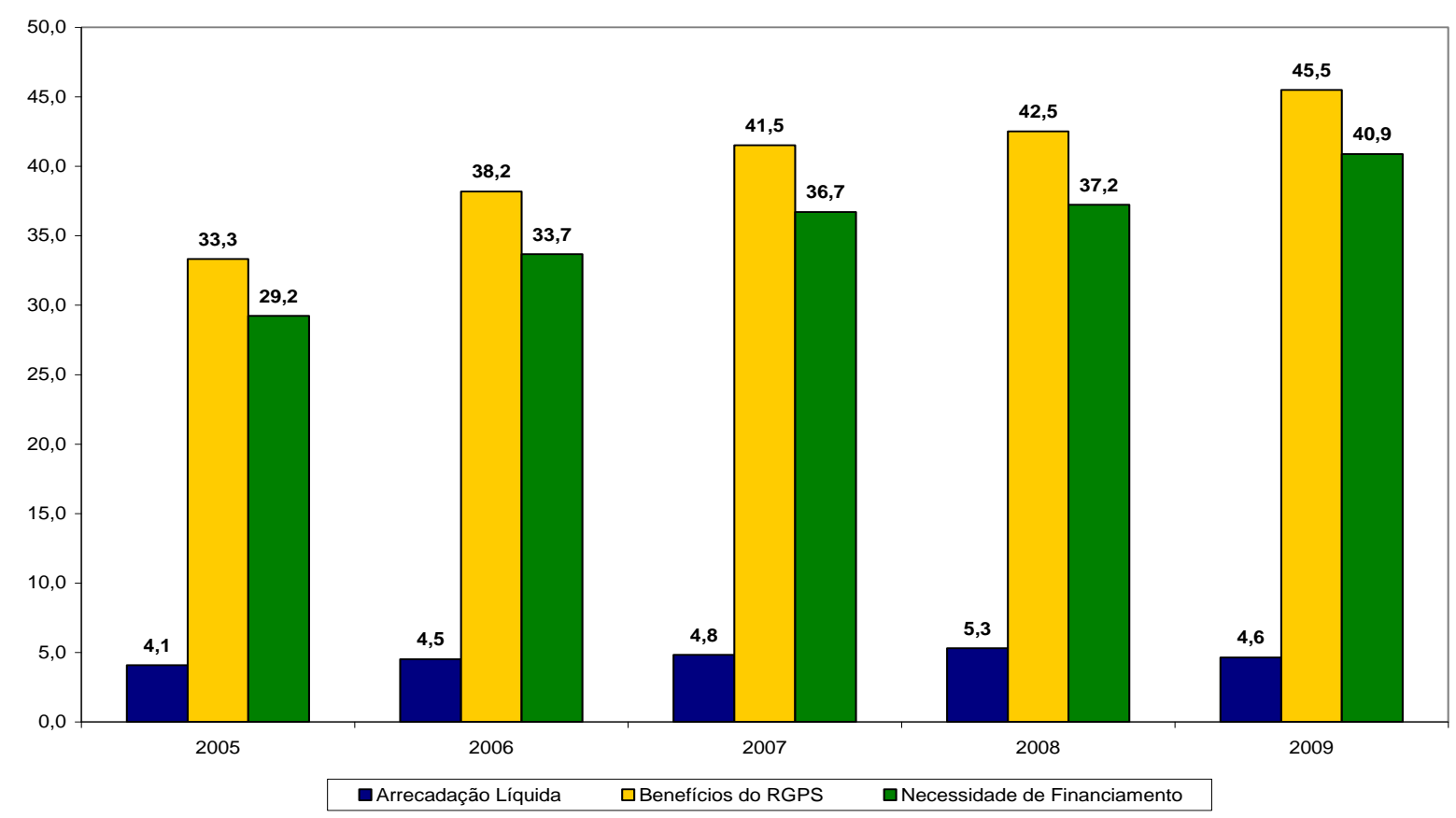

Fonte: Fluxo de Caixa do INSS (ajustado pelo sistema INFORMAR/DATAPREV);

Elaboração: SPS/MPS.

Gráfico 3

Necessidade de Financiamento do RGPS RURAL em \% do PIB - 2005 a 2009

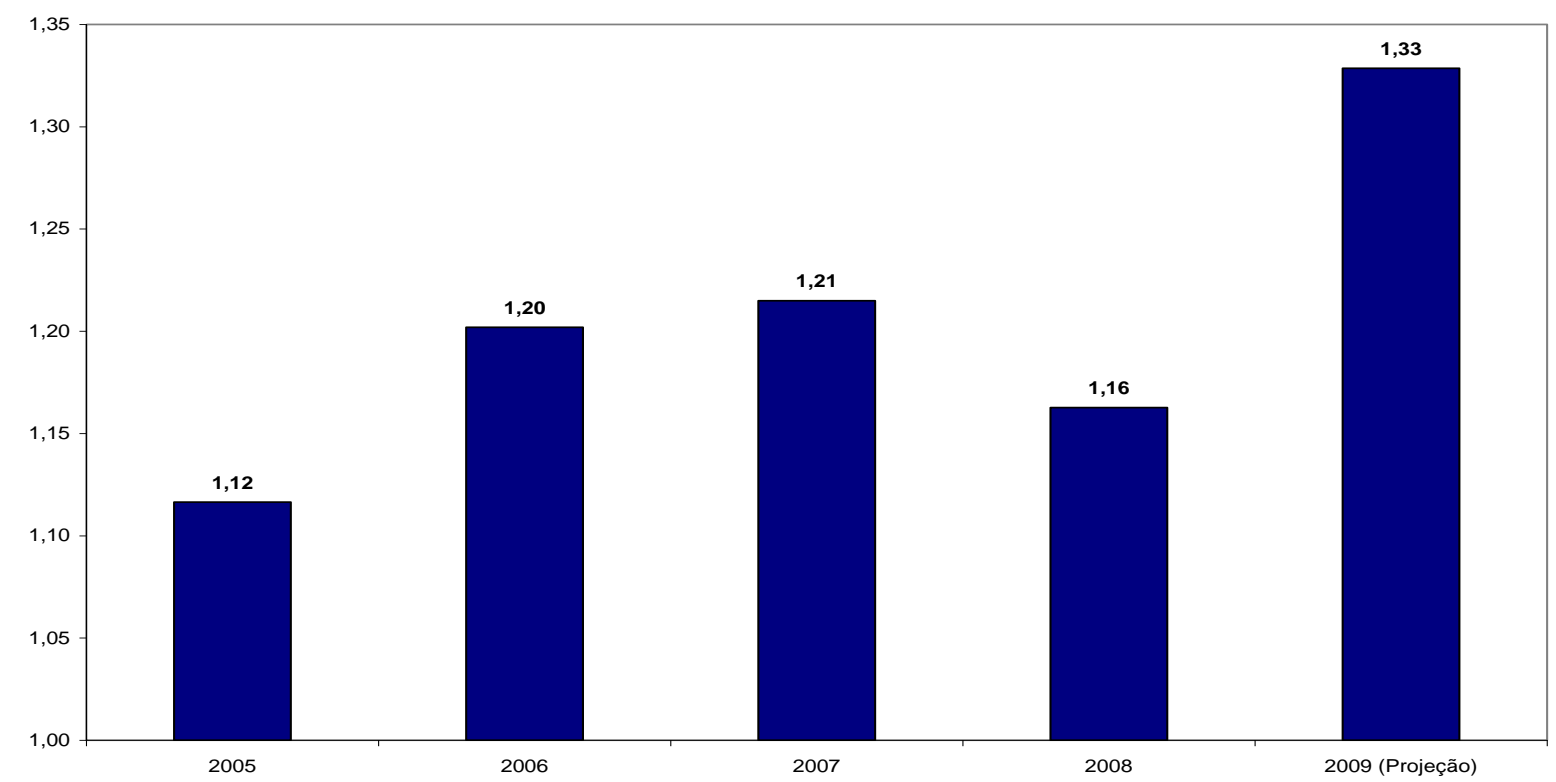

Fontes: Fluxo de Caixa do INSS (ajustado pelo sistema INFORMAR/DATAPREV); IBGE - Contas Nacionais. Elaboração: SPS/MPS. Nota: Em 2009, PIB projetado.

Analisando este quadro de necessidade de financiamento estável, ao redor de $1 \%$ do PIB, apontam-nos Delgado e Castro (2003) que, a considerar as regras de contribuição e 
benefícios atualmente vigentes, a relativa incapacidade de autofinanciamento do subsistema rural de previdência é natural, não tendo este subsistema sido gestado com a perspectiva de auto-suficiência, mas sim de promover proteção social e combate à pobreza entre idosos, inválidos e viúvos(as), o que, afirmam os autores com base em estudos técnicos, estes objetivos têm sido atingidos.

Assim, defendem os autores (ob. cit, p. 15) que a necessidade de financiamento da previdência rural justifica-se pelo bem social que esta política inclusiva resulta, devendo, assim, ser custeada de forma solidária por toda a sociedade por meio de transferências tributárias, verbis:

\begin{abstract}
Sendo assim, o valor dos benefícios pagos na Previdência Rural caracteriza-se para todos os efeitos como um bem social (ou um bem público) para cujo acesso não é lícito, em geral, que seja requerido pagamento dos seus usufrutuários - agricultores familiares em excedentes -, haja vista serem estes, em sua grande maioria, agricultores pobres, com baixos excedentes ou simplesmente produtores do setor de subsistência.

(...) Portanto, esse gasto caracteriza-se como a contrapartida financeira de um direito social, que deve ser assumido pelo conjunto da sociedade e financiado sob a forma de uma transferência tributária. Não deve, do ponto de vista de eqüidade fiscal, ser assumido pelos contribuintes urbanos, como tem sido a regra implícita na execução orçamentária do Tesouro Nacional em sua relação com o INSS. A responsabilidade dessa suplementação deve ser assumida pelas fontes tributárias ou quase-tributárias, que caracterizam várias das contribuições sociais integrantes do Orçamento da Seguridade Social e que se destinam precisamente a essa finalidade.
\end{abstract}

Por outro lado, ressalta Delgado (1999) que, embora o "déficit" seja estrutural, pode ser minimizado se for imposta maior eficiência na máquina arrecadatória, principalmente sobre as contribuições incidentes sobre a comercialização agropecuária que ainda revelam alto grau de evasão fiscal.

Segundo o autor, a mudança viável na contribuição dos segurados especiais, provavelmente seria a de instituí-la como contribuição simbólica geral, sem pretensão de se alcançar equilíbrio orçamentário por esta via, pois o financiamento do déficit estrutural deve estar explicitamente remetido às contribuições parafiscais específicas do "Orçamento da Seguridade", que se destinam a suprir deficiências do sistema previdenciário e financiar programas sociais explícitos de combate a pobreza. 
Concordamos com a ANFIP (2007) quando afirma que a incapacidade da contribuição sobre a produção rural financiar os benefícios decorrentes das relações de trabalho no campo não resulta simplesmente de uma suposta benevolência do Constituinte de 1988, que inovou ao reconhecer os direitos do trabalhador rural.

Entre os fatores destacados pela ANFIP (2007) para justificar o desequilíbrio nas contas da previdência rural, estão

(a) Que menos de $20 \%$ dos trabalhadores ativos estão relacionados com o trabalho rural. Em 1970, esse percentual superava 44\%. A quase totalidade das despesas com benefícios rurais refere-se ao grupo de trabalhadores aposentados ou em vias de se aposentar. Essas despesas não conseguem ser financiadas pela comercialização da produção desse setor econômico, que hoje representa menos de $10 \%$ da economia nacional.

(b) A grande desigualdade econômica existente no campo e a desproporção entre a capacidade econômica dos diversos segmentos e sua respectiva participação tributária.

(c) Embora, em tese, o critério da contribuição pelo resultado da comercialização seja universal para as relações no campo, há uma imunidade para o setor exportador. Por força de dispositivo constitucional, esse setor deixou de pagar contribuições sociais que incidem sobre o seu faturamento, dentre elas as contribuições previdenciárias. Assim, foi construído o seguinte cenário: como os setores com maior capacidade econômica ficaram dispensados de contribuir, não se pode exigir que a comercialização da produção dos assentamentos, das pequenas propriedades e das unidades produtivas familiares, seja suficiente para arcar com as despesas que são relativas a outro momento econômico, representativo de uma quantidade muito mais expressiva de trabalhadores.

(d) Para complicar ainda mais a questão, a forma da contribuição rural (incidência sobre a comercialização) se dá sobre um conjunto de transações de natureza muito pulverizada, tornando difícil o controle e facilitando a sonegação. Também não se pode ignorar que uma elevação das alíquotas contributivas sobre a comercialização da produção agropecuária, que se destina ao mercado interno (já que as exportações estão imunes), terá grande repercussão, por exemplo, no preço dos alimentos. Estaríamos, assim, agindo na direção oposta da desoneração dos gêneros da cesta básica. 
Por todas essas questões, concluí a $\operatorname{ANFIP~(2007,~p.~55)~que~desqualificar~o~segurado~}$ rural, quer seja classificando seu benefício como assistencial, quer seja responsabilizando-o direta ou indiretamente pelo chamado déficit previdenciário, é uma grande afronta social e uma inconcebível maquiagem sobre a realidade dos fatos.

\begin{abstract}
Ao contrário de construir essas críticas sobre a estruturação da previdência no âmbito rural, deve-se compreender que foi essa estrutura a responsável pela ampliação, quase universal, do direito previdenciário no campo. Sob essa ótica, a previdência rural brasileira não apresenta uma movimentação contrária à tendência internacional, uma vez que as pessoas que não podem contribuir para sua aposentadoria são financiadas pelo Estado por meio de tributos gerais e não através de contribuições. Neste sentido, devido ao baixo grau de financiamento das atividades produtivas rurais, mediante a predominância da agricultura de subsistência, é impraticável que a previdência rural seja financiada por contribuições individuais. Ao contrário, o sistema de segurado especial deveria servir de exemplo para os setores informais urbanos, que em virtude do alto número de trabalhadores no setor informal, deveria ser financiado por meio de tributos gerais. Estaríamos assim dando um passo importante no combate à pobreza e na introdução da Lei $\mathrm{n}^{\circ}$. 10.835, de 08 de janeiro de 2004, que institui a Renda Básica de Cidadania para todos os brasileiros.
\end{abstract}

De fato, a necessidade de forte financiamento da previdência rural não deslegitima esta espécie de política de proteção social porque parte deste "déficit" decorre de renúncias fiscais franqueadas pela legislação, notadamente, a imunidade quanto à incidência de contribuições sociais, conferida pela Emenda Constitucional n. ${ }^{\circ} 33$, de 2001, sobre as receitas decorrentes de exportação, o que, embora incremente a competitividade do mercado exportador brasileiro, exclui significativa parcela da arrecadação resultante da atividade rural.

Tem-se, ainda, que a análise comparada de países que adotaram alguma política de previdência na área rural, o que será visto com mais vagar no item seguinte, revela que em todos eles há necessidade de financiamento público, dadas as características de baixa formalização e de não assalariamento do labor no campo.

\title{
3. Impacto Social da Previdência Social Rural
}

Em contrapartida aos aspectos de custeio do sistema previdenciário rural, apontados por alguns como grande vilão das contas públicas em face da decantada relação 
desproporcional entre a correspectiva arrecadação e o pagamento de benefícios, tem-se o positivo impacto social decorrente da universalização deste sistema.

A maioria dos trabalhos que defendem o papel social da previdência rural na feição que lhe deu a Magna Carta de 1988 afirmam que esta é um dos mais poderosos mecanismos de redistribuição de renda, atuando no sentido de transferir riqueza dos estados e municípios mais ricos para os mais pobres, na fixação do seu público alvo nos seus municípios de origem, de financiar a política agrícola familiar e na diminuição dos índices de miséria e de pobreza da população rural.

Delgado e Cardoso (1999, p. 21-22) em pesquisa de campo realizada no segundo semestre de 1998, junto a 6 mil domicílios das regiões Sul e Nordeste do Brasil, destinada a avaliar os impactos socioeconômicos e regionais da Previdência Social Rural, concluíram que, em termos macrossociais, a implantação da previdência no meio rural trouxe resultados significativos, que podem se traduzir em indicadores de impacto, tais como:

a) aumento expressivo da taxa de cobertura dos idosos rurais, medida pela população beneficiária sobre a população total de idosos potencialmente credora de direitos à aposentadoria. Essa taxa, que chega a 93\% na amostra de domicílios cadastrados como "zona rural" pelo INSS, é seguramente mais baixa na "zona rural tradicional", mas é certamente mais alta que no "regime geral" (urbano) da Previdência Social;

b) inclusão expressiva das mulheres rurais no sistema de proteção social, mais que compensando a relativa exclusão anterior do Funrural. Hoje (1998), constata-se, na pesquisa domiciliar das regiões Sul e Nordeste, que cerca de 63,2\% dos aposentados e pensionistas do Sul e 62,2\% do Nordeste são mulheres; e

c) elevação significativa da renda domiciliar do público beneficiário, incidindo tais benefícios sobre uma população rural ou microurbana, em geral, muito pobre.

Schwarzer (2000a, p. 17) chama atenção, ainda, para o fato de que o subsistema previdenciário rural ser deficitário não é, em si, grave, pois o mesmo apresenta uma série de externalidades positivas que o justificam.

No entanto, por si, o fato de o subsistema ser deficitário não é grave, como poderia parecer inicialmente. Primeiro, viu-se que não há, na experiência internacional, conhecimento de nenhum caso de sistemas de aposentadorias voltado ao setor agropecuário que não seja deficitário. Segundo, projeções apontam para uma estabilização e mesmo diminuição do déficit do subsistema no futuro [Delgado (1997)], uma vez que o salto quantitativo do número de benefícios foi concluído em 1994 e é de conhecimento geral que há uma tendência à redução da população ocupada na agropecuária nas décadas vindouras. Terceiro, há uma estimativa de evasão de contribuição no setor rural muito elevada: Delgado (1997) estima que a contribuição sobre a produção agropecuária tenha sido de apenas $22 \%$ da 
arrecadação potencial em 1995, enquanto dos contribuintes individuais obrigatórios, em uma estimativa já mais defasada, apenas 7,6\% efetivamente estavam aportando à previdência no setor rural em 1989 [Kageyama e Silva (1993)]. Quarto, o subsistema previdenciário rural apresenta uma série de externalidades positivas, que parecem ir muito além da proteção específica aos segurados rurais e beneficiam a sociedade brasileira em geral, em relação às quais serão traçadas algumas pistas nos trechos a seguir. A presença de externalidades positivas, na teoria econômica dos bens públicos, é justificativa para a instituição de um subsídio à respectiva atividade/programa, o que otimiza o bem-estar de toda a coletividade e não apenas o dos beneficiários diretos do objeto de suplementação orçamentária. No transcurso da discussão da reforma previdenciária no Brasil, portanto, esses seriam aspectos a contemplar em uma avaliação mais ponderada do subsistema rural da Previdência Social, a fim de evitar julgamentos baseados apenas em raciocínios contábeis.

As atuais regras do subsistema previdenciário rural incrementaram a inclusão previdenciária, a permitir que, no ano de 2009, a Previdência Social pagasse, em média, 23,5 milhões de benefícios previdenciários (rurais e urbanos) mensais, com valor acumulado em torno de $\mathrm{R} \$ 220$ bilhões e com presença em todo território nacional. De acordo com dados do PNAD 2008, 65,91\% da população ocupada no Brasil (entre 16 e 59 anos), está coberta por algum regime público de previdência.

\section{Gráfico 4}

Evolução da Cobertura Social entre as Pessoas com Idade entre 16 e 59 anos 1992 a 2008

(Exclusive Área Rural da Região Norte, salvo Tocantins)

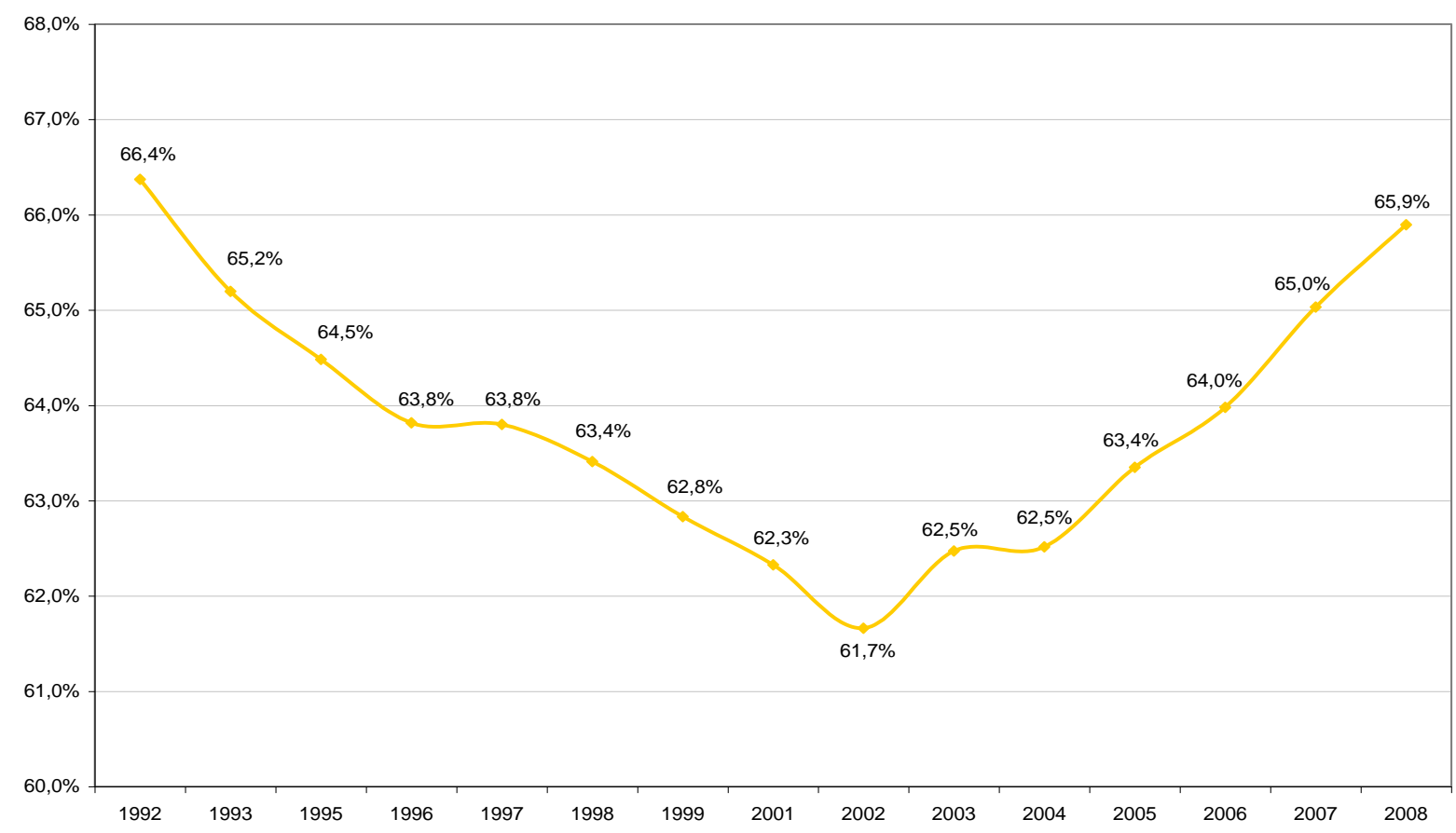

Fonte: PNAD - vários anos. Elaboração: MPS (2009, p. 01). 
Como pode ser observado pelo Gráfico 4, os cidadãos brasileiros cobertos pela previdência social, em 2008, representavam quase 66\% da PEA, ou 55,36 milhões de pessoas, o que revela a continuidade da expansão desta cobertura observada desde 2002. Segundo o MPS (2009a), mais uma vez, o responsável por tal crescimento foi o resultado positivo dos empregos com carteira assinada, cujo alcance passou de $30 \%$ para $35,7 \%$ da PEA, ou de 22,2 para 33,4 milhões de pessoas entre os anos de 2001 e 2008. Merece destaque também a queda do percentual de desocupados, que em 2008 apresentou o menor valor da década. Observa-se ainda a lenta, mas persistente, queda do percentual de trabalhadores que não contribuem para a previdência social, em suas diversas modalidades contributivas. Em números absolutos, os informais representavam em 2008 31,1 milhões de pessoas.

Apesar da ascendência da curva de cobertura previdenciária, ainda é preciso avançar muito, sobremaneira, no que diz respeito à população jovem, pois, de acordo com dados do PNAD (2008), 34,1\% da PEA (ou 28,61 milhões de pessoas entre 16 e 59 anos de idade) ainda não está coberta por qualquer regime de previdência pública, segundo comparativo internacional de Previdência Social promovido por Caetano e Rocha (2008), o sistema previdenciário brasileiro mesmo assim consegue propiciar um dos mais altos níveis de cobertura na América Latina, conforme ilustra o gráfico abaixo.

\section{Gráfico 5}

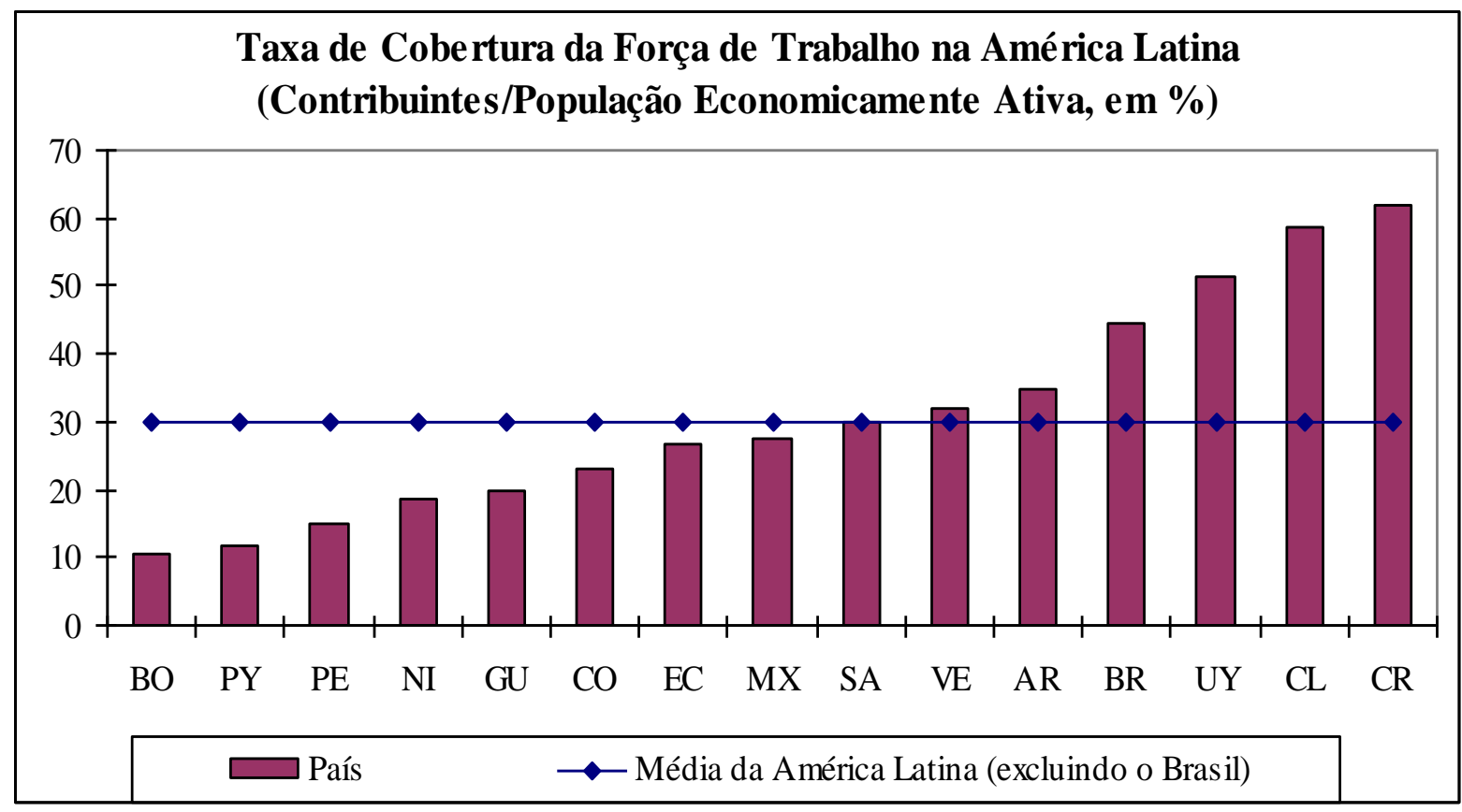

Fonte: Caetano e Rocha, 2008, p. 16. 
A cobertura previdenciária da população brasileira é mais expressiva quando se trata de pessoas idosas (com 60 anos ou mais de idade), independentemente de critério de renda, que recebem aposentadoria e/ou pensão ou que continuam contribuindo para algum regime previdenciário. Nesse segmento, mostra o Gráfico 6, a percentagem média de cobertura previdenciária cresceu 74,03\% em 1992 para 81,79\% em 2008.

\section{Gráfico 6}

BRASIL: Idosos de 60 anos ou mais que recebem aposentadoria e/ou pensão ou que continuam contribuindo para algum regime - 1992 a 2008 (em \%) -

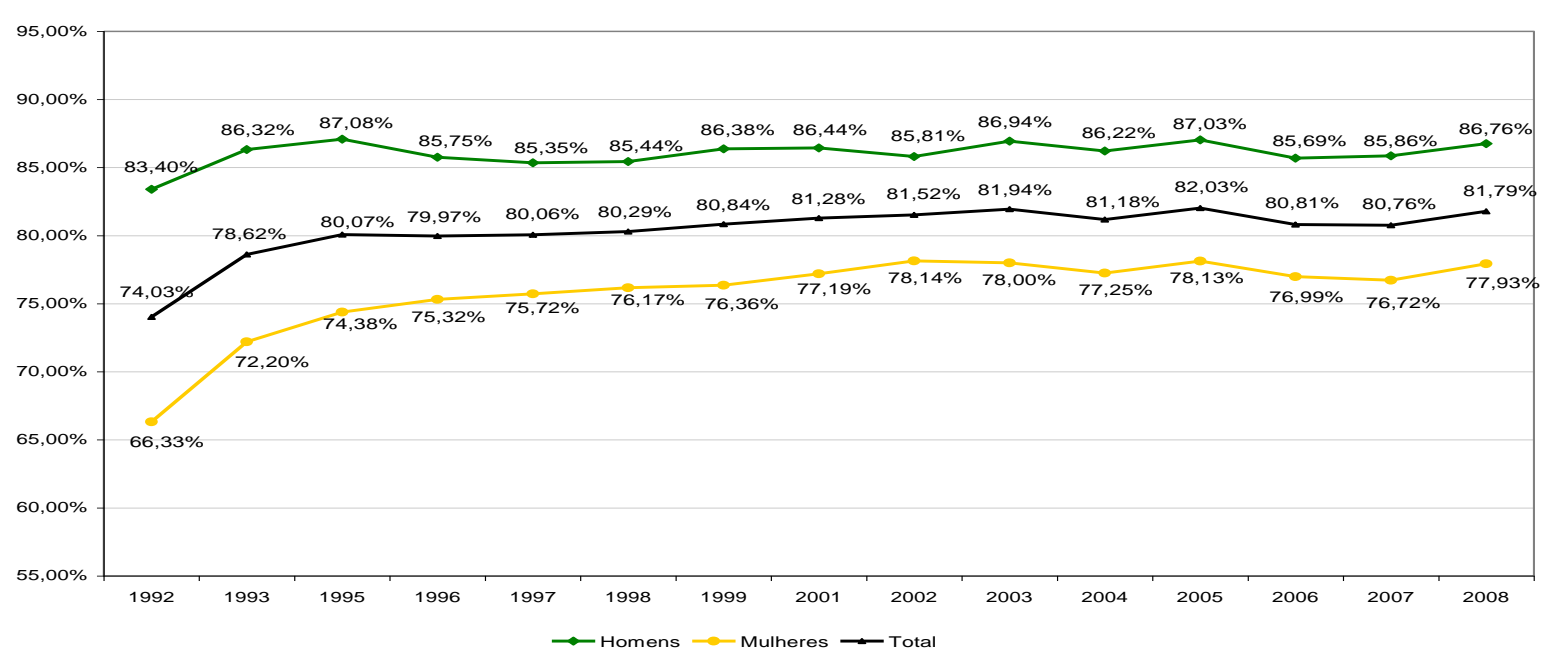

Fonte: PNAD/IBGE - Vários anos. Elaboração: SPS/MPS.

Como apuram Caetano e Rocha (2008) é a maior cobertura previdenciária da população idosa entre os países da América Latina.

\section{Gráfico 7}

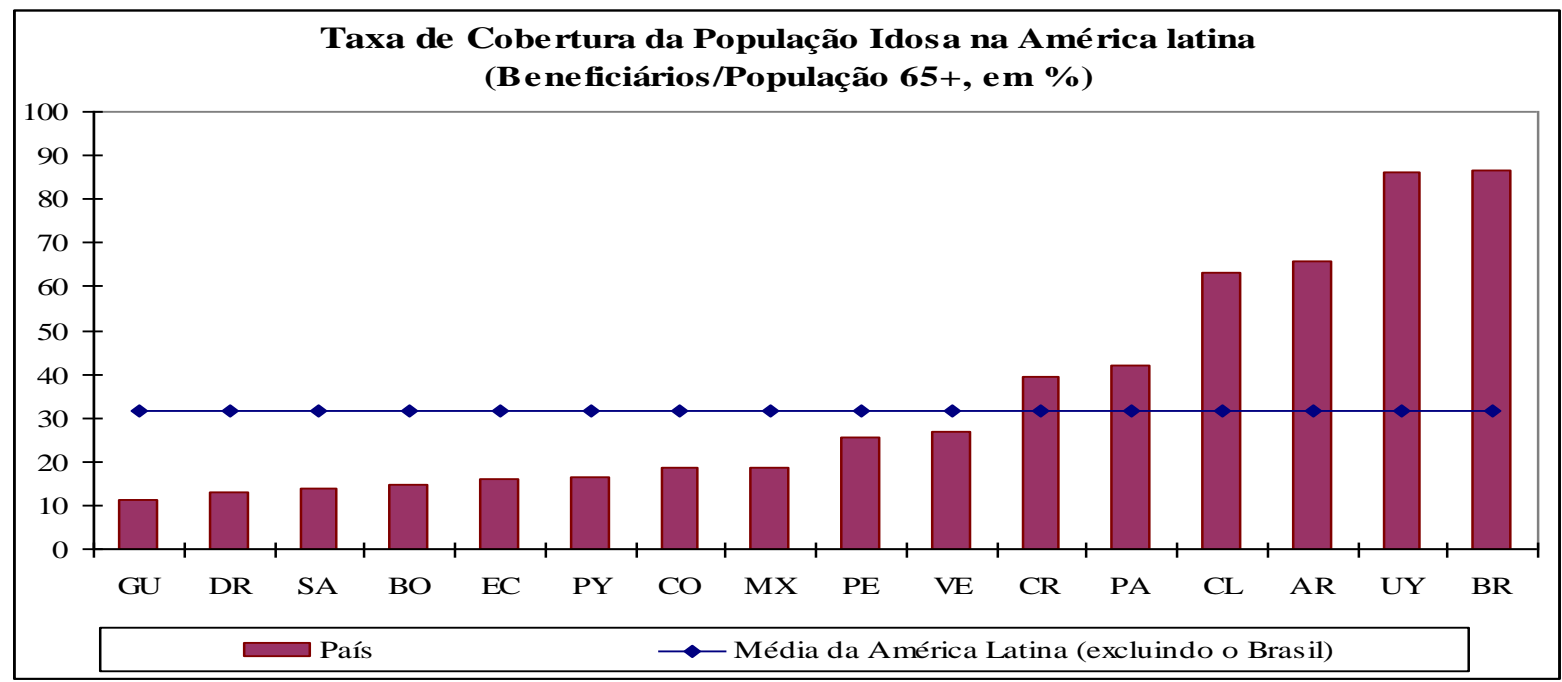

Fonte: Caetano e Rocha, 2008, p. 16. 
A Tabela 1 revela que se fossem retirados todos os benefícios previdenciários atualmente pagos pela Previdência Social, a população de indigentes ou em pobreza extrema (pessoas que vivem com renda domiciliar per capita inferior a um quarto de salário mínimo) cresceria, no ano de 2008, em mais de 17 milhões de indivíduos; e o de pobres ou em pobreza absoluta (pessoas que vivem com renda domiciliar per capita inferior a meio salário mínimo), em quase 21 milhões. O percentual de indigentes praticamente dobraria, passando de 10,74\% para 20,19\% da população, enquanto o percentual de pobres subiria em mais de um terço, passando de 29,18\% para 40,56\%. Esses números apontam a importância da proteção previdenciária no combate à indigência e à pobreza no Brasil.

\section{Tabela 1}

Pobreza e indigência sem e com benefícios previdenciários (Brasil) - 2001 a 2008

\begin{tabular}{|c|c|c|c|c|c|c|c|c|}
\hline \multirow{2}{*}{$\begin{array}{c}\text { Pobreza e } \\
\text { indigência sem } \\
\text { e com } \\
\text { benefícios } \\
\text { previdenciários } \\
\text { Ano }\end{array}$} & \multicolumn{4}{|c|}{ Indigentes } & \multicolumn{4}{|c|}{ Pobres } \\
\hline & $\begin{array}{c}\text { sem } \\
\text { benefício }\end{array}$ & $\begin{array}{c}\text { com } \\
\text { benefício }\end{array}$ & $\begin{array}{c}\text { queda } \\
\text { em } \\
\text { p.p }\end{array}$ & População & $\begin{array}{c}\text { sem } \\
\text { benefício }\end{array}$ & $\begin{array}{c}\text { com } \\
\text { benefício }\end{array}$ & $\begin{array}{c}\text { queda } \\
\text { em } \\
\text { p.p }\end{array}$ & População \\
\hline 2001 & 14,33 & 6,35 & 7,98 & 13.326 .398 & 26,79 & 17,17 & 9,62 & 16.069 .726 \\
\hline 2002 & 14,29 & 6,08 & 8,21 & 13.954 .552 & 28,07 & 18,08 & 9,99 & 16.967 .463 \\
\hline 2003 & 18,25 & 8,94 & 9,31 & 16.030 .990 & 35,63 & 24,69 & 10,94 & 18.831 .870 \\
\hline 2004 & 17,69 & 9,01 & 8,68 & 15.394 .911 & 35,76 & 25,15 & 10,61 & 18.807 .839 \\
\hline 2005 & 18,53 & 9,66 & 8,87 & 16.016 .375 & 37,69 & 27,07 & 10,62 & 19.193 .468 \\
\hline 2006 & 19,30 & 10,21 & 9,09 & 16.556 .207 & 39,22 & 28,21 & 11,02 & 20.053 .148 \\
\hline 2007 & 20,45 & 11,02 & 9,44 & 17.263 .345 & 40,59 & 29,33 & 11,26 & 20.597 .703 \\
\hline 2008 & 20,19 & 10,74 & 9,45 & 17.394.259 & 40,56 & 29,18 & 11,38 & 20.948 .836 \\
\hline
\end{tabular}

Fonte: microdados das PNADs. Elaboração: IPEA (2009a), p. 28.

A evolução destes indicadores de proteção social, mormente, entre os idosos, deve-se significativamente à instituição da categoria de segurado especial, determinada pela CF de 1988, e regulamentada em 1991, que possibilitou a expansão da cobertura previdenciária no meio rural. Sem desconsiderar que o comportamento positivo dos índices de proteção social pode estar relacionado também ao aumento do número de beneficiários da Lei Orgânica da Assistência Social - LOAS, mormente, a partir do advento do Estatuto do Idoso, vigente 
desde janeiro de 2004, que facilitou os requisitos necessários para a concessão deste benefício assistencial de prestação continuada.

\section{Previdência Rural no Contexto Internacional de acordo com a tipologia de Helmut Schwarzer}

A fim de que possamos situar melhor a experiência brasileira no processo de expansão e cobertura da Previdência Social ao trabalhador rural, é fundamental conhecer um pouco da experiência internacional nessa temática. Nossa referência para atingir esse objetivo será pautada na original pesquisa de Schwarzer (2000b), que construiu uma tipologia ${ }^{17}$ de sistemas previdenciários rurais, composto de quatro grupos, abaixo minudenciados, aos quais ele denomina de quatro paradigmas, desenvolvidos em estudos de caso sobre vinte e dois países citados como exemplo de cada um dos modelos.

\section{Quadro 2}

Tipologia de Modelos de Cobertura Previdenciária Rural

\begin{tabular}{|c|c|c|}
\hline & CONTRIBUTIVO & NÃO CONTRIBUTIVO \\
\hline Mais desmercantilizante & $\begin{array}{c}\text { Modelo contributivo diferenciado } \\
\text { Ex.: Alemanha }\end{array}$ & $\begin{array}{c}\text { Modelo universal básico } \\
\text { Ex.: Finlândia, Canadá }\end{array}$ \\
& & \\
\hline Menos desmercantilizante & Modelo contributivo estrito & Modelo assistencial \\
& Ex.: EUA & Ehile, Costa Rica \\
& & \\
\hline
\end{tabular}

Fonte: Schwarzer, 2000b, p.8.

No Quadro 2, é possível visualizar a relação entre o acesso individual à cobertura da previdência e a maior ou menor dependência do desempenho prévio do indivíduo no mercado, como fator de acesso. Porém, para melhor explicitar o quadro acima, ninguém mais recomendável que seu próprio autor (ibidem, p.8-9):

\footnotetext{
17 Adverte o autor que a classificação de países em uma tipologia não deixa de possuir um componente arbitrário, na medida em que, como há de se notar, nenhum país corresponde completamente ao modelo puro para o qual está sendo citado como exemplo. Uma das características que se destaca na realidade é que, geralmente, há o emprego simultâneo de combinações de instrumentos das diversas matrizes originárias. (2000b, p.9).
} 
Conforme o quadro 1, têm-se, assim, dois modelos de previdência com vínculo contributivo, dos quais o mais rígido (menos desmercantilizante) é o que utiliza uma relação atuarial mais estrita, aplicando à população rural as mesmas regras da população urbana. $\mathrm{O}$ outro modelo contributivo é diferenciado, menos atuarial do que o urbano, e, neste, o segurado rural percebe alguma forma de subsídio, seja do Tesouro nacional, seja de outro regime previdenciário. Têm-se também dois tipos não contributivos, em que o direito de acesso ao sistema passa por critérios outros que não a relação contributiva. $\mathrm{O}$ primeiro, o mais decomodificante, garante uma prestação básica a qualquer cidadão e corresponde ao paradigma beveridgiano originário. O segundo tipo não contributivo estabelece critérios de necessidade para a concessão de benefício e corresponde, de forma geral, ao paradigma assistencialresidual.

Um primeiro grupo é composto por países que utilizam o modelo universal básico, do tipo beveridgiano. Nesse modelo, a população rural é incluída na proteção previdenciária por meio do direito a uma aposentadoria universal básica, resultante de um direito de cidadania abrangente. A Finlândia é um exemplo deste modelo, cuja inspiração universalista original foi submetida a reformas nas últimas décadas, introduzindo elementos clássicos do modelo assistencial e contributivo no sistema. A aposentadoria nacional é concedida a urbanos e rurais com idade de 65 anos, sendo possível com 60 anos, aplicando um redutor e com tempo de residência mínimo de 3 a 5 anos no país. O valor da aposentadoria varia de forma proporcional ao tempo de residência, atingindo o valor pleno (cerca de US\$ 483 mensais, em 1999) com quarenta anos de residência entre os 16 e os 65 anos de idade. Existe também a aposentadoria ocupacional, ligada ao emprego e salário do trabalhador. De acordo com o valor da aposentadoria ocupacional e da renda do cônjuge há redução na aposentadoria nacional, podendo até desaparecer. Dessa forma a aposentadoria nacional exerce a função de garantia de renda mínima na idade avançada.

Um segundo grupo de países é formado por sistemas que, embora baseados nos princípios contributivos bismarckianos, discriminam positivamente a clientela rural no desenho das regras de contribuição e elegibilidade (modelo contributivo diferenciado). Nesse caso, portanto, ou o setor urbano subsidiará o setor rural, ou o Tesouro nacional do país cobre a vantagem atuarial oferecida ao segurado rural. O modelo contributivo diferenciado, no caso da Alemanha, constitui-se num sistema contributivo que possui um regime geral e um regime rural. O regime geral segue a lógica contributiva bismarckiana, compreende os trabalhadores urbanos e os assalariados rurais. Como a remuneração dos rurais é sistematicamente inferior aos valores urbanos, há um caixa de suplementação para esse grupo, financiado por tributos federais. Os agricultores familiares contribuem obrigatoriamente, inclusive o cônjuge e os 
membros não remunerados da família. Entretanto, é possível que os segurados tenham descontos de até $60 \%$ sobre a contribuição mensal, em casos de rendimentos insuficientes. A idade para se aposentar é de 65 anos com 15 anos de contribuição. O valor do benefício é proporcional ao tempo de contribuição. O financiamento do regime rural é deficitário e depende de subvenções do Estado.

No terceiro grupo, o modelo contributivo estrito, as regras de acesso, de contribuição e o leque de benefícios urbanos são transpostos aos grupos ocupacionais rurais de forma indistinta. No modelo contributivo indiferenciado, utilizado nos EUA, as mesmas regras são aplicadas aos trabalhadores assalariados dos setores urbano e rural. Quanto à agricultura familiar, a contribuição é feita tendo por base os rendimentos da atividade agrícola, gerando contribuição individual. O teto dos rendimentos para a incidência da contribuição é de 72.600 US\$/ano. A aposentadoria por idade ocorre aos 65 anos. Autônomos urbanos e rurais também devem contribuir. Se o cidadão não possuir renda ou patrimônio suficientes para garantir um padrão mínimo de sobrevivência é possível requerer uma complementação oferecida pelo Estado. Dessa forma pode-se perceber que o modelo contributivo dos EUA incorpora elementos do modelo assistencial.

Finalmente, o quarto grupo de países oferece alguma forma de cobertura ao setor rural por meio de benefícios assistenciais (modelo assistencial), baseados em critérios de focalização e não em direitos universais básicos ou contributivos. O modelo assistencial, utilizado no Chile, é um sistema de previdência compulsória com capitalização plena e administrado por entes privados (Administradoras de Fundos de Pensão - AFP). Cada contribuinte acumula contribuições obrigatórias em uma conta pessoal, criando uma poupança, a partir da qual serão pagos benefícios ao final da vida ativa. $O$ setor rural não tem sido atrativo para as AFP. A cobertura é feita pelas aposentadorias assistenciais (pensiones asistenciales). Os beneficiários devem ter idade de 65 anos e renda domiciliar per capita inferior à metade da aposentadoria mínima garantida no regime AFP. O financiamento é do tesouro nacional. O valor real dos benefícios era de cerca de US\$ 50 mensais em 1998. Dessa forma, o acesso ao benefício se dá a partir da comprovação de um critério de necessidade.

Em seguida, Schwarzer (2000b) sintetiza sua tipologia noutro Quadro 3, igualmente didático e elucidativo, esclarecendo que os estudos de caso referem-se, centralmente, à aposentadoria por idade. 


\section{Quadro 3}

Resumo das Principais Características e Tendências dos Modelos de Cobertura Previdenciária Rural

\begin{tabular}{|c|c|c|c|c|}
\hline & $\begin{array}{l}\text { Modelo universal } \\
\text { básico }\end{array}$ & $\begin{array}{c}\text { Modelo } \\
\text { contributivo } \\
\text { diferenciado }\end{array}$ & $\begin{array}{c}\text { Modelo } \\
\text { contributivo } \\
\text { estrito }\end{array}$ & $\begin{array}{c}\text { Modelo } \\
\text { assistencial }\end{array}$ \\
\hline $\begin{array}{c}\text { Característica } \\
\text { Principal }\end{array}$ & $\begin{array}{c}\text { Benefício básico } \\
\text { universal, } \\
\text { independentemente de } \\
\text { contribuição }\end{array}$ & $\begin{array}{c}\text { Diferencia regras } \\
\text { entre regimes urbano } \\
\text { e rural }\end{array}$ & $\begin{array}{l}\text { Não diferencia } \\
\text { entre regimes } \\
\text { urbano e rural }\end{array}$ & $\begin{array}{c}\text { Cobre com } \\
\text { benefícios tipo } \\
\text { assistenciais }\end{array}$ \\
\hline $\begin{array}{c}\text { Elemento } \\
\text { previdenciário }\end{array}$ & $\begin{array}{c}\text { Suplementado por } \\
\text { previdência } \\
\text { contributiva pública ou } \\
\text { privada }\end{array}$ & $\begin{array}{c}\text { Previdência } \\
\text { contributiva sem } \\
\text { equilíbrio atuarial } \\
\text { individual e coletivo }\end{array}$ & $\begin{array}{l}\text { Previdência } \\
\text { contributiva com } \\
\text { maior rigor } \\
\text { atuarial }\end{array}$ & $\begin{array}{l}\text { Ou previdência } \\
\text { contributiva } \\
\text { inacessível, ou não } \\
\text { compulsória }\end{array}$ \\
\hline $\begin{array}{c}\text { Tendências de } \\
\text { reforma }\end{array}$ & $\begin{array}{l}\text { Reforço de elementos } \\
\text { assistenciais e } \\
\text { contributivos }\end{array}$ & $\begin{array}{l}\text { Diminuição da } \\
\text { diferença rural- } \\
\text { urbano }\end{array}$ & $\begin{array}{c}\text { Ajuste de } \\
\text { parâmetros gerais } \\
\text { (alíquota, idade) }\end{array}$ & $\begin{array}{c}\text { Focalização mais } \\
\text { precisa }\end{array}$ \\
\hline Exemplos & $\begin{array}{c}\text { Finlândia, Suécia, } \\
\text { Canadá }\end{array}$ & $\begin{array}{l}\text { Alemanha, Áustria, } \\
\text { França, Polônia }\end{array}$ & $\begin{array}{l}\text { EUA, Itália } \\
\text { (novo) }\end{array}$ & $\begin{array}{c}\text { Chile, Costa Rica, } \\
\text { outros países } \\
\text { latino-americanos }\end{array}$ \\
\hline
\end{tabular}

Fonte: Schwarzer, 2000b, p. 36.

Não obstante, pontua o autor que alguns elementos permanecem comuns à previdência rural nos mais diversos países do mundo. São eles:

a) o setor rural, no que concerne à pequena agricultura de base familiar, apresenta rendimentos domiciliares médios inferiores aos urbanos. Esse fenômeno também se traduz no fato de que, normalmente, os benefícios destinados ao setor rural são mais modestos quando há regime diferenciado, ou o valor médio dos benefícios obtidos em regimes indiferenciados é bastante inferior ao padrão urbano;

b) o setor rural está sujeito a processos de transformação estrutural profundos e a tendência geral é de queda da população ocupada na agricultura. Assim, pode-se concluir que iniciativas que procurem uma estrutura de financiamento baseada na capacidade contributiva rural estão destinadas, desde já, a fracassar, uma vez que a base potencial de arrecadação na 
área rural é reduzida e a relação contribuintes/beneficiários tenderá a deteriorar-se continuamente.

c) a proteção social ao setor rural dificilmente pode prescindir de transferências de recursos advindas de outros setores, seja via Tesouro, seja via transferências entre diferentes regimes previdenciários. Os Welfare State comprometidos com maior homogeneidade urbano-rural subsidiam marcadamente os sistemas de proteção social para a área rural.

Sobre este último aspecto, o autor aponta uma tendência internacional de estreitar o vínculo contribuição/benefício na previdência rural, mas por outro lado reafirma a necessidade da manutenção de elementos redistributivos, que podem ser articulados: "Seja internamente ao regime (transferências urbano-rurais ou injeção de recursos do Tesouro), seja externamente, via assistência social e outros programas complementares ou mesmo via orçamento de política agrária da UE, continuará presente para os regimes previdenciários rurais". (2000, p. 38)

Sobre o caso brasileiro, Schwarzer (2000b, p.37-39) afirma que a previdência rural brasileira surpreendeu com uma movimentação contrária à tendência internacional e praticamente universalizou a cobertura no setor nos anos 90, salienta que apesar dessa universalização, o regime brasileiro não é assistencial residual, uma vez que o direito de acesso ao benefício não se dá por teste de necessidade, mas pela circunstância de o segurado ter trabalhado na agricultura. E entende que este é um evento mais próximo do conceito de cidadania por residência, adotado nos casos de modelo universal básico para concluir que parece equivocada, a afirmação de que a previdência rural brasileira seja assistencial.

Arremata, assim, o autor:

(...) Dessa forma, o Brasil apresenta um desenho muito peculiar em relação à experiência internacional, uma vez que seu regime previdenciário urbano é contributivo e, na área rural, o país aproxima-se, de fato, de uma aposentadoria básica universal não contributiva: o benefício é de valor único (flat-rate de um salário-mínimo) e não apresenta correlação com rendimentos da fase ativa ou com a base de incidência da contribuição. (2000, p. 38) 
E por fim, conclui que a crescente relevância dos benefícios rurais para o orçamento das famílias dos idosos, deverá transformar, de fato, o programa previdenciário em um programa de garantia de renda mínima para a área rural. 


\section{CAPÍTULO IV}

\section{A RELEVÂNCIA DA PREVIDÊNCIA RURAL NA ECONOMIA DOS MUNICÍPIOS DO RN}

O volume de recursos mensalmente pagos pelo Regime Geral de Previdência Social é expressivo e representa, principalmente para aqueles de menor receita pobres, considerável parcela do Produto Interno Bruto (PIB) dos municípios brasileiros.

Diante deste quadro, alguns estudos têm enfatizado o impacto da Previdência Social sobre a economia de pequenos municípios, onde a dinâmica tem forte vínculo com as transferências de renda previdenciária, ao ponto da existência ou não de agência bancária para pagamento de benefícios previdenciários ser fator determinante do volume de negócios em determinadas localidades.

Nesse sentido, descreveu Schwarzer (2000a, p. 55) em pesquisa de campo realizada no Estado do Pará:

\footnotetext{
Foram colhidas, ao longo das entrevistas realizadas no Pará, declarações que sublinham o papel dinâmico das aposentadorias rurais para muitas economias municipais. Indicativo disso é a tentativa de prefeitos de cidades do interior do Pará de concentrar nas agências bancárias de sua cidade o pagamento de benefícios da região, o que tem como efeito um imediato aquecimento de vendas no comércio do município. O contrário ocorre com os municípios e distritos municipais, nos quais não há pagamento de benefícios ou em que o pagamento de benefícios foi transferido para outra localidade. Isso se dá porque os aposentados normalmente realizam, junto com o saque mensal da aposentadoria, a sua compra mensal de mantimentos e equipamentos, evitando novos deslocamentos para a cidade. Reportou-se, em uma das entrevistas, o exemplo de uma cidade do sul do Pará, em que as agências bancárias fecharam devido ao excesso de assaltos, a agência dos Correios também não poderia garantir a segurança do pagamento mensal de aposentadorias e, em consequiência, os trâmites bancários foram transferidos para outro município. Imediatamente o comércio local sofreu um severo impacto no seu faturamento, o que fez a associação de lojistas local realizar um esforço conjunto para garantir o retorno do pagamento de benefícios previdenciários ao município. Da mesma forma, foi relatado o caso de um distrito do município de Cametá, onde o encerramento de atividades da agência bancária causou profundos prejuízos ao comércio local. Reclamações similares foram ouvidas no município de Salinópolis, na região do Salgado paraense, no qual a única agência bancária havia fechado no início de 1998.
} 
Revisando a literatura, verificou-se, no entanto, a existência de poucas análises sobre a relevância da verba previdenciária, especialmente, a paga à clientela rural, na economia dos municípios do Rio Grande do Norte ${ }^{18}$.

A fim de conhecer o quão expressivo é esse volume de recursos oriundos da Previdência Social para os municípios do RN, o presente capítulo estabelece a comparação do valor destes benefícios previdenciários com as fontes de recursos fiscais igualmente importantes para a composição do orçamento municipal. Além das receitas tributárias próprias, serão objeto de análise comparativa com o valor dos benefícios previdenciários emitidos no RN, a transferência estadual referentes a cota parte do município sobre o ICMS e a transferência federal relativa ao FPM, pois juntos estes três componentes da receita corrente equivalem a aproximadamente 58,7\% do orçamento total dos municípios (Multicidades, 2008).

Com o objetivo de avaliar as questões discutidas acima, o capítulo está organizado da seguinte forma: a) inicialmente, expõem-se características do federalismo no Brasil e a composição da receita dos seus municípios; b) em seguida, são descritas três pesquisas sobre o efeito redistributivo da Previdência Social na economia dos municípios; c) por último são analisadas e cruzadas informações socioeconômicas e os números da Previdência Social no Rio Grande do Norte, com ênfase no subsistema de previdência rural, com intuito de dimensionar a importância desta política pública na economia dos seus municípios.

\section{Breve apresentação das características do federalismo Brasileiro}

Por forma de Estado entende-se a maneira pela qual o Estado organiza o povo e o território e estrutura o seu poder relativamente a outros poderes de igual natureza, que a ele ficarão coordenados e subordinados.

\footnotetext{
${ }^{18}$ Na pesquisa identificamos um estudo de autoria de Joacir Rufino de Aquino e Ronie Cléber de Souza, intitulado "Impactos Socioeconômicos da Previdência Rural no Brasil: um estudo de caso no município de Encanto/RN", no qual os autores analisam os impactos das transferências de renda da Previdência Rural sobre as condições de vida das famílias de aposentados e pensionistas rurais do município de Encanto/RN. Disponível em http://www.sober.org.br/palestra/6/663.pdf. Acesso em 04/06/2010.
} 
Desde a Constituição de 1891, depois de ter sido provisoriamente estabelecida pelo Decreto n. 1, de 1889, o Brasil adota o federalismo como forma de Estado. A federação descentralizada de 1891 recua no grau de descentralização em 1934 e 1946, sendo que, na Constituição de inspiração social-fascista de 1937, a federação foi extinta. Nas Constituições

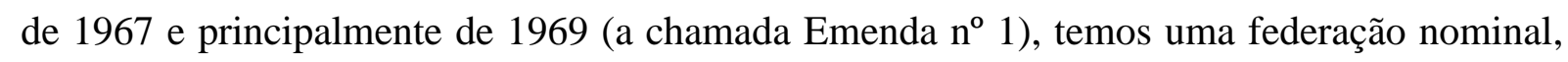
porquanto, os governadores não eram eleitos, assim como os senadores.

O nosso Estado Federal surgiu, assim, a partir de um estado unitário, criado pela Constituição de 1824, o que ajuda a compreender a nossa tradição centralizadora, inclusive, no que pertine a distribuição das receitas tributárias.

A Constituição de 1988 restaura a federação e a democracia, procurando avançar através de um novo federalismo centrífugo (que busca a descentralização) e de três níveis (incluindo uma terceira esfera de poder político: o município). Entretanto, apesar das inovações, o número de competências destinadas à União em detrimento dos estados e municípios é muito grande, fazendo com que se tenha um modelo federativo ainda marcadamente centralizador.

A partir da Constituição de 1988, os municípios brasileiros não só mantêm sua autonomia formal como conquistam a posição de ente federado, podendo, portanto, elaborar suas Constituições municipais (chamadas pela Constituição Federal de leis orgânicas), eleger seus próprios representantes políticos e auto-organizar os seus poderes executivos e legislativo, promulgando suas leis sem que seja possível ou permitida a intervenção do legislativo estadual ou federal para a respectiva aprovação.

Para assegurar a autonomia dos entes federativos, núcleo do equilíbrio federativo, o legislador constituinte originário estabeleceu, no próprio texto constitucional, mecanismos que visam proteger o modelo por ele desenhado. Entres os quais está a repartição das receitas tributárias, prevista nos arts. 157 a 159 da CF/88. Ao estabelecer a obrigatoriedade da repartição das receitas de tributos entre os entes federados, buscou o legislador constituinte assegurar uma relativa equivalência econômico-financeira entre eles, aspecto fundamental para o equilíbrio federativo. 
Entretanto, mesmo depois do advento da $\mathrm{CF} / 88$, há uma crítica generalizada quanto ao fato da União dispor de quase $60 \%$ da carga tributária nacional.

Segundo Bremaeker (2007), Tabela 2, a evolução desde 1960 até 2005 da distribuição federativa dos recursos disponíveis, ou seja, após a contabilização das transferências constitucionais e daquelas de caráter voluntário, oriundas de convênios, mostra que em 1960 a União dispunha de 59,5\% de todos os recursos arrecadados no País, contra 34,1\% de posse dos Estados e 6,4\% com os Municípios.

No qüinqüênio seguinte, os Municípios conseguiram um significativo avanço, alcançando a marca dos 10,1\% cinco anos depois, conseguindo manter esta participação até o início da década de 70. Na década seguinte a participação dos Municípios caiu em 1,4 ponto percentual.

Pouco antes da promulgação da Constituição de 1988 os Municípios tiveram sua participação elevada para $11,1 \%$, graças às elevações dos percentuais de repasse dos impostos da União que compõem o Fundo de Participação dos Municípios, subindo para 13,5\% dois anos após a promulgação da referida Constituição.

Entre 1995 e 2005 os Municípios ultrapassaram o percentual de 16\% das receitas correntes disponíveis para os entes federados.

Tabela 2

Distribuição Federativa dos Recursos Disponíveis para cada um dos Entes Federados do

ANOS

ANOS

1960

1965

1970

1975

1980

1985

1990

1995

2000

2005

UNIÃO

(\%)

59,5

54,8

60,8

68,0

68,1

62,7

58,9

56,2

56,7

55,2
Brasil - 1960 a 2005

ESTADOS

(\%)

34,1

35,1

29,2

23,3

23,3

26,2

27,6

27,2

26,4

28,4
MUNICÍPIOS

(\%)

6,4

10,1

10,0

8,7

8,6

11,1

13,5

16,6

16,9

16,4

Fontes: VERSANO et al - in: AFONSO, José Roberto R. e ARAÚJO, Erika Amorim. (1960 a 2000) MINISTÉRIO DA FAZENDA. Secretaria do Tesouro Nacional (classificação das receitas ajustada pelo Banco de Dados Municipais do IBAM - IBAMCO) (2005).

Elaboração: Bremaeker (2007, p. 14) 


\section{Composição das receitas municipais}

As receitas municipais podem ser agrupadas em três categorias: as receitas tributárias, as receitas de transferências e as outras receitas.

As receitas tributárias compreendem: os seus impostos (Imposto Predial e Territorial Urbano - IPTU, Imposto sobre Serviços de qualquer Natureza - ISS e Imposto sobre a Transmissão de Bens Imóveis inter vivos - ITBI), as taxas (de poder de polícia e pela prestação de serviços) e a contribuição de melhoria.

As receitas de transferências correspondem às transferências constitucionais, legais e voluntárias, a saber: a cota-parte do Fundo de Participação dos Municípios (FPM), o Imposto de Renda Retido na Fonte (IRRF), a cota-parte do Imposto Territorial Rural (ITR), a cotaparte do IOF-Ouro, a cota-parte na compensação pela desoneração do ICMS nas exportações de produtos primários e semi-elaborados (LC 86/97), a cota-parte do Imposto sobre a Circulação de Mercadorias e Serviços (ICMS), a cota-parte do Imposto sobre a Propriedade de Veículos Automotores (IPVA), a cota-parte do IPI-Exportação, a cota-parte da Compensação Financeira de Extração Mineral (CFEM) e a cota-parte do Fundo Especial do Petróleo (FEP), além dos recursos provenientes do Sistema Único de Saúde (SUS), do Fundo de Manutenção e Desenvolvimento da Educação Básica e de Valorização dos Profissionais da Educação (FUNDEB), do Fundo Nacional de Assistência Social (FNAS), do Fundo Nacional do Desenvolvimento da Educação (FNDE), a cota-parte do salário-educação, as transferências dos Municípios, as transferências oriundas de convênios da União, dos Estados, dos Municípios e de outras instituições públicas, além das demais transferências correntes e de capital da União, dos Estados e de instituições públicas.

As outras receitas compreendem: as receitas de contribuições, patrimonial, agropecuária, industrial, de serviços, a Contribuição para o Custeio da Iluminação Pública (COSIP), as transferências de instituições privadas (pessoais, do exterior ou de convênios), as receitas de dívida ativa, multas e juros de mora e de indenizações e restituições, as demais receitas correntes e as receitas de capital (operações de crédito, alienação de bens, amortização de empréstimos, transferências de capital de instituições privadas e outras receitas de capital) 
Enquanto nas receitas tributárias o Município exerce o poder de tributar, nas receitas partilhadas o que ocorre é a participação do Município, de acordo com critérios predeterminados, no produto da arrecadação de tributos de competência exclusiva da União e do Estado.

No âmbito estadual, dispõe a Constituição Federal que, da arrecadação do Imposto sobre Circulação de Mercadorias e Serviços - ICMS, 75\% (setenta e cinco por cento) constituem receita do Estado e 25\% (vinte e cinco por cento), receita do Município.

Do produto da arrecadação do Imposto de Renda e do Imposto sobre Produtos Industrializados - IPI, a União distribui $22,5 \%$ (vinte e dois vírgula cinco por cento) aos Municípios através do Fundo de Participação dos Municípios - FPM. A participação de cada Município é determinada pela aplicação de coeficientes variáveis de acordo com o número de habitantes e da renda per capita, ambos repassados pelo IBGE Ao Tribunal de Contas da União (TCU).

De acordo com Bremaeker (2007), a composição das receitas dos municípios do Brasil, em 2005, mostrava que 18,9\% dos seus recursos eram provenientes de suas receitas tributárias, enquanto que $66,3 \%$ provinham das transferências e $14,8 \%$ das outras receitas.

Alerta o referido autor que esta distribuição não se mantém homogênea para todos os municípios. Como os municípios têm à sua disposição impostos de base tributária urbana (ISS e IPTU), as receitas tributárias dos municípios de menor porte demográfico são pouco expressivas, a torná-los ainda mais dependentes das transferências de receitas dos estados e da União.

Os municípios com população até 10 mil habitantes, que representam quase a metade do número de municípios do país, sua receita tributária própria não alcança $5 \%$ do total das suas receitas. Até mesmo os municípios com população até 50 mil habitantes, que representam em torno de $90 \%$ do número de municípios do país, sua receita tributária não alcança $10 \%$ da receita total. Apenas os municípios com população acima de 200 mil habitantes ultrapassam a participação média de receita tributária. Mesmo assim, os dois municípios com população superior a 5 milhões de habitantes (São Paulo e Rio de Janeiro), arrecadam, em média, $41 \%$ do total de recursos disponíveis. 
Tabela 3

Participação Relativa das Receitas Municipais segundo os Grupos de Habitantes no Ano

\begin{tabular}{|c|c|c|c|c|}
\hline $\begin{array}{c}\text { GRUPOS } \\
\text { DE } \\
\text { HABITANTES } \\
\text { (por mil) }\end{array}$ & $\begin{array}{c}\text { RECEITA } \\
\text { ORÇAMENTÁRIA } \\
\text { TOTAL } \\
(\%)\end{array}$ & $\begin{array}{c}\text { de } 2005(*) \\
\text { RECEITAS } \\
\text { TRIBUTÁRIAS } \\
(\%)\end{array}$ & $\begin{array}{c}\text { RECEITAS } \\
\text { DE } \\
\text { TRANSFERÊNCIAS } \\
(\%)\end{array}$ & $\begin{array}{c}\text { OUTRAS } \\
\text { RECEITAS } \\
(\%)\end{array}$ \\
\hline TOTAL & 100,00 & 18,9 & 66,3 & 14,8 \\
\hline até 2 & 100,00 & 2,0 & 92,8 & 5,2 \\
\hline $2 \mid--5$ & 100,00 & 2,9 & 91,7 & 5,4 \\
\hline $5 \mid-10$ & 100,00 & 4,6 & 88,9 & 6,6 \\
\hline $10 \mid-20$ & 100,00 & 5,3 & 88,4 & 6,3 \\
\hline $20 \mid--50$ & 100,00 & 8,1 & 82,1 & 9,9 \\
\hline $50 \mid--100$ & 100,00 & 13,4 & 73,7 & 12,8 \\
\hline $100 \mid--200$ & 100,00 & 15,2 & 67,4 & 17,4 \\
\hline $200 \mid--500$ & 100,00 & 22,2 & 60,6 & 17,2 \\
\hline $500 \mid--1000$ & 100,00 & 21,8 & 60,0 & 18,3 \\
\hline 1000 I-- 5000 & 100,00 & 27,9 & 49,9 & 22,2 \\
\hline 5000 e mais & 100,00 & 41,0 & 38,9 & 20,1 \\
\hline
\end{tabular}

FONTE: Ministério da Fazenda. Secretaria do Tesouro Nacional - 2005. TABULAÇÕES ESPECIAIS: IBAM. Banco de Dados Municipais (IBAMCO). Elaboração: Bremaeker (2007, p. 16)

(*) Dados expandidos a partir de uma amostra de 4.131 Municípios para um total de 5.562 municípios. Não são considerados os dados referentes ao Distrito Federal e Fernando de Noronha.

Assim, conclui Bremaeker (2007), que as transferências constitucionais representam a principal fonte de receita da maioria dos municípios brasileiros. Os municípios com população até 10 mil habitantes têm nas transferências mais de $90 \%$ das suas receitas. Os municípios com população até 50 mil habitantes ainda registram a marca de mais de $80 \%$ de receita de transferências.

Os dados da Tabela 3 levam à inferência de que, se as transferências constitucionais mostram-se mais significativos à sustentabilidade dos municípios de baixa densidade demográfica, tem-se reforçada a idéia da maior relevância do pagamento de benefícios previdenciários para a sustentabilidade da economia dos municípios do Rio Grande do Norte, pois a expressiva maioria destas localidades, com população até 10.000 habitantes, percebem renda dos benefícios previdenciários em volume superior aos recursos decorrentes das receitas próprias e, também em considerável parte, das transferências constitucionais. 


\section{Abordagem de pesquisas sobre o impacto da Previdência Social na economia dos municípios}

Não são muitos os estudos sobre o impacto redistributivo da Previdência Social na economia dos municípios brasileiros. Entre os existentes, destacam-se três trabalhos: a) de Álvaro Sólon de França (2004), que mostra o impacto do pagamento dos benefícios previdenciários nos municípios do Brasil, b) de Marcelo Caetano (2008), que analisa como a Previdência Social brasileira afeta a distribuição de renda do ponto vista regional, mais especificamente, municipal; e c) de Rogério Nagamine Costanzi e Edvaldo Duarte Barbosa (2009) que demonstram a influência da Previdência Social na movimentação das economias locais das pequenas municipalidades mediante análise comparativa com o FPM e o PIB.

Em seu trabalho, França (2004), ressaltou que milhares de municípios apresentavam o montante de pagamento de benefícios superior ao FPM. Segundo o referido estudo, a quantidade de benefícios rurais emitidos beneficiou, em 2003, indiretamente, em torno de 24 milhões de pessoas no campo, em uma população total de 31,8 milhões, de acordo com o Censo Populacional do IBGE/2000. Essas pessoas pouco ou nada contribuíram diretamente para a Previdência Social, o que, conforme cita o autor, indica que a instituição funciona como um verdadeiro programa de renda mínima para os idosos no Brasil, principalmente nas Regiões Norte e Nordeste.

Engana-se quem supõe que o maior volume de pagamentos de benefícios previdenciários em relação ao FPM é um fenômeno estritamente nordestino. De acordo com França (2004), em 2003, do total de 5.561 municípios brasileiros pesquisados, 3.773 apresentaram o pagamento de benefícios previdenciários superior ao FPM, o que significa uma participação de $67,85 \%$ do total. Conforme a pesquisa, nas regiões Norte e Nordeste, os recordes ficaram, respectivamente, por conta dos estados do Pará, onde 80 dos 143 municípios tinham pagamento de benefícios previdenciários em montante superior ao valor recebido pelo FPM, o que representava 55,94\%, e Pernambuco, com 160 dos 185 municípios nessa situação, $86,49 \%$ do total. As regiões Sudeste e Sul também apresentavam percentuais expressivos, com destaque para o estado do Rio de Janeiro, que em 84 dos 92 municípios o pagamento de benefícios previdenciários superava o FPM, o que representava 91,30\%, no Espírito Santo isto se verificava em 74 dos 78 municípios (94,87\%), e em São Paulo, maior 
estado arrecadador, em 519 dos 645 municípios (80,47\%). Na Região Sul o maior percentual era no Paraná: de 399 municípios, 305 conviviam com essa realidade, ou 76,44\%.

A pesquisa de França (2004) também apontou que, em 2003, o pagamento de benefícios previdenciários, em relação ao Produto Interno Bruto (PIB), correspondia a 17,17\% no Piauí; 15,16\% no Maranhão; 13,66\% na Paraíba; 12,66\% no Ceará; 11,45\% em Alagoas; $11,23 \%$ no Rio Grande do Norte; $10,51 \%$ em Pernambuco; 9,44\% na Bahia; 8,12\% em Minas Gerais; 8,11\% em Tocantins; 7,98\% no Acre; 7,69\% em Sergipe; 7,63\% no Rio Grande do Sul; 7,25\% no Rio de Janeiro; 7,00\% em Santa Catarina e 6,46\% em São Paulo.

Outro ponto que a pesquisa ressalta é a comparação do pagamento dos benefícios com o Índice Municipal de Desenvolvimento Humano (IDH-M), que diz que dos 100 municípios melhor situados com o IDH-M, em 92 deles o pagamento de benefícios era superior ao FPM. Já nos 100 piores o número de municípios com benefícios previdenciários em volume superior ao FPM caía para 28. Em 94 dos 100 municípios onde o IDH de renda é maior, o pagamento de benefícios é superior ao FPM, enquanto somente em 36 dos 100 municípios com pior IDH de renda o pagamento de benefícios é superior ao FPM.

O estudo feito por Caetano (2008) afirma que a previdência seria progressiva tanto do ponto de vista funcional quanto regional. No funcional, seria decorrência do fato da rentabilidade das pessoas de menor rendimento superar à observada para os indivíduos de maior remuneração, ou seja, existe uma tendência de quanto menor a remuneração obtida pelo trabalhador em atividade maior ganho financeiro proporcionará sua aposentadoria ${ }^{19}$. Seria também progressiva do ponto de vista regional tendo em vista distribui renda dos municípios mais ricos em direção aos mais pobres (considerando apenas o Regime Geral de Previdência Social - RGPS e sem considerar os Regimes Próprios, até porque não faria sentido tal análise, pois esses últimos ficam circunscritos a cada município). Em 2006, haveria 1.971 municípios que não exibiram contribuição previdenciária alguma (a maioria das cidades têm pagamentos de benefícios) e apenas 148 apresentaram superávit.

\footnotetext{
${ }^{19}$ Esta hipótese é facilmente confirmada junto à clientela rural, pois é muito comum que a aposentadoria proporcione o percebimento de renda regular e significativamente superior ao que o segurado especial obteria através da atividade de rurícola, por mais das vezes, exercida de forma precária.
} 
O estudo feito por Caetano (2008) testou a progressividade regional do RGPS por meio de um modelo econométrico que utilizou dados municipais do Sistema de Informações Socioeconômicas dos Municípios Brasileiros (Simbrasil), que é resultado de uma cooperação entre a Associação Nacional de Pós-Graduação em Economia (ANPEC), Instituto de Pesquisa Econômica Aplicada (IPEA) e Caixa Econômica Federal (CEF), e informações do Ministério da Previdência Social.

A conclusão é que a Previdência Social (RGPS) é um potencial instrumento de distribuição de renda das regiões mais afluentes para as mais necessitadas. Outro dado apresentado pelo estudo (Caetano, 2008), que corrobora essa conclusão, é o fato da previdência distribuir renda de forma mais igualitária que a observada pela economia (PIB). Dito de outra forma, enquanto o Índice de Gini do benefício médio previdenciário é de 0,12 , o do PIB per capita municipal é de 0,44 e, portanto, a distribuição do PIB per capita é quase quatro vezes mais desigual que a previdenciária.

Caetano (2008), contudo, coloca a ressalva de que o efeito positivo da Previdência sobre as desigualdades regionais seria de curto prazo e não atacaria o problema de forma estrutural ou dinâmica e que seria mais eficiente a utilização dos escassos recursos públicos de outras formas e/ou em outros setores (educação/infra-estrutura) que tivessem maior potencial para dinamizar as economias locais no longo prazo.

A respeito desta ressalva, ponderam Costanzi e Barbosa (2009, p. 97 e 98) que

(...) as transferências governamentais para a população idosa podem ter, por meio das transferências no âmbito das famílias, impactos relevantes na qualidade da educação dos netos e/ou no estímulo de investimentos pelo maior dinamismo das economias locais. Nesse sentido, as transferências governamentais podem ter efeitos de longo prazo. O efeito atenuador de curto prazo nas desigualdades regionais e na pobreza é de extrema importância social, sem gerar, necessariamente, a perpetuação da pobreza local e uma suposta dependência das transferências previdenciárias.

Costanzi e Barbosa (2009), buscando introduzir inovações em suas análises, organizam sua pesquisa com base nos seguintes procedimentos: (a) relação da arrecadação, pagamento de benefícios e benefícios líquidos da Previdência Social com o PIB dos municípios; (b) análise de arrecadação, pagamento de benefícios e benefícios líquidos em relação ao PIB para capitais das UFs $\mathrm{x}$ demais cidades e regiões metropolitanas $\mathrm{x}$ não 
metropolitanas; (c) na análise do perfil dos municípios de acordo com sua situação em termos da relação entre arrecadação e valor dos benefícios emitidos; (d) descrição da redistribuição de renda por meio da Previdência Social entre as UFs e regiões do país; (e) comparação do valor dos benefícios com as transferências do FPM.

Na primeira abordagem metodológica, consistente na avaliação da arrecadação e despesas da Previdência Social, por décimo ${ }^{20}$ de municípios ordenados pelo PIB per capita, verificou a pesquisa que em todos os décimos, exceto aquele dos municípios de PIB per capita mais elevado, prevaleceu um montante de pagamentos de benefícios superior às receitas. No décimo de PIB per capita mais elevado, ao contrário, o valor arrecado foi superior ao montante de gastos com pagamento de benefícios, denotando um primeiro aspecto redistributivo da Previdência Social. Os dados utilizados foram de 2006, tendo em vista ser o ano mais recente com informações disponíveis para o PIB das cidades (utilizando os dados do IBGE).

Para Costanzi e Barbosa (2009), o caráter da Previdência Social como mecanismo de redistribuição de renda dos municípios mais ricos para os mais pobres fica claro quando se faz a comparação do valor líquido dos benefícios (despesas - receitas) com o valor do PIB desses municípios. Enquanto no décimo dos municípios mais ricos, há um excesso de arrecadação da ordem de R \$ 15,1 bilhões ou 1,1\% do PIB dessas municipalidades, no décimo dos mais pobres, há um excesso de benefícios em relação à arrecadação da ordem de $\mathrm{R}$ \$,6 bilhões, que corresponde a $17,1 \%$ do PIB desses municípios ${ }^{21}$. Claramente, como pode ser visto pelos dados da Tabela 4 e do Gráfico 8, há uma relação inversamente proporcional entre PIB per capita do município e relação pagamento de benefícios líquidos (descontado a arrecadação)/PIB.

\footnotetext{
${ }^{20}$ Explicam os autores da pesquisa que a regra geral é que cada decil tenha 556 municípios. Contudo, tendo em vista a existência de 5.564 municípios, restariam 4. Como forma de ajuste esses 4 municípios adicionais foram incluídos, de forma arbitrária, no $2^{\circ}, 4^{\circ}, 6^{\circ}$ e $8^{\circ}$ decil. Tal fato, argumentam os autores, altera de forma muito pouco significativa os resultados obtidos.

${ }^{21}$ Considerando que o inciso $\mathrm{X}$, do art. 167, da CF, veda a utilização dos recursos provenientes das contribuições de que trata o art. 195, I, $a$, e II (pagas pelo empregador sobre folha de salários e pelo trabalhador também sobre sua verba salarial), para a realização de despesas distintas do pagamento de benefícios do RGPS, pode-se dizer que o excesso de arrecadação previdenciária verificada nos municípios de maior PIB necessariamente é redistribuído para os municípios de menor PIB, pois estes têm forte déficit na relação arrecadação previdenciária/despesa previdenciária.
} 


\section{Tabela 4}

Arrecadação* e Pagamento de Benefícios** da Previdência Social por Décimos de Municípios Ordenados por PIB per capita Valores em R\$ correntes Milhões - 2006

\begin{tabular}{|c|c|c|c|c|c|}
\hline $\begin{array}{l}\text { Décimo por } \\
\text { PIB per capita }\end{array}$ & $\begin{array}{c}\text { Arrecadação* } \\
\text { (1) }\end{array}$ & $\begin{array}{l}\text { Pagamento de } \\
\text { Benefícios } * * \\
\text { (2) }\end{array}$ & $\begin{aligned} & (3) \\
= & (2)-(1)\end{aligned}$ & $\begin{array}{l}\text { PIB total } \\
\text { (4) }\end{array}$ & $\begin{array}{l}(3) /(4) \\
\text { em \% }\end{array}$ \\
\hline 1 & 261 & 3.871 & 3.610 & 21.139 & 17,1 \\
\hline 2 & 424 & 5.144 & 4.720 & 26.337 & 17,9 \\
\hline 3 & 700 & 6.152 & 5.452 & 34.571 & 15,8 \\
\hline 4 & 1.004 & 6.148 & 5.144 & 45542 & 11,3 \\
\hline 5 & 1821 & 9206 & 7385 & 81549 & 9,1 \\
\hline 6 & 2568 & 9435 & 6867 & 97293 & 7,1 \\
\hline 7 & 5.925 & 12.810 & 6.884 & 135.335 & 5,1 \\
\hline 8 & 7.026 & 14.047 & 7.021 & 182.175 & 3,9 \\
\hline 9 & 17.931 & 24.791 & 6.860 & 327.539 & 2,1 \\
\hline 10 & 81.861 & 66.803 & -15.058 & 1.418 .317 & $-1,1$ \\
\hline
\end{tabular}

Fonte: Elaboração CGEP/DRGPS/SPS/MPS A partir de dados do MPS e do IBGE;

* Apenas receitas tradicionalmente vinculadas a Previdência Social, não inclui receitas para cobrir necessidade de financiamento do Regime Geral da Previdência Social - RGPS;

* Inclui pagamento do BPC/LOAS, considera valor dos benefícios emitidos e não coincide exatamente com os valores do fluxo de caixa INSS.

\section{Gráfico 8}

Relação (Benefícios - Arrecadação)/PIB em \%

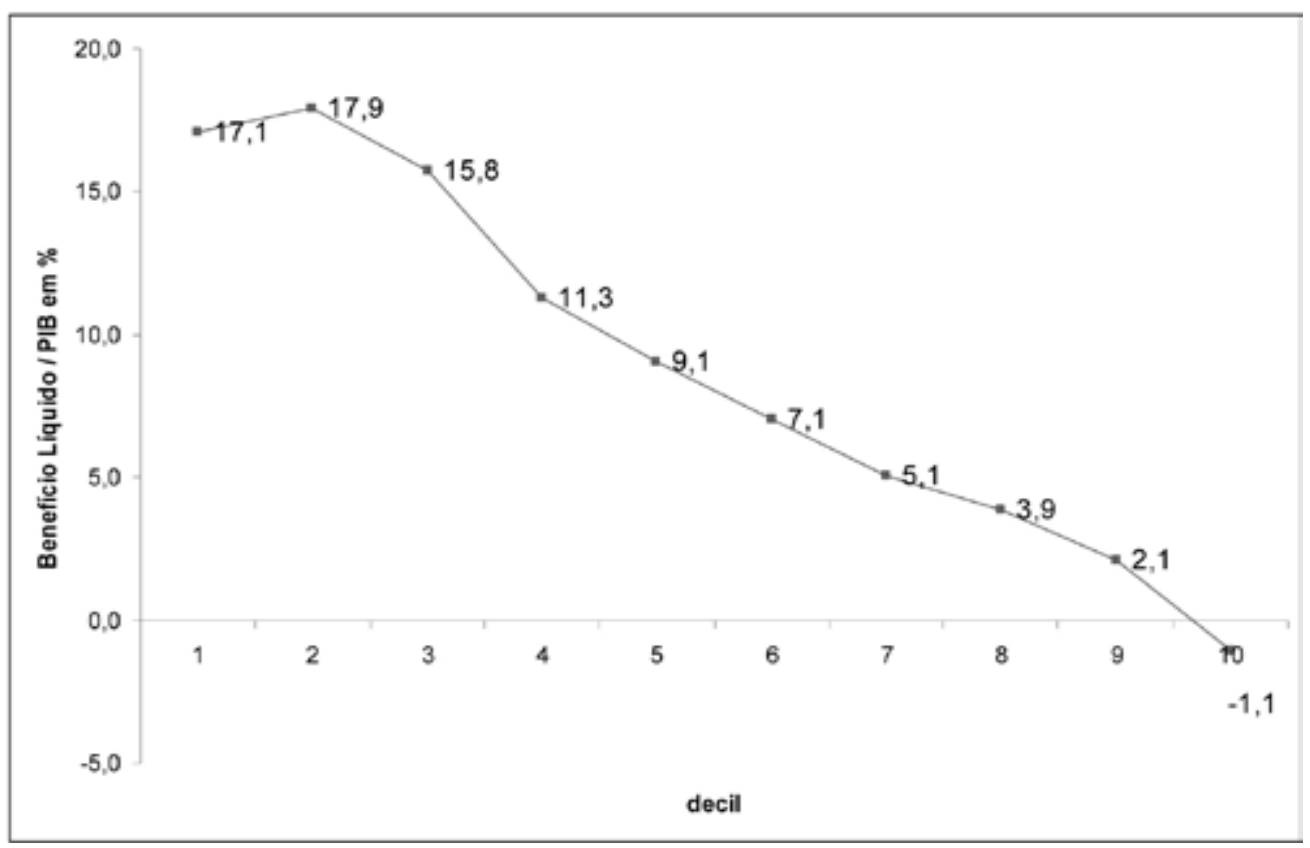

Fonte: Costanzi e Barbosa (2009), a partir de dados do MPS e do IBGE;

* Apenas receitas tradicionalmente vinculadas a Previdência Social, não inclui receitas para cobrir necessidade de financiamento do Regime Geral de Previdência Social - RGPS;

** Inclui pagamento dos Benefícios de Prestação Continuada - Lei Orgânica de Assistência Social $\mathrm{BPC} / \mathrm{LOAS}$, considera valor dos benefícios emitidos e não coincide exatamente com valores do fluxo de caixa do INSS. 
Num segundo momento, Costanzi e Barbosa (2009) analisam a arrecadação e despesa da Previdência Social por tamanho do município ou população, apurando que apenas na faixa de municípios com mais de 100 mil habitantes, há um volume de arrecadação superior ao de benefícios, em $\mathrm{R} \$ 3,4$ bilhões, o que corresponde a $0,2 \%$ do PIB dessas cidades. O maior impacto, considerado a relação benefícios líquidos/PIB, se dá para aqueles municípios com mais de 10 mil e até 20 mil habitantes, onde o pagamento de benefícios superou as despesas em cerca de $\mathrm{R} \$ 8,7$ bilhões, que representou $6,9 \%$ do PIB dessas cidades.

\section{Tabela 5}

Arrecadação* e Pagamento de Benefícios** por Tamanho da População Valores em R\$ correntes Milhões - 2006

\begin{tabular}{|c|c|c|c|c|c|}
\hline $\begin{array}{c}\text { Tamanho do } \\
\text { Município } \\
\text { (número } \\
\text { habitantes)*** }\end{array}$ & $\begin{array}{c}\text { Arrecadação* } \\
\text { (1) }\end{array}$ & $\begin{array}{c}\text { Pagamento de } \\
\text { Benefícios** } \\
\mathbf{( 2 )}\end{array}$ & $\begin{array}{c}\text { Benefícios } \\
\text { Líquidos } \\
(\mathbf{3})=\mathbf{( 2 )}-(\mathbf{1})\end{array}$ & $\begin{array}{c}\text { PIB } \\
\mathbf{( 4 )}\end{array}$ & $\begin{array}{c}\mathbf{( 3 ) /} \\
\mathbf{( 4 )} \\
\text { Em \% }\end{array}$ \\
\hline Até 5 mil & 263 & 2.152 & 1.889 & 37.690 & 5,0 \\
\hline$>5$ mil e até 10 & 1.056 & 5.326 & 4.270 & 71.276 & 6,0 \\
\hline $\begin{array}{c}>10 \text { mil e até } \\
20 \text { mil }\end{array}$ & 3.075 & 11.758 & 8.682 & 126.368 & 6,9 \\
\hline $\begin{array}{c}>20 \text { mil e até } \\
50 \text { mil }\end{array}$ & 6.646 & 22.753 & 16.108 & 256.862 & 6,3 \\
\hline $\begin{array}{c}>50 \text { mil e até } \\
100 \text { mil }\end{array}$ & 6.750 & 18.077 & 11.327 & 223.281 & 5,1 \\
\hline$>100$ mil & 101.731 & 98.341 & -3.389 & 1.654 .319 & $-0,2$ \\
\hline $\begin{array}{c}\text { Subtotal até } 100 \\
\text { mil }\end{array}$ & 17.790 & 60.066 & 42.276 & 715.478 & 5,9 \\
\hline
\end{tabular}

Fonte: Costanzi e Barbosa (2009), a partir de dados do MPS e do IBGE;

* Apenas receitas tradicionalmente vinculadas a Previdência Social, não inclui receitas para cobrir necessidade de financiamento do Regime Geral de Previdência Social - RGPS;

** Inclui pagamento do BPC/LOAS, considera valor dos benefícios emitidos e não coincide exatamente com valores do fluxo de caixa do INSS;

*** estimado pela divisão do PIB pelo PIB per capita da publicação do IBGE do PIB dos municípios em 2006.

Explicam os autores referidos que a análise de correlação entre população do município e a relação (benefício líquido/PIB) se mostrou significativa a $1 \%$, mas com um coeficiente baixo $(-0,056)$ e inferior ao verificado com o PIB per capita $(-0,265)$, de modo que embora se possa argumentar que quanto menor a cidade maior tende a ser a relação (benefício líquido / PIB), na realidade, a referida relação é mais negativamente correlacionada com o PIB per capita. Querem dizer com isso os autores que, do ponto de vista estatístico, é mais correto dizer que um município com baixo PIB per capita tende a ter uma elevada relação (benefício líquido/PIB) do que um município com baixa densidade demográfica tende a ter essa referida relação elevada. 
Assim, concluem os pesquisadores que a Previdência Social distribui mais renda entre cidades com alto PIB per capita para aquelas com baixo PIB per capita, do que de grandes cidades para pequenos municípios (em termos de população), embora esse último impacto também exista (de cidades com mais de 100 mil habitantes para aquelas com uma população até 100 mil habitantes).

Outra análise empreendida por Costanzi e Barbosa (2009), dar-se comparando a arrecadação e despesa das capitais das UFs e DF x demais cidades. Cotejando a situação das capitais das 27 Unidades da Federação e o Distrito Federal em relação às demais cidades concluíram os autores que há uma redistribuição de renda das primeiras cidades para as últimas. Como pode ser visto pela Tabela 6, nas capitais e DF a arrecadação supera o pagamento de benefícios em $\mathrm{R} \$ 23,5$ bilhões, que representou, em 2006, 1,5\% do PIB dessas cidades. Já nas demais cidades do país, o pagamento de benefícios é maior que a arrecadação em $\mathrm{R} \$ 62,4$ bilhões, que representou, em 2006, uma injeção de 7,7\% do PIB dessas cidades.

Tabela 6

Arrecadação* e Pagamento de Benefícios** Capitais das UFs x Demais Cidades Valores em R\$ correntes Milhões - 2006

\begin{tabular}{|c|c|c|c|c|c|}
\hline $\begin{array}{c}\text { Capitais das } \\
\text { UFs x Demais } \\
\text { Cidades }\end{array}$ & $\begin{array}{c}\text { Arrecadação* } \\
\text { (1) }\end{array}$ & $\begin{array}{c}\text { Pagamento de } \\
\text { Benefícios** } \\
(\mathbf{2})\end{array}$ & $\begin{array}{c}\text { Benefícios } \\
\text { Líquidos } \\
(3)=(2)-(1)\end{array}$ & $\begin{array}{c}\text { PIB } \\
\text { (4) }\end{array}$ & $\begin{array}{c}\text { (3) / (4) } \\
\text { Em \% }\end{array}$ \\
\hline $\begin{array}{c}\text { Capitais das } \\
\text { UF's e DF }\end{array}$ & 70.785 & 47.251 & -23.533 & 1.554 .214 & $-1,5$ \\
\hline $\begin{array}{c}\text { Demais } \\
\text { Cidades }\end{array}$ & 48.736 & 111.157 & 62.420 & 815.582 & 7,7 \\
\hline
\end{tabular}

Fonte: Costanzi e Barbosa (2009), a partir de dados do MPS e do IBGE;

* Apenas receitas tradicionalmente vinculadas a Previdência Social, não inclui receitas para cobrir necessidade de financiamento do Regime Geral de Previdência Social - RGPS;

** Inclui pagamento do BPC/LOAS, considera valor dos benefícios emitidos e não coincide exatamente com valores do fluxo de caixa do INSS;

Seguindo na exposição da pesquisa de Costanzi e Barbosa (2009), verificaram estes pesquisadores que de um total de 5.564 municípios existentes no Brasil, em 2006, apenas 159 (2,9\% do total) tinham um volume de arrecadação tradicionalmente vinculada à Previdência é superior ao pagamento de benefícios, a sugerir transferência de renda desses 159 municípios para os demais 5.405. Os municípios com maior excesso de arrecadação em relação ao valor dos benefícios emitidos eram, por ordem de grandeza (do maior superávit para o menor): São Paulo, Brasília, Rio de Janeiro, Belo Horizonte, Curitiba, Porto Alegre, Campinas, Barueri, 
Joinvile, Goiânia, Manaus, Caarapó (MS), Vitória, Osasco, Florianópolis, Macaé, Cuiabá, Palmas e Camaçari. Claramente, há predomínio de grandes cidades e/ou com grande parque produtivo.

E, em termos regionais, apontam haver redistribuição de renda da região Centro-Oeste para as demais, em especial, por conta do resultado do DF. Na região Sudeste, em princípio não ocorre redistribuição porque há excesso do valor dos benefícios emitidos em relação a arrecadação dos estados do ES, MG e RJ superior ao superávit apresentado pelo estado de SP, sendo que tal resultado foi obtido sem considerar o total das receitas. A maior relação valor dos benefícios emitidos/PIB, para o ano de 2006, observou-se para a Região Nordeste (10,54\% do PIB da região), com UFs onde tal valor chegou a valores ainda maiores $(13,96 \%$ do PIB para o Piauí, 13,13\% para a Paraíba, 10,99\% Ceará, 10,89\% Pernambuco e 10,83\% para o Maranhão). Depois vieram as Regiões Sul (7,17\% do PIB), Sudeste (6,34\%), Norte $(4,67 \%)$ e, o menor nível, para a região Centro-Oeste (3,39\% do PIB). Em termos de arrecadação o maior nível, em relação ao PIB, foi observado para a região Sudeste $(5,71 \%$ do PIB) e o menor para a Norte (3,20\% do PIB), sendo que foram apenas consideradas as receitas mais tradicionalmente vinculadas a Previdência. Quanto aos benefícios líquidos (pagamento de benefícios - arrecadação) em \% do PIB, a maior relação se deu para a Região Nordeste $(7,04 \%)$ e a menor para a Sudeste $(0,63 \%)$ e Centro-Oeste $(-1,13 \%)$, sendo que esse último caso se explica principalmente pela relação no DF (- 6,97\% do PIB).

\section{Tabela 7}

Arrecadação e Valor dos Benefícios Emitidos por Região 2006 Valores em R\$ milhões correntes ou nominais ou em \%

\begin{tabular}{|c|c|c|c|c|c|c|c|}
\hline Região & $\begin{array}{l}\text { Arrecadaçãa } \\
\text { em R\$ } \\
\text { milhões } \\
\text { (a) }\end{array}$ & $\begin{array}{c}\text { Benefícios } \\
\text { em R\$ } \\
\text { mihões } \\
\text { (b) }\end{array}$ & $\begin{array}{c}(\mathbf{c})=(\mathbf{b})- \\
(\mathbf{a}) \\
\text { em R\$ } \\
\text { milhões }\end{array}$ & $\begin{array}{c}\text { PIB em R\$ } \\
\text { milhões } \\
\text { (d) }\end{array}$ & $\begin{array}{l}\text { (a) / } \\
\text { (d) em } \\
\%\end{array}$ & $\begin{array}{c}\text { (b) / } \\
\text { (d) em } \\
\%\end{array}$ & $\begin{array}{l}\text { (c) / } \\
\text { (d) } \\
\text { em } \\
\%\end{array}$ \\
\hline NORTE & $3.835,5$ & $5.606,4$ & $1.770,9$ & $120.013,9$ & 3,20 & 4,67 & 1,48 \\
\hline NORDESTE & $10.901,8$ & $32.803,6$ & $21.901,8$ & $311.175,0$ & 3,50 & 10,54 & 7,04 \\
\hline $\begin{array}{c}\text { CENTRO- } \\
\text { OESTE }\end{array}$ & $9.330,7$ & $7.005,8$ & $-2.324,8$ & $206.360,9$ & 4,52 & 3,39 & $-1,13$ \\
\hline SUL & $18.676,3$ & $27.746,9$ & $9.070,7$ & $386.737,0$ & 4,83 & 7,17 & 2,35 \\
\hline SUDESTE & $76.776,7$ & $85.245,0$ & $8.468,3$ & $1.345 .509,8$ & 5,71 & 6,34 & 0,63 \\
\hline TOTAL* & $130.448,6$ & $158.407,8$ & $27.959,2$ & $2.369 .796,5$ & 5,50 & 6,68 & 1,18 \\
\hline
\end{tabular}

Fonte: Costanzi e Barbosa (2009), a partir de dados do MPS e do IBGE;

* inclui arrecadação com vinculação municipal/estadual ignorada. 
Por último, Costanzi e Barbosa (2009) comparam os benefícios da Previdência Social e o FPM, concluindo que, em 2006 e 2008, os benefícios pagos pela Previdência Social superam os repasses do FPM em mais de $60 \%$ dos municípios brasileiros e por região esse percentual chega ao patamar de $70 \%$ nas regiões Sul e Sudeste, conforme Tabela 8.

\section{Tabela 8}

Municípios por Região em que o pagamento de benefícios supera o FPM em 2006 e 2008

\begin{tabular}{|c|c|c|c|c|c|c|}
\hline \multirow[t]{3}{*}{ Região } & \multirow{3}{*}{$\begin{array}{c}\text { Total } \\
\text { de } \\
\text { Municípios }\end{array}$} & \multicolumn{4}{|c|}{ Municípios em que os benefícios superam o FPM } & \multirow{3}{*}{$\begin{array}{c}\% \\
2008 / 2006\end{array}$} \\
\hline & & \multicolumn{2}{|l|}{2006} & \multicolumn{2}{|c|}{2008} & \\
\hline & & Quantidade & $\%$ & Quantidade & $\%$ & \\
\hline Norte & 449 & 186 & 41,4 & 181 & 40,3 & $-2,7$ \\
\hline Nordeste & 1.793 & 1.098 & 61,2 & 1.036 & 57,8 & $-5,6$ \\
\hline Centro-Oeste & 466 & 247 & 53,0 & 239 & 51,3 & $-3,2$ \\
\hline Sudeste & 1.668 & 1.211 & 72,6 & 1.166 & 69,9 & $-3,7$ \\
\hline Sul & 1.188 & 863 & 72,6 & 827 & 69,9 & $-4,2$ \\
\hline Total & 5.564 & 3.605 & 64,8 & 3.449 & 62,0 & $-4,3$ \\
\hline
\end{tabular}

Fonte: Costanzi e Barbosa (2009), a partir de dados do MPS e do IBGE;

Apontam Costanzi e Barbosa (2009) que a relação entre pagamento benefícios e transferência de FPM, mesmo com a alta elevação do FPM provocado pelo desempenho vivido pela economia em 2008, mantém-se, na comparação com 2006, praticamente estável para a Região Norte e Nordeste, com ligeira queda de 2,1 para 1,9 e 3,2 para 2,7, respectivamente. Já na Região Sudeste e Sul essa relação passa, respectivamente, de 9,2 para 7,7 e 5,4 para 4,6 (Gráfico 9).

\section{Gráfico 9}

Relação entre Benefícios Pagos e Transferência de FPM por Região em 2006 e 2008

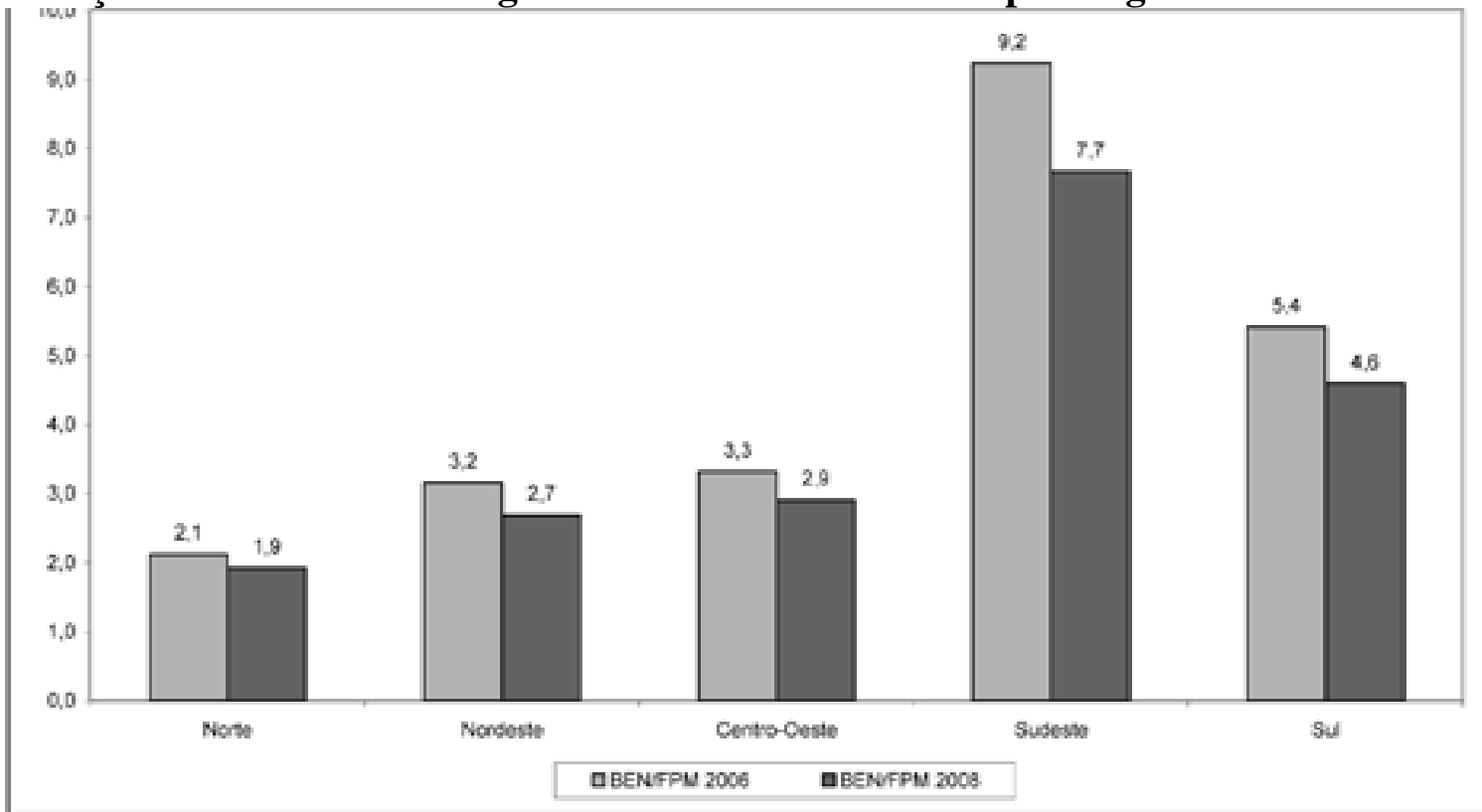

Fonte: Costanzi e Barbosa (2009), a partir de dados do MPS e do IBGE. 
Outro aspecto que não foge à análise de Costanzi e Barbosa (2009) diz respeito à caracterização dos municípios onde os benefícios superam as transferências do FPM. Apurou a pesquisa que, em 2006, os 3.605 municípios para os quais o pagamento de benefícios da Previdência superava o FPM receberam, em média, R \$ 43,3 milhões do INSS contra R \$ 6,5 milhões do FPM, gerando uma proporção de aproximadamente $\mathrm{R} \$$ 6,60 em benefícios previdenciários para cada R \$1,00 transferido pelo FPM. Essas cidades tinham em média uma população de aproximadamente 48 mil habitantes e agregavam 172,2 milhões de pessoas (92,2\% da população total do país). Em 2008, para os 3.449 municípios para os quais o pagamento de benefícios superava o FPM, a média de recebimentos do INSS foi de R $\$ 54,3$ milhões contra $\mathrm{R}$ 9,7 milhões do FPM (diferença de $\mathrm{R} \$ 44,6$ milhões).

\section{Aspectos socioeconômicos do RN}

De acordo com o último censo divulgado pelo IBGE em 2006, o Rio Grande do Norte tem população de 3.050.935 habitantes, dos quais 2.209.253 residem em área urbana e 841.682 em área rural. A População Economicamente Ativa (PEA) é de 1.799.075 habitantes, considerando-se ocupados 1.661 .893 e desocupados 137.182 .

Ainda de acordo com o último censo do IBGE, apenas três municípios no Rio Grande do Norte têm mais de 150 mil habitantes, são eles: Natal (capital, com 774.230 habitantes), Mossoró (234.390 habitantes) e Parnamirim (172.751 habitantes). Com mais de 50 mil habitantes são cinco os municípios: São Gonçalo do Amarante (77.363 habitantes), CearáMirim (65.450 habitantes), Macaíba (63.337 habitantes), Caicó (60.656 habitantes) e Assú (51.262 habitantes).

Seguem adiante os Quadros 4 a 11 descrevendo as principais informações socioeconômicas do Estado do Rio Grande do Norte.

\section{Quadro 4}

DADOS GEOGRÁFICOS E POPULACIONAIS

$\begin{array}{ll}\text { Capital } & \text { Natal }\end{array}$

$\begin{array}{ll}\text { Área }\left(\mathrm{km}^{2}\right) & 52.797\end{array}$

$\begin{array}{ll}\text { Extensão da costa litorânea }(\mathrm{km}) & 410\end{array}$ 


\begin{tabular}{|ll}
\hline Número de municípios & 167 \\
Número de distritos & 183 \\
População residente no estado (milhões de pessoas) & 3.153 \\
$\quad$ Urbana & 2.270 \\
$\quad$ Rural & 884
\end{tabular}

Fonte: Instituto Brasileiro de Geografia e Estatística (IBGE), Síntese de Indicadores Sociais - 2008.

\title{
Quadro 5
}

PRODUTO INTERNO BRUTO DO ESTADO DO RIO GRANDE DO NORTE - 2007

PIB a preços de mercado ( $\mathrm{R}$ milhões)

Produto Interno Bruto per capita $(\mathrm{R} \$)$

22.926

Fonte: IBGE, Contas Regionais do Brasil

\section{Quadro 6}

\author{
ÍNDICE DE DESENVOLVIMENTO HUMANO DO ESTADO DO RIO GRANDE DO NORTE \\ IDH - 2000 \\ $0,705\left(19^{\circ}\right)$ \\ IDH - 2005 \\ $0,738\left(21^{\circ}\right)$ \\ ÍNDICE DE GINI - 2008 \\ 0,544
}

Fonte: Programa das Nações Unidas para o Desenvolvimento (PNUD)

MAPA DE POBREZA E DESIGUALDADE - MUNICÍPIOS BRASILEIROS 2003

Incidência da Pobreza

Limite inferior da Incidência da Pobreza

Limite superior da Incidência da Pobreza

Incidência da Pobreza Subjetiva

$55,91 \%$

Limite inferior da Incidência da Pobreza Subjetiva

$51,27 \%$

Limite superior da Incidência da Pobreza Subjetiva

$60,56 \%$

Fonte: IBGE, Censo Demográfico 2000 e Pesquisa de Orçamentos Familiares - POF 2002/2003.

\section{Quadro 7}

\section{EDUCAÇÃO NO ESTADO DO RIO GRANDE DO NORTE- 2008}

Taxa de Analfabetismo (\%)

Pessoas de 5 anos ou mais de idade:

Média de Anos de Estudos

Pessoas de 25 anos ou mais de idade:

Distribuição dos Estudantes por Rede de Ensino e Nível de Ensino (\%)

Fundamental

Pública

Particular

Médio

Pública

Particular

Superior

Pública

Particular

Taxa de escolarização das pessoas de $\mathbf{4}$ anos ou mais de idade

por grupos de idade $(\%)$

4 ou 5 anos

6 a 14 anos

97,1

15 a 17 anos

18 a 24 anos

25 anos ou mais

5,3

Fonte: Pesquisa Nacional por Amostra de Domicílios - 2008 / IBGE. 


\section{Quadro 8}

SAÚDE DO ESTADO DO RIO GRANDE DO NORTE - 2007

$\begin{array}{ll}\text { Número de Estabelecimentos de Saúde } & 2.503\end{array}$

Número de Postos de Saúde 346

$\begin{array}{ll}\text { Médicos por mil habitantes }^{1} & 3,20\end{array}$

$\begin{array}{lr}\text { Leitos por mil habitantes }^{2} & 2,60\end{array}$

$\begin{array}{ll}\text { Taxa de mortalidade infantil - } & 200833,50\end{array}$

Fonte: DATASUS (Banco de dados do Sistema Único de Saúde).

Fonte: Atlas do Desenvolvimento Humano no Brasil / Programa das Nações Unidas para o Desenvolvimento (PNUD).

Nota: ${ }^{1}$ Se um profissional tiver vínculo com mais de um estabelecimento, ele será contado tantas vezes quantos vínculos houver.

Nota:² Não Inclui leitos complementares( Unidades de Tratamento Intensivo, Unidades Intermediárias, Unidades de Isolamento)

Pesquisa Nacional por Amostra de Domicílio - PNAD/IBGE

Quadro 9

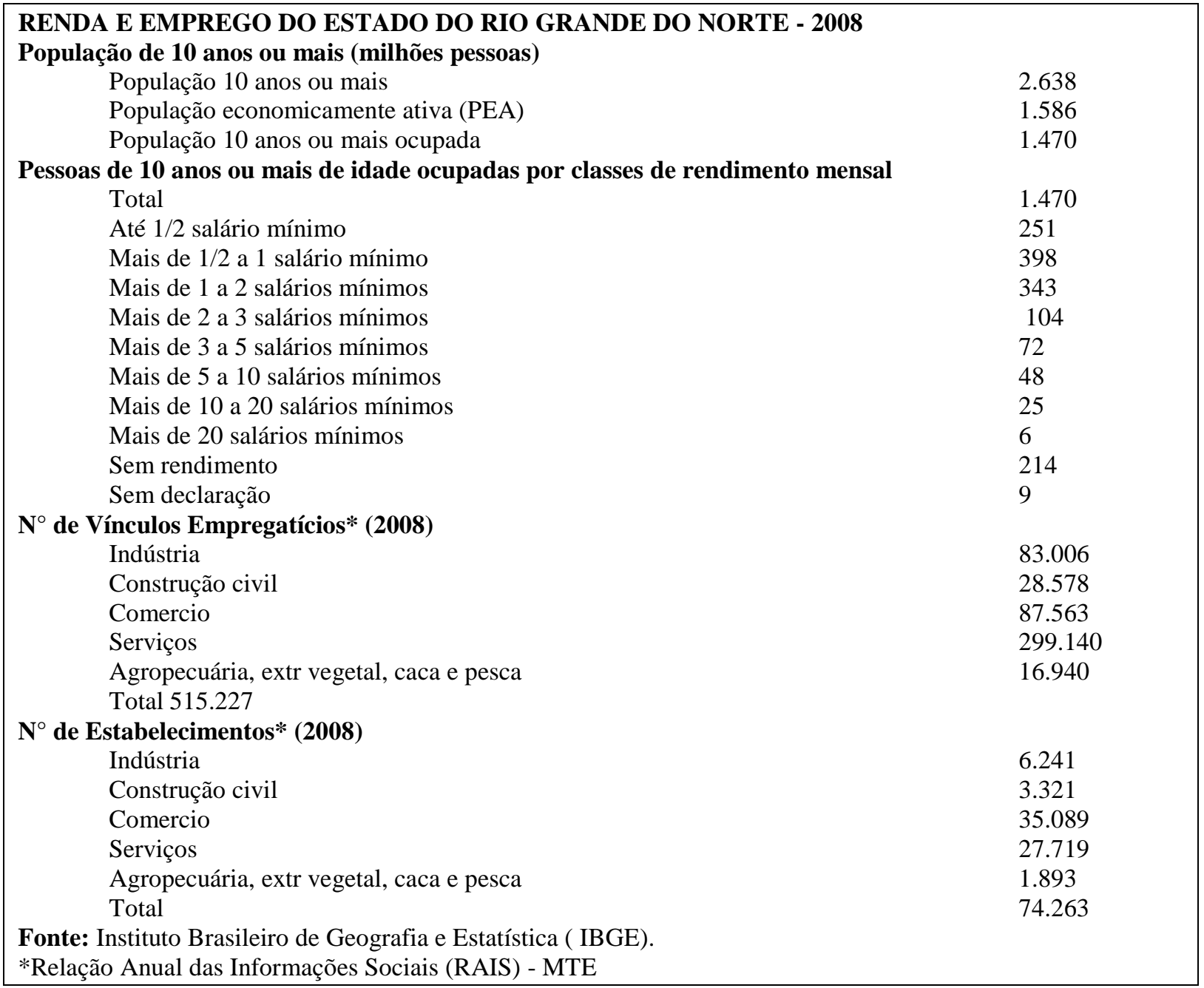

\section{Quadro 10}

\section{INFORMAÇÕES AGROPECUÁRIAS DO ESTADO DO RIO GRANDE DO NORTE - 2006}

Número de estabelecimentos agropecuários

Área dos estabelecimentos agropecuários (hectare) 
Área de lavouras permanentes (hectare)

461.419

Número de estabelecimentos com lavouras temporárias

59.935

Área de lavouras temporárias (hectare)

Número de estabelecimentos com pastagens naturais

Área de pastagens naturais (hectare)

1.333 .585

Número de estabelecimentos agropecuários com tratores

2.788

Número de tratores existentes nos estabelecimentos agropecuários

3.584

Fonte: Censo Agropecuário 2006 - Resultados Preliminares.

\section{Quadro 11}

\section{FINANÇAS PÚBLICAS DO RIO GRANDE DO NORTE - 2007}

Receitas orçamentárias realizadas

Receitas orçamentárias realizadas - Correntes

Receitas orçamentárias realizadas - Tributárias

Receitas orçamentárias realizadas - IPTU

Receitas orçamentárias realizadas - Imposto Sobre Serviços - ISS

Receitas orçamentárias realizadas - Imposto sobre Transmissão-Intervivos - ITBI

Receitas orçamentárias realizadas - Taxas

Receitas orçamentárias realizadas - Contribuição

Receitas orçamentárias realizadas - Patrimonial

Receitas orçamentárias realizadas - Transferências Correntes

Receitas orçamentárias realizadas - Transferência Intergovernamental da União

Receitas orçamentárias realizadas - Transferência Intergovernamental do Estado

Receitas orçamentárias realizadas - Dívida Ativa

Receitas orçamentárias realizadas - Outras Receitas Correntes

Receitas orçamentárias realizadas - Capital

Receitas orçamentárias realizadas - Transferência de Capital

Despesas orçamentárias realizadas

Despesas orçamentárias realizadas - Correntes

Despesas orçamentárias realizadas - Outras Despesas Correntes

Despesas orçamentárias realizadas - Capital

Despesas orçamentárias realizadas - Investimentos

Despesas orçamentárias realizadas - Pessoal e Encargos Sociais

Despesas orçamentárias realizadas - Obras e Instalações

Despesas orçamentárias realizadas - Superavit ou Déficit

Valor do Fundo de Participação dos Municípios - FPM

Valor do Imposto Territorial Rural - ITR

$3.016 .192 .885,89$

Reais

3.146.751.618,32 Reais

$341.768 .160,66$

$45.241 .096,15$

$190.056 .431,00$

Reais

$33.933 .864,90$

Reais

$35.960 .717,71$

65.455.373,55

27.666.015,97

2.622.391.486,23

1.529.165.050,16

Reais

Reais

Reais

Reais

Reais

Reais

$552.211 .450,00$

20.718.574,58

Reais

Reais

68.802.612,41

Reais

$90.681 .221,79$

Reais

$76.301 .409,50$

$3.042 .685 .752,73$

Reais

Reais

2.645.759.927,99

Reais

$1.181 .781 .461,52$

396.925.824,63 Reais

355.070.531,82 Reais

1.455.607.022,54 Reais

282.023.314,61 Reais

$-26.492 .866,79 \quad$ Reais

978.015.356,06 Reais

$735.768,26$

Valor do Imp. sobre Oper. Financeiras - IOF - OURO - repassado aos Municípios 21.079,08

Fonte: Ministério da Fazenda, Secretaria do Tesouro Nacional, Registros Administrativos 2007.

Em relação aos dados apresentados nos Quadros 4 a 11, vale comentar algumas informações cujo conteúdo guarda pertinência ao objeto da pesquisa, sendo recomendável para tanto expor a análise divulgada, por meio eletrônico, pelo escritório local do IBGE (2010).

O PIB do RN estimado em 2007 foi de R 22.926 milhões (0,9 do PIB) superior ao de 2006, que foi de R $\$ 20.555$ milhões. Foi o $18^{\circ}$ maior PIB dentre os estados. Na série (20022007) apresentou o $25^{\circ}$ maior crescimento em volume (17,4\%), perdendo posição em relação a $2006=20^{\circ}$ lugar. O PIB per capita ficou em $\mathrm{R} \$ 7.607,01$ contra $\mathrm{R} \$ 6.753,04$ em 2006, garantindo a mesma posição do ano anterior no ranking brasileiro (20 posição). 
Os cinco maiores municípios no que se refere à participação do PIB no RN, em 2006, foram: Natal (35,0\%), Mossoró (11,7\%), Parnamirim (6,1\%), Guamaré (3,9\%) e São Gonçalo do Amarante (2,7\%), juntos representavam (59,3\%) do PIB do RN, mostrando a concentração da geração interna da renda, pois, os cinco municípios respondiam juntos por mais da metade da economia estadual. A pesquisa mostra a espacialização da geografia da produção no $\mathrm{RN}$, bem como a participação relativa dos 5 municípios com $(42,2 \%)$ da população do Estado.

Em relação às atividades econômicas do RN, em 2007, a agropecuária com volume de $(-8 \%)$ em 2007, perdeu $(1,3 \%)$ na participação no valor adicionado total do Estado $(6,4 \%$ em 2006 e 5,1\% em 2007). A produção vegetal contribuiu com um volume de $(-9,8 \%)$, influenciada, sobretudo pelo volume de $(-15,5 \%)$ da atividade de cultivo de outros produtos da lavoura temporária, tais como: queda de $(-6,1 \%)$ na produção de melão e $(-34,7 \%)$ na produção de feijão. Alem disso, houve redução $(-3,7 \%)$ na atividade de cultivo de outros produtos da lavoura permanente, queda de $(-5,8 \%)$ na produção de banana e de $(-15,6)$ na produção de castanha de caju. Obteve crescimento positivo $(+7,2 \%)$ a atividade de cultivo da cana-de-açúcar (aumento de 13,1\% na produção de cana). Os cinco municípios que mais se destacaram na atividade agropecuária foram: Mossoró (melão); Touros (abacaxi); Baraúna (melão); Ceará - Mirim (cana-de-açúcar) e São José de Mipibu (cana-de-açúcar).

A produção animal que participava com $(60,5 \%)$ do setor agropecuário em 2007 , apresentou volume (-6,5\%), bastante influenciado pela redução de $(5,3 \%)$ em volume de bovinocultura (redução de $(1,7 \%)$ do efetivo de bovinos) e, na avicultura $(10,1 \%)$ das aves produzidas

O setor industrial apresentou taxa de volume em torno de 0\% em 2007. A indústria de transformação contribuiu com um volume de $(+3,2 \%)$ e a construção civil com $(+6,5 \%)$. Em sentido contrário, encontrava-se a atividade industrial extrativa mineral, por ter obtido taxa de volume de $(-5 \%)$, influenciada pela redução em volume de $(-5,6 \%)$ da atividade de extração de petróleo e gás natural, tivemos, também, os serviços industriais de utilidade pública com (3,5\%). Os cinco municípios que mais se destacaram na indústria foram: Mossoró (extrativa); Natal (construção civil); Areia Branca (extrativa); Macau (extrativa); Parnamirim (transformação). 
O setor de serviços cresceu 4,3\% em termos reais em 2007. O setor serviços, excetuando-se a administração, saúde e educação pública que participava com (27,5\%) na economia estadual, tem no comércio sua principal atividade, responsável por $(14,2 \%)$ de todo o valor adicionado do estado. Neste segmento destacou-se o Comércio Atacadista e o Comércio Varejista, sobressaindo-se, o de Veículos e o de Hipermercados e Supermercados. Os 5 principais municípios em relação a participação na atividade de serviços foram: Natal, Mossoró, Parnamirim, Guamaré e Caicó.

\section{Balanço geral da Previdência Social no Rio Grande do Norte}

\subsection{Quantidade de benefícios emitidos}

Seguindo a conceituação adotada pelo MPS, compreendem-se por Benefícios as prestações pecuniárias pagas pela Previdência Social aos segurados ou aos seus dependentes, de forma a atender a cobertura dos eventos de doença, acidentes do trabalho, invalidez, morte ou idade avançada, bem como tempo de contribuição e o trabalho sujeito a condições especiais; a proteção à maternidade; salário-família e auxílio-reclusão; e as prestações assistenciais pagas às pessoas idosas ou portadoras de deficiência.

A quantidade de benefícios emitidos, por sua vez, corresponde ao número de créditos emitidos pelo INSS para pagamento de benefícios do Regime Geral de Previdência Social, Encargos Previdenciários da União e Amparos Assistenciais previstos na Lei Orgânica da Assistência Social, classificados pelo município do órgão pagador.

Na média nacional, o percentual de beneficiários rurais da Previdência Social tem se mostrado decrescente em relação à clientela urbana, fenômeno que se percebe também no RN, mas, diversamente do estado potiguar, no Brasil, a clientela rural em números absolutos é significativamente inferior à clientela urbana, conforme ilustra o Gráfico 9. 


\section{Gráfico 10}

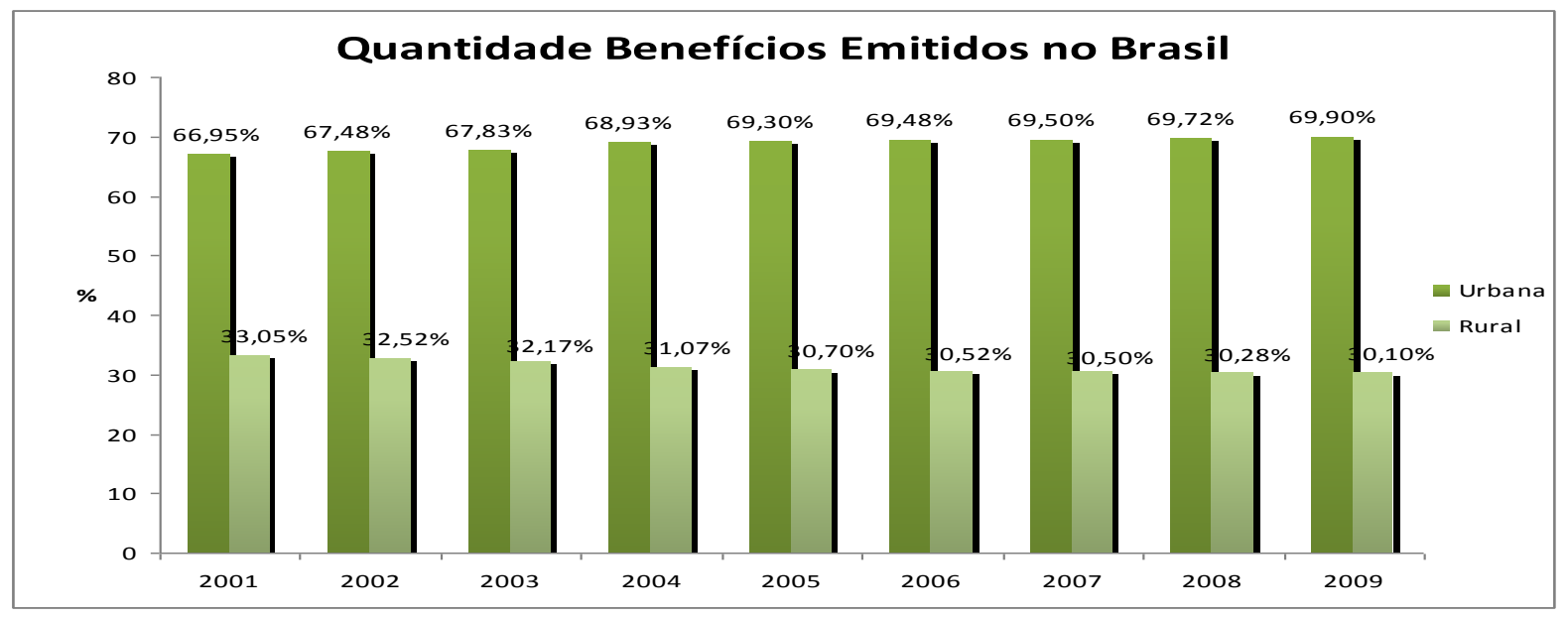

Fonte: Síntese/Dataprev. Elaboração: do autor

Em 2009, apenas 8 dos 27 estados da federação, todos da Região Norte ou Nordeste, apresentaram a clientela rural superior à urbana, nos termo do Quadro 12 abaixo.

Quadro 12

\begin{tabular}{|c|c|c|c|}
\hline \multirow[t]{2}{*}{ UNIDADE DA FEDERAÇÃO } & \multicolumn{3}{|c|}{$\begin{array}{c}\text { QUANTIDADE DE BENEFÍCIOS EMITIDOS PELO INSS } \\
\text { NO MÊS DE DEZEMBRO/2009 }\end{array}$} \\
\hline & Total & Urbano & Rural \\
\hline ACRE & 67.552 & 36.267 & 31.285 \\
\hline ALAGOAS & 409.364 & 255.591 & 153.773 \\
\hline AMAPÁ & 38.281 & 25.478 & 12.803 \\
\hline AMAZONAS & 229.779 & 145.175 & 84.604 \\
\hline $\begin{array}{l}\text { BAHIA } \\
\text { CEARÁ }\end{array}$ & $\begin{array}{l}1.929 .498 \\
1.182 .213\end{array}$ & $\begin{array}{l}943.361 \\
513.294\end{array}$ & $\begin{array}{r}986.137 \\
668.919\end{array}$ \\
\hline DISTRITO FEDERAL & 221.245 & 205.842 & 15.403 \\
\hline ESPIRITO SANTO & 483.503 & 324.635 & 158.868 \\
\hline GOIÁS & 625.462 & 412.203 & 213.259 \\
\hline MARANHÃO & 828.620 & 272.163 & 556.457 \\
\hline MATO GROSSO & 283.284 & 167.735 & 115.549 \\
\hline MATO G. DO SUL & 276.022 & 186.763 & 89.259 \\
\hline MINAS GERAIS & 3.087 .580 & 2.164 .311 & 923.269 \\
\hline PARÁ & 645.788 & 325.216 & 320.572 \\
\hline PARAÍBA & $\mathbf{5 9 7 . 7 0 5}$ & 265.264 & 332.441 \\
\hline PARANÁ & 1.560 .515 & 979.215 & 581.300 \\
\hline PERNAMBUCO & 1.271 .087 & 732.634 & 538.453 \\
\hline PIAUÍ & 455.064 & 152.034 & 303.030 \\
\hline RIO DE JANEIRO & 2.475 .764 & 2.400 .985 & 74.779 \\
\hline RIO G. DO NORTE & 462.361 & 221.139 & 241.222 \\
\hline RIO G. DO SUL & 2.144 .537 & 1.541 .457 & 603.080 \\
\hline RONDÔNIA & 166.434 & 66.510 & 99.924 \\
\hline RORAIMA & 29.637 & 14.378 & 15.259 \\
\hline SANTA CATARINA & 1.063 .411 & 765.132 & 298.279 \\
\hline SÃO PAULO & 6.113 .725 & 5.594 .963 & 518.762 \\
\hline
\end{tabular}




\begin{tabular}{|c|c|c|c|} 
SERGIPE & 256.236 & 138.971 & 117.265 \\
TOCANTINS & $\mathbf{1 4 4 . 7 0 6}$ & $\mathbf{5 5 . 9 8 2}$ & $\mathbf{8 8 . 7 2 4}$ \\
TOTAL & $\mathbf{2 7 . 0 4 9 . 3 7 3}$ & $\mathbf{1 8 . 9 0 6 . 6 9 8}$ & $\mathbf{8 . 1 4 2 . 6 7 5}$ \\
\hline
\end{tabular}

Fonte: SINTESE/DATAPREV

A evolução do número de benefícios emitidos no RN, no período de 2001 a 2009, aponta um significativo crescimento do número total de beneficiários, rurais e urbanos, no Rio Grande do Norte, registrando-se um crescimento absoluto de 182.456 mil pessoas.

O Quadro 13 e o Gráfico 11 ao tempo em que apresentam uma superioridade do número absoluto de beneficiários rurais em relação aos beneficiários urbanos, indicam uma permanente diminuição percentual dessa superioridade numérica, a ponto de ser possível cogitar a reversão desta situação em médio prazo, a depender de o estado potiguar melhorar a formalização do emprego em suas áreas urbanas e rurais.

Em 1993, o percentual da clientela rural beneficiária do RGPS, no RN, era de 57,09\% da população de beneficiários, caindo, no ano de 2009, para 52,17\%. No Anexo I segue o histórico de quantidade de benefícios emitidos em cada um dos 167 municípios do RN no período de 2000-2009.

Quadro 13

\begin{tabular}{|l|c|c|c|c|c|}
\hline \multicolumn{6}{|l|}{ Quantidade/Percentual de benefícios emitidos pelo INSS no RN, por clientela } \\
\hline Ano & Urbana & \% & Rural & \% & Total \\
\hline $\mathbf{1 9 9 3}$ & 120.112 & 42,91 & 159.793 & 57,09 & 279.905 \\
\hline $\mathbf{1 9 9 4}$ & 129.641 & 43,45 & 168.718 & 56,55 & 298.359 \\
\hline $\mathbf{1 9 9 5}$ & 131.135 & 43,82 & 168.153 & 56,18 & 299.288 \\
\hline $\mathbf{1 9 9 6}$ & 146.317 & 45,89 & 172.518 & 54,11 & 318.835 \\
\hline $\mathbf{1 9 9 7}$ & 153.749 & 46,63 & 175.994 & 53,37 & 329.743 \\
\hline $\mathbf{1 9 9 8}$ & 159.880 & 46,83 & 181.497 & 53,17 & 341.377 \\
\hline $\mathbf{1 9 9 9}$ & 161.138 & 46,72 & 183.749 & 53,28 & 344.887 \\
\hline $\mathbf{2 0 0 0}$ & 164.624 & 46,77 & 187.399 & 53,23 & 352.023 \\
\hline $\mathbf{2 0 0 1}$ & 166.666 & 46,88 & 188.874 & 53,12 & 355.540 \\
\hline $\mathbf{2 0 0 2}$ & 174.551 & 46,85 & 197.987 & 53,15 & 372.538 \\
\hline $\mathbf{2 0 0 3}$ & 179.357 & 46,66 & 205.044 & 53,34 & 384.401 \\
\hline $\mathbf{2 0 0 4}$ & 190.652 & 47,09 & 214.206 & 52,91 & 404.858 \\
\hline $\mathbf{2 0 0 5}$ & 197.521 & 47,12 & 221.651 & 52,88 & 419.172 \\
\hline $\mathbf{2 0 0 6}$ & 203.296 & 47,37 & 225.832 & 52,63 & 429.128 \\
\hline $\mathbf{2 0 0 7}$ & 206.951 & 47,4 & 229.692 & 52,6 & 436.643 \\
\hline $\mathbf{2 0 0 8}$ & 212.567 & 47,49 & 235.029 & 52,51 & 447.596 \\
\hline $\mathbf{2 0 0 9}$ & 221.139 & 47,83 & 241.222 & 52,17 & 462.361 \\
\hline
\end{tabular}

Fonte: de 2001 a 2008, AEPS, vários anos. Infologo. Em 2009, Síntese/Dataprev

Elaboração: do autor 


\section{Gráfico 11}

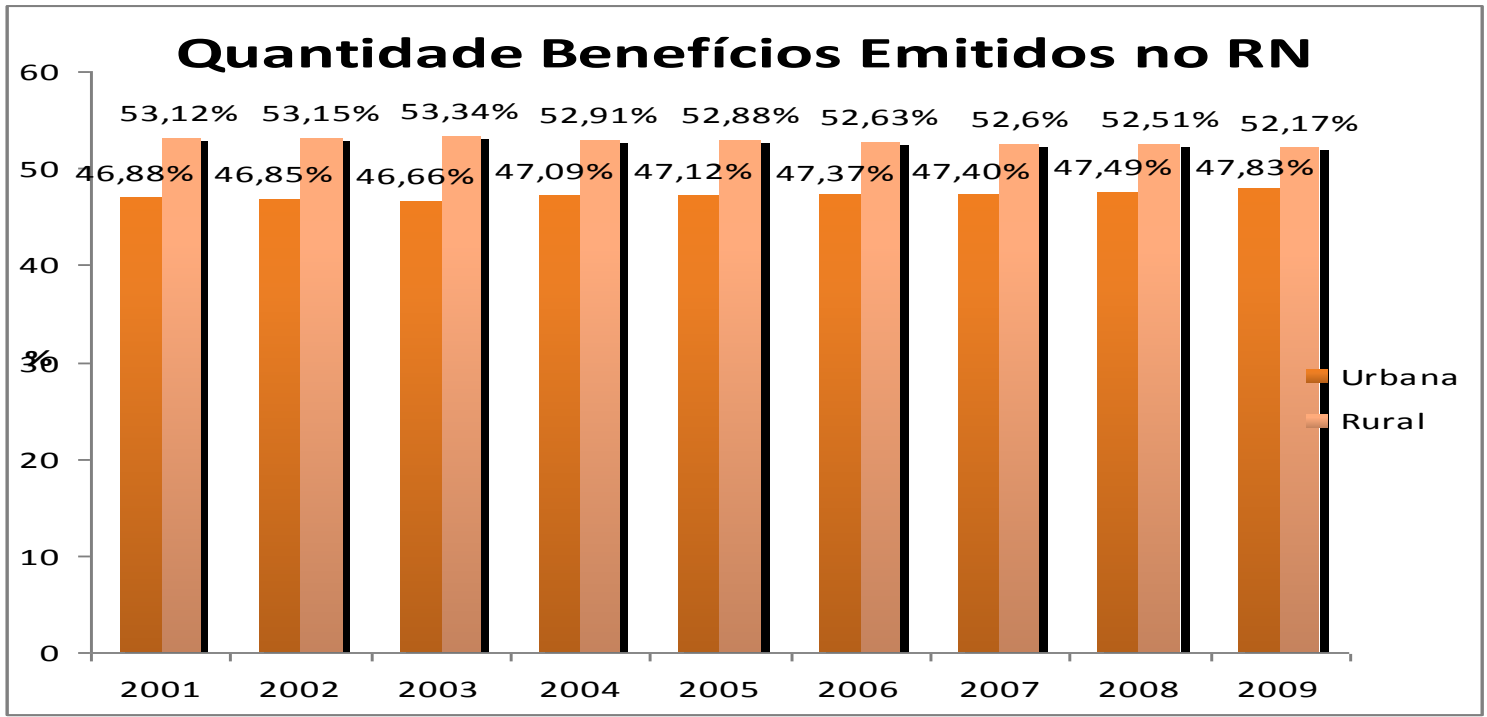

Fonte: Síntese/Dataprev. Elaboração: do autor

A diminuição da clientela previdenciária rural no RN corrobora a tendência observada nacionalmente, onde se verificou a diminuição do percentual de segurados especiais de 10,5\%, em 2001, para 8,6\%, em 2008, da PEA atingida pela cobertura previdenciária (IPEA, 2009a), esta tendência de queda está relacionada com a redução dos desocupados (pessoas sem emprego formal), tanto nas áreas urbanas quanto rurais, ao longo desta década.

Vê-se na Tabela 9 que, no Brasil, os desocupados caíram de 9,8\% da PEA em 2003 para 7,3\% em 2008. Com relação ao percentual de contribuintes, também se observa sua elevação nos meios urbano e rural, a qual tem sido contínua desde 2002. O corolário disto é que a participação dos não contribuintes na PEA tem-se reduzido ao longo dos anos. Vale ressaltar que em 2008 os não contribuintes do meio rural ainda representavam 71,6\% da PEA. Contudo, grande parte destes cidadãos enquadra-se como segurado especial da previdência social, estando, portanto, coberta.

Tabela 9

Distribuição da PEA segundo o domicílio e status de ocupação em anos selecionados

\begin{tabular}{|c|c|c|c|c|c|c|c|c|c|}
\hline $\begin{array}{c}(\text { Em \%) } \\
\text { Domicílio }\end{array}$ & Status & 2001 & 2002 & 2003 & 2004 & 2005 & 2006 & 2007 & 2008 \\
\hline \multirow{5}{*}{$\begin{array}{c}\text { Urbano } \\
\text { metropolitano }\end{array}$} & Contribuinte & 53,0 & 51,8 & 52,7 & 53,1 & 53,4 & 55,0 & 56,4 & 58,2 \\
\hline & $\begin{array}{c}\text { Não } \\
\text { contribuinte }\end{array}$ & 34,3 & 35,3 & 33,6 & 33,7 & 33,6 & 33,2 & 32,6 & 32,4 \\
\hline & Desocupado & 12,7 & 13,0 & 13,8 & 13,1 & 13,0 & 11,8 & 10,9 & 9,4 \\
\hline & Total & 100,0 & 100,0 & 100,0 & 100,0 & 100,0 & 100,0 & 100,0 & 100,0 \\
\hline & Contingente & 24.829 & 25.834 & 25.998 & 26.924 & 27.857 & 28.198 & 28.764 & 29.263 \\
\hline
\end{tabular}




\begin{tabular}{|c|c|c|c|c|c|c|c|c|c|}
\hline & total $^{1}$ & & & & & & & & \\
\hline \multirow{5}{*}{$\begin{array}{l}\text { Urbano não } \\
\text { metropolitano }\end{array}$} & Contribuinte & 46,7 & 46,4 & 46,8 & 47,9 & 48,8 & 50,3 & 52,2 & 53,9 \\
\hline & $\begin{array}{c}\text { Não } \\
\text { contribuinte }\end{array}$ & 43,8 & 44,7 & 43,6 & 43,5 & 41,9 & 41,5 & 39,7 & 38,9 \\
\hline & Desocupado & 9,5 & 8,9 & 9,6 & 8,5 & 9,2 & 8,2 & 8,1 & 7,2 \\
\hline & Total & 100,0 & 100,0 & 100,0 & 100,0 & 100,0 & 100,0 & 100,0 & 100,0 \\
\hline & $\begin{array}{c}\text { Contingente } \\
\text { total }^{1}\end{array}$ & 40.764 & 42.338 & 43.938 & 45.242 & 46.475 & 47.623 & 48.342 & 49.881 \\
\hline \multirow[t]{5}{*}{ Rural } & Contribuinte & 17,6 & 17,3 & 18,3 & 19,3 & 20,2 & 21,9 & 23,7 & 25,7 \\
\hline & $\begin{array}{c}\text { Não } \\
\text { contribuinte }\end{array}$ & 79,7 & 80,1 & 79,0 & 77,7 & 76,8 & 74,8 & 73,3 & 71,6 \\
\hline & Desocupado & 2,7 & 2,7 & 2,7 & 2,9 & 3,1 & 3,2 & 3,0 & 2,7 \\
\hline & Total & 100,0 & 100,0 & 100,0 & 100,0 & 100,0 & 100,0 & 100,0 & 100,0 \\
\hline & $\begin{array}{c}\text { Contingente } \\
\text { total }\end{array}$ & 12.593 & 12.907 & 13.096 & 13.246 & 13.880 & 13.556 & 13.557 & 13.347 \\
\hline \multirow[t]{5}{*}{ Brasil } & Contribuinte & 44,0 & 43,5 & 44,1 & 45,1 & 45,8 & 47,5 & 49,3 & 51,2 \\
\hline & $\begin{array}{c}\text { Não } \\
\text { contribuinte }\end{array}$ & 46,6 & 47,3 & 46,0 & 45,7 & 44,8 & 43,9 & 42,5 & 41,6 \\
\hline & Desocupado & 9,4 & 9,2 & 9,8 & 9,1 & 9,5 & 8,6 & 8,3 & 7,3 \\
\hline & Total & 100,0 & 100,0 & 100,0 & 100,0 & 100,0 & 100,0 & 100,0 & 100,0 \\
\hline & $\begin{array}{c}\text { Total da } \\
\text { PEA }^{1}\end{array}$ & 78.185 & 81.078 & 83.032 & 85.412 & 88.211 & 89.377 & 90.662 & 92.491 \\
\hline
\end{tabular}

Fonte: Microdados PNADs. Elaboração: IPEA, 2009a, p. 26.

\subsection{Valor dos Benefícios Emitidos no $\mathbf{R N}$}

O Valor dos benefícios emitidos corresponde ao valor líquido (diferença entre valor bruto e descontos) dos créditos emitidos pelo Instituto Nacional de Previdência Social - INSS para pagamento de benefícios do Regime Geral de Previdência Social, Encargos Previdenciários da União e Amparos Assistenciais previstos na Lei Orgânica da Assistência Social, classificados pelo município do órgão pagador.

Verifica-se que dos 167 municípios do RN apenas em 22 deles os valores transferidos pela Previdência Social à clientela urbana superam os valores transferidos à clientela rural. 
Segue no Anexo I o histórico do valor anual dos benefícios emitidos no período de 2000 a 2009 em cada um dos 167 municípios do RN.

A evolução dos valores anuais dos benefícios emitidos no RN, no período de 2000 a 2009, revela que, apesar da superioridade do número de beneficiários rurais em relação aos beneficiários urbanos, a quantidade monetária resultante do pagamento dos benefícios urbanos prevalece sobre o valor somado dos benefícios rurais.

Este fenômeno é justificado pelo valor médio mais elevado dos benefícios pagos à clientela urbana.

Tabela 10

\begin{tabular}{|c|c|c|c|}
\hline \multicolumn{4}{|c|}{ VALOR ANUAL DOS BENEFÍCIOS EMITIDOS NO RN - POR CLIENTELA - R\$ } \\
\hline & RURAL & URBANA & TOTAL \\
\hline $\mathbf{2 0 0 1}$ & $420.644 .755,17$ & $570.891 .124,08$ & $991.535 .879,25$ \\
\hline $\mathbf{2 0 0 2}$ & $486.891 .725,64$ & $657.422 .614,89$ & $1.144 .314 .340,53$ \\
\hline $\mathbf{2 0 0 3}$ & $597.603 .828,00$ & $800.330 .178,00$ & $1.397 .934 .006,00$ \\
\hline $\mathbf{2 0 0 4}$ & $681.498 .850,00$ & $928.349 .687,00$ & $1.609 .848 .537,00$ \\
\hline $\mathbf{2 0 0 5}$ & $784.134 .496,00$ & $1.039 .816 .150,00$ & $1.823 .950 .646,00$ \\
\hline $\mathbf{2 0 0 6}$ & $916.691 .491,46$ & $1.175 .876 .871,32$ & $2.092 .568 .362,78$ \\
\hline $\mathbf{2 0 0 7}$ & $1.005 .748 .039,80$ & $1.284 .500 .077,74$ & $2.290 .248 .117,54$ \\
\hline $\mathbf{2 0 0 8}$ & $1.111 .187 .516,19$ & $1.405 .842 .868,61$ & $2.517 .030 .384,80$ \\
\hline $\mathbf{2 0 0 9}$ & 1.281 .692 .861 & 1.604 .696 .342 & 2.886 .389 .203 \\
\hline
\end{tabular}

Fonte: de 2001 a 2008, AEPS, vários anos. Infologo. Em 2009, Síntese/Dataprev

Elaboração: do autor

De qualquer sorte, analisando a evolução percentual do valor anual dos benefícios emitidos no RN, Gráfico 12, constata-se uma aproximação entre a expressão monetária dos benefícios pagos às duas clientelas. Veja-se que, de 2001 a 2009, a diferença percentual entre os valores anuais dos benefícios emitidos aos urbanos e rurais caiu de 15,16\% para 11,2\%, não obstante tenha diminuído a superioridade numérica da clientela rural sobre a urbana, como visto no item anterior. Na média nacional esta diferença é de aproximadamente $80 \%$ (Gráfico 13). 


\section{Gráfico 12}

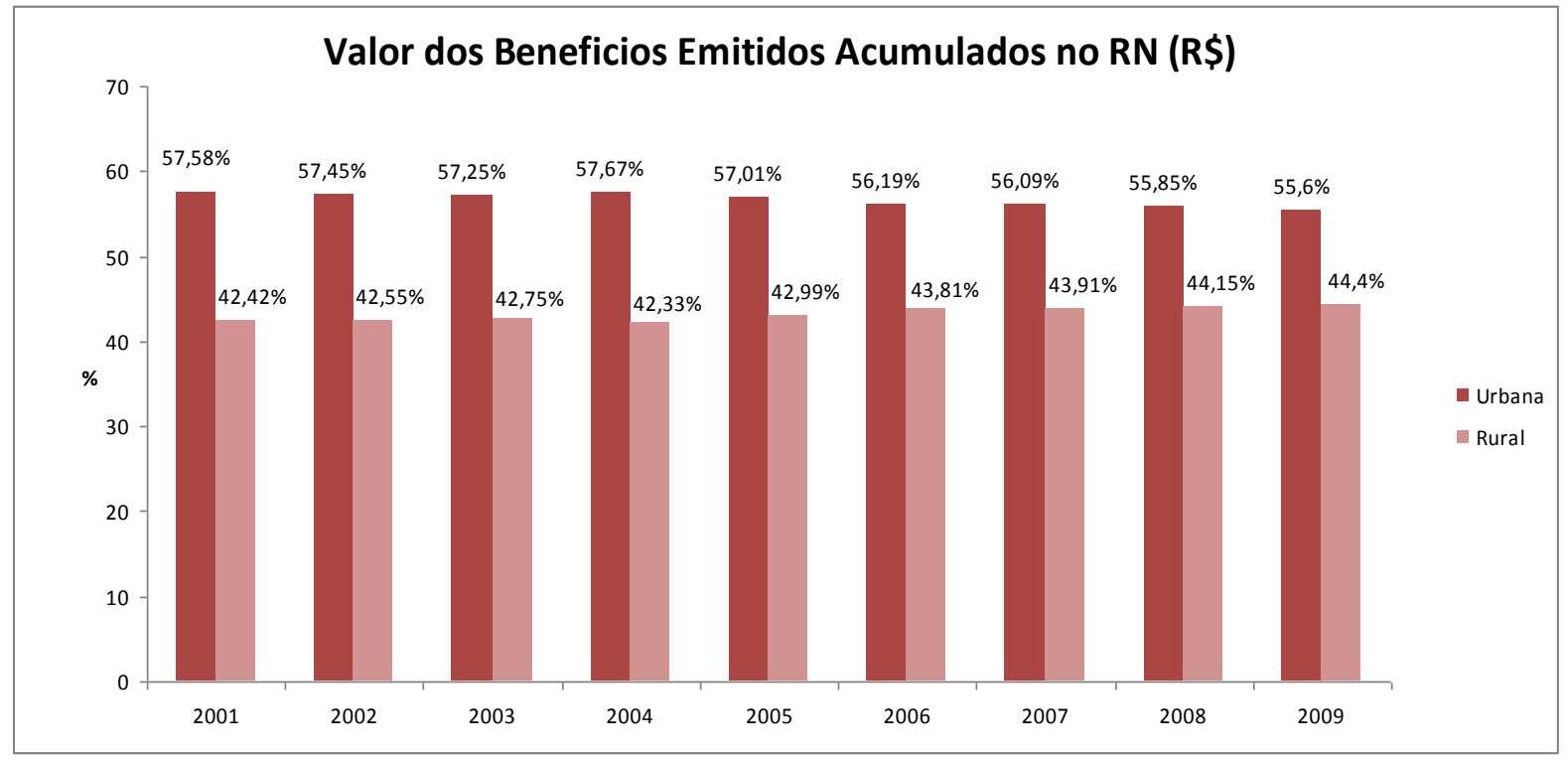

Fonte: SINTESE/DATAPREV.

Elaboração: do autor

Gráfico 13

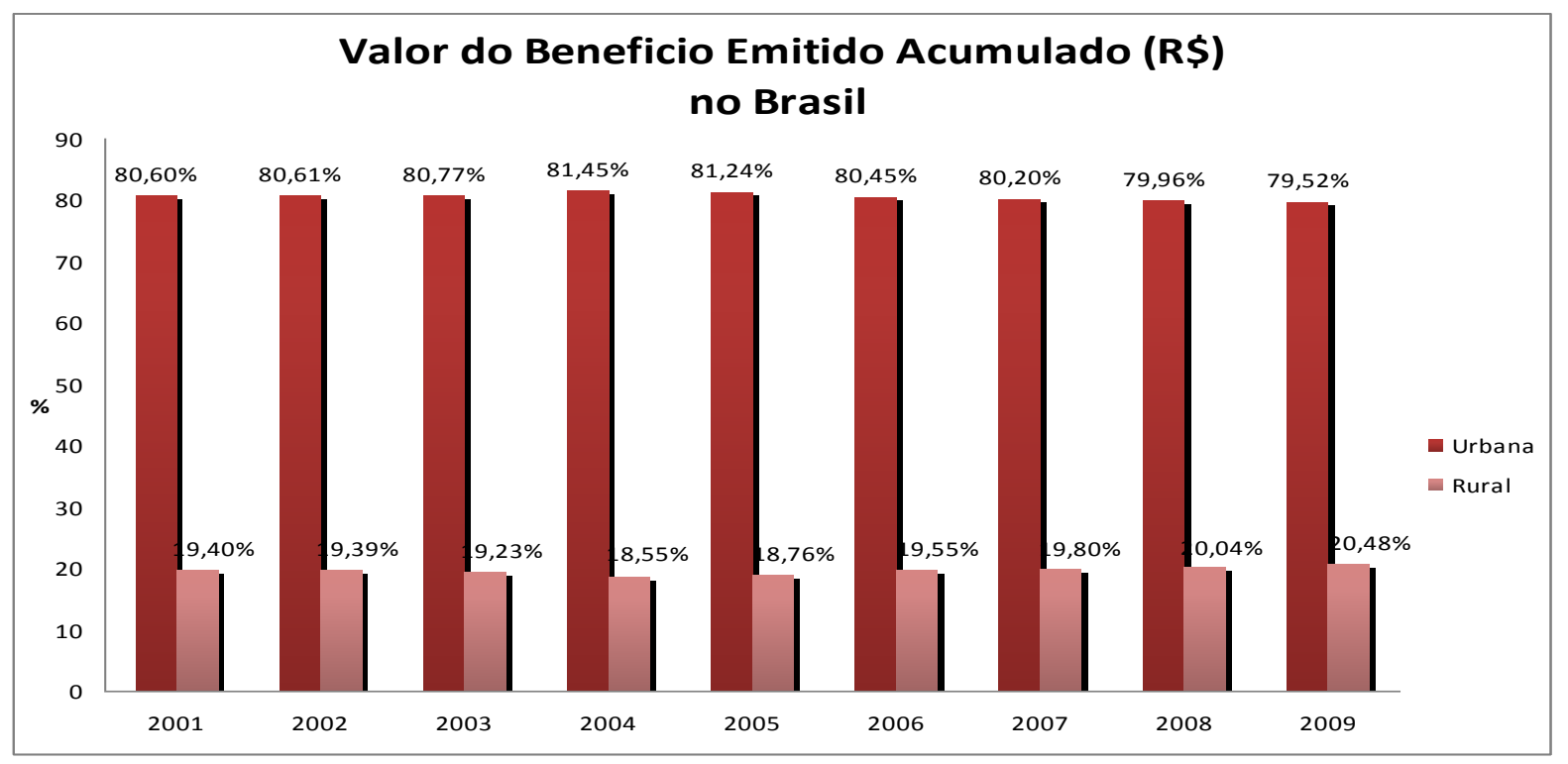

Fonte: AEPS, vários anos. Infologo.

Elaboração: do autor

Este fenômeno é justificado pelos consecutivos reajustes do salário mínimo em percentuais significativamente superiores à inflação, já que aproximadamente $99 \%$ dos beneficiários rurais percebem até um salário mínimo mensal, enquanto que os beneficiários urbanos, em considerável proporção com proventos superiores ao mínimo legal, têm obtido reajustes mais módicos. 


\section{Gráfico 14}

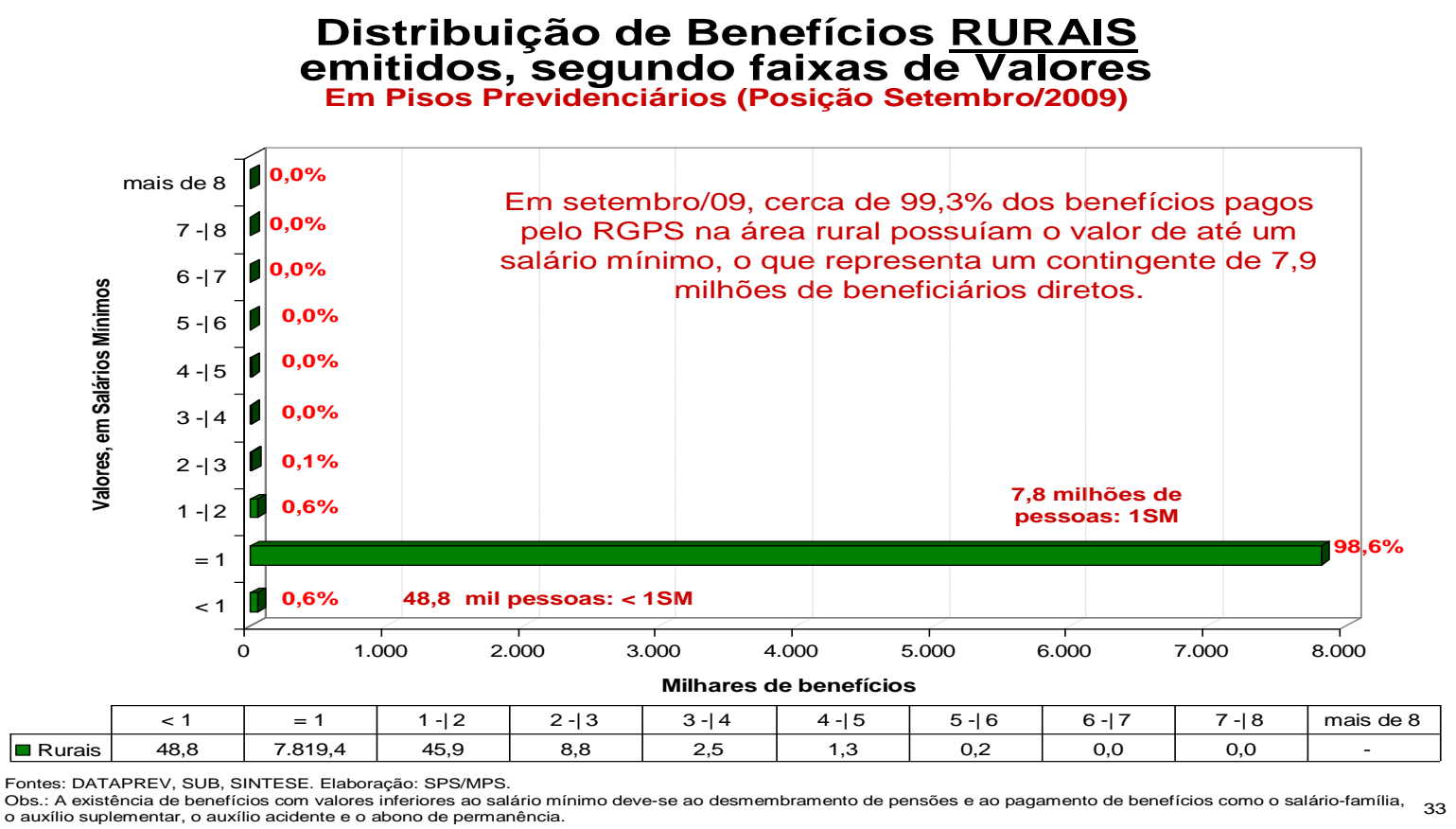

A política de reajuste dos benefícios da Previdência Social com valor superior ao salário mínimo é definida na Constituição Federal de 1988, com o intuito de garantir o poder de compra dos beneficiários (valor real), conforme o disposto no $\S 4^{\circ}$ do art. 201. Importante destacar que a própria Constituição Federal veda a vinculação de qualquer grandeza da economia ao salário mínimo (Art. $7^{\circ}$, Inciso IV). Com esta vedação, os constituintes objetivaram propiciar a concessão de aumentos reais para o salário mínimo, sem que estes fossem anulados pelo reajustamento automático dos preços e, ao mesmo tempo, para não causar impacto nas contas da Previdência Social e dos governos municipais e estaduais.

Segundo Ansiliero e Costanzi (2009), nos anos de 2003 a 2009, o reajuste do salário mínimo sempre ficou acima da inflação medida pelo INPC, com ganho real acumulado de $44,97 \%$, o que significaria a alternativa política de, por intermédio do reajuste do salário mínimo acima da inflação, promover melhor distribuição de renda por meio do sistema previdenciário e assistencial, uma vez que, no RGPS, em 2008, 17,8 milhões de pessoas receberam benefícios no valor de 1 salário mínimo, ou seja, cerca de 2 em cada 3 beneficiários. 
O gráfico abaixo, extraído do trabalho de Ansiliero e Costanzi (2009, p. 184), restrito ao período 2002-2009, demonstra que há um descolamento entre o reajuste dado ao salário mínimo e as curvas dos índices de inflação, intensificado no período 2005-2009.

Gráfico 15

Evolução do Reajuste do Salário Mínimo, INPC, IPCA e IPC-3i 2002-2009, sendo $2002=100$

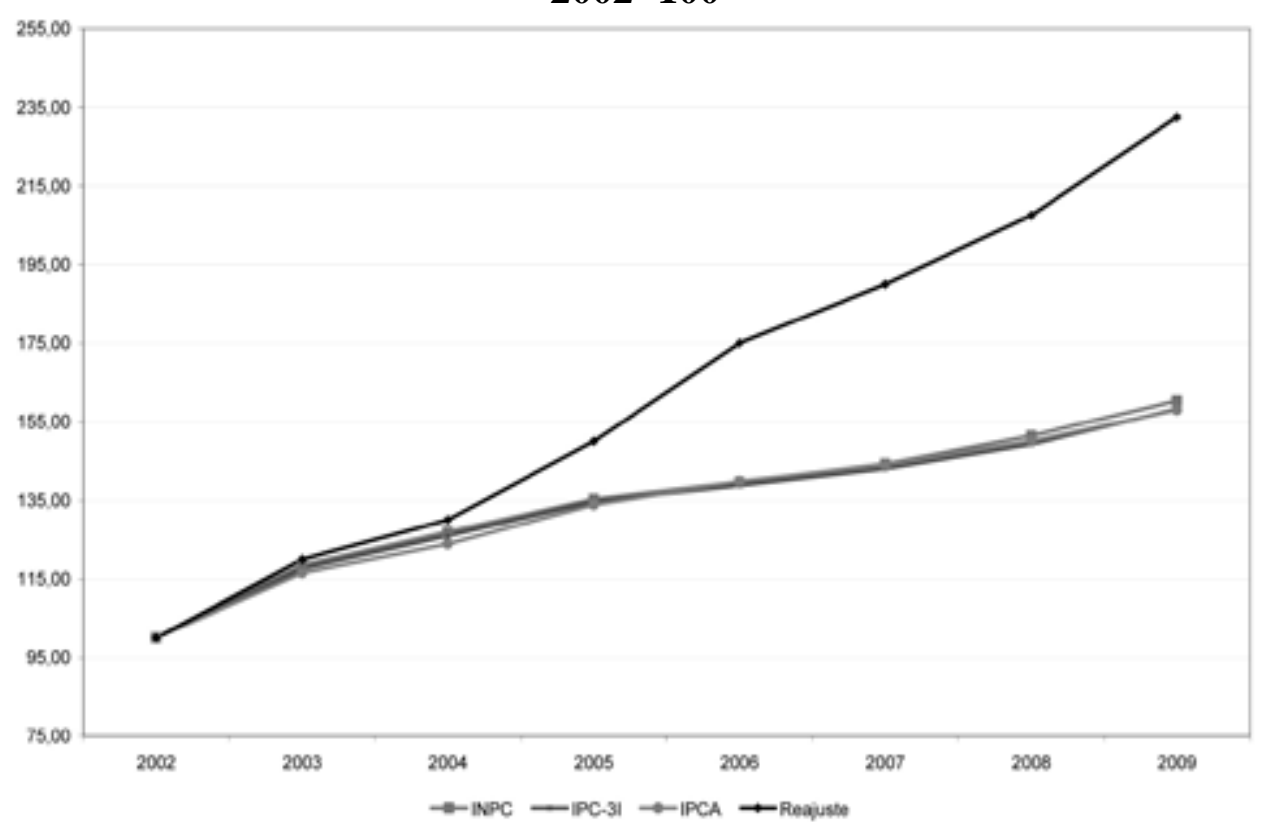

Fonte: IBGE; FGV - Elaboração: SPS/MPS.

No mesmo período de 2003 a 2009, o ganho real em relação ao INPC dos benefícios com valor superior ao piso previdenciário foi de apenas $0,89 \%$, apresentando índices negativos nos anos de 2003. 2004 e 2005; e neutralidade no ano de 2007.

O Gráfico 16, também extraído da pesquisa de Ansiliero e Costanzi (2009, p. 187), revela que, embora minguados, no período de 2003 a 2009, verificou-se igualmente ganhos reais aos beneficiários com ganhos além de um salário mínimo perante os índices inflacionários. Destacam os autores que muitos benefícios tiveram reajustes entre aquele prevalecente para o salário mínimo e os demais benefícios pelo chamado efeito arrasto do salário mínimo, ou seja, para aqueles benefícios que embora fossem superiores ao piso previdenciário antes de um determinado reajuste, estavam entre o salário mínimo anterior e o novo piso. 


\section{Gráfico 16 \\ Evolução do Reajuste dos Benefícios Acima de 1 SM e INPC, IPCA e IPC-3i 2002-2009, sendo $2002=100$}

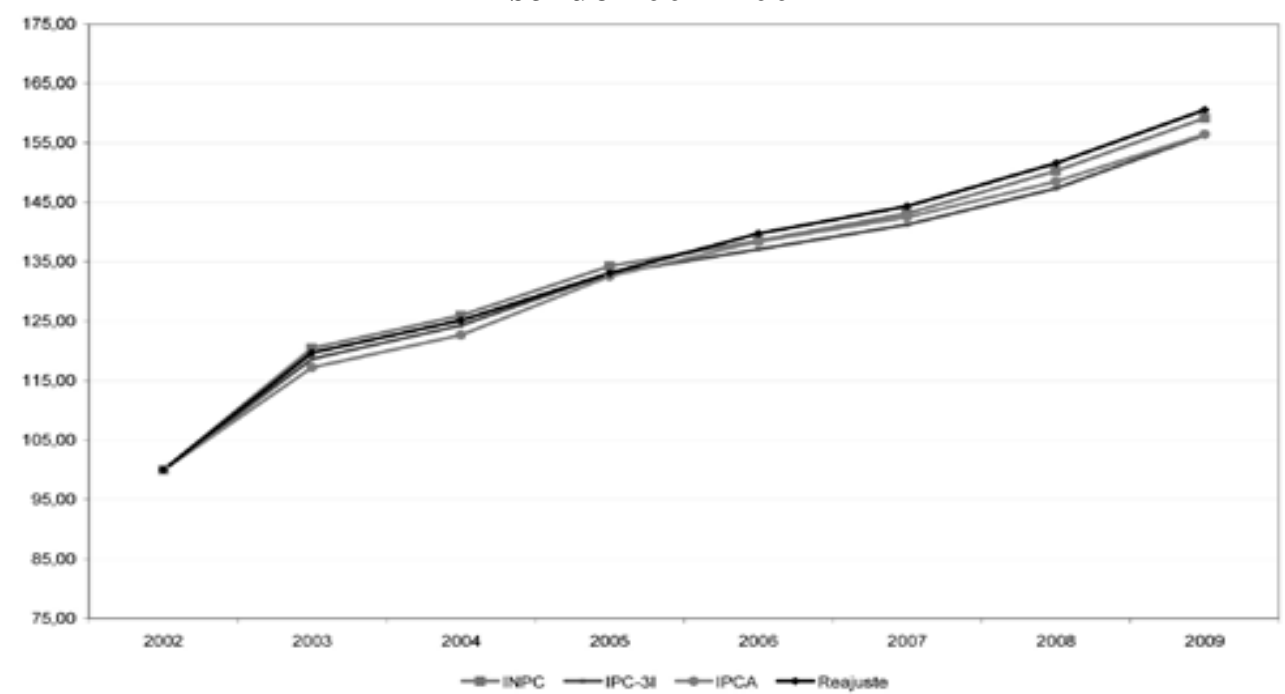

Fonte: IBGE; FGV - Elaboração: SPS/MPS.

Depois de densa argumentação e simulações numéricas, concluem Ansiliero e Costanzi (2009, p. 198) que

(...) uma eventual mudança de regra, para que todos passassem a ter reajuste igual ao do salário mínimo, seria negativa do ponto de vista distributivo, ao "congelar" a estrutura de rendimentos no âmbito da Seguridade Social e representar uma expressiva transferência adicional de recursos para os $50 \%$ mais ricos, caso fosse mantida a política de valorização do salário mínimo. Contudo, dada os expressivos impactos fiscais da referida medida, muito provavelmente, essa medida iria comprometer a política de valorização do salário mínimo.

Portanto, pode-se afirmar que: a) são falsas as afirmações que os beneficiários que ganham acima do piso tenham tido perda de poder de compra no período de 2003 a 2009, quando se considera o INPC, o IPCA e o IPC 3i; b) 2 em cada 3 beneficiários da Previdência e Assistência Social têm tido expressivos ganhos reais em função da valorização do salário mínimo; c) do ponto de vista legal, a Constituição veda qualquer vinculação ao salário mínimo; d) a referida vinculação seria extremamente prejudicial do ponto de vista distributivo; e) a proposta de reajuste para todos iguais ao salário mínimo é insustentável do ponto de vista fiscal e acabaria por comprometer a continuidade do processo de valorização do piso legal de remuneração e previdenciário, prejudicando justamente aqueles de mais baixa renda no âmbito da Seguridade Social.

\subsection{Cobertura previdenciária do Rio Grande do Norte}

No Rio Grande do Norte, a cobertura previdenciária dos trabalhadores ocupados com idade entre 16 e 59 anos, no ano de 2008, ficou no percentual de 56,7\%, substancialmente 
inferior a média nacional que, no mesmo ano, foi de 65,9\%. É o sétimo mais baixo índice de cobertura previdenciária, deixando o RN à frente apenas dos estados de RR (56,6\%), MA (56\%), AC (55,5\%), PB (55,3\%). CE (51\%) e PA (46,7\%).

A baixa cobertura em idade jovem é fortemente influenciada pela precariedade do emprego formal, no campo e na cidade, a corroborar esta possibilidade vê-se no Gráfico 17 que a taxa de inclusão previdenciária é declinante das unidades federativas mais industrializadas (Regiões Sul, Sudeste e Centro-Oeste) para as menos industrializadas (Regiões Norte e Nordeste).

Quando se analisa a cobertura previdenciária das pessoas idosas, Gráfico 18, a situação do RN reverte-se diametralmente. No ano de 2008, a média da cobertura previdenciária aos idosos residentes no estado potiguar foi de $87 \%$, ultrapassando a média nacional que, no mesmo ano, foi de $81,79 \%$, destacando-se como a quarta maior cobertura do país, ficando atrás apenas do PI $(90,4 \%), \mathrm{SC}(89,6 \%)$ e RS $(88,7)$.

\section{Gráfico 17}

Cobertura Social por Unidade da Federação* - 2008- (Inclusive Área Rural da Região Norte) - entre 16 e 59 anos de Idade

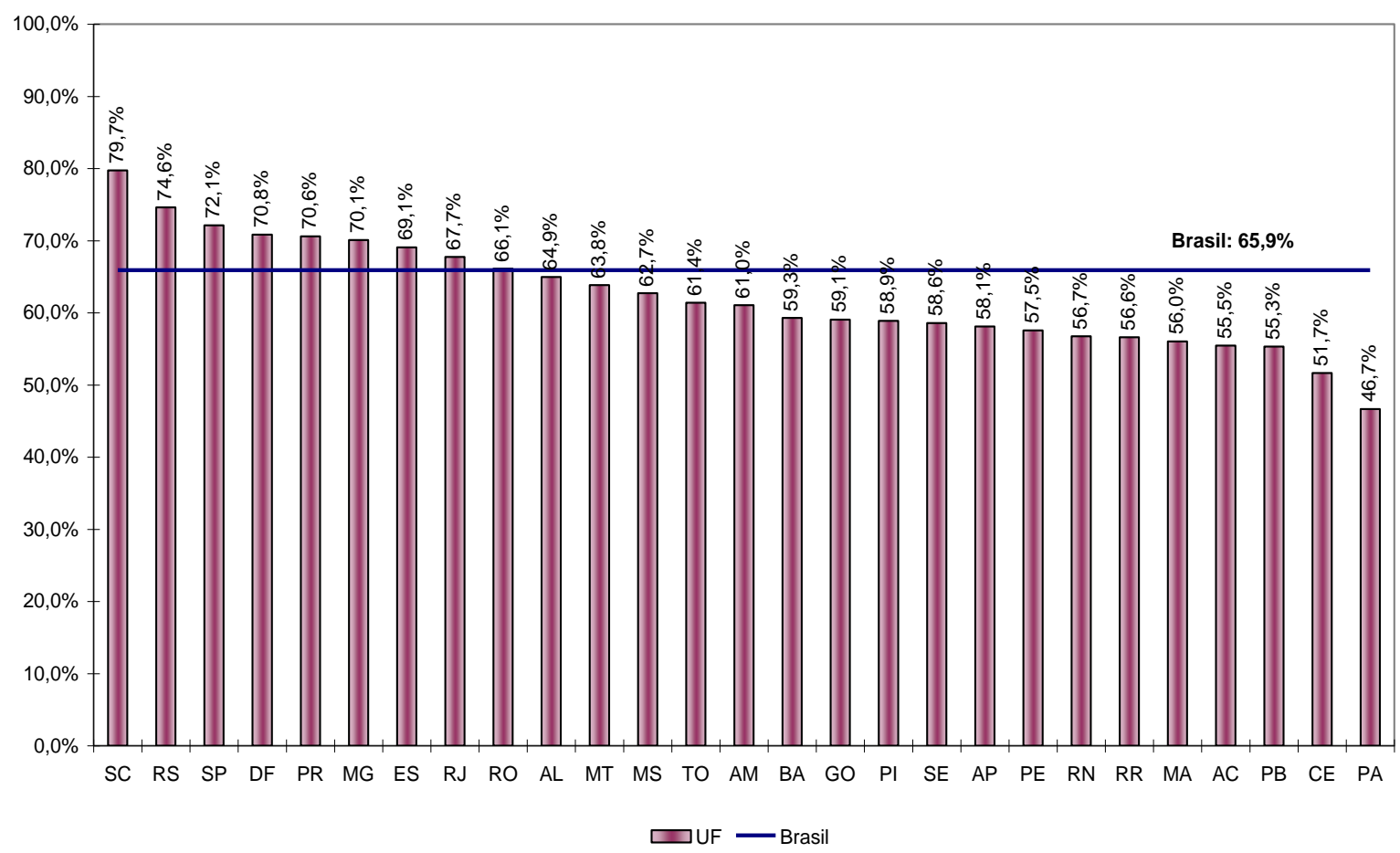

Fonte: PNAD/IBGE - 2008. Elaboração: SPS/MPS.

* Independentemente de critério de renda. 
Quando se analisa a cobertura previdenciária das pessoas idosas, Gráfico 18, a situação do RN reverte-se diametralmente. No ano de 2008, a média da cobertura previdenciária aos idosos residente no $\mathrm{RN}$ foi de $87 \%$, ultrapassando a média nacional que, no mesmo ano, foi de $81,79 \%$, destacando-se como a quarta maior do país, ficando atrás apenas do PI $(90,4 \%)$, SC $(89,6 \%)$ e RS $(88,7)$.

\section{Gráfico 18}

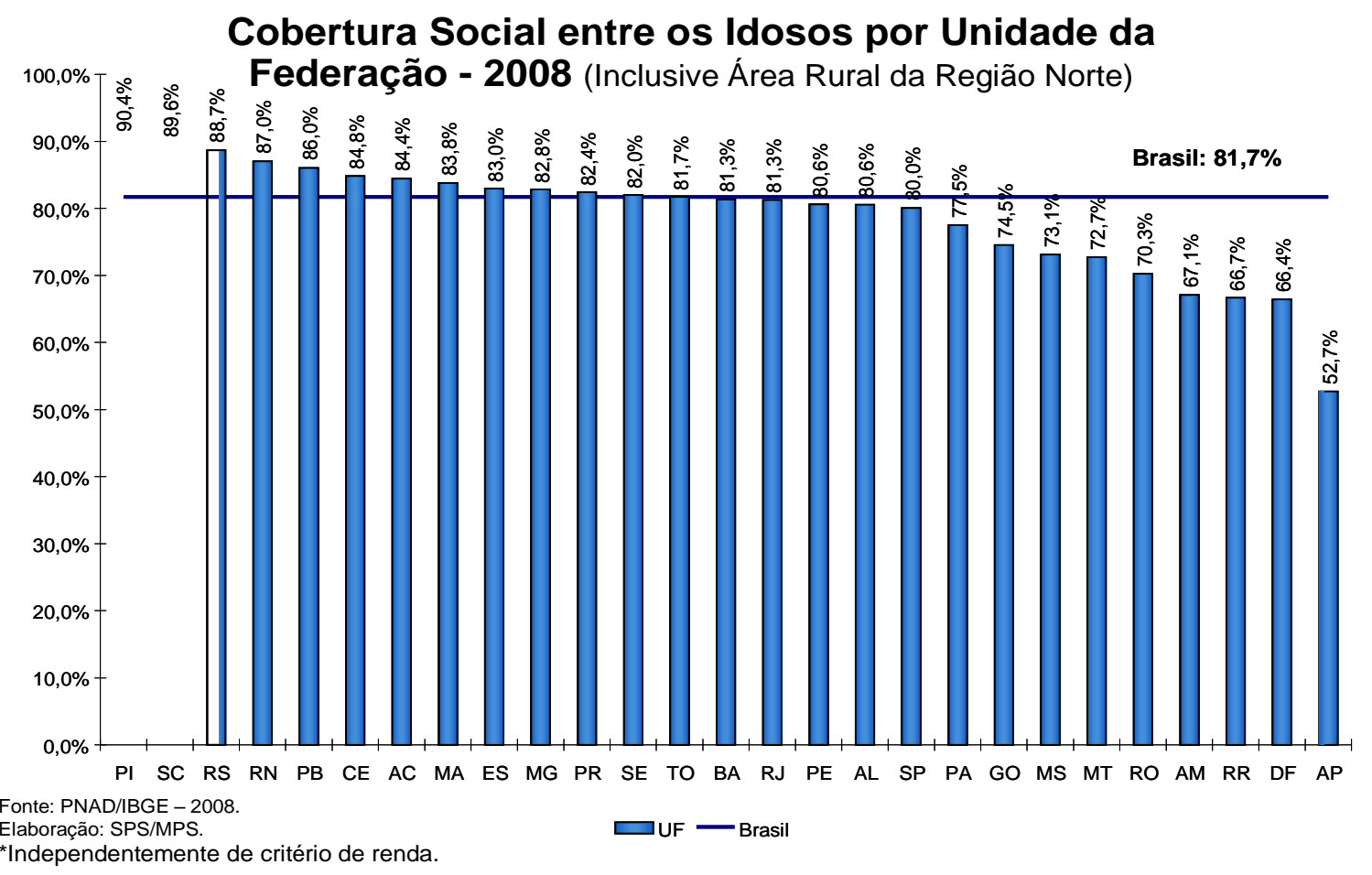

Esta elevada cobertura previdenciária dos idosos potiguares pode ser atribuída à majoritária clientela rural, como já apresentado, e aos benefícios assistenciais de prestação continuada ao idoso e ao deficiente físico, pois em face da baixa cobertura na idade jovem (entre 16 a 59 anos de idade), o acesso à proteção social no RN dá-se em relevante proporção por intermédio dos benefícios não contributivos. A reforçar esta hipótese, vê-se no Quadro 13 que, no período de 2001/2008, as principais espécies de benefícios concedidos no estado potiguar foram a aposentadoria por idade e a pensão por morte (benefícios cuja maior parte da clientela é constituída de trabalhadores rurais), e no campo assistencial, o benefício de prestação continuada (BPC/LOAS). 


\begin{tabular}{|c|c|c|c|c|c|c|c|c|c|}
\hline QUANTIDAD & $\begin{array}{r}\text { DE CF } \\
\text { CAD }\end{array}$ & $\begin{array}{l}\text { DITOS } \\
\text { STRO, } 1\end{array}$ & $\begin{array}{l}\text { ITIDC } \\
\text { ESPI }\end{array}$ & $\begin{array}{l}\text { Quadro } \\
\text { PARA } \\
\text { IES, NC }\end{array}$ & $\begin{array}{l}\text { GAN } \\
\text { IO G }\end{array}$ & $\begin{array}{l}\text { TO DE B } \\
\text { NDE DO }\end{array}$ & $\begin{array}{l}\text { NE } \\
\text { JOR }\end{array}$ & $\mathbf{S A}$ & S NO \\
\hline & & Contet & ido: Qua & tidade B & enefícios 1 & Emitidos & & & \\
\hline & & & & & Ano & & & & \\
\hline $\begin{array}{l}\text { Espécie de } \\
\text { Benefício }\end{array}$ & 2001 & 2002 & 2003 & 2004 & 2005 & 2006 & 2007 & 2008 & Total \\
\hline Total & 355.540 & 372.538 & 384.401 & 404.858 & 419.172 & 429.128 & 436.643 & 4477.596 & \begin{tabular}{|l}
3.601 .899 \\
\end{tabular} \\
\hline $\begin{array}{c}\text { BENEFÍCIOS } \\
\text { DO RGPS }\end{array}$ & 300.060 & 316.342 & 328.386 & 345.674 & 358.037 & 366.491 & 373.115 & 382.616 & 3.066 .757 \\
\hline Previdenciários & 293.760 & 309.720 & 321.670 & 338.804 & 351.206 & 359.610 & 365.892 & 374.819 & 3.005 .439 \\
\hline Aposentadorias & 208.831 & 216.344 & 224.113 & 233.748 & 242.311 & 249.552 & 255.565 & 262.345 & 2.099 .906 \\
\hline $\begin{array}{c}\text { Tempo de } \\
\text { Contribuição } \\
\end{array}$ & 21.678 & 22.570 & 23.366 & 24.675 & 24.917 & 25.707 & 26.808 & 27.317 & 218.528 \\
\hline Idade & 137.520 & 144.089 & 150.546 & 157.620 & \begin{tabular}{|l|l|}
164.481 \\
\end{tabular} & 170.757 & 176.113 & \begin{tabular}{|l|l|}
182.118 \\
\end{tabular} & 1.418 .847 \\
\hline Invalidez & 49.633 & 49.685 & 50.201 & 51.453 & 52.913 & 53.088 & 52.644 & 52.910 & 462.531 \\
\hline $\begin{array}{c}\text { Pensões por } \\
\text { Morte }\end{array}$ & 75.049 & 78.070 & 80.611 & 84.002 & 86.692 & 89.486 & 92.431 & 95.474 & 754.759 \\
\hline Auxílios & 8.655 & 12.964 & 15.573 & 19.697 & 20.949 & 19.411 & 17.009 & 15.837 & 137.754 \\
\hline Doença & 8.372 & 12.655 & 15.172 & 19.194 & 20.338 & 18.582 & 16.051 & 14.757 & 132.619 \\
\hline Reclusão & 149 & 134 & 200 & 280 & 346 & 387 & 389 & 376 & 2.355 \\
\hline Acidente & 134 & 175 & 201 & 223 & 265 & 442 & 569 & 704 & 2.780 \\
\hline $\begin{array}{c}\text { Salário- } \\
\text { Maternidade }\end{array}$ & 1.165 & 2.285 & 1.316 & 1.303 & 1.201 & 1.130 & 863 & 1.144 & 12.601 \\
\hline Outros & 60 & 57 & 57 & 54 & 53 & 31 & 24 & 19 & 419 \\
\hline $\begin{array}{c}\text { Abono de } \\
\text { Permanência }\end{array}$ & 60 & 57 & 57 & 54 & 53 & 31 & 24 & 19 & 419 \\
\hline Acidentários & 6.300 & 6.622 & 6.716 & 6.870 & 6.831 & 6.881 & 7.223 & 7.797 & 61.318 \\
\hline $\begin{array}{c}\text { Aposentadoria } \\
\text { por Invalidez }\end{array}$ & 968 & 992 & 998 & 1.039 & 1.082 & 1.106 & 1.100 & 1.124 & 9.365 \\
\hline Pensão por Morte & 1.512 & 1.522 & 1.518 & 1.527 & 1.524 & 1.523 & 1.518 & 1.515 & 13.657 \\
\hline Auxílios & 3.820 & 4.108 & 4.200 & 4.304 & 4.225 & 4.252 & 4.605 & 5.158 & 38.296 \\
\hline Doença & 457 & 607 & 663 & 742 & 633 & 617 & 997 & 1.536 & 6.641 \\
\hline Acidente & 2.398 & 2.531 & 2.580 & 2.613 & 2.666 & 2.726 & 2.722 & 2.751 & 23.262 \\
\hline Suplementar & 965 & 970 & 957 & 949 & 926 & 909 & 886 & 871 & 8.393 \\
\hline $\begin{array}{c}\text { BENEFÍCIOS } \\
\text { ASSISTENCIAIS }\end{array}$ & 55.474 & 56.188 & 56.007 & 59.176 & 61.126 & 62.541 & 63.439 & 64.895 & 534.827 \\
\hline $\begin{array}{c}\text { Amparos } \\
\text { Assistenciais }\end{array}$ & 24.802 & 27.654 & 29.421 & 34.469 & 38.234 & 41.600 & 44.254 & 47.022 & 310.887 \\
\hline $\begin{array}{c}\text { Portador de } \\
\text { Deficiência }\end{array}$ & 22.215 & 24.186 & 24.985 & 27.083 & 29.068 & 30.834 & 31.999 & 33.196 & 244.865 \\
\hline Idoso & 2.587 & 3.468 & 4.436 & 7.386 & 9.166 & 10.766 & 12.255 & 13.826 & 66.022 \\
\hline $\begin{array}{c}\text { Pensões Mensais } \\
\text { Vitalícias }\end{array}$ & 180 & 171 & 167 & 163 & 156 & 153 & 147 & 139 & 1.466 \\
\hline $\begin{array}{c}\text { Rendas Mensais } \\
\text { Vitalícias } \\
\end{array}$ & 30.492 & 28.363 & 26.419 & 24.544 & 22.736 & 20.788 & 19.038 & 17.734 & 222.474 \\
\hline Rmv Invalidez & 23.808 & 22.402 & 21.101 & 19.829 & 18.587 & 17.249 & 15.991 & 15.002 & 178.947 \\
\hline Rmv Idade & 6.684 & 5.961 & 5.318 & 4.715 & 4.149 & 3.539 & 3.047 & 2.732 & 43.527 \\
\hline EPU & 6 & 8 & 8 & 8 & 9 & 96 & 89 & 85 & 315 \\
\hline
\end{tabular}

Fonte: AEPS/MPS, vários anos. INFOLOGO.

Elaboração: do autor. 
Para exemplificar, em julho de 2009, de 185.076 aposentadorias por idade emitidas no RN, 160.064 foram pagas a aposentados rurais e apenas 25.012 a aposentados urbanos. Dada a baixa cobertura previdenciária na idade jovem, tem-se o inverso quando se verifica a proporção de rurais e urbanos na emissão de aposentadorias por tempo de contribuição, benefício eminentemente contributivo frente ao qual a clientela rural tem raro acesso. No mesmo mês de julho de 2009, de 28.137 aposentadorias por tempo de contribuição emitidas no $\mathrm{RN}$, apenas 40 foram pagas a trabalhadores rurais ${ }^{22}$. Ainda no mês de julho de 2009 , as aposentadorias por idade representavam $48,7 \%$ do estoque de benefícios emitidos no RN, enquanto que a média nacional no mesmo mês foi de 34,3\%. Reflexo do alto contingente de beneficiários rurais é que aproximadamente $85 \%$ dos benefícios emitidos no $\mathrm{RN}$ têm valor de até 1 salário mínimo.

\subsection{Impactos da Previdência Social na renda da população e na redução do nível de pobreza}

O expressivo aumento do número de benefícios emitidos e do respectivo aumento do valor monetário transferido aos beneficiários residentes nos municípios do $\mathrm{RN}$ tem reflexo direto na redução do nível de pobreza e na composição da renda das famílias.

De acordo com a PNAD 2008, no Rio Grande do Norte, as transferências previdenciárias reduziram o contingente de pessoas vivendo abaixo da linha de pobreza absoluta (rendimento médio domiciliar per capita de até meio salário mínimo mensal) em $14,1 \%$ pontos percentuais, o que ultrapassa a média nacional que no mesmo período foi de 12,3\%. Trata-se do sexto maior impacto sobre a pobreza entre as unidades federativas, ficando o RN atrás apenas dos estados do PI (17,6\%), PB (16\%), RJ (15,5\%), RS (14,6\%) e CE (14,6\%), conforme retrata o Gráfico 17.

\footnotetext{
${ }^{22}$ As informações deste parágrafo foram extraída do Boletim Estatístico da Previdência Social - NE - Rio Grande do Norte - vol. 02, n. ${ }^{\circ}$ 01, julho/2009.
} 
Gráfico 19

Pontos Percentuais de Redução de Pobreza no Brasil em função das Transferências Previdenciárias por UF - 2008 (Inclusive Área Rural da Região Norte)

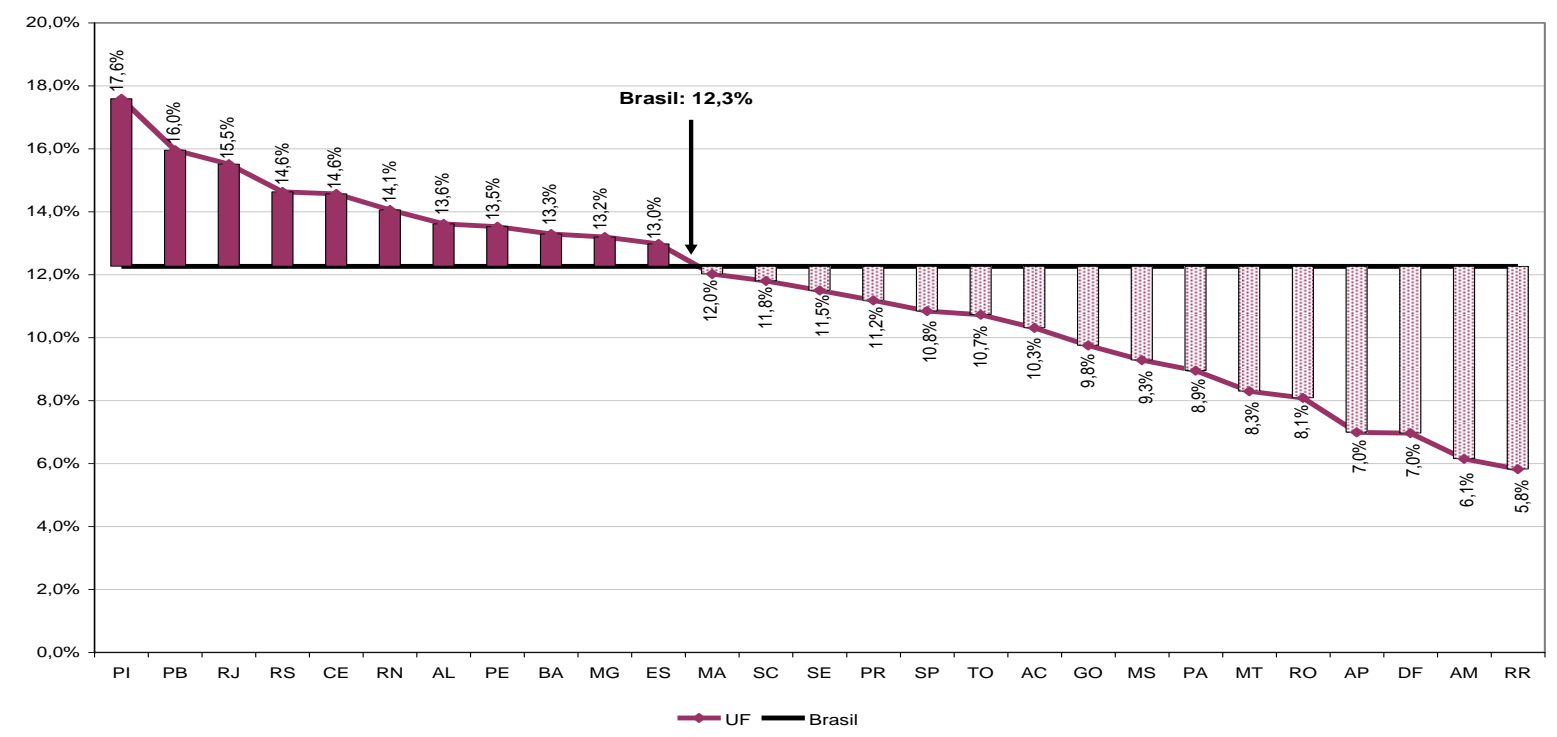

Fonte: PNAD/IBGE 2008. Elaboração: SPS/MPS.

Nota: Foram considerados apenas os habitantes de domicílios onde todos os moradores declararam a integralidade de seus rendimentos.

Sem apontar as causas desta redução, o Comunicado n. ${ }^{\circ} 58$ do IPEA (2010b) indica que, no RN, entre 1995 e 2008, o percentual de pessoas em condições de pobreza absoluta (rendimento médio domiciliar per capita de até meio salário mínimo mensal) passou de 63,8\% para 44,2\% da população, segundo menor percentual da Região Nordeste.

No caso da taxa de pobreza extrema (rendimento médio domiciliar per capita de até um quarto de salário mínimo mensal), o mesmo estudo aponta que o $\mathrm{RN}$ reduziu esta categoria de pobreza, de 34,3\%, em 1995, para 20,2\%, em 2008, índice mais baixo entre os estados da Região Nordeste.

O estudo também apontou redução na desigualdade da renda, medida pelo índice Gini, que passou de 0,60 para $0,55^{23}$, no RN

A importância da renda previdenciária é corroborada ainda pelo Comunicado IPEA n. ${ }^{\circ}$ 59 (2010c) de que, em 2008, 23,8\% da composição da renda das famílias residentes no RN originaram-se de transferências sociais previdenciárias e assistenciais (PBC/LOAS e Bolsa Família). Ou seja, quase um quarto da renda familiar no estado advém destas políticas sociais.

\footnotetext{
${ }^{23} \mathrm{O}$ índice Gini varia de 0 a 1, quanto mais próximo de 1 , maior a desigualdade.
} 
Como observado por IPEA (2010c), esta informação não é relevante apenas para as questões de pobreza e desigualdade de renda, mas deve ser objeto de reflexão também por outras áreas. Se faixas significativas, de aproximadamente um quarto da renda das famílias de um estado, originam-se de transferências sociais, então se estabelece de imediato uma conexão entre as políticas sociais, o consumo das famílias, e toda a dinâmica econômica mobilizada a partir daí no comércio e na indústria de bens de consumo durável e não-durável, bem como no setor serviços.

É inequívoco que a transferência de renda advinda da previdência rural tem posição de destaque na composição da renda da família rural potiguar, pois, como visto, no $\mathrm{RN}$, a clientela rural supera numericamente a urbana. E a importância destes recursos avulta-se ainda mais nas localidades menos desenvolvidas, que contam com inexpressiva receita resultante da tributação própria.

Segundo Delgado e Cardoso Jr. (2003), enquanto na região Sul a maior contribuição à renda dos aposentados provém de rendimentos da ocupação principal (52\% da renda domiciliar total), o contrário se dá na região Nordeste, onde apenas $26,3 \%$ da renda provêm da ocupação em atividades agropecuárias, evidenciando a relevância do seguro previdenciário, que contribui com mais de $70 \%$ da renda domiciliar das famílias nordestinas com ou chefiadas por aposentados.

Nos domicílios nordestinos, o tamanho médio das famílias com aposentados chega a 3,93 pessoas. Isso atesta que o benefício previdenciário cobre um número relativamente alto de pessoas no meio rural nordestino, uma vez que é a principal fonte de renda desses domicílios. No semi-árido, a aposentadoria chega a representar $72 \%$ da renda domiciliar total, conforme pesquisa de campo realizada em 1999 (Galindo e Irmão, 2003).

As pesquisas sobre previdência rural geralmente destacam que a renda dos idosos nas áreas rurais é impactante não apenas no orçamento familiar, mas também no nível de atividade econômica. De maneira inesperada, a pesquisa de campo organizada por Delgado e Cardoso Jr. (2003) encontrou atividades agrícolas na maioria dos domicílios com beneficiários da previdência: $48 \%$ no Sul e $43 \%$ no Nordeste. Nos domicílios dessas regiões, respectivamente $44,7 \%$ e $37,0 \%$ do valor dos benefícios são utilizados para custear a produção. 
Observam Delgado e Cardoso Jr., 2003 que a conversão do seguro previdenciário em seguro agrícola introduz um elemento novo na política previdenciária, qual seja: o impacto sobre a produção agropecuária do numeroso setor de agricultura familiar de todo o país e, até mesmo, sobre o vasto segmento de agricultura de subsistência presente no semi-árido nordestino. No geral, a aposentadoria rural propicia a formação de um pequeno excedente de renda nos domicílios dos aposentados e pensionistas rurais que é praticamente reinvestido na própria atividade produtiva familiar, criando condições para uma "reprodução ampliada" dessa economia familiar.

Diante dessa realidade, Galindo e Irmão (2003) admitem que seja fato incontestável que os domicílios que gozam de uma aposentadoria rural desfrutam de uma qualidade de vida melhor do que aqueles que não têm o seguro rural, principalmente no Nordeste do país. Fator extremamente importante é que o seguro previdenciário, ao lado de outras variáveis, atua com um peso fundamental na permanência do aposentado no campo, impedindo sua migração para os centros urbanos. No Nordeste, $74 \%$ dos beneficiários permaneceram em suas residências após a concessão da aposentadoria.

Maia Gomes, citado por Aquino e Souza (2004, p. 07), confirma no seu estudo que pela expansão que teve no Nordeste, principalmente na região do semi-árido, o crescimento das aposentadorias veio a ser a ocorrência de maior impacto para o sertão nordestino nos últimos vinte anos. $\mathrm{Na}$ interpretação daquele autor, num ambiente em que quase 10 milhões de pessoas no semi-árido nordestino praticam uma agricultura e pecuária tradicional, atividades estas que vem se desestruturando a cada dia e totalmente vulneráveis às crises climáticas, a renda proveniente das aposentadorias cria uma "economia resistente às secas" numa vasta área geográfica não contemplada pelos pólos regionais de irrigação e pelas indústrias de calçados e de confecções.

A corroborar que os efeitos positivos verificados no resto do país, especialmente, na Região Nordeste, replicam nos municípios do RN, Aquino e Souza (2004) promoveram, no período de outubro e novembro de 2003, pesquisa teórica e de campo a respeito dos impactos socioeconômicos da Previdência Rural no pequeno município de Encanto, localizado no interior do Rio Grande do Norte.

Ao final da pesquisa, concluíram Aquino e Souza (2004, p. 16): 
A análise dos dados permitiu verificar que a Previdência Rural tem uma função extremamente importante para a reprodução das famílias da localidade, mostrando em muitos casos ser a única fonte de rendimento domiciliar. Além disso, os benefícios recebidos pelos idosos são responsáveis por mais da metade dos rendimentos de mais de $80 \%$ dos domicílios pesquisados e chegam a ser a única fonte de renda monetária para mais de $2 / 3$ dos casos analisados. Os dados mostraram ainda que o dinheiro das aposentadorias representa uma verdadeira "tabua de salvação" para economia do município, com o comércio local funcionando basicamente nos dias de pagamento dos 796 segurados rurais.

Nesse sentido, confirmamos a tese de que a Previdência Rural desempenha um importante papel social no sertão nordestino, sendo um dos principais instrumentos de distribuição de renda e de combate à pobreza no Brasil. Essa realidade se apresentou com bastante clareza no município pesquisado. Como foi observado, sem o pagamento dos benefícios da previdência o número de pessoas abaixo da linha de pobreza e de indigência, sem dúvida, aumentaria significativamente. Esses e outros resultados sociais e econômicos devem ser levados em consideração pela sociedade brasileira e pelos gestores de políticas públicas em qualquer proposta de reforma constitucional relacionada à Seguridade Social no país.

\subsection{Benefícios Líquidos = benefícios emitidos - arrecadação previdenciária}

O efeito redistributivo proporcionado pela previdência rural em favor do Rio Grande do Norte pode ser dimensionado pela diferença entre o valor dos benefícios emitidos nesta unidade federativa (transferência de rendas previdenciárias) e o correspectivo valor arrecadado no mesmo período.

Neste trabalho, o referencial primário para a caracterização de políticas redistributivas é constituído pela tipologia proposta por Lowi (1964) para a classificação de políticas públicas. De acordo com a sua contribuição seminal, as políticas redistributivas compreendem aquela que proporciona a redistribuição de vantagens ou benefícios entre grupos sociais, tirando recursos de um determinado grupo em favor de outros, buscando equidade e provocando conflitos.

Analisando vários trabalhos sobre a tipologia de Lowi, explica Souza (2010, p. 09) que as arenas ou políticas redistributivas "seriam vistas como tomando benefícios de outros grupos, envolvendo conflitos sobre legitimidade da ação e do conteúdo específico. As demandas bestariam associadas a uma retórica de luta de classes e integradas (coesão de membros do grupo etc.), pressuporiam um executivo forte e exemplifica estas políticas com taxações". 
Seguindo fiel à conceituação empregada nas informações repassadas pelo MPS, o valor dos benefícios emitidos corresponde ao valor líquido (diferença entre valor bruto e descontos) dos créditos emitidos na "folha de pagamentos da Previdência Social" (maciça), classificados pelo município do órgão pagador (onde o segurado recebe seu benefício). Já o Valor arrecadado compreende os recolhimentos provenientes de todas as receitas incluídas na guia de recolhimento da Previdência Social - GPS ${ }^{24}$.

No ano de 2009, os 167 municípios do RN arrecadaram R $\$ 1.211$ bilhões em receita previdenciária e receberam em pagamento de benefícios o valor líquido de $\mathrm{R} \$ 2.886$ bilhões, gerando, assim, para estes municípios superávit da ordem de $\mathrm{R} \$ 1.674$ bilhões. $\mathrm{O}$ superávit previdenciário no RN é fortemente influenciado pela alta cobertura proporcionada pela previdenciária rural da qual resulta uma baixa relação entre o valor dos benefícios emitidos e a respectiva contribuição previdenciária.

Na série de 2002 a 2007, o RN arrecadou contribuições previdenciárias entre 3,3\% a 4,2\% de seu PIB e, em contrapartida, no mesmo período, recebeu a título de crédito de pagamentos de benefícios valores que variaram entre 9,3\% a 10,3\% do seu PIB, resultando em favor dos municípios potiguares ganho monetário proporcional a 5,79\% a 6,58\% de toda riqueza produzida no estado.

\section{QUADRO 15}

Relação do PIB do RN com o Valor dos Benefícios e a Arrecadação Previdenciária

\begin{tabular}{|c|c|c|c|c|c|c|c|}
\hline $\begin{array}{c}\mathbf{A N} \\
\mathbf{O}\end{array}$ & $\begin{array}{l}\text { (A) PIB do } \\
\text { RN em R\$ }\end{array}$ & $\begin{array}{l}\text { (B) Valor } \\
\text { dos } \\
\text { benefícios } \\
\text { em R\$ }\end{array}$ & $\begin{array}{c}\text { (A/B) } \\
\text { \% dos } \\
\text { Benefício } \\
\text { s em } \\
\text { relação } \\
\text { ao } \\
\text { PIB/RN }\end{array}$ & $\begin{array}{c}(\mathrm{C}) \\
\text { Arrecadação } \\
\text { Previdenciári } \\
\text { a no RN em } \\
\text { R\$ }\end{array}$ & $\begin{array}{l}\text { (A/C) \% da } \\
\text { Arrecadaçã } \\
\text { o em } \\
\text { relação ao } \\
\text { PIB/RN }\end{array}$ & $\begin{array}{c}\text { (D) } \\
\text { Valor dos } \\
\text { Benefícios - } \\
\text { arrecadação } \\
\text { em R\$ }\end{array}$ & $\begin{array}{c}\text { (A/D) \% } \\
\text { do } \\
\text { Superávi } \\
\text { t em } \\
\text { relação } \\
\text { ao } \\
\text { PIB/RN }\end{array}$ \\
\hline 2001 & & 991.535 .879 & & 328.889 .428 & & 662.646 .451 & \\
\hline 2002 & $\begin{array}{c}12.198 .000 .00 \\
0\end{array}$ & $\begin{array}{c}1.144 .314 .34 \\
0\end{array}$ & $9,38 \%$ & 414.224 .912 & $3,39 \%$ & 730.089 .427 & $5,98 \%$ \\
\hline 2003 & $\begin{array}{c}13.515 .000 .00 \\
0 \\
\end{array}$ & $\begin{array}{c}1.397 .934 .00 \\
6 \\
\end{array}$ & $10,34 \%$ & 532.571 .697 & $3,94 \%$ & 865.362 .308 & $6,40 \%$ \\
\hline 2004 & $\begin{array}{c}15.580 .000 .00 \\
0\end{array}$ & $\begin{array}{c}1.609 .848 .53 \\
7\end{array}$ & $10,33 \%$ & 585.138 .605 & $3,75 \%$ & $\begin{array}{c}1.024 .709 .63 \\
1\end{array}$ & $6,58 \%$ \\
\hline
\end{tabular}

\footnotetext{
${ }^{24}$ Abrangem receitas de contribuições sociais de empresas, entidades equiparadas e contribuintes em geral, débitos e parcelamentos administrativos e judiciais, receitas patrimoniais, devolução de benefícios, reclamatórias trabalhistas e outros. Inclui as contribuições relativas a outras entidades (SESC, INCRA, Salário Educação) e os acréscimos legais (atualização monetária, juros e multas). Os dados são por local de pagamento e o mês de referência é o de processamento da GPS (mês civil).
} 


\begin{tabular}{|c|c|c|c|c|c|c|c|}
\hline $\mathbf{2 0 0 5}$ & $\begin{array}{c}17.870 .000 .00 \\
\end{array}$ & $\begin{array}{c}1.823 .950 .64 \\
6\end{array}$ & $\mathbf{1 0 , 2 1 \%}$ & 695.519 .002 & $\mathbf{3 , 8 9 \%}$ & $\begin{array}{c}1.128 .431 .64 \\
4\end{array}$ & $\mathbf{6 , 3 1 \%}$ \\
\hline $\mathbf{2 0 0 6}$ & $\begin{array}{c}20.557 .000 .00 \\
0\end{array}$ & $\begin{array}{c}2.092 .568 .36 \\
2\end{array}$ & $\mathbf{1 0 , 1 8 \%}$ & 807.332 .555 & $\mathbf{3 , 9 3} \%$ & $\begin{array}{c}1.285 .235 .80 \\
7\end{array}$ & $\mathbf{6 , 2 5 \%}$ \\
\hline $\mathbf{2 0 0 7}$ & $\begin{array}{c}22.926 .000 .00 \\
0\end{array}$ & $\begin{array}{c}2.290 .248 .11 \\
7\end{array}$ & $\mathbf{9 , 9 9 \%}$ & 963.632 .293 & $\mathbf{4 , 2 0 \%}$ & $\begin{array}{c}1.326 .615 .82 \\
4\end{array}$ & $\mathbf{5 , 7 9 \%}$ \\
\hline $\mathbf{2 0 0 8}$ & & $\begin{array}{c}2.517 .030 .38 \\
4\end{array}$ & & 1.180 .157 .875 & & $\begin{array}{c}1.336 .872 .50 \\
9\end{array}$ & \\
\hline $\mathbf{2 0 0 9}$ & & $\begin{array}{c}2.886 .389 .20 \\
3\end{array}$ & & 1.211 .611 .971 & & $\begin{array}{c}1.674 .777 .23 \\
2\end{array}$ & \\
\hline
\end{tabular}

Fontes: Arrecadação e benefícios, AEPS, vários anos. Infologo, de 2001 a 2008. Síntese/DATAPREV, em 2009. PIB, AERN, 2007. Os Valores da coluna (A) foram arredondados, e em todas as colunas em $\mathrm{R} \$$ foram excluídos os centavos.

Elaboração: do autor

O Gráfico 20 representa a trajetória evolutiva das transferências monetárias decorrente do pagamento de benefícios no RN e a respectiva evolução da arrecadação previdenciária.

\section{Gráfico 20}

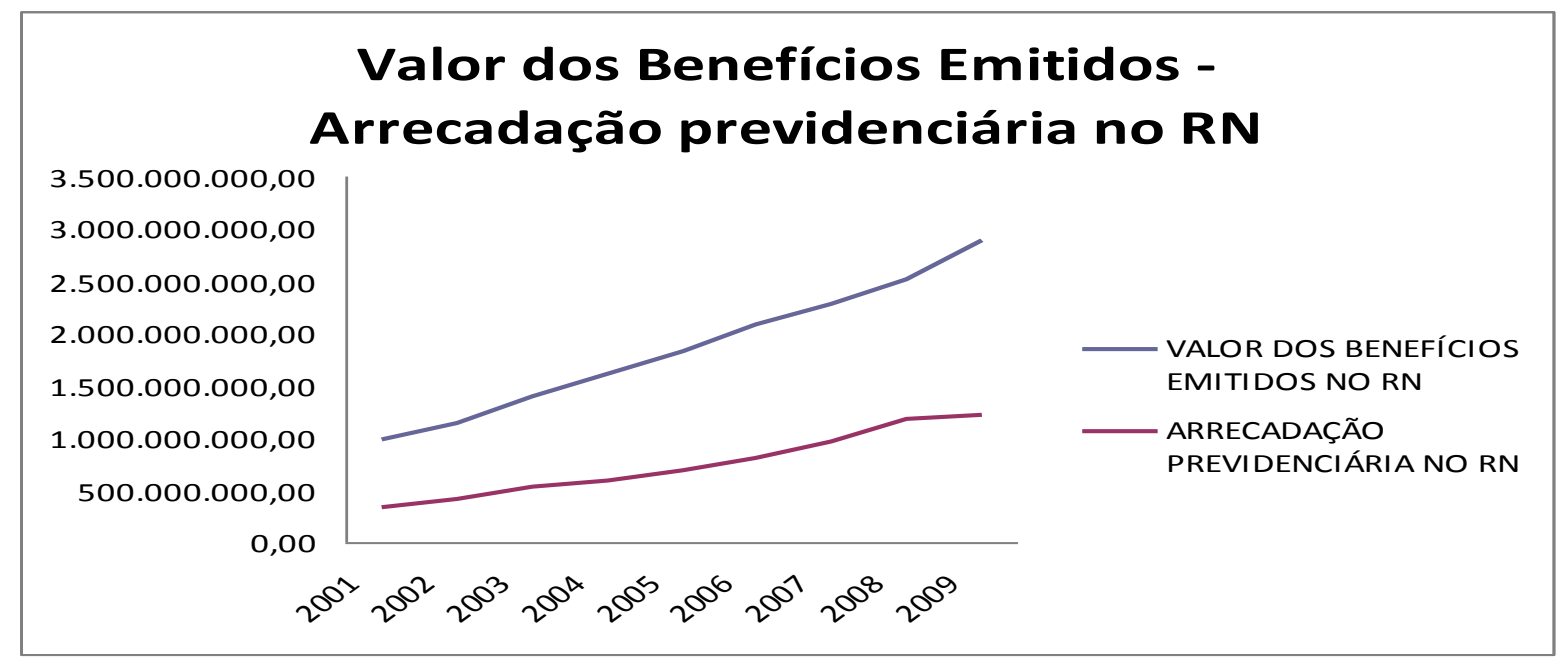

Fontes: AEPS/MPS, vários anos. INFOLOGO. Em 2009, SÍNTESE/DATAPREV.

Elaboração: do autor.

O superávit na relação pagamento de benefício e a correspectiva arrecadação previdenciária coloca o $\mathrm{RN}$ entre os estados beneficiados pelo efeito redistributivo interregional da Previdência Social, pois arrecada contribuições sociais vinculadas tradicionalmente à despesa previdenciária em proporção significativamente inferior ao que paga em benefícios.

Esta suposição ampara-se no disposto no inciso $\mathrm{X}$, do art. 167, da CF/88, cujo comando veda a utilização dos recursos provenientes das contribuições previdenciárias de que trata o art. 195, I, $a$, e II (pagas pelo empregador sobre folha de salários e pelo trabalhador também sobre sua verba salarial), para a realização de despesas distintas do pagamento de 
benefícios do RGPS, permitindo, assim, considerar que o expressivo déficit de arrecadação previdenciária no RN é suprido, em grande parte, pelo excesso de arrecadação previdenciária verificada nos municípios de maior PIB, acabando por funcionar a política previdenciária como um importante fator de diminuição das desigualdades regionais.

\subsection{Comparativo: valor dos benefícios $x$ transferências fiscais}

O Quadro 16 e o Gráfico 21 mostram que, de 2001 a 2009, o valor dos benefícios previdenciários pagos aos beneficiários residentes no RN supera significativamente as transferências do Fundo de Participação dos Municípios (FPM) e do Fundo de Participação dos Estados (FPE) destinado ao estado potiguar.

Quando se considera o valor total dos benefícios pagos, abrangendo os beneficiários rurais e urbanos, as transferências monetárias da Previdência Social são superiores aos repasses do FPE e representa quase o triplo das transferências constitucionais do FPM aos municípios do RN.

\section{Quadro 16}

\begin{tabular}{|c|c|c|c|c|c|}
\cline { 3 - 6 } \multicolumn{1}{l|}{} & FPM/RN & FPE/RN & \multicolumn{2}{c|}{ VALOR DOS BENEFÍCIOS EMITIDOS NO RN } \\
\cline { 3 - 6 } \multicolumn{1}{l|}{} & & & RURAL & URBANO & $\begin{array}{c}\text { TOTAL } \\
\text { (Rural + Urbano) }\end{array}$ \\
\hline $\mathbf{2 0 0 1}$ & $371.624 .119,62$ & $598.964 .545,41$ & $420.644 .755,17$ & $570.891 .124,08$ & $991.535 .879,25$ \\
\hline $\mathbf{2 0 0 2}$ & $459.963 .081,29$ & $741.268 .901,16$ & $486.891 .725,64$ & $657.422 .614,89$ & $1.144 .314 .340,53$ \\
\hline $\mathbf{2 0 0 3}$ & $478.285 .252,10$ & $771.144 .603,19$ & $597.603 .828,00$ & $800.330 .178,00$ & $1.397 .934 .006,00$ \\
\hline $\mathbf{2 0 0 4}$ & $536.195 .552,79$ & $850.016 .834,65$ & $681.498 .850,00$ & $928.349 .687,00$ & $1.609 .848 .537,00$ \\
\hline $\mathbf{2 0 0 5}$ & $662.073 .677,81$ & $1.063 .839 .646,64$ & $784.134 .496,00$ & $1.039 .816 .150,00$ & $1.823 .950 .646,00$ \\
\hline $\mathbf{2 0 0 6}$ & $732.334 .633,72$ & $1.177 .370 .259,83$ & $916.691 .491,46$ & $1.175 .876 .871,32$ & $2.092 .568 .362,78$ \\
\hline $\mathbf{2 0 0 7}$ & $842.332 .110,47$ & $1.337 .333 .073,57$ & $1.005 .748 .039,80$ & $1.284 .500 .077,74$ & $2.290 .248 .117,54$ \\
\hline $\mathbf{2 0 0 8}$ & $1.067 .223 .660,73$ & $1.602 .245 .221,50$ & $1.111 .187 .516,19$ & $1.405 .842 .868,61$ & $2.517 .030 .384,80$ \\
\hline $\mathbf{2 0 0 9}$ & $989.113 .432,34$ & $1.512 .667 .661,39$ & 1.281 .692 .861 & $1.604 .696 .342,00$ & $2.886 .389 .203,00$ \\
\hline
\end{tabular}

Fontes: FPM e FPE, Secretaria do Tesouro Nacional do Ministério da Fazenda (STN/MF). Os valores referentes a soma dos benefícios previdenciários urbanos e rurais emitidos no ano de 2001/2008, AEPS, vários anos, de 2009, SINTESE/DATAPREV.

Notas: 
(1) de 2001/2006, dos valores do FPM e do FPE já está descontada a parcela de $15 \%$ (quinze por cento) destinada ao FUNDEF.

(2) A partir 2007, dos valores do FPM e do FPE, já está descontada a parcela destinada ao FUNDEB.

(3) O Valor dos benefícios emitidos corresponde ao valor líquido (diferença entre valor bruto e descontos) dos créditos emitidos pelo Instituto Nacional de Previdência Social - INSS para pagamento de benefícios do Regime Geral de Previdência Social, Encargos Previdenciários da União e Amparos Assistenciais previstos na Lei Orgânica da Assistência Social, classificados pelo município do órgão pagador.

\section{Gráfico 21}

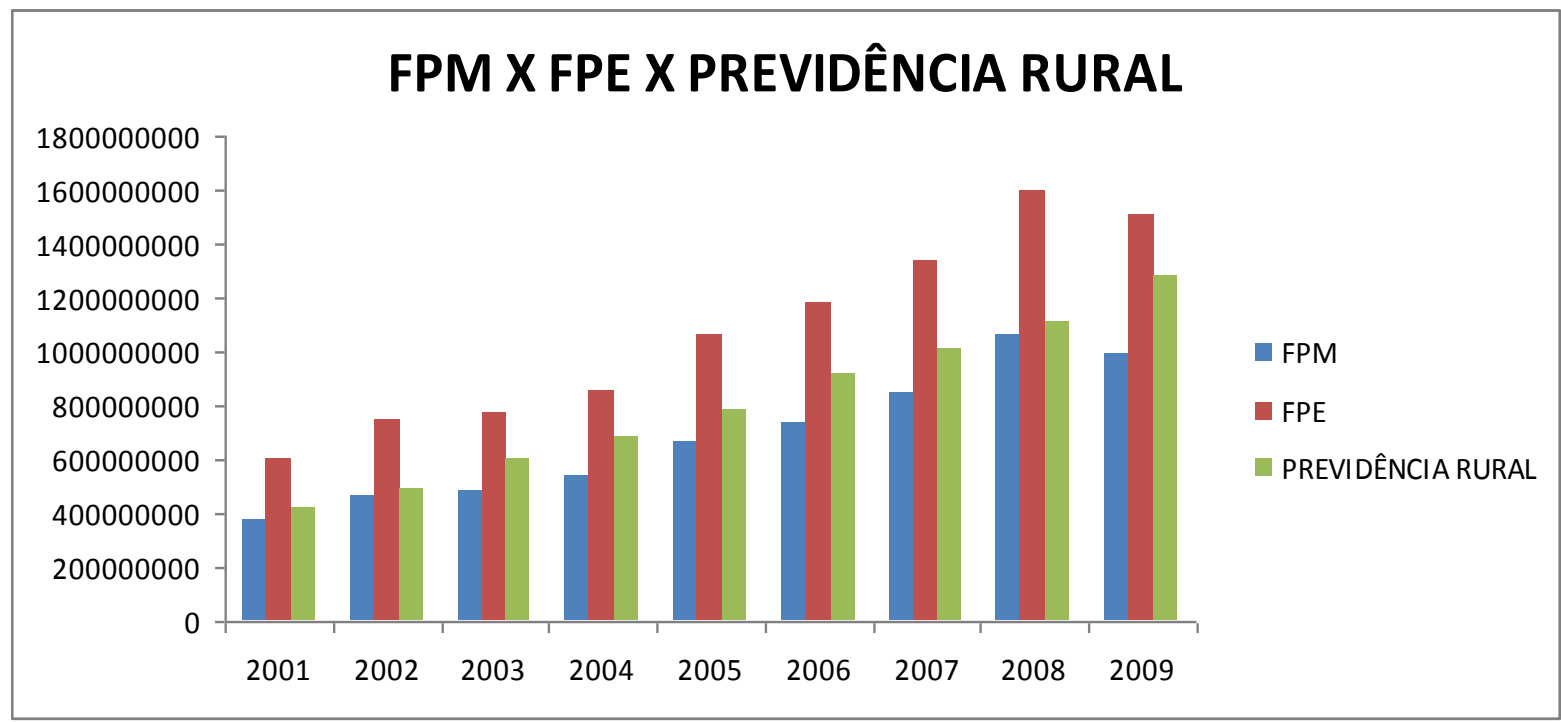

Fontes: AEPS/MPS, vários anos. INFOLOGO. Em 2009, SÍNTESE/DATAPREV.

Elaboração: do autor

Assim, em 2009, o crédito líquido total resultante do pagamento de benefícios previdenciários nos municípios do $\mathrm{RN}$ equivale a 2,91 vezes o valor total repassado do FPM aos mesmos municípios.

O Quadro 16 mostra que mesmo se considerado apenas o crédito líquido decorrente do pagamento de benefícios previdenciários à clientela rural, ainda assim este valor é maior que as transferências do FPM, e esta superioridade se apresenta em todo o período de 2001 a 2009. Por exemplo, em 2009, o valor total, anual dos pagamentos feitos pela Previdência Social à clientela rural do $\mathrm{RN}$ supera em aproximadamente $\mathrm{R} \$ 300$ milhões a quantia transferida pelo FPM para os municípios do mesmo estado.

Nos Apêndices I a III encontram-se organizadas informações sobre receita orçamentária própria, a cota-parte do FPM e do ICMS referente a cada um dos municípios potiguares com intuito de permitir dimensionar com maior riqueza de detalhes a relevância 
socioeconômica da renda decorrente do pagamento de benefícios do RGPS na economia destes municípios.

O Apêndice I estabelece comparação, referente ao ano de 2008, do valor dos benefícios emitidos em cada um dos 167 municípios do RN, considerando isolada e conjuntamente a clientela rural e urbana, com as principais fontes de receitas de cada um destes mesmos municípios, a saber, receitas próprias, FPM e COTA-ICMS. O Apêndice II estabelece a relação da renda previdenciária decorrente do pagamento de benefícios em cada município potiguar com o FPM e o IDH-Municipal (IDH-M) do respectivo ente municipal. E o Apêndice III estabelece a relação do PIB municipal com renda previdenciária decorrente do pagamento de benefícios.

Identificou-se na pesquisa que em apenas $22(13,18 \%)$ dos 167 municípios do RN os valores transferidos pela Previdência Social aos beneficiários urbanos superam os valores pagos aos beneficiários rurais, o que permitir dizer que em $86,82 \%$ dos municípios potiguares é maior o volume de créditos previdenciários advindos da atividade rural.

Extrai-se do detalhado comparativo do Apêndice I que 51 (30,53\%) dos 167 municípios do RN têm a cota do FPM inferior ao valor proveniente do pagamento de benefícios da Previdência Social à clientela rural. E, se considerada a transferência total de renda da Previdência Social (clientela rural + urbana), temos que 65 (38,92\%) dos 167 municípios do RN têm a cota do FPM inferior a transferência de recursos provenientes da previdência.

Em que pese o número maior de municípios onde os recursos do FPM superam as transferências previdenciárias, quando se analisa a relação entre o valor total dos benefícios emitidos no estado e o valor total do FPM que é destinado aos seus municípios, constata-se uma grande disparidade de valores, equivalendo os benefícios a várias vezes o valor do FPM. Como visto, em 2009, o crédito líquido total resultante do pagamento de benefícios previdenciários nos municípios do $\mathrm{RN}$ equivale a 2,91 vezes o valor total repassado do FPM aos mesmos municípios, a corroborar que, como na maioria do país, a Previdência Social tem desempenhado um papel importante na economia dos municípios potiguares. 
A explicação para o fato do valor total da renda previdenciária superar em várias vezes o FPM, embora esta transferência fiscal seja monetariamente superior na maioria dos municípios do estado, provavelmente está na proliferação de municípios de baixa densidade populacional no estado do RN, a provocar o repasse de FPM em seu valor mínimo, o qual, ainda assim é expressivo em relação ao PIB do respectivo município.

Por exemplo, o município de Bodó, com 2.611 habitantes, recebe o mesmo repasse de FPM que o município de Carnaubais, com 9.578 habitantes. Como não existe valor mínimo de repasse da verba previdenciária, pois este é determinado pelo número de benefícios emitidos em favor dos beneficiários de cada localidade, o volume de recursos das transferências previdenciárias acaba sendo superado pelo FPM nos municípios de menor população. E, no RN, 104 dos seus 167 municípios têm população de até 10.188 habitantes, o que os coloca necessariamente na faixa mínima do FPM.

Tem-se, assim, que quanto menor a densidade populacional do município maior as chances dos repasses advindos do FPM superarem o valor líquido dos benefícios emitidos pela Previdência Social. É o que se verificou, por exemplo, nos municípios de Água Nova (2.929 habitantes), Caiçara do Rio do Vento (3.158 habitantes), Itaú (5.936 habitantes), Ipueira (2.097 habitantes), Lagoa de Velhos (2.704 habitantes), entre outros, onde a expressão monetária do pagamento de benefícios equivale a menos da metade dos repasses do FPM.

O inverso também é verdadeiro, ou seja, quanto maior a densidade populacional maior as chances dos repasses de pagamento de benefícios superarem as verbas transferidas do FPM. E a superioridade da verba previdenciária em relação ao FPM, quando ocorre, dá-se em proporções muito superiores, a exemplo do que se observou nos municípios de Açu (52.824), Mossoró (241.645) e Natal (798.065), nos quais o valor total do pagamento de benefícios da Previdência Social supera em cinco vezes o total das verbas do FPM.

De qualquer forma, os dados do Apêndice III demonstram que mesmo nos municípios onde o FPM supera a verba previdenciária, esta verba representa significativa parcela do PIB municipal, a confirmar a relevância econômica da Previdência Social para a economia local.

Ainda do garimpo dos dados coletados, viu-se que entre os 158 municípios do RN cujas transferências constitucionais foram investigadas apenas 11 deles tem receita própria 
superior a transferência de renda proveniente da previdência rural, a revelar que o subsistema de Previdência Rural supera a arrecadação de tributos próprios municipais em aproximadamente $88 \%$ dos municípios do RN.

Este dado indica a precária autonomia financeira dos municípios potiguares, cuja maquina administrativa pouco arrecada dentro de suas competências constitucionais de tributar, tornando-os ainda mais dependentes das transferências constitucionais e da renda previdenciária percebida por seus habitantes.

Outra evidência da importância da verba previdenciária rural para os municípios do $\mathrm{RN}$ decorre do fato de que no universo dos 158 municípios do RN cujas transferências constitucionais foram investigadas apenas 21 tem a COTA-ICMS superior a transferência de renda proveniente da Previdência Rural.

Quanto à repercussão social dos recursos previdenciários, os dados coletados no Apêndice II sugerem que a renda previdenciária influencia na qualidade de vida das pessoas mais positivamente que a principal transferência fiscal federal, o FPM. Isso porque os municípios potiguares melhor situados com a relação ao IDH-M apresentam a renda previdenciária decorrente do pagamento de benefícios superior aos recursos do FPM. Enquanto aqueles municípios que têm o FPM como fonte de receita principal tendem a figurar em pior classificação no IDH-M.

Nessa linha, aponta o Apêndice II que entre os 10 municípios do RN com melhor IDH-M, 7 deles têm a renda previdenciária superior às transferência do FPM. No oposto, entre os 10 municípios com pior IDH-M, todos os 10 têm as transferência do FPM superior à renda previdenciária, o que converge com os trabalhos de Sólon (2004) sobre a Previdência Social.

É provável que a relação positiva da renda previdenciária com o Índice de Desenvolvimento Humano do Município deva-se a maior focalização daquela renda em favor dos grupos de maior vulnerabilidade social, notadamente, o público-alvo do subsistema de previdência rural.

A este respeito, considerou Schwarzer (2000, p. 58) que 


\begin{abstract}
"A ampla maioria dessas pessoas beneficiadas (pela previdência rural) parece estar entre as menos abonadas do país, seja qual for o padrão de referência adotado. Nesse sentido, uma primeira conclusão a ser traçada a partir dos dados levantados neste texto é que o programa, para as dimensões que atinge, a cobertura de riscos sociais que promove e a eficiência de 'focalização' no combate à pobreza, pode ser considerado muito barato e eficiente, como talvez poucos outros consigam ser no mundo".
\end{abstract}

O próprio método de distribuição da renda previdenciária diretamente ao seu beneficiário, sem interpostos, parece influenciar em prol do resultado positivo esperado por esta política, porquanto, os recursos oriundos das transferências fiscais explícitas, a exemplo do FPM e da cota-parte do ICMS, são geridos pela autoridade pública constituída e empregados em políticas que nem sempre refletem melhoria na qualidade de vida da população local.

Nesse sentido, argumenta França $(2004,14)$ que as transferências previdenciárias "Acabam sendo mais importantes que a prefeitura, porque o recurso do FPM é, muitas vezes, diluído em políticas públicas inadequadas. E, no caso dos aposentados, eles sabem destinar muito bem os recursos para aquelas necessidades básicas deles e da comunidade". Assim, os dados convergem com outros estudos (França, 2004; Costanzi e Barbosa, 2009) que apontam que nos municípios onde os indicadores econômicos e sociais são desfavoráveis, o FPM apresenta-se em maior participação no PIB municipal. Contrario sensu, nos municípios onde os indicadores econômicos e sociais são mais favoráveis, o FPM tem menor participação no PIB, e isto indica que a Previdência Social contribui decisivamente para a geração de renda nestes municípios.

Reforçando o impacto social positivo da Previdência Social, de acordo com a PNAD 2008, no Rio Grande do Norte, em 2008, as transferências previdenciárias reduziram o contingente de pessoas vivendo abaixo da linha de pobreza (rendimento médio domiciliar per capita de até meio salário mínimo mensal) em $14,1 \%$ pontos percentuais, o que ultrapassa a média nacional que no mesmo período foi de $12,3 \%$. Trata-se do sexto maior impacto sobre a pobreza entre as unidades federativas.

A análise conjunta dos dados amealhados neste capítulo reforça a idéia de que a implantação da previdência no meio rural trouxe resultados significativos, que podem se traduzir em indicadores de impacto para a qualidade de vida da população e da economia dos municípios do RN. 


\section{CONSIDERAÇÕES FINAIS}

Este trabalho procurou ressaltar a importância da previdência rural na economia dos municípios do Rio Grande do Norte.

Para ordenar as questões referentes à previdência social como fator de desenvolvimento socioeconômico municipal, trabalhou-se, inicialmente, com capítulos teóricos com intuito de fazer uma exposição sobre o processo histórico e as influências culturais, sociais e econômicas na formação da Previdência Social enquanto política estatal de proteção social.

A partir da investigação das razões pela qual existem programas previdenciários públicos, constatou-se que pelo menos quatro razões são fundamentais para existência de sistemas organizados de Previdência Social criados por iniciativa estatal, a saber, razões de natureza econômica, social, jurídica e política, de modo que atualmente existe razoável consenso sobre a necessidade de intervenção do Estado na montagem, manutenção e fiscalização dos sistemas previdenciários.

$\mathrm{Na}$ abordagem da evolução histórica da Previdência Social, afirmou-se que, embora a solidariedade social entre as pessoas remonte as formas mais rudimentares de associação humana, somente com o enfraquecimento do ideal liberal e com o advento do denominado Estado Social que sucede o Estado Liberal é que se tem campo fértil a estruturação de um sistema previdenciário edificado como direito do cidadão e dever do Estado.

Nesse contexto, o trabalho aduziu que as medidas de proteção social previdenciária têm seu apogeu de desenvolvimento, fortalecimento e expansão no momento que sucede à Segunda Guerra. A partir desse momento desenvolve-se a caracterização do ideal de seguridade social, passando-se a compreender a previdência social como uma técnica pública, obrigatória e universal, capaz de garantir o mínimo necessário para a manutenção da dignidade do ser humano, e apta a colaborar no combate aos problemas econômicos, políticos e sociais, gerando bem-estar social. 
$\mathrm{Na}$ perspectiva do desenvolvimento da proteção social pelo Estado brasileiro, o trabalho revelou que a caracterização da realidade social nacional evidencia desequilíbrios e contrastes cuja origem e justificativa encontra-se na história mais remota da formação do Estado brasileiro, o qual, para alguns, até hoje não conseguiu estruturar-se como um verdadeiro Estado de bem-estar social.

Discorreu o estudo que as medidas de proteção securitária foram implantadas no Brasil de forma seletiva, heterogênea e fragmentada, sendo que até pouco antes da década de 1930, o Brasil não tinha articulado um sistema de proteção social previdenciária, a confirmar o silêncio sobre a questão nas primeiras Cartas de 1824 e 1891. A seletividade destacada pelos autores diz respeito ao reduzido número de beneficiários atendido pelo sistema. A heterogeneidade refere-se ao fato de algumas categorias profissionais possuírem uma gama maior de benefícios em relação a outras. A fragmentação, por sua vez diz respeito à multiplicidade de instituições, com situações financeiras e bases de arrecadação diferenciadas, que respondiam pela cobertura previdenciária da população incluída.

Destacou o estudo que, por falta de organização e articulação política, a viabilização do regime previdenciário rural acontece somente em 1971, através da Lei Complementar $n^{\circ}$ 11, a partir do Programa de Assistência ao Trabalhador Rural (PRORURAL), executado pelo Fundo de Assistência e Previdência do Trabalhador Rural (FUNRURAL). Os benefícios destes programas eras destinados aos trabalhadores rurais assalariados e autônomos do regime de economia familiar e seus dependentes.

O trabalho demonstrou que, apesar de ter representado avanço, a proteção previdenciária criada pelo PRORURAL continuava mitigada e diferenciada em relação à prevista aos demais segurados urbanos. O tratamento desigual no tocante à proteção previdenciária manteve-se até o advento da Constituição Federal de 1988, que finalmente elegeu a uniformidade e equivalência dos benefícios e serviços às populações urbanas e rurais à categoria de princípio constitucional.

Destacou-se que as novas regras instituídas pela CF de 1988 ensejaram expressivo incremento da cobertura previdenciária rural, entre os anos de 1991 a 1994, quando se verificou crescimento de aproximadamente $50 \%$ nos números de beneficiários da clientela rural. 
É preciso salientar, ainda, que foram levantados ao longo do texto informações que apontam para uma redução gradativa dos gastos com a previdência rural, devido à tendência iniciada, há poucas décadas, de redução progressiva da população rural. Este gastos tendem a diminuir também em razão da ainda lenta, mas persistente, queda do percentual de trabalhadores que não contribuem para a previdência social, em suas diversas modalidades contributivas.

A redução da clientela previdenciária rural no $\mathrm{RN}$ demonstrada no trabalho corrobora a tendência observada nacionalmente, onde se registrou a queda do percentual de segurados especiais de 10,5\%, em 2001, para 8,6\%, em 2008, da população economicamente ativa atingida pela cobertura previdenciária, esta tendência de queda está relacionada com a redução dos desocupados (pessoas sem emprego formal), tanto nas áreas urbanas quanto rurais, ao longo da década de 2000.

Quanto ao financiamento da previdência rural, defendeu o trabalho que a previdência rural como parte integrante da Previdência Social está contida na Seguridade Social, logo a receita mantedora das despesas previdenciárias do RGPS advém das mesmas fontes financiadoras da Seguridade, descritas no art. 195 da CF/88.

Nessa linha, o trabalho sustentou que, embora seja comum o estudo do financiamento da previdência rural a partir do resultado das contribuições sociais (tributos) vertidas especificamente pelos contribuintes rurais (empregadores e trabalhadores), e desta ótica invariavelmente emerge a conclusão de que o subsistema previdenciário rural é fortemente deficitário, a verdade é que o arranjo jurídico-constitucional em nenhum momento enseja esta distinção entre as fontes de custeio, as quais foram destinadas pelo constituinte originário para a cobertura da Seguridade Social como um todo, incluindo-se, portanto, indistintamente as ações de iniciativa dos Poderes Públicos e da sociedade, destinadas a assegurar os direitos relativos à saúde, à previdência e à assistência social.

Dessa forma, partindo do pressuposto que não existe déficit nas contas da Seguridade Social, sustentou o trabalho que não poderia haver déficit em seus subsistemas, entre os quais o previdenciário, seja no atendimento da clientela rural ou urbana. 
Ponderou-se que o sistema previdenciário rural só poderia ser considerado deficitário se levado em consideração para o seu custeio apenas as receitas decorrentes das contribuições vertidas pelos empregadores e trabalhadores vinculados ao setor rural. Por este prisma, a arrecadação sobre a atividade rural cobriria em torno de um décimo da despesa com os benefícios emitidos, a ensejar financiamento, a princípio pelo sistema previdenciário urbano, em percentual superior a $1 \%$ do PIB nacional.

De qualquer sorte, o trabalho chamou atenção para o fato de que o sistema previdenciário rural ser deficitário não é, em si, grave, pois o mesmo apresenta uma série de externalidades positivas que o justificam.

Afora isso, segundo Schwarzer (2000b), constatou-se que entre os casos de sistemas de aposentadorias ou outros benefícios à população rural conhecidos de outros países, não há um sequer que tenha logrado a auto-suficiência financeira, porque simplesmente o modelo bismarckiano não é capaz de se adaptar às características elementares da atividade econômica rural. Por isso, também não há como esperar que um sistema de previdência rural venha a ser autofinanciável no Brasil e deve-se ter certeza de que o programa prosseguirá exigindo transferências de recursos, seja de contribuintes previdenciários urbanos, seja a partir do Tesouro Nacional.

Nesse ponto, o trabalho filia-se ao pensamento de Schwarzer (2000b) quando afirma que a última fonte parece tecnicamente a mais adequada, uma vez que subsidiar o segurado especial rural com recursos de contribuição urbana fará com que os benefícios urbanos percam em qualidade atuarial e tornem-se crescentemente desinteressantes aos segurados normais, minando a sustentabilidade política de longo prazo do sistema previdenciário como um todo. E filia-se também a proposta de Delgado (1999) de criar uma contribuição previdenciária simbólica a ser recolhida pelo segurado especial como fonte de custeio subsidiária das despesas geradas pelos benefícios que lhe são destinados.

No capítulo final, o estudo abordou a origem do federalismo no Brasil, relacionando a isso nossa tradição centralizadora no que pertine a distribuição das receitas tributárias. Nesse trilhar, demonstrou-se que mesmo com o advento da Constituição de 1988, que pretedeu avançar para um federalismo menos centralizado e de três níveis (incluindo uma terceira esfera de poder político: o município), o número de competências e recursos tributários 
destinados à União em detrimento dos estados e municípios é muito grande, fazendo com que se tenha um modelo federativo ainda marcadamente centralizador.

Entre os efeitos desta centralização está que as transferências constitucionais federais e estaduais ainda representam a principal fonte de receita fiscal da maioria dos municípios brasileiros.

A pesquisa abordou ainda estudos que têm enfatizado o impacto da Previdência Social sobre a economia local de pequenos municípios, para em seguida cruzar dados e estatísticas com o propósito de dimensionar a relevância socioeconômica da renda previdenciária rural nos municípios do Rio Grande do Norte. Para este fim, estabeleceu-se a comparação do valor monetário transferido a cada um dos 167 municípios do RN pelo pagamento dos benefícios previdenciários - rurais e urbanos - com as fontes de recurso igualmente importantes no orçamento destes entes municipais. Além das receitas tributárias próprias, constituíram objeto de análise comparativa com o valor dos benefícios previdenciários emitidos no $\mathrm{RN}$, a transferência estadual referentes a cota parte do município sobre o ICMS e a transferência federal relativa ao FPM.

A coleta de dados permitiu confirmar que, a exemplo do que ocorre em outros estados, a Previdência Social vem exercendo uma forte influência na economia dos municípios do RN, de forma que os pagamentos de benefícios superam os do FPM e da cota-parte do ICMS, representando considerável parte do PIB destes municípios, com repercussão positiva no combate a pobreza e na melhoria do bem-estar da população.

Dos dados coletados contatou-se que, na década de 2000, o RN recebeu sistematicamente transferências previdenciárias em quantidade monetária muito superior aos respectivos valores da arrecadação previdenciária no estado. De 2002 a 2007, o RN arrecadou contribuições previdenciárias entre 3,3\% a 4,2\% de seu PIB e, em contrapartida, no mesmo período, recebeu a título de crédito de pagamentos de benefícios em valores que variaram entre $9,3 \%$ a $10,3 \%$ do seu PIB, resultando em favor dos municípios potiguares ganho monetário proporcional a $5,79 \%$ a $6,58 \%$ de toda riqueza produzida no estado.

O superávit na relação pagamento de benefício e a correspectiva arrecadação previdenciária coloca o $\mathrm{RN}$ entre os estados beneficiados pelo efeito redistributivo inter- 
regional da Previdência Social, pois arrecada contribuições sociais vinculadas tradicionalmente à despesa previdenciária em proporção significativamente inferior ao que paga em benefícios.

Identificou-se na pesquisa que apenas em 22 dos 167 municípios do RN os valores transferidos pela Previdência Social à clientela urbana superam os valores transferidos à clientela rural, o que permitir dizer que em $86,82 \%$ dos municípios do $\mathrm{RN}$ a soma dos valores dos benefícios emitidos à clientela rural é maior que a soma dos valores dos benefícios destinados à clientela urbana.

Ainda do garimpo dos dados coletados, viu-se que entre os 158 municípios do RN cujas transferências constitucionais foram investigadas apenas 11 deles tem receita própria superior a transferência de renda proveniente da previdência rural, a revelar que o subsistema de Previdência Rural supera a arrecadação de tributos próprios municipais em aproximadamente $88 \%$ dos municípios do $\mathrm{RN}$.

Outra evidência da importância da verba previdenciária rural para os municípios do RN decorre do fato de que no universo dos 158 municípios do RN cujas transferências constitucionais foram investigadas apenas 21 tem a COTA-ICMS superior a transferência de renda proveniente da Previdência Rural.

Quanto à repercussão social dos recursos previdenciários, verificou-se que a renda previdenciária influencia na qualidade de vida das pessoas mais positivamente que a principal transferência fiscal federal repassa aos municípios, o FPM. Esta influência é sugerida pelo fato dos municípios potiguares melhor situados com a relação ao IDH-M apresentarem a renda previdenciária decorrente do pagamento de benefícios superior aos recursos do FPM. Enquanto aqueles municípios que têm o FPM como fonte de receita principal tendem a figurar em pior classificação no IDH-M.

Nessa linha, a pesquisa apontou que entre os 10 municípios do RN com melhor IDHM, 7 deles têm a renda previdenciária superior às transferência do FPM. No oposto, entre os 10 municípios com pior IDH-M, todos os 10 têm as transferência do FPM superior à renda previdenciária, o que converge com os trabalhos de França (2004) sobre a Previdência Social. 
O estudo cogitou que a relação positiva da renda previdenciária com o Índice de Desenvolvimento Humano do Município deva-se a maior focalização daquela renda em favor dos grupos de maior vulnerabilidade social, notadamente, o público-alvo do subsistema de previdência rural. O próprio método de distribuição da renda previdenciária diretamente ao seu beneficiário, sem interpostos, influencia em prol do resultado positivo esperado por esta política, porquanto, os recursos oriundos das transferências fiscais explícitas, a exemplo do FPM e da cota-parte do ICMS, são geridos pela autoridade pública constituída e empregados em políticas que nem sempre refletem melhoria na qualidade de vida da população local.

Assim, os dados convergem com outros estudos cujas conclusões apontam que nos municípios onde os indicadores econômicos e sociais são desfavoráveis, o FPM apresenta-se em maior participação no PIB municipal. Contrario sensu, nos municípios onde os indicadores econômicos e sociais são mais favoráveis, o FPM tem menor participação no PIB, e isto indica que a Previdência Social contribui decisivamente para a geração de renda nestes municípios.

Reforçando o impacto social positivo da Previdência Social, a pesquisa constatou que, no Rio Grande do Norte, as transferências previdenciárias reduzem o contingente de pessoas vivendo abaixo da linha de pobreza em $14,1 \%$, proporção superior à média nacional que é de 12,3\%. Esse dado o coloca na posição de sexta maior redução entre os estados brasileiros.

O resultado da pesquisa reforça a idéia de que a implantação da previdência no meio rural trouxe resultados significativos, que podem se traduzir em indicadores de impacto para a qualidade de vida da população e da economia dos municípios do RN. Os dados e argumentos apresentados revelaram que o montante de recursos que é introduzido nos municípios do RN pela Previdência Social supera as receitas municipais próprias, o Fundo de Participação dos Municípios (FPM) e os recursos da COTA-ICMS. Nesse sentido, a hipótese converge com os estudos de amplitude geral que afirmam que a Previdência Social Rural oferece uma considerável contribuição para o desenvolvimento das economias locais e para a elevação da qualidade de vida da população. 


\section{REFERÊNCIAS BIBLIOGRÁFICAS.}

AQUINO, Joacir Rufino de; SOUZA, Ronie Cléber de. Impactos Socioeconômicos da Previdência Rural no Brasil: um estudo de caso no município de Encanto/RN. Disponível em: http://www.sober.org.br/palestra/6/663.pdf. Acesso em: 04 de jun de 2010.

ANFIP - Associação Nacional dos Auditores Fiscais da Receita Federal do Brasil. Análise da Seguridade Social em 2006. Brasília: ANFIP, 2007.

20 anos da Constituição Cidadã: avaliação e desafios da Seguridade Social. Flavio Tonelli Vaz, Juliano Sander Musse, Rodolfo Fonseca dos Santos (Coords.). Brasília : ANFIP, 2008.

ARAÚJO, Odília Sousa. A reforma da Previdência Social brasileira no contexto das reformas do Estado: 1988 a 1998. Natal: EDUFRN-Editora da UFRN, 2004.

ARRETCHE, Marta. Políticas Sociais no Brasil: Descentralização em um Estado Federativo. Revista Brasileira de Ciências Sociais, São Paulo, v. 14, n. 40, pp. 111-141, 1999.

AURELIANO, Liliana; DRAIBE, Sônia Miriam. (1989). A especificidade do Welfare State brasileiro. In: MPAS/CEPAL. Economia e desenvolvimento - vol. I: reflexões sobre a natureza do bem-estar. Brasília: MPAS/ CEPAL, pp. 85-178, 1989.

BALERA, Wagner. A Seguridade Social na Constituição de 1988. São Paulo: RT, 1989.

BARBOSA, Rômulo Soares. Entre a Igualdade e a Diferença: processos sociais e disputas políticas em torno da Previdência Social no Brasil. Tese de Doutorado - Seropédica, UFRRJ, 2007.

BARROS JUNIOR, Cássio Mesquita. Previdência Social Urbana e Rural, São Paulo: Saraiva, 1981.

BATISTA, A. S. et al. Envelhecimento e dependência: desafios para a organização da proteção social. Brasília: MPS, 2008.

BELTRÃO, Kaizô Iwakami; CAMARANO, Ana Amélia; MELlO, Juliana Leitão e. Mudanças nas Condições de Vida dos Idosos Rurais Brasileiros: Resultados NãoEsperados dos Avanços da Seguridade Social. Brasília: IPEA, 2005. Texto para Discussão, n. ${ }^{\circ} 1282$. 
BELTRÃO, Kaizô Iwakami; OLIVEIRA, Francisco Eduardo Barreto de; PINHEIRO, Sonôe Sugahara. A população rural e a Previdência Social no brasil: uma análise com ênfase nas mudanças constitucionais. Brasília: IPEA, 2000. Texto para Discussão, n. ${ }^{\circ} 759$.

BERWANGER, Jane Lucia W. Previdência Rural: inclusão social. $2^{a}$ ed., Curitiba: Juruá, 2008 .

BOSCHETTI, Ivanete. Seguridade Social e trabalho: paradoxos na construção das políticas de previdência e assistência social no Brasil. Brasília: Letras Livres; Ed. UNB, 2006.

BRASIL. Constituição (1988). Constituição da República Federativa do Brasil. Brasília, DF, Senado, 1988.

BREMAEKER, François E. J. de. A Construção de um Pacto federativo que Interesse a todos os Municípios. IBAM/ENSUR/CEIF/IBAMCO (Série Estudos Especiais n.o 194), 2007.

CAETANO, Marcelo Abi-Ramia. Determinantes da Sustentabilidade e do Custo Previdenciário: Aspectos Conceituais e Comparações Internacionais. Brasília: IPEA, 2006. Texto para Discussão, n. ${ }^{\circ} 1226$.

. Previdência Social e Distribuição Regional da Renda. Brasília: IPEA, 2008. Texto para Discussão, n. ${ }^{\circ} 1318$.

CAETANO, Marcelo Abi-Ramia; ROCHA, Roberto de Rezende Rocha. O sistema previdenciário brasileiro: uma avaliação de desempenho comparada. Brasília: IPEA, 2008. Texto para Discussão, n. ${ }^{\circ} 1331$.

CALSAVARA, Rogério Pereira. A Previdência Social como fator de desenvolvimento socioeconômico dos municípios brasileiro. Campinas, 2001. Mimeo.

CAMPOS, André. Aspectos da proposta de mudança na regulamentação da previdência rural no Brasil. Brasília: IPEA, 2006. Texto para Discussão, n. ${ }^{\circ} 1195$.

CARVAlHO, José Murilo de. Cidadania no Brasil: o longo caminho. 11. ed. Rio de Janeiro: Civilização Brasileira, 2008. 
CASTEL, Robert. As metamorfoses da questão social: uma crônica do salário. 4. ed. São Paulo: Vozes, 2003.

CASTRO, Carlos Alberto Pereira de; LAZZARI. João Batista. Manual de Direito Previdenciário. 9a edição. São Paulo: Ltr, 2008.

CASTRO, Jorge Abrahão de; CARDOSO JR., José Celso. Políticas sociais no Brasil: evolução do gasto social federal no período 1995/2002. In: JACCOUD, L. (Org.). Questão social e políticas sociais no Brasil contemporâneo. Brasília: Ipea, 2005.

COSTANZI, Rogério Nagamine; ANSILIERO, Graziela. Considerações sobre a Política de Reajuste de Benefícios da Previdência Social e Comparações com Índices de Inflação. In Estudos e Pesquisas da Secretaria de Políticas de Previdência Social 2003-2009. (Coleção Previdência Social, Série Estudos; v. 31, 1. Ed.). Brasília: MPS, abril, pp. 181-198, 2009.

COSTANZI, Rogério Nagamine; BARBOSA, Edvaldo Duarte. A Previdência Social e a Distribuição de Renda Intermunicipal. In Estudos e Pesquisas da Secretaria de Políticas de Previdência Social 2003-2009. (Coleção Previdência Social, Série Estudos; v. 31, 1. Ed.). Brasília: MPS, abril, pp. 94-111, 2009.

CORDEIRO, Marcel. Previdência Social Rural. Campinas: Ed. Millennium, 2008.

DAVID, M. D. ; DAVID, A. C. A. ; RODRIGUES, M. S ; ROLLO, P. A.. Previdência Rural no Brasil: uma análise de seu impacto e eficácia como instrumento de combate à pobreza rural. In: Anais do Seminário Fao/Cepal/Rimisp: Experiências Exitosas de Combate à Pobreza Rural na América Latina, Ago/set, 1999.

DELGADO, Guilherme C.. Previdência rural: relatório de avaliação socioeconômica. Brasília: IPEA, 1997 (texto para discussão, 477).

DELGADO, Guilherme C. . Experiências exitosas de combate a pobreza rural: lições para a reorientação de políticas. Caso Brasil: sistema de previdência social rural. Brasília: FAO, 1999. (Projeto FAO Pobreza - LOA 98290/RLC).

DELGADO, Guilherme C.; CARDOSO Jr., José Celso. O idoso e a previdência rural no Brasil: a experiência recente de universalização. Brasília: IPEA, 1999. (texto para discussão, 688).

DELGADO, Guilherme C.; CARDOSO Jr., José Celso. Principais resultados da pesquisa domiciliar sobre a previdência rural na região sul do Brasil (Projeto Avaliação 
Socioeconômica da Previdência Social Rural). Rio de Janeiro: IPEA, 2000 (texto para discussão, 734).

DELGADO, Guilherme C.; CARDOSO Jr., José C. (orgs.) Universalização de Direitos Sociais no Brasil: a experiência da previdência rural nos anos 90. Brasília, Rio de Janeiro: IPEA, ago. 2000.

DELGADO, Guilherme C.; CASTRO, Jorge Abrahão de; Financiamento da Previdência Rural: Situação Atual e Mudanças. Brasília: IPEA, 2003. (Texto para Discussão, n. ${ }^{\circ}$ 992).

DELGADO, Guilherme C.; SCHWARZER, Helmut. Evolução histórico-legal e formas de financiamento da previdência rural no Brasil. In: Guilherme Delgado e José Celso Cardoso Jr. (orgs.), A universalização de direitos sociais no Brasil: a Previdência Rural nos anos 90, Brasília: IPEA, 2000, p.187-210.

DRAIBE, Sônia Miriam. O Welfare state no Brasil: características e perspectivas. Caderno de Pesquisas n. 08. Campinas: UNICAMP, 1993.

DRAIBE, S. M., CASTRO, M.H.G., AZEVEDO, B. O sistema de proteção social no Brasil. Campinas: NEPP/UNICAMP, 1991.

ESPING-ANDERSEN, Gosta. As três economias políticas do Welfare State. Lua Nova, n.24, p. 85-116, set. 1991.

FAGNANI, Eduardo. Política Social no Brasil (1964-2002): entre a cidadania e a caridade. Tese (Doutorado) - UNICAMP, Campinas, 2005 (mimeo).

Direitos sociais no fio da navalha. In 20 anos da Constituição Cidadã: avaliação e desafios da Seguridade Social. Flavio Tonelli Vaz, Juliano Sander Musse, Rodolfo Fonseca dos Santos (Coords.). Brasília : ANFIP, pp. 23-44, 2008.

FALEIROS. Vicente de Paula. A Política Social do Estado Capitalista: as funções da previdência e da assistência social. São Paulo: Cortez, 2000.

FARIA, Carlos Aurélio Pimenta de. Uma Genealogia das Teorias e Tipologias do Estado de Bem-Estar Social. In: O Estado de Bem-Estar Social no Século XXI/ Maurício Godinho Delgado, Lorena Vasconcelos Porto (orgs.). São Paulo: LTr, pp. 31-86, 2007.

FIGUEIREDO, Marcus Faria; FIGUEIREDO, Argelina M. Cheibub. Avaliação política e avaliação de políticas: um quadro de referência teórica. Análise e Conjuntura, São Paulo, v. 1, n. 3, p. set./dez., pp. 107-127, 1986. 
FORTES, Simone Barbisan. Previdência Social no Estado Democrático de Direito: uma visão à luz da teoria da justiça. São Paulo: Ltr, 2005.

FRANÇA, Álvaro Sólon de. Previdência Social e a Economia dos Municípios. $5^{\mathrm{a}}$ ed., Brasília: ANFIP, 2004.

GALINDO, Osmil; Irmão, José Ferreira. A Previdência Rural e a Recuperação Econômica e Social das Famílias do Nordeste. In: Guilherme Delgado e José Celso Cardoso Jr. (orgs.), A universalização de direitos sociais no Brasil: a Previdência Rural nos anos 90, $2^{\mathrm{a}}$ ed., Brasília: IPEA, p.165-186, 2003.

GENTIL, Denise. A Política Fiscal e a Falsa Crise da Seguridade Social Brasileira Análise financeira do período 1990-2005. Rio de Janeiro, Tese de Doutoramento, Instituto de Economia/UFRJ, 2006 (mimeo).

GIAMBIAGE, Fabio; TAFNER, Paulo (organizadores). Previdência no Brasil: debates, dilemas e escolhas. Rio de Janeiro: IPEA, 2007.

GIAMBIAGI, Fabio. et al. Diagnóstico da Previdência Social no Brasil: o que foi feito e o que falta reformar? Revista Pesquisa e Planejamento Econômico - PPE. Volume 34, número 3. Brasília: IPEA, Dezembro /2004.

Reforma da Previdência: O Encontro Marcado. $1^{a}$ edição. Rio de Janeiro: Elsevier, 2007.

GODINHO DELGADO, Ignácio. Previdência Social e mercado no Brasil. São Paulo: LTr, 2001.

GOLDANI, Ana Maria. Relações intergeracionais e reconstrução do Estado de BemEstar. Por que se deve repensar essa relação para o Brasil? In: CAMARANO, Ana Amélia. Os novos idosos brasileiros: muito além dos 60? Rio de Janeiro: IPEA/IBGE, 2004. HOBSBAWN, Eric. A era dos extremos: o breve século XX: 1941-1991. São Paulo: Companhia das Letras, 1995.

IBGE, Instituto Brasileiro de Geografia e Estatística. Censo Demográfico-Brasil. Rio de Janeiro: IBGE, 2000. 
2008.

Pesquisa Nacional por Amostra de Domicílios (PNAD). Microdados, 2006, 2007 e

. Síntese de Pesquisas. Informativo para Imprensa. Natal: IBGE, 2010. Disponível em http://www.ibge.gov.br/home/estatistica/pesquisas/default.shtm. Acesso em: 16 de ago. de 2010.

IDEMA, Instituto de Defesa do Meio Ambiente do Rio Grande do Norte. Anuário Estatístico do Rio Grande do Norte - 2007. Disponível em: http://www.idema.rn.gov.br/contentproducao/aplicacao/idema/anuario/enviados/anuario_estat istico.asp. Acesso em: 26 de ago. de 2010.

IPEA, Instituto de Pesquisas Econômicas Aplicadas. Brasil: o Estado de uma Nação. Brasília: IPEA, 2007.

PNAD 2008: Primeiras análises - Demografia, Trabalho e previdência. Comunicado n. ${ }^{\text {3 } 31 . ~ B r a s i ́ l i a: ~ I P E A, ~ 2009 a . ~}$

Políticas Sociais: acompanhamento e análise n⿳ 17 - Introdução. Edição especial: Vinte anos da Constituição Federal. Brasília: IPEA, 2009b.

Políticas Sociais: acompanhamento e análise $n^{\circ} 17$ - Volume 1. Edição especial: Vinte anos da Constituição Federal. Brasília: IPEA, 2009c.

PNAD 2008: Primeiras análises - O setor rural. Comunicado n. ${ }^{\circ}$ 42. Brasília: IPEA, 2010a.

Dimensão, evolução e projeção da pobreza por região e por estado no Brasil. Comunicado n. ${ }^{\circ}$ 58. Brasília: IPEA, 2010 b.

Previdência e Assistência Social: Efeitos no Rendimento Familiar e sua Dimensão nos Estados. Comunicado n. ${ }^{\circ}$ 59. Brasília: IPEA, 2010c.

JUNIOR, Roberto de Goes Ellery; BUGARIN, Mirta N. S.. Previdência Social e Bem-Estar no Brasil. Brasília: IPEA, 2001 (Texto para Discussão, n. ${ }^{\circ} 831$ ).

KERBAUY, Luís Rodrigues. A previdência na área rural: benefício e custeio. Dissertação (Mestrado em Direito) - Pontifícia Universidade Católica de São Paulo, São Paulo. 2008 (mimeo.) 
KING, Desmond S. O Estado e as estruturas sociais de bem-estar em democracias industriais avançadas. Revista Novos Estudos, CEBRAP, n.22, outubro, 1988.

LOWI, Theodore j. American Business, Public Policy, Casa-Studies, and Political Theory. World Politics. Vol. 16, n. 4, pp. 691-693, 1964.

MALLOY, James M. A política de previdência social no Brasil. Rio de Janeiro: Graal, 1986.

. Authoritarianism and the extension of social security protection to the rural sector in Brazil. Pittsburgh, 1976.

MARQUES, Rosa Maria, et al. A Previdência Social no Brasil. $1^{\text {a }}$ edição. São Paulo: Editora Fundação Perseu Abramo, 2003.

MEDEIROS, Marcelo. A Trajetória do Welfare State no Brasil: papel redistributivo das políticas sociais dos anos 1930 aos anos 1990. Brasília: IPEA, 2001. (Texto para discussão n. $\left.{ }^{\circ} 852\right)$.

MPS, Ministério da Previdência Social. Anuário Estatístico da Previdência Social - AEPS. Brasília: Dataprev, 1993 a 2008.

2009.

Boletim Estatístico da Previdência Social - Nordeste - Julho/2009. Brasília,

Estatísticas Municipais de Previdência Social. Brasília, MPAS/GM, 2000 a 2009.

. Fórum Nacional da Previdência Social. Síntese das Atividades Desenvolvidas. Brasília, 2007.

Informe de Previdência Social. Volume 21, número 12. Brasília, 2009.

Panorama da Previdência Social Brasileira. Brasília, março/2004.

Livro Branco da Previdência Social. Brasília, MPAS/GM, 2002.

MIRANDA, Rogério Boueri; CAETANO, Marcelo Abi-Ramia. Comparativo Internacional para a Previdência Internacional. Brasília: IPEA, 2007. (Texto para Discussão, n. ${ }^{\circ}$ 1302). 
MOURA, Rodrigo Leandro de; TAFNER, Paulo; FILHO, Jaime de Jesus. Testando a Propriedade Redistributiva do Sistema Previdenciário Brasileiro. Brasília: IPEA, 2007. (Texto para Discussão, n. ${ }^{\circ} 1282$ ).

NETTO, Juliana Presotto Pereira. A Previdência Social em reforma: o desafio da inclusão de um maior número de trabalhadores. São Paulo: Ltr, 2002.

NEVES, Ilídio das. Direito da Segurança Social - Princípios fundamentais numa análise prospectiva. Coimbra: Coimbra Editora, 1996.

OLIVEIRA, Maria Marly de. Como fazer projetos, relatórios, monografias, dissertações e teses. $4^{\mathrm{a}}$ ed., Rio de janeiro: Elsevier, 2008

OIT, Organização Internacional do trabalho. Convenção n. ${ }^{\circ}$ 102. Dispõe sobre normas mínimas de Seguridade Social. Genebra, 1952. Disponível em: http://www.ilo.org/public/portugue/region/ampro/brasilia/info/download/convencao102.pdf.

Acesso em: 17 de ago. de 2010.

PEREIRA JÚNIOR, Aécio. Evolução histórica da Previdência Social e os direitos fundamentais. Jus Navigandi, Teresina, ano 9, n. 707, 12 jun. 2005. Disponível em: http://jus2.uol.com.br/doutrina/texto.asp?id=6881. Acesso em: 10 de janeiro de 2009.

POCHMANN, Márcio. Gastos sociais, distribuição de renda e cidadania: uma questão política. Econômica, v. 5, n. 1, 2003.

POCHMANN, Marcio e AMORIM, Ricardo (orgs.). Atlas da exclusão social no Brasil. São Paulo: Cortez, 2003.

RAMOS, Daniela Peixoto. A Justiça Distributiva Liberal e a Previdência Social no Brasil. Brasília: IPEA, 2003. (Texto para Discussão, n. ${ }^{\circ}$ 937).

RAMOS, Lizelia Tissiani. A Previdência Pública como instrumento de inclusão para o desenvolvimento com cidadania. Dissertação - Universidade Regional do Noroeste do Estado do Rio Grande do Sul - UNIJUÍ, Ijuí, 2006 (mimeo.).

RANGEL, Leonardo Alves et al. Conquistas, desafios e perspectivas da Previdência Social no Brasil vinte anos após a promulgação a Constituição Federal de 1988. In Políticas 
Sociais: acompanhamento e análise $\mathrm{n}^{\mathrm{o}} 17$ - volume 1. Edição especial: Vinte anos da Constituição Federal. Brasília: IPEA, 2009.

ROSANVALLON, P. A crise do Estado-providência. Brasília: ed. UNB, 1997.

ROCHA, Daniel Machado. O Direito Fundamental à Previdência Social na perspectiva dos princípios constitucionais diretivos do sistema previdenciário brasileiro. Porto Alegre: Livraria do Advogado, 2004.

RODRIGUES DOS SANTOS, Jefferson. Previdência rural e suas interações com a realidade local: impactos territoriais em São José do Norte - RS. Porto Alegre: UFRGS, 2006.

RUSSOMANO, Mozart Victor. Curso de Previdência Social. $3^{\mathrm{a}}$ ed., Rio de Janeiro: Forense. 1988.

SANTOS, Wanderley Guilherme dos. Cidadania e justiça: a política social na ordem brasileira. 2. ed. Rio: Campus, 1987.

SCHWARZER, Helmut. COSTANZI, Rogério Nagamine. Globalização e Distribuição de Renda: a Importância da Previdência Rural e dos Benefícios de Prestação Continuada no Brasil. In Estudos e Pesquisas da Secretaria de Políticas de Previdência Social 2003-2009. (Coleção Previdência Social, Série Estudos; v. 31, 1. Ed.). Brasília: MPS, abril, pp. 163-180, 2009.

SCHWARZER, Helmut. Impactos Socioeconômicos do Sistema de Aposentadorias Rurais no Brasil: evidências empíricas de um estudo de caso no Estado do Pará. Brasília: IPEA, 2000a. (Texto de discussão n. ${ }^{\circ}$ 729)

- Paradigmas de Previdência Social Rural: Um panorama da Experiência internacional. Brasília, 2000b. (Texto para discussão $n^{\circ}$ 767).

SEN, Amartya. Desenvolvimento como liberdade. São Paulo: Companhia das Letras, 2000.

SOUZA, Lincoln Moraes. Comentando as classificações de políticas públicas. 2010. (mimeo).

SOUZA, Marcelo Medeiros Coelho. A Transposição de Teorias sobre o Welfare State para o caso dos Países Subdesenvolvidos. Rio de Janeiro: IPEA, 1999 (Texto para discussão n. ${ }^{\circ}$ $695)$. 
TEIXEIRA, Aloísio. Prefácio. In: ARAÚJO, Odília Sousa de. A Reforma da Previdência Social Brasileira no contexto das reformas do Estado: 1988 a 1998. Natal, EDUFRN, Editora da UFRN, 2004.

THOMPSON, Lawrence H. Mais Velha e Mais Sábia: a economia dos sistemas previdenciários. Coleção Previdência Social. Série Debates. Brasília, 2000.

TORRES, Julio Cesar. O SUAS (Sistema Único de Assistência Social) e a universalização da renda social mínima no Brasil: caminhos para uma reforma da Seguridade Social. Tese (Doutorado em Sociologia) - Universidade Estadual Paulista, Faculdade de Ciências e Letras, Campus de Araraquara, 2006.

VIANNA, Maria Lucia T. Werneck. A americanização (perversa) da Seguridade Social no Brasil: estratégias de bem-estar e políticas públicas. Rio de Janeiro: Revan: UCAM, IUPERJ, 1998. 


\section{APÊNDICE I}

Comparativo da Receita Municipal Própria, das transferênCias

CONSTITUCIONAIS (FPM E ICMS) E DO VALOR DOS BENEFÍCIOS EMITIDOS, POR

MuNicíPIO do Rio Grande do NORTE - 2008 


\begin{tabular}{|c|c|c|c|c|c|c|c|c|}
\hline $\begin{array}{l}\text { Município } \\
\text { (A) }\end{array}$ & População (B) & $\begin{array}{l}\text { Receita } \\
\text { Orçamentária } \\
\text { Total (C) em R\$ }\end{array}$ & $\begin{array}{l}\text { Receita } \\
\text { Tributária } \\
\text { Própria (D) } \\
\text { em R\$ }\end{array}$ & $\begin{array}{l}\text { FPM (E) em } \\
\text { R\$ }\end{array}$ & $\begin{array}{l}\text { Cota ICMS } \\
\text { (F) em mil } \\
\text { R\$ }\end{array}$ & $\begin{array}{l}\text { Benefícios } \\
\text { RURAIS } \\
\text { Emitidos } \\
\text { no RN } \\
\text { (G) em R\$ }\end{array}$ & $\begin{array}{l}\text { Benefícios } \\
\text { URBANOS } \\
\text { Emitidos no } \\
\text { RN } \\
\text { (H) em R\$ }\end{array}$ & $\begin{array}{l}\text { Valor Total } \\
\text { dos Benefícios } \\
\text { Emitidos no } \\
\text { RN (RURAL } \\
+ \text { URBANO) } \\
\quad \text { (I) em R\$ }\end{array}$ \\
\hline Acari & 11.222 & 11.518 .186 & 344.296 & 5.123 .969 & 918.428 & 4.519 .882 & 5.670 .629 & 10.190 .511 \\
\hline Açu & 52.824 & 45.240 .538 & 5.655 .589 & 14.090 .916 & 5.119 .290 & 42.310 .222 & 30.029 .364 & 72.339 .586 \\
\hline Afonso Bezerra & 10.628 & 11.212 .516 & 304.712 & 5.123 .969 & 628.430 & 5.778 .987 & 2.144 .393 & 7.923 .380 \\
\hline Água Nova & 2.929 & 5.872 .826 & 130.810 & 3.842 .977 & 415.118 & 1.509 .114 & 375.906 & 1.885 .019 \\
\hline Alexandria & 14.127 & 17.077 .710 & 389.380 & 6.404 .962 & 752.031 & 15.729 .015 & 4.880 .903 & 20.609 .919 \\
\hline Almino Afonso & 5.087 & 7.578 .710 & 299.196 & 3.842 .977 & 508.947 & 2.983 .239 & 553.318 & 3.536 .557 \\
\hline Alto do Rodrigues & 11.817 & 25.883 .055 & 6.575 .451 & 5.123 .969 & 4.820 .958 & 1.905 .680 & 2.469 .768 & 4.375 .447 \\
\hline Angicos & 11.544 & 11.460 .041 & 306.437 & 5.123 .969 & 854.208 & 5.651 .734 & 4.833 .511 & 10.485 .245 \\
\hline Antônio Martins & 7.205 & 11.587 .843 & 969.369 & 3.842 .977 & 506.445 & 4.909 .369 & 1.252 .653 & 6.162 .022 \\
\hline Apodi & 35.648 & 30.168 .709 & 2.797 .666 & 10.247 .939 & 3.476 .857 & 26.316 .464 & 8.422 .996 & 34.739 .460 \\
\hline Areia Branca & 25.147 & 39.152 .877 & 3.960 .723 & 8.966 .946 & 10.455 .499 & 4.353 .243 & 36.601 .594 & 40.954 .837 \\
\hline Ares & 12.611 & 19.496 .405 & 959.341 & 5.123 .969 & 6.701 .844 & 3.068 .989 & 874.970 & 3.943 .959 \\
\hline Augusto Severo & 9.194 & 10.089 .140 & 261.314 & 3.842 .977 & 599.963 & 11.232 .368 & 3.138 .854 & 14.371 .222 \\
\hline Baía Formosa & 8.726 & 14.058 .949 & 459.919 & 3.842 .977 & 6.399 .113 & 1.496 .804 & 641.496 & 2.138 .301 \\
\hline Baraúna & 23.860 & 21.811 .126 & 795.866 & 7.685 .954 & 2.468 .384 & 9.372 .990 & 3.279 .096 & 12.652 .087 \\
\hline Barcelona & 4.040 & 6.506 .097 & 131.506 & 3.842 .977 & 461.316 & 2.000 .941 & 361.321 & 2.362 .262 \\
\hline Bento Fernandes* & 5505 & 5.987 .100 & 154.400 & 3.842 .977 & 410.300 & 1.769 .108 & 193.458 & 1.962 .567 \\
\hline Bodó & 2.611 & 6.958 .202 & 100.536 & 3.842 .977 & 406.014 & 276.516 & 96.152 & 372.667 \\
\hline Bom Jesus & 8.721 & 9.848 .003 & 232.799 & 3.842 .977 & 792.609 & 3.862 .061 & 806.943 & 4.669 .004 \\
\hline Brejinho & 11.476 & 12.558 .265 & 149.800 & 5.123 .969 & 679.262 & 3.046 .245 & 593.688 & 3.639 .933 \\
\hline Caiçara do Norte* & 6.393 & 6.237 .400 & 61.100 & 3.842 .977 & 437.500 & 315.738 & 136.330 & 452.068 \\
\hline $\begin{array}{l}\text { Caiçara do Rio do } \\
\text { Vento }\end{array}$ & 3.158 & 6.760 .936 & 166.095 & 3.842 .977 & 436.160 & 1.284 .223 & 196.735 & 1.480 .958 \\
\hline Caicó & 62.497 & 51.026 .369 & 3.839 .735 & 14.090 .916 & 5.855 .170 & 30.874 .541 & 38.563 .962 & 69.438 .503 \\
\hline Campo Redondo & 10.793 & 10.005 .697 & 284.968 & 5.123 .969 & 579.487 & 5.749 .150 & 963.439 & 6.712 .589 \\
\hline Canguaretama & 30.237 & 31.539 .310 & 1.850 .410 & 8.966 .946 & 5.054 .642 & 9.875 .871 & 10.030 .015 & 19.905 .885 \\
\hline Caraúbas & 20.333 & 23.445 .697 & 1.328 .608 & 7.685 .954 & 1.851 .658 & 17.502 .551 & 5.207 .331 & 22.709 .881 \\
\hline $\begin{array}{l}\text { Carnaúba dos } \\
\text { Dantas }\end{array}$ & 7.041 & 7.986 .832 & 133.187 & 3.842 .977 & 889.265 & 2.603 .276 & 1.013 .183 & 3.616 .459 \\
\hline Carnaubais & 9.578 & 13.902 .176 & 2.104 .973 & 3.842 .977 & 2.049 .666 & 1.050 .823 & 577.447 & 1.628 .269 \\
\hline
\end{tabular}




\begin{tabular}{|c|c|c|c|c|c|c|c|c|}
\hline Ceará-Mirim & 67.416 & 60.518 .685 & 5.244 .352 & 15.371 .908 & 3.927 .408 & 29.339 .215 & 21.154 .691 & 50.493 .906 \\
\hline Cerro Corá & 11.207 & 12.878 .931 & 221.879 & 5.123 .969 & 698.935 & 5.794 .308 & 911.853 & 6.706 .161 \\
\hline $\begin{array}{l}\text { Coronel } \\
\text { Ezequiel* }\end{array}$ & 5.280 & 6.422 .200 & 165.800 & 3.842 .977 & 385.500 & 3.003 .570 & 272.371 & 3.275 .941 \\
\hline $\begin{array}{l}\text { Coronel João } \\
\text { Pessoa }\end{array}$ & 4.970 & 7.864 .081 & 111.366 & 3.842 .977 & 457.642 & 2.255 .516 & 604.129 & 2.859 .645 \\
\hline Cruzeta & 8.046 & 7.888 .598 & 188.153 & 3.842 .977 & 805.898 & 3.127 .429 & 1.056 .131 & 4.183 .560 \\
\hline Currais Novos & 43.315 & 35.618 .725 & 2.025 .839 & 11.528 .931 & 4.519 .847 & 28.169 .152 & 31.814 .537 & 59.983 .688 \\
\hline Doutor Severiano & 6.615 & 8.541 .709 & 223.253 & 3.842 .977 & 508.684 & 3.463 .630 & 888.880 & 4.352 .510 \\
\hline Encanto & 5.316 & 7.926 .287 & 175.981 & 3.842 .977 & 479.741 & 3.279 .853 & 623.740 & 3.903 .593 \\
\hline Equador & 6.050 & 7.899 .151 & 145.807 & 3.842 .977 & 721.713 & 2.725 .759 & 569.408 & 3.295 .167 \\
\hline Espírito Santo & 10.414 & 8.030 .393 & 160.928 & 3.842 .977 & 634.049 & 2.629 .208 & 577.301 & 3.206 .510 \\
\hline Extremoz & 22.473 & 22.270 .645 & 2.887 .735 & 7.685 .954 & 2.189 .077 & 1.448 .821 & 768.875 & 2.217 .696 \\
\hline Felipe Guerra** & & & & 3.842 .977 & & 2.370 .026 & 503.472 & 2.873 .499 \\
\hline Fernando Pedroza & 2.964 & 6.459 .029 & 129.311 & 3.842 .977 & 400.607 & 107.325 & 201.204 & 308.529 \\
\hline Florânia & 8.540 & 7.788 .433 & 244.915 & 3.842 .977 & 676.051 & 7.688 .508 & 2.248 .614 & 9.937 .122 \\
\hline Francisco Dantas & 3.011 & 5.449 .417 & 114.304 & 3.842 .977 & 420.158 & 823.402 & 303.938 & 1.127 .340 \\
\hline Frutuoso Gomes & 4.482 & 6.916 .090 & 385.443 & 3.842 .977 & 482.441 & 2.570 .985 & 671.847 & 3.242 .832 \\
\hline Galinhos** & & & & 3.842 .977 & & 112.418 & 78.043 & 190.461 \\
\hline Goianinha & 20.997 & 34.815 .376 & 1.637 .480 & 7.685 .954 & 4.165 .651 & 11.426 .024 & 9.934 .873 & 21.360 .897 \\
\hline $\begin{array}{l}\text { Governador Dix- } \\
\text { Sept Rosado }\end{array}$ & 12.747 & 18.734 .282 & 2.340 .216 & 5.123 .969 & 2.733 .467 & 8.708 .232 & 2.757 .550 & 11.465 .782 \\
\hline Grossos & 9.741 & 13.425 .517 & 316.817 & 3.842 .977 & 3.059 .428 & 16.101 & 284.302 & 300.402 \\
\hline Guamaré*** & & & & 5.123 .969 & & 2.339 .195 & 1.900 .740 & 4.239 .935 \\
\hline Ielmo Marinho & 12.018 & 20.558 .647 & 486.236 & 5.123 .969 & 669.660 & 2.705 .718 & 363.280 & 3.068 .997 \\
\hline Ipanguaçu & 13.868 & 14.464 .296 & 499.193 & 5.123 .969 & 4.340 .408 & 9.623 .688 & 2.028 .968 & 11.652 .656 \\
\hline Ipueira & 2.097 & 5.496 .375 & 120.430 & 3.842 .977 & 394.065 & 625.870 & 128.144 & 754.014 \\
\hline Itajá & 6.599 & 8.329 .800 & 267.953 & 3.842 .977 & 651.600 & 861.372 & 284.199 & 1.145 .571 \\
\hline Itaú & 5.936 & 7.457 .925 & 254.318 & 3.842 .977 & 526.901 & 1.282 .631 & 258.697 & 1.541 .328 \\
\hline Jaçanã & 8.017 & 9.422 .038 & 202.956 & 3.842 .977 & 612.047 & 3.974 .473 & 515.339 & 4.489 .811 \\
\hline Jandaíra & 6.641 & 9.721 .359 & 228.313 & 3.842 .977 & 543.934 & 1.672 .954 & 325.843 & 1.998 .797 \\
\hline Janduís & 5.569 & 8.466 .847 & 231.612 & 3.842 .977 & 623.958 & 2.184 .815 & 948.070 & 3.132 .884 \\
\hline Januário Cicco & 8.548 & 10.364 .154 & 261.657 & 3.842 .977 & 592.833 & 2.357 .774 & 243.226 & 2.601 .001 \\
\hline Japi & 5.757 & 6.862 .226 & 140.125 & 3.842 .977 & 478.098 & 2.297 .499 & 434.721 & 2.732 .220 \\
\hline $\begin{array}{l}\text { Jardim de } \\
\text { Angicos }\end{array}$ & 2.607 & 6.809 .770 & 292.090 & 3.842 .977 & 407.745 & 459.149 & 74.233 & 533.383 \\
\hline Jardim de & 14.139 & 14.548 .911 & 399.054 & 6.404 .962 & 1.105 .194 & 4.026 .240 & 1.670 .700 & 5.696 .939 \\
\hline
\end{tabular}




\begin{tabular}{|c|c|c|c|c|c|c|c|c|}
\hline Piranhas & & & & & & & & \\
\hline Jardim do Seridó & 12.362 & 11.226 .632 & 417.931 & 5.123 .969 & 1.380 .913 & 7.645 .040 & 6.842 .990 & 14.488 .030 \\
\hline João Câmara* & 30.333 & 21.534 .300 & 652.900 & 8.966 .946 & 1.565 .900 & 27.236 .967 & 10.547 .155 & 37.784 .122 \\
\hline João Dias & 2.805 & 6.994 .926 & 125.833 & 3.842 .977 & 402.756 & 1.503 .973 & 295.724 & 1.799 .698 \\
\hline José da Penha & 6.157 & 8.066 .578 & 156.517 & 3.842 .977 & 513.294 & 5.083 .212 & 965.350 & 6.048 .563 \\
\hline Jucurutu & 18.014 & 20.694 .279 & 891.263 & 7.685 .954 & 1.663 .333 & 13.503 .771 & 3.478 .321 & 16.982 .093 \\
\hline Jundiá & 3.626 & 6.505 .088 & 129.252 & 3.842 .978 & 415.108 & 258.131 & 119.309 & 377.441 \\
\hline Lagoa d'Anta & 6.119 & 8.202 .197 & 156.570 & 3.842 .977 & 508.087 & 2.041 .005 & 456.750 & 2.497 .755 \\
\hline Lagoa de Pedras & 7.205 & 6.775 .975 & 92.307 & 3.842 .977 & 601.886 & 2.858 .359 & 349.749 & 3.208 .108 \\
\hline Lagoa de Velhos* & 2.704 & 5.160 .900 & 53.600 & 3.842 .977 & 365.500 & 725.195 & 115.619 & 840.814 \\
\hline Lagoa Nova & 13.574 & 14.232 .540 & 286.233 & 5.123 .969 & 775.282 & 4.834 .136 & 915.728 & 5.749 .864 \\
\hline Lagoa Salgada* & 7.177 & 7.671 .300 & 195.300 & 3.842 .977 & 474.500 & 3.381 .129 & 370.716 & 3.751 .845 \\
\hline Lajes & 10.737 & 10.287 .754 & 228.841 & 5.123 .969 & 797.981 & 5.616 .080 & 3.643 .657 & 9.259 .737 \\
\hline Lajes Pintadas & 4.333 & 7.982 .284 & 163.810 & 3.842 .977 & 454.240 & 2.637 .708 & 328.807 & 2.966 .516 \\
\hline Lucrecia & 3.522 & 7.095 .324 & 195.008 & 3.842 .977 & 456.469 & 2.399 .882 & 344.095 & 2.743 .977 \\
\hline Luís Gomes & 10.060 & 12.466 .735 & 298.616 & 3.842 .977 & 616.566 & 6.154 .236 & 1.818 .920 & 7.973 .156 \\
\hline Macaíba & 65.361 & 70.988 .354 & 5.067 .854 & 15.371 .908 & 17.936 .073 & 16.706 .858 & 21.699 .399 & 38.406 .257 \\
\hline Macau* & 27.129 & 47.139 .200 & 3.394 .900 & 8.966 .946 & 10.405 .300 & 5.170 .925 & 32.073 .034 & 37.243 .959 \\
\hline Major Sales & 3.571 & 7.293 .521 & 110.954 & 3.842 .977 & 423.605 & 2.501 .780 & 579.715 & 3.081 .495 \\
\hline Marcelino Vieira & 8.342 & 8.979 .631 & 204.857 & 3.842 .977 & 581.205 & 5.956 .121 & 1.055 .161 & 7.011 .282 \\
\hline Martins & 8.331 & 7.786 .709 & 322.880 & 3.842 .977 & 750.205 & 9.280 .842 & 2.901 .895 & 12.182 .737 \\
\hline Maxaranguape & 9.251 & 12.114 .868 & 852.067 & 3.842 .977 & 677.062 & 1.349 .412 & 232.932 & 1.582 .344 \\
\hline Messias Targino & 3.907 & 7.238 .271 & 197.574 & 3.842 .977 & 480.132 & 1.903 .882 & 693.573 & 2.597 .455 \\
\hline Montanhas & 12.762 & 11.403 .087 & 238.601 & 5.123 .969 & 724.075 & 3.023 .410 & 1.085 .612 & 4.109 .022 \\
\hline Monte Alegre & 21.225 & 17.682 .102 & 393.120 & 7.685 .954 & 1.082 .381 & 12.404 .189 & 4.023 .608 & 16.427 .797 \\
\hline $\begin{array}{l}\text { Monte das } \\
\text { Gameleiras* }\end{array}$ & 2.827 & 5.089 .900 & 66.100 & 3.842 .977 & 348.200 & 1.031 .156 & 362.958 & 1.394 .115 \\
\hline Mossoró & 241.645 & 336.661 .497 & 43.366 .109 & 44.700 .998 & 73.045 .911 & 50.672 .425 & 171.641 .751 & 222.314 .176 \\
\hline Natal & 798.065 & 1.093 .138 .697 & 222.706 .144 & 140.052 .611 & 203.572 .569 & 67.657 .739 & 671.579 .939 & 739.237 .678 \\
\hline Nísia Floresta & 23.655 & 25.895 .690 & 3.594 .973 & 7.685 .954 & 1.755 .090 & 3.620 .544 & 1.335 .685 & 4.956 .229 \\
\hline Nova Cruz & 36.336 & 28.948 .053 & 965.732 & 10.247 .939 & 1.941 .609 & 29.118 .436 & 12.304 .701 & 41.423 .138 \\
\hline $\begin{array}{l}\text { Olho-d'Água do } \\
\text { Borges }\end{array}$ & 4.570 & 6.624 .424 & 208.870 & 3.842 .977 & 335.841 & 2.596 .212 & 482.514 & 3.078 .727 \\
\hline Ouro Branco & 5.124 & 6.686 .438 & 148.449 & 3.842 .977 & 475.011 & 2.983 .089 & 727.947 & 3.711 .037 \\
\hline Paraná & 4.004 & 6.478 .510 & 126.612 & 3.842 .977 & 442.897 & 2.876 .951 & 707.437 & 3.584 .388 \\
\hline Paraú** & & & & 3.842 .977 & & 797.649 & 240.346 & 1.037 .995 \\
\hline Parazinho & 4.920 & 7.892 .153 & 183.377 & 3.842 .977 & 486.976 & 1.562 .175 & 226.283 & 1.788 .457 \\
\hline
\end{tabular}




\begin{tabular}{|c|c|c|c|c|c|c|c|c|}
\hline Parelhas & 20.566 & 19.317 .792 & 728.014 & 7.685 .954 & 1.769 .629 & 10.706 .553 & 8.550 .954 & 19.257 .507 \\
\hline Parnamirim & 178.819 & 186.771 .138 & 30.776 .890 & 44.700 .998 & 37.042 .035 & 47.209 .210 & 62.825 .303 & 110.034 .513 \\
\hline Passa e Fica & 10.718 & 11.736 .269 & 197.383 & 5.123 .969 & 670.491 & 4.825 .914 & 1.045 .741 & 5.871 .654 \\
\hline Passagem & 2.704 & 6.024 .120 & 123.014 & 3.842 .977 & 420.232 & 333.106 & 98.114 & 431.220 \\
\hline Patu* & 11.284 & 9.964 .000 & 314.300 & 5.123 .969 & 677.100 & 12.969 .566 & 4.803 .818 & 17.773 .384 \\
\hline Pau dos Ferros & 27.547 & 26.709 .596 & 1.671 .151 & 8.966 .946 & 2.384 .753 & 31.051 .850 & 17.099 .201 & 48.151 .051 \\
\hline Pedra Grande* & 3.918 & 6.067 .600 & 181.900 & 3.842 .977 & 382.900 & 878.445 & 221.593 & 1.100 .038 \\
\hline Pedra Preta* & 2.706 & 5.233 .200 & 116.000 & 3.842 .977 & 357.700 & 1.071 .931 & 234.385 & 1.306 .316 \\
\hline Pedro Avelino & 7.607 & 9.316 .324 & 249.904 & 3.842 .977 & 671.540 & 3.932 .044 & 1.571 .462 & 5.503 .506 \\
\hline Pedro Velho & 14.073 & 14.296 .696 & 277.287 & 6.404 .962 & 1.013 .690 & 2.929 .915 & 1.103 .394 & 4.033 .309 \\
\hline Pendências & 12.893 & 20.010 .640 & 1.110 .798 & 5.123 .969 & 4.489 .674 & 1.691 .577 & 2.486 .215 & 4.177 .792 \\
\hline Pilões & 3.488 & 6.812 .836 & 167.721 & 3.842 .977 & 448.575 & 2.246 .794 & 412.424 & 2.659 .218 \\
\hline Poço Branco* & 12.270 & 10.591 .800 & 256.000 & 5.123 .969 & 593.100 & 1.464 .472 & 448.817 & 1.913 .289 \\
\hline Portalegre & 7.056 & 9.375 .698 & 164.211 & 3.842 .977 & 587.554 & 5.268 .838 & 1.004 .507 & 6.273 .346 \\
\hline Porto do Mangue & 4.947 & 13.564 .472 & 841.008 & 3.842 .977 & 1.885 .454 & 26.363 & 33.446 & 59.808 \\
\hline $\begin{array}{l}\text { Presidente } \\
\text { Juscelino }\end{array}$ & 8.552 & 12.795 .110 & 206.475 & 3.842 .977 & 569.704 & 3.336 .875 & 622.744 & 3.959 .619 \\
\hline Pureza & 8.287 & 9.648 .348 & 132.829 & 3.842 .977 & 599.454 & 438.264 & 86.323 & 524.588 \\
\hline Rafael Fernandes & 4.750 & 6.006 .634 & 71.387 & 3.842 .977 & 483.691 & 2.580 .485 & 623.710 & 3.204 .195 \\
\hline Rafael Godeiro & 3.226 & 6.773 .982 & 43.171 & 3.842 .977 & 423.106 & 2.489 .557 & 396.041 & 2.885 .598 \\
\hline Riacho da Cruz & 3.121 & 6.329 .803 & 127.022 & 3.842 .977 & 418.622 & 1.170 .612 & 321.522 & 1.492 .135 \\
\hline Riacho de Santana & 4.419 & 7.259 .827 & 155.596 & 3.842 .977 & 454.249 & 3.075 .396 & 547.267 & 3.622 .662 \\
\hline Riachuelo & 7.045 & 8.446 .357 & 203.496 & 3.842 .977 & 609.529 & 1.624 .269 & 389.069 & 2.013 .338 \\
\hline Rio do Fogo** & & & & 3.842 .977 & & 1.474 .018 & 254.473 & 1.728 .491 \\
\hline $\begin{array}{l}\text { Rodolfo } \\
\text { Fernandes }\end{array}$ & 4.704 & 8.676 .264 & 297.502 & 4.661 .301 & 718.106 & 2.302 .129 & 435.310 & 2.737 .439 \\
\hline Ruy Barbosa & 3.729 & 6.798 .641 & 119.926 & 3.842 .977 & 434.977 & 1.541 .273 & 329.446 & 1.870 .719 \\
\hline Santa Cruz & 34.769 & 34.828 .275 & 1.291 .488 & 10.247 .939 & 1.660 .610 & 48.953 .251 & 18.897 .525 & 67.850 .775 \\
\hline Santa Maria & 4.813 & 8.030 .634 & 108.553 & 3.842 .977 & 480.806 & 767.400 & 195.441 & 962.841 \\
\hline Santana do Matos & 14.690 & 14.727 .731 & 579.764 & 6.404 .962 & 1.013 .180 & 10.500 .725 & 2.619 .043 & 13.119 .767 \\
\hline Santana do Seridó & 2.816 & 5.816 .041 & 108.622 & 3.842 .977 & 473.152 & 411.620 & 108.531 & 520.151 \\
\hline Santo Antônio & 21.905 & 19.667 .916 & 524.387 & 7.685 .954 & 1.388 .234 & 20.623 .082 & 8.418 .207 & 29.041 .288 \\
\hline $\begin{array}{l}\text { São Bento do } \\
\text { Norte** }\end{array}$ & & & & 3.842 .977 & & 1.982 .401 & 497.506 & 2.479 .907 \\
\hline $\begin{array}{l}\text { São Bento do } \\
\text { Trairí }\end{array}$ & 3.820 & 7.428 .704 & 143.764 & 3.842 .977 & 415.835 & 1.529 .574 & 180.583 & 1.710 .157 \\
\hline São Fernando & 3.483 & 7.854 .732 & 147.651 & 3.842 .977 & 444.002 & 1.871 .685 & 413.851 & 2.285 .537 \\
\hline
\end{tabular}




\begin{tabular}{|c|c|c|c|c|c|c|c|c|}
\hline $\begin{array}{l}\text { São Francisco do } \\
\text { Oeste }\end{array}$ & 3.780 & 6.308 .153 & 82.446 & 3.842 .977 & 471.157 & 2.116 .925 & 608.615 & 2.725 .540 \\
\hline $\begin{array}{l}\text { São Gonçalo do } \\
\text { Amarante }\end{array}$ & 79.776 & 84.052 .980 & 4.571 .955 & 16.652 .900 & 18.440 .081 & 32.482 .491 & 17.336 .815 & 49.819 .307 \\
\hline $\begin{array}{l}\text { São João do } \\
\text { Sabugi }\end{array}$ & 5.934 & 6.831 .364 & 83.440 & 3.842 .977 & 545.498 & 3.483 .519 & 747.519 & 4.231 .037 \\
\hline $\begin{array}{l}\text { São José de } \\
\text { Mipibu }\end{array}$ & 38.109 & 38.035 .576 & 1.221 .907 & 10.247 .939 & 3.279 .870 & 13.186 .726 & 11.087 .999 & 24.274 .724 \\
\hline $\begin{array}{l}\text { São José do } \\
\text { Campestre** }\end{array}$ & & & & 5.123 .969 & & 8.834 .122 & 2.279 .729 & 11.113 .851 \\
\hline $\begin{array}{l}\text { São José do } \\
\text { Seridó }\end{array}$ & 4.042 & 6.669 .816 & 78.273 & 3.842 .977 & 608.279 & 2.344 .724 & 561.970 & 2.906 .694 \\
\hline São Miguel & 23.288 & 23.755 .664 & 673.362 & 7.685 .954 & 1.137 .091 & 23.503 .142 & 7.506 .800 & 31.009 .942 \\
\hline $\begin{array}{l}\text { São Miguel do } \\
\text { Gostoso }\end{array}$ & 9.093 & 12.029 .827 & 658.468 & 3.842 .977 & 582.293 & 796.677 & 94.507 & 891.184 \\
\hline $\begin{array}{l}\text { São Paulo do } \\
\text { Potengi }\end{array}$ & 14.918 & 17.903 .228 & 430.788 & 6.404 .962 & 1.414 .669 & 11.616 .785 & 4.802 .620 & 16.419 .405 \\
\hline São Pedro & 6.612 & 8.713 .299 & 175.410 & 3.842 .977 & 521.806 & 2.403 .599 & 282.878 & 2.686 .476 \\
\hline São Rafael & 8.350 & 8.001 .693 & 204.173 & 3.842 .977 & 597.752 & 4.292 .493 & 810.349 & 5.102 .841 \\
\hline São Tomé & 11.445 & 11.369 .504 & 197.828 & 5.123 .969 & 681.061 & 5.982 .544 & 1.332 .020 & 7.314 .564 \\
\hline São Vicente & 5.992 & 7.776 .307 & 142.506 & 3.842 .977 & 520.164 & 2.990 .511 & 565.859 & 3.556 .370 \\
\hline $\begin{array}{l}\text { Senador Eloi de } \\
\text { Souza** }\end{array}$ & & & & 3.842 .977 & & 1.812 .927 & 232.668 & 2.045 .595 \\
\hline $\begin{array}{l}\text { Senador Georgino } \\
\text { Avelino }\end{array}$ & 3.806 & 7.455 .154 & 297.318 & 3.842 .977 & 683.458 & 694.144 & 218.804 & 912.948 \\
\hline $\begin{array}{l}\text { Serra de São } \\
\text { Bento }\end{array}$ & 5.968 & 7.151 .621 & 80.354 & 3.842 .977 & 477.003 & 3.024 .361 & 406.235 & 3.430 .597 \\
\hline Serra do Mel & 9.505 & 14.624 .696 & 907.101 & 3.842 .977 & 1.330 .451 & 173.613 & 62.348 & 235.961 \\
\hline $\begin{array}{l}\text { Serra Negra do } \\
\text { Norte }\end{array}$ & 7.445 & 9.482 .305 & 241.076 & 3.842 .977 & 629.111 & 5.170 .104 & 941.238 & 6.111 .342 \\
\hline Serrinha* & 6.750 & 7.124 .100 & 166.400 & 3.842 .977 & 519.800 & 3.125 .846 & 379.152 & 3.504 .998 \\
\hline $\begin{array}{l}\text { Serrinha dos } \\
\text { Pintos }\end{array}$ & 4.488 & 7.093 .679 & 92.861 & 3.842 .977 & 454.328 & 1.765 .955 & 272.779 & 2.038 .734 \\
\hline Severiano Melo & 5.728 & 8.758 .432 & 274.787 & 3.842 .977 & 776.972 & 2.792 .388 & 477.411 & 3.269 .800 \\
\hline Sítio Novo & 5.380 & 8.704 .069 & 166.051 & 3.842 .977 & 446.310 & 1.561 .713 & 243.667 & 1.805 .380 \\
\hline Taboleiro Grande & 2.349 & 5.950 .798 & 63.539 & 3.842 .977 & 381.493 & 563.602 & 169.614 & 733.217 \\
\hline Taipu & 12.115 & 11.612 .012 & 275.614 & 5.123 .969 & 923.546 & 1.714 .770 & 506.144 & 2.220 .914 \\
\hline Tangará & 13.482 & 13.947 .138 & 682.583 & 5.123 .969 & 983.916 & 5.017 .149 & 895.822 & 5.912 .971 \\
\hline
\end{tabular}




\begin{tabular}{|c|c|c|c|c|c|c|c|c|}
\hline Tenente Ananias & 9.591 & 9.718 .594 & 149.619 & 3.842 .977 & 646.812 & 6.043 .481 & 1.393 .468 & 7.436 .949 \\
\hline $\begin{array}{l}\text { Tenente } \\
\text { Laurentino Cruz }\end{array}$ & 5.284 & 7.806 .595 & 83.713 & 3.842 .977 & 478.460 & 2.195 .977 & 311.705 & 2.507 .682 \\
\hline Tibau** & & & & 3.842 .977 & & 8.861 & 85.706 & 94.566 \\
\hline Tibau do Sul & 11.347 & 17.472 .682 & 5.282 .991 & 5.123 .969 & 1.262 .375 & 1.702 .177 & 439.446 & 2.141 .623 \\
\hline $\begin{array}{l}\text { Timbaúba dos } \\
\text { Batistas }\end{array}$ & 2.364 & 6.879 .774 & 69.254 & 3.842 .977 & 415.127 & 1.484 .266 & 254.446 & 1.738 .712 \\
\hline Touros & 30.325 & 28.777 .998 & 1.534 .295 & 8.966 .946 & 1.826 .477 & 16.562 .930 & 3.462 .787 & 20.025 .717 \\
\hline Triunfo Potiguar & 3.359 & 7.375 .818 & 180.755 & 3.842 .977 & 450.759 & 630.313 & 99.869 & 730.181 \\
\hline Umarizal & 10.939 & 11.743 .692 & 582.353 & 5.123 .969 & 818.957 & 12.012 .078 & 3.374 .504 & 15.386 .581 \\
\hline Upanema & 13.126 & 17.130 .445 & 1.621 .360 & 5.123 .969 & 1.422 .768 & 2.955 .657 & 781.029 & 3.736 .686 \\
\hline Várzea & 5.435 & 6.810 .223 & 121.757 & 3.842 .977 & 499.023 & 2.797 .981 & 320.793 & 3.118 .773 \\
\hline Venha-Ver & 3.597 & 7.496 .560 & 127.309 & 3.842 .977 & 427.516 & 1.563 .159 & 349.334 & 1.912 .493 \\
\hline Vera Cruz & 10.652 & 11.270 .967 & 170.990 & 5.123 .969 & 643.415 & 4.141 .278 & 690.818 & 4.832 .096 \\
\hline Viçosa & 1.826 & 5.984 .003 & 128.224 & 3.842 .977 & 393.029 & 679.035 & 133.771 & 812.806 \\
\hline Vila Flor* & 2.647 & 5.115 .500 & 175.900 & 3.842 .977 & 674.000 & 95.211 & 124.469 & 219.680 \\
\hline
\end{tabular}

FONTE: Os dados de Receita Total, Receitas Tributárias Próprias, FPM e Cota-ICMS foram retirados do Sistema FIBRA 2008, da Secretaria do Tesouro Nacional do Ministério da Fazenda (STN/MF). Os valores referentes a soma dos benefícios previdenciários urbanos e rurais emitidos no ano de 2008 no RN foram retirados de SINTESE/DATAPREV

Notas:

(1) A partir de 1998, dos valores do FPM já está descontada a parcela de $15 \%$ (quinze por cento) destinada ao FUNDEF.

(2) A partir 2007, dos valores do FPM, já está descontada a parcela destinada ao FUNDEB.

(3) Foram excluídos os centavos.

(4) O Valor dos benefícios emitidos corresponde ao valor líquido (diferença entre valor bruto e descontos) dos créditos emitidos pelo Instituto Nacional de Previdência Social - INSS para pagamento de benefícios do Regime Geral de Previdência Social, Encargos Previdenciários da União e Amparos Assistenciais previstos na Lei Orgânica da Assistência Social, classificados pelo município do órgão pagador.

* Para estes municípios os dados de receita total, receita própria e ICMS foram extraídos do Anuário Multi Cidades 2008, em razão de tais informações não constarem no Sistema FIBRA 2008, da Secretaria do Tesouro Nacional/MF.

* Para estes municípios não foram lançados dados receita total, receita própria e ICMS por não estarem disponíveis nas fontes estudadas, a saber, no Sistema FIBRA 2008, da Secretaria do

Tesouro Nacional/MF

no

Anuário

Multi

Cidades

2008. 


\begin{abstract}
APÊNDICE II
RelaÇão da RENDA PREVIDENCIÁRIA COM O FPM E O IDH-M, POR MUNICÍPIO do Rio GRANDE do NORTE
\end{abstract}




\begin{tabular}{|c|c|c|c|c|c|}
\hline MUNICIPIO & População & $\begin{array}{c}\text { (A) Valor Total } \\
\text { dos benefícios } \\
\text { emitidos em } \\
2008 \text { no RN } \\
\text { (RURAL + } \\
\text { URBANO) em } \\
\text { R\$ } \\
\end{array}$ & $\begin{array}{c}\text { (B) Cota } \\
\text { FPM/2008 em } \\
\text { R\$ }\end{array}$ & $(\mathbf{A}) /(\mathbf{B})$ & $\begin{array}{c}\text { Posição } \\
\text { estadual/índice } \\
\text { do IDH/PNUD } \\
2000\end{array}$ \\
\hline Acari & 11.222 & 10.190 .511 & 5.123 .969 & 1,98 & 16 \\
\hline Açu & 52.824 & 72.339 .586 & 14.090 .916 & 5,13 & 27 \\
\hline Afonso Bezerra & 10.628 & 7.923 .380 & 5.123 .969 & 1,54 & 91 \\
\hline Água Nova & 2.929 & 1.885 .019 & 3.842 .977 & 0,49 & 152 \\
\hline Alexandria & 14.127 & 20.609 .919 & 6.404 .962 & 3,21 & 71 \\
\hline Almino Afonso & 5.087 & 3.536 .557 & 3.842 .977 & 0,92 & 63 \\
\hline $\begin{array}{c}\text { Alto do } \\
\text { Rodrigues }\end{array}$ & 11.817 & 4.375 .447 & 5.123 .969 & 0,85 & 22 \\
\hline Angicos & 11.544 & 10.485 .245 & 5.123 .969 & 2,04 & 23 \\
\hline Antônio Martins & 7.205 & 6.162 .022 & 3.842 .977 & 1,60 & 75 \\
\hline Apodi & 35.648 & 34.739 .460 & 10.247 .939 & 3,38 & 44 \\
\hline Areia Branca & 25.147 & 40.954 .837 & 8.966 .946 & 4,56 & 13 \\
\hline Ares & 12.611 & 3.943 .959 & 5.123 .969 & 0,76 & 100 \\
\hline Augusto Severo & 9.194 & 14.371 .222 & 3.842 .977 & 3,73 & 121 \\
\hline Baía Formosa & 8.726 & 2.138 .301 & 3.842 .977 & 0,55 & 57 \\
\hline Baraúna & 23.860 & 12.652 .087 & 7.685 .954 & 1,64 & 131 \\
\hline Barcelona & 4.040 & 2.362 .262 & 3.842 .977 & 0,61 & 117 \\
\hline $\begin{array}{c}\text { Bento } \\
\text { Fernandes }\end{array}$ & 5505 & 1.962 .567 & 3.842 .977 & 0,51 & 158 \\
\hline Bodó & 2.611 & 372.667 & 3.842 .977 & 0,09 & 141 \\
\hline Bom Jesus & 8.721 & 4.669 .004 & 3.842 .977 & 1,21 & 96 \\
\hline Brejinho & 11.476 & 3.639 .933 & 5.123 .969 & 0,71 & 97 \\
\hline $\begin{array}{l}\text { Caiçara do } \\
\text { Norte }\end{array}$ & 6.393 & 452.068 & 3.842 .977 & 0,11 & 81 \\
\hline $\begin{array}{c}\text { Caiçara do Rio } \\
\text { do Vento }\end{array}$ & 3.158 & 1.480 .958 & 3.842 .977 & 0,38 & 108 \\
\hline Caicó & 62.497 & 69.438 .503 & 14.090 .916 & 4,92 & 3 \\
\hline $\begin{array}{c}\text { Campo } \\
\text { Redondo }\end{array}$ & 10.793 & 6.712 .589 & 5.123 .969 & 1,31 & 79 \\
\hline Canguaretama & 30.237 & 19.905 .885 & 8.966 .946 & 2,21 & 133 \\
\hline Caraúbas & 20.333 & 22.709 .881 & 7.685 .954 & 2,95 & 113 \\
\hline $\begin{array}{c}\text { Carnaúba dos } \\
\text { Dantas }\end{array}$ & 7.041 & 3.616 .459 & 3.842 .977 & 0,94 & 49 \\
\hline Carnaubais & 9.578 & 1.628 .269 & 3.842 .977 & 0,42 & 4 \\
\hline Ceará-Mirim & 67.416 & 50.493 .906 & 15.371 .908 & 3,28 & 52 \\
\hline Cerro Corá & 11.207 & 6.706 .161 & 5.123 .969 & 1,30 & 147 \\
\hline $\begin{array}{l}\text { Coronel } \\
\text { Ezequiel } \\
\end{array}$ & 5.280 & 3.275 .941 & 3.842 .977 & 0,85 & 130 \\
\hline $\begin{array}{c}\text { Coronel João } \\
\text { Pessoa }\end{array}$ & 4.970 & 2.859 .645 & 3.842 .977 & 0,74 & 146 \\
\hline Cruzeta & 8.046 & 4.183 .560 & 3.842 .977 & 1,08 & 12 \\
\hline Currais Novos & 43.315 & 59.983 .688 & 11.528 .931 & 5,20 & 9 \\
\hline $\begin{array}{c}\text { Doutor } \\
\text { Severiano }\end{array}$ & 6.615 & 4.352 .510 & 3.842 .977 & 1,13 & 134 \\
\hline Encanto & 5.316 & 3.903 .593 & 3.842 .977 & 1,01 & 98 \\
\hline Equador & 6.050 & 3.295 .167 & 3.842 .977 & 0,85 & 33 \\
\hline Espírito Santo & 10.414 & 3.206 .510 & 3.842 .977 & 0,83 & 156 \\
\hline Extremoz & 22.473 & 2.217 .696 & 7.685 .954 & 0,28 & 18 \\
\hline Felipe Guerra & & 2.873 .499 & 3.842 .977 & 0,74 & 78 \\
\hline Fernando & 2.964 & 308.529 & 3.842 .977 & 0,08 & 99 \\
\hline
\end{tabular}




\begin{tabular}{|c|c|c|c|c|c|}
\hline Pedroza & & & & & \\
\hline Florânia & 8.540 & 9.937 .122 & 3.842 .977 & 2,58 & 38 \\
\hline $\begin{array}{c}\text { Francisco } \\
\text { Dantas }\end{array}$ & 3.011 & 1.127 .340 & 3.842 .977 & 0,29 & 103 \\
\hline Frutuoso Gomes & 4.482 & 3.242 .832 & 3.842 .977 & 0,84 & 66 \\
\hline Galinhos & & 190.461 & 3.842 .977 & 0,04 & 118 \\
\hline Goianinha & 20.997 & 21.360 .897 & 7.685 .954 & 2,77 & 50 \\
\hline $\begin{array}{l}\text { Governador } \\
\text { Dix-Sept } \\
\text { Rosado }\end{array}$ & 12.747 & 11.465 .782 & 5.123 .969 & 2,23 & 70 \\
\hline Grossos & 9.741 & 300.402 & 3.842 .977 & 0,07 & 25 \\
\hline Guamaré & & 4.239 .935 & 5.123 .969 & 0,82 & 54 \\
\hline Ielmo Marinho & 12.018 & 3.068 .997 & 5.123 .969 & 0,59 & 149 \\
\hline Ipanguaçu & 13.868 & 11.652 .656 & 5.123 .969 & 2,27 & 116 \\
\hline Ipueira & 2.097 & 754.014 & 3.842 .977 & 0,19 & 20 \\
\hline Itajá & 6.599 & 1.145 .571 & 3.842 .977 & 0,29 & 76 \\
\hline Itaú & 5.936 & 1.541 .328 & 3.842 .977 & 0,40 & 29 \\
\hline Jaçanã & 8.017 & 4.489 .811 & 3.842 .977 & 1,16 & 84 \\
\hline Jandaíra & 6.641 & 1.998 .797 & 3.842 .977 & 0,52 & 162 \\
\hline Janduís & 5.569 & 3.132 .884 & 3.842 .977 & 0,81 & 128 \\
\hline Januário Cicco & 8.548 & 2.601 .001 & 3.842 .977 & 0,67 & 140 \\
\hline Japi & 5.757 & 2.732 .220 & 3.842 .977 & 0,71 & 163 \\
\hline $\begin{array}{l}\text { Jardim de } \\
\text { Angicos }\end{array}$ & 2.607 & 533.383 & 3.842 .977 & 0,13 & 93 \\
\hline $\begin{array}{l}\text { Jardim de } \\
\text { Piranhas }\end{array}$ & 14.139 & 5.696 .939 & 6.404 .962 & 0,88 & 30 \\
\hline $\begin{array}{l}\text { Jardim do } \\
\text { Seridó }\end{array}$ & 12.362 & 14.488 .030 & 5.123 .969 & 2,82 & 10 \\
\hline João Câmara & 30.333 & 37.784 .122 & 8.966 .946 & 4,21 & 68 \\
\hline João Dias & 2.805 & 1.799 .698 & 3.842 .977 & 0,46 & 148 \\
\hline José da Penha & 6.157 & 6.048 .563 & 3.842 .977 & 1,57 & 90 \\
\hline Jucurutu & 18.014 & 16.982 .093 & 7.685 .954 & 2,20 & 74 \\
\hline Jundiá & 3.626 & 377.441 & 3.842 .978 & 0,09 & \\
\hline Lagoa d'Anta & 6.119 & 2.497 .755 & 3.842 .977 & 0,65 & 129 \\
\hline Lagoa de Pedras & 7.205 & 3.208 .108 & 3.842 .977 & 0,83 & 143 \\
\hline $\begin{array}{l}\text { Lagoa de } \\
\text { Velhos }\end{array}$ & 2.704 & 840.814 & 3.842 .977 & 0,21 & 88 \\
\hline Lagoa Nova & 13.574 & 5.749 .864 & 5.123 .969 & 1,12 & 106 \\
\hline Lagoa Salgada & 7.177 & 3.751 .845 & 3.842 .977 & 0,97 & 136 \\
\hline Lajes & 10.737 & 9.259 .737 & 5.123 .969 & 1,80 & 64 \\
\hline Lajes Pintadas & 4.333 & 2.966 .516 & 3.842 .977 & 0,77 & 40 \\
\hline Lucrecia & 3.522 & 2.743 .977 & 3.842 .977 & 0,71 & 37 \\
\hline Luís Gomes & 10.060 & 7.973 .156 & 3.842 .977 & 2,07 & 56 \\
\hline Macaíba & 65.361 & 38.406 .257 & 15.371 .908 & 2,49 & 34 \\
\hline Macau & 27.129 & 37.243 .959 & 8.966 .946 & 4,15 & 21 \\
\hline Major Sales & 3.571 & 3.081 .495 & 3.842 .977 & 0,80 & 89 \\
\hline $\begin{array}{l}\text { Marcelino } \\
\text { Vieira }\end{array}$ & 8.342 & 7.011 .282 & 3.842 .977 & 1,82 & 115 \\
\hline Martins & 8.331 & 12.182 .737 & 3.842 .977 & 3,17 & 19 \\
\hline Maxaranguape & 9.251 & 1.582 .344 & 3.842 .977 & 0,41 & 123 \\
\hline Messias Targino & 3.907 & 2.597 .455 & 3.842 .977 & 0,67 & 112 \\
\hline Montanhas & 12.762 & 4.109 .022 & 5.123 .969 & 0,80 & 154 \\
\hline Monte Alegre & 21.225 & 16.427 .797 & 7.685 .954 & 2,13 & 55 \\
\hline $\begin{array}{l}\text { Monte das } \\
\text { Gameleiras }\end{array}$ & 2.827 & 1.394 .115 & 3.842 .977 & 0,36 & 145 \\
\hline Mossoró & 241.645 & 222.314 .176 & 44.700 .998 & 4,97 & 6 \\
\hline Natal & 798.065 & 739.237 .678 & 140.052 .611 & 5,27 & 1 \\
\hline Nísia Floresta & 23.655 & 4.956 .229 & 7.685 .954 & 0,64 & 32 \\
\hline
\end{tabular}




\begin{tabular}{|c|c|c|c|c|c|}
\hline Nova Cruz & 36.336 & 41.423 .138 & 10.247 .939 & 4,04 & 109 \\
\hline $\begin{array}{c}\text { Olho-d'Água do } \\
\text { Borges }\end{array}$ & 4.570 & 3.078 .727 & 3.842 .977 & 0,80 & 87 \\
\hline Ouro Branco & 5.124 & 3.711 .037 & 3.842 .977 & 0,96 & 15 \\
\hline Paraná & 4.004 & 3.584 .388 & 3.842 .977 & 0,93 & 122 \\
\hline Paraú & & 1.037 .995 & 3.842 .977 & 0,27 & 119 \\
\hline Parazinho & 4.920 & 1.788 .457 & 3.842 .977 & 0,46 & 164 \\
\hline Parelhas & 20.566 & 19.257 .507 & 7.685 .954 & 2,50 & 14 \\
\hline Parnamirim & 178.819 & 110.034 .513 & 44.700 .998 & 2,46 & 2 \\
\hline Passa e Fica & 10.718 & 5.871 .654 & 5.123 .969 & 1,14 & 120 \\
\hline Passagem & 2.704 & 431.220 & 3.842 .977 & 0,11 & 51 \\
\hline Patu & 11.284 & 17.773 .384 & 5.123 .969 & 3,46 & 28 \\
\hline Pau dos Ferros & 27.547 & 48.151 .051 & 8.966 .946 & 5,37 & 7 \\
\hline Pedra Grande & 3.918 & 1.100 .038 & 3.842 .977 & 0,28 & 153 \\
\hline Pedra Preta & 2.706 & 1.306 .316 & 3.842 .977 & 0,34 & 161 \\
\hline Pedro Avelino & 7.607 & 5.503 .506 & 3.842 .977 & 1,43 & 102 \\
\hline Pedro Velho & 14.073 & 4.033 .309 & 6.404 .962 & 0,63 & 95 \\
\hline Pendências & 12.893 & 4.177 .792 & 5.123 .969 & 0,81 & 82 \\
\hline Pilões & 3.488 & 2.659 .218 & 3.842 .977 & 0,69 & 59 \\
\hline Poço Branco & 12.270 & 1.913 .289 & 5.123 .969 & 0,37 & 125 \\
\hline Portalegre & 7.056 & 6.273 .346 & 3.842 .977 & 1,63 & 77 \\
\hline $\begin{array}{l}\text { Porto do } \\
\text { Mangue }\end{array}$ & 4.947 & 59.808 & 3.842 .977 & 0,01 & 135 \\
\hline $\begin{array}{c}\text { Presidente } \\
\text { Juscelino }\end{array}$ & 8.552 & 3.959 .619 & 3.842 .977 & 1,03 & \\
\hline Pureza & 8.287 & 524.588 & 3.842 .977 & 0,13 & 160 \\
\hline $\begin{array}{c}\text { Rafael } \\
\text { Fernandes }\end{array}$ & 4.750 & 3.204 .195 & 3.842 .977 & 0,83 & 47 \\
\hline Rafael Godeiro & 3.226 & 2.885 .598 & 3.842 .977 & 0,75 & 72 \\
\hline Riacho da Cruz & 3.121 & 1.492 .135 & 3.842 .977 & 0,38 & 101 \\
\hline $\begin{array}{l}\text { Riacho de } \\
\text { Santana }\end{array}$ & 4.419 & 3.622 .662 & 3.842 .977 & 0,94 & 104 \\
\hline Riachuelo & 7.045 & 2.013 .338 & 3.842 .977 & 0,52 & 39 \\
\hline Rio do Fogo & & 1.728 .491 & 3.842 .977 & 0,45 & 137 \\
\hline $\begin{array}{l}\text { Rodolfo } \\
\text { Fernandes }\end{array}$ & 4.704 & 2.737 .439 & 4.661 .301 & 0,58 & 45 \\
\hline Ruy Barbosa & 3.729 & 1.870 .719 & 3.842 .977 & 0,48 & 157 \\
\hline Santa Cruz & 34.769 & 67.850 .775 & 10.247 .939 & 6,62 & 41 \\
\hline Santa Maria & 4.813 & 962.841 & 3.842 .977 & 0,25 & 94 \\
\hline $\begin{array}{c}\text { Santana do } \\
\text { Matos }\end{array}$ & 14.690 & 13.119 .767 & 6.404 .962 & 2,04 & 144 \\
\hline $\begin{array}{l}\text { Santana do } \\
\text { Seridó }\end{array}$ & 2.816 & 520.151 & 3.842 .977 & 0,13 & 24 \\
\hline Santo Antônio & 21.905 & 29.041 .288 & 7.685 .954 & 3,77 & 42 \\
\hline $\begin{array}{c}\text { São Bento do } \\
\text { Norte** }\end{array}$ & & 2.479 .907 & 3.842 .977 & 0,64 & 58 \\
\hline $\begin{array}{c}\text { São Bento do } \\
\text { Trairí }\end{array}$ & 3.820 & 1.710 .157 & 3.842 .977 & 0,44 & 110 \\
\hline São Fernando & 3.483 & 2.285 .537 & 3.842 .977 & 0,59 & 35 \\
\hline $\begin{array}{l}\text { São Francisco } \\
\text { do Oeste }\end{array}$ & 3.780 & 2.725 .540 & 3.842 .977 & 0,70 & 48 \\
\hline $\begin{array}{l}\text { São Gonçalo do } \\
\text { Amarante }\end{array}$ & 79.776 & 49.819 .307 & 16.652 .900 & 2,99 & 17 \\
\hline $\begin{array}{l}\text { São João do } \\
\text { Sabugi }\end{array}$ & 5.934 & 4.231 .037 & 3.842 .977 & 1,10 & 8 \\
\hline $\begin{array}{l}\text { São José de } \\
\text { Mipibu }\end{array}$ & 38.109 & 24.274 .724 & 10.247 .939 & 2,36 & 31 \\
\hline São José do & & 11.113 .851 & 5.123 .969 & 2,16 & 83 \\
\hline
\end{tabular}




\begin{tabular}{|c|c|c|c|c|c|}
\hline Campestre & & & & & \\
\hline $\begin{array}{l}\text { São José do } \\
\text { Seridó }\end{array}$ & 4.042 & 2.906 .694 & 3.842 .977 & 0,75 & 5 \\
\hline São Miguel & 23.288 & 31.009 .942 & 7.685 .954 & 4,03 & 111 \\
\hline $\begin{array}{l}\text { São Miguel do } \\
\text { Gostoso }\end{array}$ & 9.093 & 891.184 & 3.842 .977 & 0,23 & 165 \\
\hline $\begin{array}{l}\text { São Paulo do } \\
\text { Potengi }\end{array}$ & 14.918 & 16.419 .405 & 6.404 .962 & 2,56 & 61 \\
\hline São Pedro & 6.612 & 2.686 .476 & 3.842 .977 & 0,69 & 86 \\
\hline São Rafael & 8.350 & 5.102 .841 & 3.842 .977 & 1,32 & 69 \\
\hline São Tomé & 11.445 & 7.314 .564 & 5.123 .969 & 1,42 & 114 \\
\hline São Vicente & 5.992 & 3.556 .370 & 3.842 .977 & 0,92 & 65 \\
\hline $\begin{array}{c}\text { Senador Eloi de } \\
\text { Souza }\end{array}$ & & 2.045 .595 & 3.842 .977 & 0,53 & 151 \\
\hline $\begin{array}{c}\text { Senador } \\
\text { Georgino } \\
\text { Avelino }\end{array}$ & 3.806 & 912.948 & 3.842 .977 & 0,23 & 53 \\
\hline $\begin{array}{c}\text { Serra de São } \\
\text { Bento }\end{array}$ & 5.968 & 3.430 .597 & 3.842 .977 & 0,89 & 132 \\
\hline Serra do Mel & 9.505 & 235.961 & 3.842 .977 & 0,06 & 107 \\
\hline $\begin{array}{l}\text { Serra Negra do } \\
\text { Norte }\end{array}$ & 7.445 & 6.111 .342 & 3.842 .977 & 1,59 & 36 \\
\hline Serrinha & 6.750 & 3.504 .998 & 3.842 .977 & 0,91 & 138 \\
\hline $\begin{array}{l}\text { Serrinha dos } \\
\text { Pintos }\end{array}$ & 4.488 & 2.038 .734 & 3.842 .977 & 0,53 & 73 \\
\hline Severiano Melo & 5.728 & 3.269 .800 & 3.842 .977 & 0,85 & 80 \\
\hline Sítio Novo & 5.380 & 1.805 .380 & 3.842 .977 & 0,47 & 126 \\
\hline $\begin{array}{l}\text { Taboleiro } \\
\text { Grande }\end{array}$ & 2.349 & 733.217 & 3.842 .977 & 0,19 & 62 \\
\hline Taipu & 12.115 & 2.220 .914 & 5.123 .969 & 0,43 & 155 \\
\hline Tangará & 13.482 & 5.912 .971 & 5.123 .969 & 1,15 & 85 \\
\hline $\begin{array}{l}\text { Tenente } \\
\text { Ananias }\end{array}$ & 9.591 & 7.436 .949 & 3.842 .977 & 1,93 & 139 \\
\hline $\begin{array}{c}\text { Tenente } \\
\text { Laurentino Cruz }\end{array}$ & 5.284 & 2.507 .682 & 3.842 .977 & 0,65 & 92 \\
\hline Tibau & & 94.566 & 3.842 .977 & 0,02 & 26 \\
\hline Tibau do Sul & 11.347 & 2.141 .623 & 5.123 .969 & 0,41 & 43 \\
\hline $\begin{array}{c}\text { Timbaúba dos } \\
\text { Batistas }\end{array}$ & 2.364 & 1.738 .712 & 3.842 .977 & 0,45 & 11 \\
\hline Touros & 30.325 & 20.025 .717 & 8.966 .946 & 2,23 & 142 \\
\hline $\begin{array}{l}\text { Triunfo } \\
\text { Potiguar }\end{array}$ & 3.359 & 730.181 & 3.842 .977 & 0,19 & 159 \\
\hline Umarizal & 10.939 & 15.386 .581 & 5.123 .969 & 3,00 & 60 \\
\hline Upanema & 13.126 & 3.736 .686 & 5.123 .969 & 0,72 & 150 \\
\hline Várzea & 5.435 & 3.118 .773 & 3.842 .977 & 0,81 & 105 \\
\hline Venha-Ver & 3.597 & 1.912 .493 & 3.842 .977 & 0,49 & 166 \\
\hline Vera Cruz & 10.652 & 4.832 .096 & 5.123 .969 & 0,94 & 124 \\
\hline Viçosa & 1.826 & 812.806 & 3.842 .977 & 0,21 & 46 \\
\hline Vila Flor & 2.647 & 219.680 & 3.842 .977 & 0,05 & 67 \\
\hline
\end{tabular}

FONTE: FPM/RN - Sistema FIBRA 2008, STN/MF. Benefícios previdenciários - SINTESE/DATAPREV. IDH$\mathrm{M}$ - PNUD/ONU.

Notas:

(1) Dos valores do FPM, já está descontada a parcela destinada ao FUNDEB.

(2) Foram excluídos os centavos.

(3) O Valor dos benefícios emitidos corresponde ao valor líquido (diferença entre valor bruto e descontos) dos créditos emitidos pelo Instituto Nacional de Previdência Social - INSS para pagamento de benefícios do Regime Geral de Previdência Social, Encargos Previdenciários da União e Amparos Assistenciais previstos na Lei Orgânica da Assistência Social, classificados pelo município do órgão pagador. 


\section{APÊNDICE III}

RElaÇão do PIB MUNiCIPAl COM O VALOR dOS BENEFícios EMITIDOS, POR MuNiCíPIO DO Rio GRANDE DO NORTE 


\begin{tabular}{|c|c|c|c|}
\hline MUNICIPIO & PIB/2007 (A) em R\$ & $\begin{array}{c}\text { Valor Líquido dos Benefícios } \\
\text { Emitidos no RN (RURAL + } \\
\text { URBANO), em R\$ } \\
2007 \text { (B) }\end{array}$ & (A)/(B) em \% \\
\hline Acari & 47.307 .000 & 9.244 .245 & $19,5 \%$ \\
\hline Açu & 276.926 .000 & 67.335 .336 & $24,3 \%$ \\
\hline Afonso Bezerra & 34.649 .000 & 7.285 .077 & $21,0 \%$ \\
\hline Água Nova & 10.612 .000 & 1.753 .967 & $16,5 \%$ \\
\hline Alexandria & 50.403 .000 & 19.047 .849 & $37,7 \%$ \\
\hline Almino Afonso & 18.441 .000 & 3.063 .143 & $16,6 \%$ \\
\hline Alto do Rodrigues & 169.217 .000 & 3.881 .883 & $2,2 \%$ \\
\hline Angicos & 45.120 .000 & 9.686 .196 & $21,4 \%$ \\
\hline Antônio Martins & 23.713 .000 & 5.584 .836 & $23,5 \%$ \\
\hline Apodi & 204.705 .000 & 31.925 .159 & $15,6 \%$ \\
\hline Areia Branca & 420.949 .000 & 39.318 .366 & $9,3 \%$ \\
\hline Ares & 104.203 .000 & 3.335 .717 & $3,2 \%$ \\
\hline Augusto Severo & 33.697 .000 & 13.236 .781 & $39,2 \%$ \\
\hline Baía Formosa & 88.346 .000 & 1.911 .060 & $2,1 \%$ \\
\hline Baraúna & 136.461 .000 & 11.041 .586 & $8,0 \%$ \\
\hline Barcelona & 14.726 .000 & 2.026 .675 & $13,7 \%$ \\
\hline Bento Fernandes & 23.613 .000 & 1.914 .308 & $8,1 \%$ \\
\hline Bodó & 12.789 .000 & 271.319 & $2,1 \%$ \\
\hline Bom Jesus & 33.945 .000 & 4.174 .001 & $12,3 \%$ \\
\hline Brejinho & 45.213 .000 & 2.863 .892 & $6,3 \%$ \\
\hline Caiçara do Norte & 29.712 .000 & 374.709 & $1,2 \%$ \\
\hline Caiçara do Rio do Vento & 12.433 .000 & 1.335 .959 & $10,7 \%$ \\
\hline Caicó & 377.131 .000 & 63.932 .235 & $16,9 \%$ \\
\hline Campo Redondo & 34.662 .000 & 5.965 .239 & $17,2 \%$ \\
\hline Canguaretama & 111.869 .000 & 18.382 .548 & $16,4 \%$ \\
\hline Caraúbas & 126.034 .000 & 20.551 .590 & $16,3 \%$ \\
\hline Carnaúba dos Dantas & 27.525 .000 & 2.986 .707 & $10,8 \%$ \\
\hline Carnaubais & 64.032 .000 & 1.326 .233 & $2,07 \%$ \\
\hline Ceará-Mirim & 276.861 .000 & 45.914 .773 & $16,5 \%$ \\
\hline Cerro Corá & 39.352 .000 & 6.018 .310 & $15,2 \%$ \\
\hline Coronel Ezequiel & 19.476 .000 & 2.843 .332 & $14,6 \%$ \\
\hline Coronel João Pessoa & 16.474 .000 & 2.708 .736 & $16,4 \%$ \\
\hline
\end{tabular}




\begin{tabular}{|c|c|c|c|}
\hline Cruzeta & 38.919 .000 & 3.656 .672 & $9,4 \%$ \\
\hline Currais Novos & 230.391 .000 & 55.833 .768 & $24,2 \%$ \\
\hline Doutor Severiano & 21.730 .000 & 4.105 .554 & $18,8 \%$ \\
\hline Encanto & 19.443 .000 & 3.739 .829 & $19,2 \%$ \\
\hline Equador & 21.991 .000 & 2.911 .886 & $13,2 \%$ \\
\hline Espírito Santo & 31.109 .000 & 2.714 .030 & $8,7 \%$ \\
\hline Extremoz & 331.343 .000 & 1.820 .207 & $0,5 \%$ \\
\hline Felipe Guerra & 73.651 .000 & 2.385 .045 & $3,2 \%$ \\
\hline Fernando Pedroza & 10.651 .000 & 214.719 & $2,0 \%$ \\
\hline Florânia & 31.586 .000 & 8.918 .289 & $28,2 \%$ \\
\hline Francisco Dantas & 12.358 .000 & 1.037 .172 & $8,3 \%$ \\
\hline Frutuoso Gomes & 16.500 .000 & 2.943 .547 & $17,8 \%$ \\
\hline Galinhos & 24.788 .000 & 150.340 & $0,6 \%$ \\
\hline Goianinha & 98.913 .000 & 19.170 .987 & $19,3 \%$ \\
\hline Governador Dix-Sept Rosado & 115.909 .000 & 10.157 .883 & $8,7 \%$ \\
\hline Grossos & 96.995 .000 & 260.966 & $0,2 \%$ \\
\hline Guamaré & 886.914 .000 & 3.793 .084 & $0,4 \%$ \\
\hline Ielmo Marinho & 58.299 .000 & 2.741 .508 & $4,7 \%$ \\
\hline Ipanguaçu & 58.874 .000 & 10.480 .705 & $17,8 \%$ \\
\hline Ipueira & 10.149 .000 & 637.310 & $6,2 \%$ \\
\hline Itajá & 25.080 .000 & 885.875 & $3,5 \%$ \\
\hline Itaú & 21.136 .000 & 1.280 .937 & $6,0 \%$ \\
\hline Jaçanã & 24.860 .000 & 4.009 .562 & $16,1 \%$ \\
\hline Jandaíra & 22.226 .000 & 1.733 .291 & $7,8 \%$ \\
\hline Janduís & 17.373 .000 & 2.822 .351 & $16,2 \%$ \\
\hline Januário Cicco & 36.938 .000 & 2.122 .459 & $5,7 \%$ \\
\hline Japi & 17.413 .000 & 2.407 .704 & $13,8 \%$ \\
\hline Jardim de Angicos & 10.004 .000 & 485.318 & $4,8 \%$ \\
\hline Jardim de Piranhas & 55.105 .000 & 5.007 .308 & $9,1 \%$ \\
\hline Jardim do Seridó & 55.671 .000 & 13.022 .488 & $23,3 \%$ \\
\hline João Câmara & 115.560 .000 & 32.788 .936 & $28,3 \%$ \\
\hline João Dias & 10.289 .000 & 1.633 .880 & $15,8 \%$ \\
\hline José da Penha & 23.122 .000 & 5.777 .502 & $24,9 \%$ \\
\hline Jucurutu & 83.719 .000 & 15.410 .283 & $18,4 \%$ \\
\hline Jundiá & 12.607 .000 & 302.687 & $2,4 \%$ \\
\hline Lagoa d'Anta & 23.522 .000 & 2.215 .748 & $9,4 \%$ \\
\hline Lagoa de Pedras & 24.132 .000 & 2.822 .375 & $11,7 \%$ \\
\hline
\end{tabular}




\begin{tabular}{|c|c|c|c|}
\hline Lagoa de Velhos & 13.175 .000 & 672.763 & $5,1 \%$ \\
\hline Lagoa Nova & 42.867 .000 & 4.845 .719 & $11,3 \%$ \\
\hline Lagoa Salgada & 30.583 .000 & 3.107 .360 & $10,1 \%$ \\
\hline Lajes & 38.188 .000 & 8.604 .149 & $22,5 \%$ \\
\hline Lajes Pintadas & 16.085 .000 & 2.584 .007 & $16,0 \%$ \\
\hline Lucrecia & 13.575 .000 & 2.520 .722 & $18,5 \%$ \\
\hline Luís Gomes & 31.629 .000 & 7.418 .449 & $23,4 \%$ \\
\hline Macaíba & 576.110 .000 & 34.595 .224 & $6,0 \%$ \\
\hline Macau & 375.999 .000 & 35.148 .605 & $9,3 \%$ \\
\hline Major Sales & 13.083 .000 & 2.930 .905 & $22,4 \%$ \\
\hline Marcelino Vieira & 30.050 .000 & 6.533 .647 & $21,7 \%$ \\
\hline Martins & 28.653 .000 & 11.035 .296 & $38,5 \%$ \\
\hline Maxaranguape & 39.658 .000 & 1.256 .553 & $3,1 \%$ \\
\hline Messias Targino & 16.391 .000 & 2.378 .982 & $14,5 \%$ \\
\hline Montanhas & 39.060 .000 & 3.581 .071 & $9,1 \%$ \\
\hline Monte Alegre & 73.054 .000 & 14.553 .118 & $19,9 \%$ \\
\hline Monte das Gameleiras & 9.899 .000 & 1.145 .688 & $11,5 \%$ \\
\hline Mossoró & 2.676 .568 .000 & 204.921 .182 & $7,6 \%$ \\
\hline Natal & 8.022 .875 .000 & 679.113 .691 & $8,4 \%$ \\
\hline Nísia Floresta & 101.691 .000 & 3.992 .038 & $3,9 \%$ \\
\hline Nova Cruz & 139.305 .000 & 38.908 .125 & $27,9 \%$ \\
\hline Olho-d'Água do Borges & 15.728 .000 & 2.724 .205 & $17,3 \%$ \\
\hline Ouro Branco & 25.589 .000 & 3.243 .467 & $12,6 \%$ \\
\hline Paraná & 14.328 .000 & 3.438 .052 & $24,0 \%$ \\
\hline Paraú & 13.447 .000 & 798.550 & $5,9 \%$ \\
\hline Parazinho & 19.332 .000 & 1.693 .188 & $8,7 \%$ \\
\hline Parelhas & 86.403 .000 & 17.876 .297 & $20,6 \%$ \\
\hline Parnamirim & 1.402 .947 .000 & 97.154 .399 & $6,9 \%$ \\
\hline Passa e Fica & 37.219 .000 & 5.153 .801 & $13,8 \%$ \\
\hline Passagem & 11.579 .000 & 249.959 & $2,1 \%$ \\
\hline Patu & 42.551 .000 & 16.233 .224 & $38,1 \%$ \\
\hline Pau dos Ferros & 148.566 .000 & 43.307 .095 & $29,1 \%$ \\
\hline Pedra Grande* & 17.766 .000 & 951.777 & $5,3 \%$ \\
\hline Pedra Preta & 10.697 .000 & 1.162 .336 & $10,8 \%$ \\
\hline Pedro Avelino & 24.731 .000 & 5.067 .122 & $20,4 \%$ \\
\hline Pedro Velho & 47.448 .000 & 3.193 .637 & $6,7 \%$ \\
\hline Pendências & 114.689 .000 & 3.566 .585 & $3,1 \%$ \\
\hline
\end{tabular}




\begin{tabular}{|c|c|c|c|}
\hline Pilões & 13.179 .000 & 2.466 .288 & $18,7 \%$ \\
\hline Poço Branco & 41.448 .000 & 1.266 .754 & $3,0 \%$ \\
\hline Portalegre & 22.542 .000 & 5.566 .176 & $24,6 \%$ \\
\hline Porto do Mangue & 151.286 .000 & 46.612 & $0,03 \%$ \\
\hline Presidente Juscelino & 29.562 .000 & 3.487 .509 & $11,8 \%$ \\
\hline Pureza & 35.314 .000 & 321.346 & $0,9 \%$ \\
\hline Rafael Fernandes & 18.732 .000 & 2.972 .438 & $15,8 \%$ \\
\hline Rafael Godeiro & 12.897 .000 & 2.642 .921 & $20,4 \%$ \\
\hline Riacho da Cruz & 11.360 .000 & 1.331 .988 & $11,7 \%$ \\
\hline Riacho de Santana & 16.613 .000 & 3.315 .338 & $19,9 \%$ \\
\hline Riachuelo & 24.718 .000 & 1.596 .125 & $6,4 \%$ \\
\hline Rio do Fogo & 35.535 .000 & 1.432 .211 & $4,0 \%$ \\
\hline Rodolfo Fernandes & 17.090 .000 & 2.354 .349 & $13,7 \%$ \\
\hline Ruy Barbosa & 13.482 .000 & 1.672 .317 & $12,4 \%$ \\
\hline Santa Cruz & 133.295 .000 & 63.242 .343 & $47,4 \%$ \\
\hline Santa Maria & 18.424 .000 & 729.143 & $3,9 \%$ \\
\hline Santana do Matos & 53.315 .000 & 11.870 .959 & $22,2 \%$ \\
\hline Santana do Seridó & 11.343 .000 & 468.829 & $4,1 \%$ \\
\hline Santo Antônio & 73.863 .000 & 26.384 .359 & $35,7 \%$ \\
\hline São Bento do Norte & 22.141 .000 & 2.374 .790 & $10,7 \%$ \\
\hline São Bento do Trairí & 13.826 .000 & 1.434 .238 & $10,3 \%$ \\
\hline São Fernando & 26.698 .000 & 1.954 .491 & $7,3 \%$ \\
\hline São Francisco do Oeste & 15.158 .000 & 2.558 .935 & $16,8 \%$ \\
\hline São Gonçalo do Amarante & 612.729 .000 & 42.905 .339 & $7,00 \%$ \\
\hline São João do Sabugi & 24.317 .000 & 3.628 .438 & $14,9 \%$ \\
\hline São José de Mipibu & 174.048 .000 & 21.876 .512 & $12,5 \%$ \\
\hline São José do Campestre & 42.402 .000 & 9.861 .496 & $23,2 \%$ \\
\hline São José do Seridó & 24.066 .000 & 2.389 .889 & $9,9 \%$ \\
\hline São Miguel & 77.835 .000 & 28.712 .590 & $36,8 \%$ \\
\hline São Miguel do Gostoso & 42.267 .000 & 651.900 & $1,5 \%$ \\
\hline São Paulo do Potengi & 59.577 .000 & 15.003 .064 & $25,1 \%$ \\
\hline São Pedro & 23.803 .000 & 2.387 .732 & $10,0 \%$ \\
\hline São Rafael & 32.068 .000 & 4.582 .605 & $14,2 \%$ \\
\hline São Tomé & 35.611 .000 & 6.525 .014 & $18,3 \%$ \\
\hline São Vicente & 20.421 .000 & 3.197 .510 & $15,6 \%$ \\
\hline Senador Eloi de Souza & 20.848 .000 & 1.779 .790 & $8,5 \%$ \\
\hline Senador Georgino Avelino & 18.418 .000 & 782.560 & $4,2 \%$ \\
\hline
\end{tabular}




\begin{tabular}{|c|c|c|c|}
\hline Serra de São Bento & 16.565 .000 & 2.991 .629 & $18,0 \%$ \\
\hline Serra do Mel & 55.055 .000 & 197.975 & $0,3 \%$ \\
\hline Serra Negra do Norte & 31.530 .000 & 5.495 .052 & $17,4 \%$ \\
\hline Serrinha & 35.979 .000 & 2.977 .962 & $8,2 \%$ \\
\hline Serrinha dos Pintos & 15.437 .000 & 1.803 .026 & $11,6 \%$ \\
\hline Severiano Melo & 25.764 .000 & 2.783 .692 & $10,8 \%$ \\
\hline Sítio Novo & 18.068 .000 & 1.495 .712 & $8,2 \%$ \\
\hline Taboleiro Grande & 9.888 .000 & 637.506 & $6,4 \%$ \\
\hline Taipu & 53.859 .000 & 1.401 .175 & $2,6 \%$ \\
\hline Tangará & 50.376 .000 & 5.092 .930 & $10,1 \%$ \\
\hline Tenente Ananias & 31.689 .000 & 7.065 .358 & $22,3 \%$ \\
\hline Tenente Laurentino Cruz & 19.232 .000 & 2.183 .409 & $11,3 \%$ \\
\hline Tibau** & 32.383 .000 & 45.229 & $0,1 \%$ \\
\hline Tibau do Sul & 58.174 .000 & 1.765 .864 & $3,0 \%$ \\
\hline Timbaúba dos Batistas & 9.648 .000 & 1.505 .342 & $15,6 \%$ \\
\hline Touros & 160.111 .000 & 18.408 .884 & $11,5 \%$ \\
\hline Triunfo Potiguar & 13.342 .000 & 517.310 & $3,8 \%$ \\
\hline Umarizal & 43.807 .000 & 13.989 .670 & $31,9 \%$ \\
\hline Upanema & 71.107 .000 & 3.017 .009 & $4,2 \%$ \\
\hline Várzea & 17.892 .000 & 2.789 .790 & $15,5 \%$ \\
\hline Venha-Ver & 13.237 .000 & 1.746 .549 & $13,1 \%$ \\
\hline Vera Cruz & 40.006 .000 & 4.296 .030 & $10,7 \%$ \\
\hline Viçosa & 8.379 .000 & 817.897 & $9,7 \%$ \\
\hline Vila Flor* & 12.423 .000 & 148.650 & $1,2 \%$ \\
\hline
\end{tabular}

FONTE: PIB Municipal - IBGE. Valores dos benefícios previdenciários - SINTESE/DATAPREV. IDH-M - PNUD/ONU.

Notas:

(1) Foram excluídos os centavos e na coluna (A) os valores foram arredondados.

(2) O Valor dos benefícios emitidos corresponde ao valor líquido (diferença entre valor bruto e descontos) dos créditos emitidos pelo Instituto Nacional de Previdência Social - INSS para pagamento de benefícios do Regime Geral de Previdência Social, Encargos Previdenciários da União e Amparos Assistenciais previstos na Lei Orgânica da Assistência Social, classificados pelo município do órgão pagador. 
ANEXO I

VALOR ANUAL DOS BENEFÍCIOS EMITIDOS PELO INSS, SEGUNDO OS MUNICÍPIOS DO ESTADO DO RIO GRANDE DO NORTE - 2000 A 2009

\begin{tabular}{|c|c|c|c|c|c|c|c|c|c|c|c|}
\hline \multirow[t]{2}{*}{$\begin{array}{l}\text { CÓDIGO } \\
\text { IBGE }\end{array}$} & \multirow[t]{2}{*}{ MUNICÍPIO } & \multicolumn{10}{|c|}{$\begin{array}{c}\text { VALOR DOS BENEFÍCIOS EMITIDOS } \\
\text { NO ANO }\end{array}$} \\
\hline & & 2000 & 2001 & 2002 & 2003 & 2004 & 2005 & 2006 & 2007 & 2008 & 2009 \\
\hline 2400109 & Acari & 4.106 .835 & 4.824 .857 & 5.407 .351 & 6.369 .557 & 6.899 .329 & 7.541 .824 & 8.446 .604 & 9.244 .245 & 10.190 .511 & 11.605 .451 \\
\hline 2400208 & Açu & 15.049 .656 & 17.598 .122 & 20.724 .624 & 29.465 .802 & 38.029 .715 & 47.259 .449 & 59.062 .041 & 67.335 .336 & 72.339 .586 & 80.748 .417 \\
\hline 2400307 & Afonso Bezerra & 2.894 .753 & 3.497 .772 & 4.073 .692 & 4.923 .436 & 5.543 .521 & 5.922 .036 & 6.730 .477 & 7.285.077 & 7.923 .380 & 8.977 .647 \\
\hline 2400406 & Água Nova & 635.940 & 734.548 & 857.599 & 1.053 .828 & 1.266 .947 & 1.572 .739 & 1.679 .642 & 1.753 .967 & 1.885 .019 & 2.178 .972 \\
\hline 2400505 & Alexandria & 6.268 .787 & 7.570 .137 & 8.768 .612 & 10.857 .252 & 12.502 .868 & 14.544 .906 & 17.078.201 & 19.047 .849 & 20.609 .919 & 23.103 .662 \\
\hline 2400604 & Almino Afonso & 1.412 .183 & 1.672 .372 & 1.920 .987 & 2.202 .746 & 2.458 .680 & 2.756 .397 & 2.739 .379 & 3.063 .143 & 3.536 .557 & 4.192 .172 \\
\hline 2400703 & Alto do Rodrigues & 1.891 .613 & 2.212 .113 & 2.739 .975 & 3.469 .938 & 3.929 .561 & 4.212 .483 & 4.280 .733 & 3.881 .883 & 4.375 .447 & 5.514 .460 \\
\hline 2400802 & Angicos & 4.526 .530 & 5.116 .329 & 5.844 .873 & 6.843 .337 & 7.570 .748 & 8.154 .506 & 9.073 .200 & 9.686 .196 & 10.485 .245 & 11.975 .065 \\
\hline 2400901 & Antônio Martins & 2.120 .990 & 2.575 .258 & 3.022 .720 & 3.453 .856 & 4.148 .246 & 5.191 .878 & 5.431 .499 & 5.584 .836 & 6.162 .022 & 7.282 .754 \\
\hline 2401008 & Apodi & 10.422 .552 & 12.527 .619 & 14.739 .636 & 18.475 .488 & 21.418 .686 & 25.106 .259 & 29.153 .803 & 31.925 .159 & 34.739 .460 & 39.725 .586 \\
\hline 2401107 & Areia Branca & 20.309 .799 & 21.066 .530 & 24.481 .351 & 29.083 .801 & 33.992 .102 & 34.475 .864 & 38.608 .475 & 39.318 .366 & 40.954 .837 & 46.429 .361 \\
\hline 2401206 & Arês & 2.158 .833 & 2.492 .652 & 2.909 .661 & 3.376 .257 & 3.576 .475 & 3.501 .716 & 3.296 .447 & 3.335 .717 & 3.943 .959 & 4.936 .137 \\
\hline 2401305 & Augusto severo & 5.411 .788 & 6.216 .658 & 7.007.612 & 8.559 .676 & 9.506 .567 & 10.605 .011 & 12.222 .244 & 13.236 .781 & 14.371 .222 & 16.414 .613 \\
\hline 2401404 & Baía Formosa & 1.178 .986 & 1.335 .903 & 1.553 .856 & 1.804 .999 & 1.746 .259 & 1.789 .982 & 1.785 .364 & 1.911 .060 & 2.138 .301 & 2.237 .108 \\
\hline 2401453 & Baraúna & 3.411 .859 & 4.269 .159 & 5.146 .441 & 6.579 .806 & 7.532 .835 & 8.217 .712 & 9.504 .250 & 11.041 .586 & 12.652 .087 & 14.943 .183 \\
\hline 2401503 & Barcelona & 1.145 .757 & 1.300 .921 & 1.414 .620 & 1.618 .499 & 1.728 .571 & 1.779 .453 & 1.823 .065 & 2.026 .675 & 2.362 .262 & 2.775 .510 \\
\hline 2401602 & Bento Fernandes & 1.183 .076 & 1.399 .340 & 1.572 .169 & 1.905 .896 & 1.934 .268 & 1.893 .380 & 1.960 .202 & 1.914 .308 & 1.962 .567 & 2.186 .815 \\
\hline 2401651 & Bodó & 102.991 & 389.874 & 456.878 & 385.223 & 78.756 & 115.781 & 159.253 & 271.319 & 372.667 & 514.996 \\
\hline 2401701 & Bom Jesus & 2.290 .212 & 2.755 .031 & 3.165 .264 & 3.669 .829 & 3.326 .608 & 3.417 .501 & 3.825 .371 & 4.174 .001 & 4.669 .004 & 5.273 .530 \\
\hline 2401800 & Brejinho & 1.573 .026 & 1.792 .697 & 1.927 .565 & 2.287 .631 & 2.311 .344 & 2.473 .327 & 2.645 .039 & 2.863 .892 & 3.639 .933 & 4.729 .699 \\
\hline 2401859 & Caiçara do Norte & 0 & 0 & 0 & 25.081 & 303.976 & 304.780 & 321.199 & 374.709 & 452.068 & 459.478 \\
\hline 2401909 & $\begin{array}{l}\text { Caiçara do Rio do } \\
\text { Vento }\end{array}$ & 767.965 & 929.439 & 1.065 .703 & 1.218 .587 & 1.194 .958 & 1.212 .469 & 1.209 .607 & 1.335 .959 & 1.480 .958 & 1.684 .839 \\
\hline 2402006 & Caicó & 19.201 .586 & 22.115 .972 & 25.945 .000 & 33.664 .627 & 40.682 .874 & 47.681 .580 & 57.551 .549 & 63.932 .235 & 69.438 .503 & 78.677 .627 \\
\hline 2402105 & Campo Redondo & 3.293 .697 & 3.905 .664 & 4.353 .014 & 4.653 .788 & 4.790 .672 & 4.965 .052 & 5.354 .724 & 5.965 .239 & 6.712 .589 & 7.852 .101 \\
\hline
\end{tabular}




\begin{tabular}{|c|c|c|c|c|c|c|c|c|c|c|c|}
\hline 2402204 & Canguaretama & 7.900 .727 & 9.176 .190 & 10.270 .735 & 12.215 .914 & 13.943 .705 & 15.566 .862 & 17.484 .221 & 18.382 .548 & 19.905 .885 & 22.593 .188 \\
\hline 2402303 & Caraúbas & 7.319 .956 & 8.847 .204 & 10.365 .808 & 12.730 .717 & 14.301 .583 & 16.193 .747 & 18.725 .580 & 20.551 .590 & 22.709 .881 & 25.864 .365 \\
\hline 2402402 & Carnaúba dos Dantas & 0 & 0 & 0 & 110.733 & 547.945 & 1.227 .296 & 1.938 .561 & 2.986 .707 & 3.616 .459 & 4.475 .384 \\
\hline 2402501 & Carnaubais & 1.722 .604 & 2.038 .686 & 2.349 .737 & 2.363 .088 & 1.602 .329 & 1.274 .222 & 1.108 .058 & 1.326 .233 & 1.628 .269 & 2.212 .443 \\
\hline 2402600 & Ceará-Mirim & 15.854 .810 & 18.727 .705 & 21.310 .808 & 26.124 .602 & 30.289 .615 & 34.285 .310 & 40.560 .888 & 45.914 .773 & 50.493 .906 & 58.174 .042 \\
\hline 2402709 & Cerro Corá & 3.040 .926 & 3.545 .577 & 4.041 .886 & 4.793 .931 & 4.611 .287 & 5.029 .776 & 5.623 .063 & 6.018 .310 & 6.706 .161 & 7.933 .656 \\
\hline 2402808 & Coronel Ezequiel & 1.802 .757 & 2.092 .201 & 1.912 .778 & 1.036 .019 & 1.921 .154 & 2.235 .660 & 2.526 .238 & 2.843 .332 & 3.275 .941 & 4.000 .560 \\
\hline 2402907 & Coronel João Pessoa & 1.200 .801 & 1.376 .928 & 1.684 .669 & 1.935 .203 & 2.389 .580 & 2.888 .137 & 2.866 .808 & 2.708 .736 & 2.859 .645 & 3.270 .394 \\
\hline 2403004 & Cruzeta & 1.683 .886 & 1.986 .478 & 2.215 .488 & 2.415 .897 & 2.626 .976 & 2.924 .744 & 3.290 .365 & 3.656 .672 & 4.183 .560 & 5.033 .961 \\
\hline 2403103 & Currais Novos & 17.438 .412 & 19.913 .397 & 23.164 .833 & 30.456 .219 & 37.798 .901 & 44.073 .103 & 51.242 .558 & 55.833 .768 & 59.983 .688 & 67.410 .869 \\
\hline 2403202 & Doutor Severiano & 1.417 .828 & 1.731 .554 & 2.064 .703 & 2.483 .282 & 2.928 .725 & 3.594 .990 & 4.089 .065 & 4.105 .554 & 4.352 .510 & 4.957 .588 \\
\hline 2403301 & Encanto & 1.536 .520 & 1.780 .435 & 2.078 .234 & 2.574 .547 & 3.041 .733 & 3.565 .799 & 3.678 .995 & 3.739 .829 & 3.903 .593 & 4.512 .570 \\
\hline 2403400 & Equador & 1.555 .781 & 1.836 .116 & 2.113 .889 & 2.218 .444 & 2.440 .580 & 2.774 .614 & 2.693 .635 & 2.911 .886 & 3.295 .167 & 3.794 .604 \\
\hline 2403509 & Espírito Santo & 2.157 .497 & 2.610 .214 & 3.000 .405 & 3.471 .074 & 3.461 .922 & 3.278 .899 & 3.044 .510 & 2.714 .030 & 3.206 .510 & 3.883 .021 \\
\hline 2403608 & Extremoz & 1.609 .596 & 1.909 .155 & 2.062 .348 & 2.256 .774 & 2.170 .283 & 1.969 .861 & 1.720 .062 & 1.820 .207 & 2.217 .696 & 2.392 .538 \\
\hline 2403707 & Felipe Guerra & 2.036 .707 & 2.454 .305 & 2.797 .591 & 2.709 .513 & 2.605 .349 & 2.724 .044 & 2.541 .739 & 2.385 .045 & 2.873 .499 & 3.558 .603 \\
\hline 2403756 & Fernando Pedroza & 138.005 & 445.605 & 546.798 & 591.904 & 557.351 & 466.676 & 230.502 & 214.719 & 308.529 & 478.885 \\
\hline 2403806 & Florânia & 3.787 .805 & 4.013 .400 & 4.573 .828 & 5.618 .067 & 6.261 .226 & 6.891 .988 & 8.071 .834 & 8.918 .289 & 9.937 .122 & 11.661 .521 \\
\hline 2403905 & Francisco Dantas & 673.755 & 803.032 & 957.232 & 1.222 .512 & 1.355 .372 & 1.582 .944 & 1.241 .668 & 1.037 .172 & 1.127 .340 & 1.288 .203 \\
\hline 2404002 & Frutuoso Gomes & 1.334 .573 & 1.651 .342 & 1.906 .867 & 2.212 .508 & 2.489 .393 & 2.796 .614 & 2.944 .459 & 2.943 .547 & 3.242 .832 & 3.933 .209 \\
\hline 2404101 & Galinhos & 218.322 & 256.647 & 240.656 & 156.329 & 134.848 & 132.912 & 131.994 & 150.340 & 190.461 & 251.461 \\
\hline 2404200 & Goianinha & 6.746 .271 & 7.836 .572 & 9.052 .099 & 11.247.371 & 13.198 .645 & 14.674 .402 & 17.311 .181 & 19.170 .987 & 21.360 .897 & 24.388 .081 \\
\hline 2404309 & $\begin{array}{c}\text { Governador Dix-Sept } \\
\text { Rosado }\end{array}$ & 3.231 .677 & 3.874 .889 & 4.729 .436 & 6.030 .406 & 6.809 .781 & 7.737 .265 & 8.979 .572 & 10.157 .883 & 11.465 .782 & 13.333 .667 \\
\hline 2404408 & Grossos & 1.322 .373 & 1.405 .772 & 1.340 .340 & 1.093 .093 & 861.364 & 785.879 & 510.867 & 260.966 & 300.402 & 371.280 \\
\hline 2404507 & Guamaré & 1.102 .837 & 1.265 .603 & 1.497 .506 & 1.749 .472 & 1.961 .793 & 2.709 .107 & 3.342 .910 & 3.793 .084 & 4.239 .935 & 5.142 .986 \\
\hline 2404606 & Ielmo Marinho & 2.065 .995 & 2.466 .261 & 2.647 .892 & 2.749 .181 & 2.900 .817 & 2.971 .532 & 2.864 .174 & 2.741 .508 & 3.068 .997 & 3.480 .933 \\
\hline 2404705 & Ipanguaçu & 3.705 .152 & 4.364 .864 & 5.119 .267 & 6.348 .403 & 7.086 .044 & 7.671 .230 & 9.112 .241 & 10.480 .705 & 11.652 .656 & 13.250 .471 \\
\hline 2404804 & Ipueira & 512.295 & 671.161 & 741.767 & 756.832 & 813.224 & 935.184 & 780.948 & 637.310 & 754.014 & 923.644 \\
\hline 2404853 & Itajá & 63.332 & 252.567 & 319.961 & 267.486 & 420.835 & 503.475 & 701.407 & 885.875 & 1.145 .571 & 1.580 .147 \\
\hline 2404903 & Itaú & 1.369 .434 & 1.702 .352 & 1.999 .883 & 2.274 .313 & 2.319 .297 & 2.477 .157 & 2.053 .446 & 1.280 .937 & 1.541 .328 & 1.949 .647 \\
\hline 2405009 & Jaçanã & 2.050 .603 & 2.452 .293 & 2.802 .873 & 3.300 .585 & 3.416 .538 & 3.558 .764 & 3.737 .824 & 4.009 .562 & 4.489 .811 & 5.189 .972 \\
\hline 2405108 & Jandaíra & 1.531 .404 & 1.771 .120 & 1.801 .539 & 1.671 .395 & 1.562 .999 & 1.511 .736 & 1.521 .530 & 1.733 .291 & 1.998 .797 & 2.350 .951 \\
\hline 2405207 & Janduís & 850.688 & 1.028 .277 & 1.309 .447 & 1.623 .532 & 1.832 .507 & 2.193 .422 & 2.432 .329 & 2.822 .351 & 3.132 .884 & 3.625 .295 \\
\hline 2405306 & Januário Cicco & 2.123 .228 & 2.535 .928 & 2.850 .991 & 3.056 .774 & 2.822 .553 & 2.459 .890 & 1.996 .866 & 2.122 .459 & 2.601 .001 & 3.301 .247 \\
\hline 2405405 & Japi & 1.195 .751 & 1.387 .689 & 1.752 .795 & 2.063 .701 & 2.229 .437 & 2.340 .513 & 2.391 .916 & 2.407 .704 & 2.732 .220 & 3.235 .402 \\
\hline 2405504 & Jardim de Angicos & 541.341 & 641.656 & 746.800 & 896.792 & 846.583 & 681.581 & 389.861 & 485.318 & 533.383 & 559.284 \\
\hline 2405603 & Jardim de Piranhas & 1.675 .639 & 2.131 .560 & 2.531 .807 & 2.904 .056 & 3.198 .718 & 3.712 .021 & 4.486 .163 & 5.007 .308 & 5.696 .939 & 6.821 .483 \\
\hline 2405702 & Jardim do Seridó & 4.695 .844 & 5.459 .285 & 6.307 .597 & 7.508 .733 & 8.418 .027 & 9.592 .733 & 11.443 .402 & 13.022 .488 & 14.488 .030 & 16.693 .268 \\
\hline 2405801 & João Câmara & 10.252 .762 & 12.204 .731 & 14.737.677 & 18.352 .297 & 21.526 .323 & 24.834 .352 & 28.744 .590 & 32.788 .936 & 37.784 .122 & 45.837 .291 \\
\hline 2405900 & João Dias & 805.967 & 973.984 & 1.074 .988 & 1.170 .301 & 1.351 .006 & 1.636 .418 & 1.577 .935 & 1.633 .880 & 1.799 .698 & 2.169 .467 \\
\hline
\end{tabular}




\begin{tabular}{l|}
2406007 \\
2406106 \\
2406155 \\
2406205 \\
2406304 \\
2406403 \\
2406502 \\
2406601 \\
2406700 \\
2406809 \\
2406908 \\
2407005 \\
2407104 \\
2407203 \\
2407252 \\
2407302 \\
2407401 \\
2407500 \\
2407609 \\
2407708 \\
2407807 \\
2407906 \\
2408003 \\
2408102 \\
2408201 \\
2408300 \\
2408409 \\
2408508 \\
2408607 \\
2408706 \\
2408805 \\
2408904 \\
2403251 \\
2409100 \\
2409209 \\
2409308 \\
2409407 \\
2409506 \\
2409605 \\
2409704
\end{tabular}

\begin{tabular}{c|c|c|} 
José da Penha & 2.194 .708 & 2.613 .131 \\
Jucurutu & 5.555 .134 & 6.614 .158 \\
Jundiá & 0 & 0 \\
Lagoa d'Anta & 1.045 .635 & 1.289 .861 \\
Lagoa de Pedras & 1.336 .990 & 1.656 .771 \\
Lagoa de Velhos & 516.994 & 634.356 \\
Lagoa Nova & 3.166 .333 & 3.749 .318 \\
Lagoa Salgada & 1.865 .580 & 2.235 .470 \\
Lajes & 3.418 .120 & 4.020 .636 \\
Lajes Pintadas & 1.193 .496 & 1.428 .595 \\
Lucrécia & 975.876 & 1.208 .079 \\
Luís Gomes & 3.556 .966 & 3.424 .790 \\
Macaíba & 12.418 .317 & 14.797 .919 \\
Macau & 15.966 .760 & 18.326 .584 \\
Major Sales & 179.271 & 1.011 .249 \\
Marcelino Vieira & 2.731 .286 & 3.243 .850 \\
Martins & 4.451 .527 & 5.014 .272 \\
Maxaranguape & 1.140 .097 & 1.091 .064 \\
Messias Targino & 1.000 .624 & 1.205 .359 \\
Montanhas & 1.810 .152 & 2.071 .929 \\
Monte Alegre & 4.357 .543 & 5.317 .417 \\
Monte das Gameleiras & 570.396 & 681.081 \\
Mossoró & 68.910 .707 & 80.577 .031 \\
Natal & 274.350 .577 & 315.169 .207 \\
Nísia Floresta & 1.877 .181 & 2.248 .194 \\
Nova Cruz & 11.980 .828 & 14.325 .273 \\
Olho-d'Água do & 1.211 .086 & 1.486 .168 \\
Borges & & \\
Ouro Branco & 1.578 .357 & 1.829 .127 \\
Paraná & 1.049 .787 & 1.284 .846 \\
Paraú & 879.065 & 1.046 .338 \\
Parazinho & 1.186 .552 & 1.412 .005 \\
Parelhas & 8.084 .632 & 9.493 .921 \\
Parnamirim & 16.061 .919 & 19.149 .553 \\
Passa e Fica & 2.200 .989 & 2.704 .340 \\
Passagem & 510.112 & 610.561 \\
Patu & 5.088 .537 & 6.085 .427 \\
Pau dos Ferros & 9.255 .295 & 10.936 .269 \\
Pedra Grande & 1.016 .100 & 1.184 .646 \\
Pedra Preta & 733.051 & 847.348 \\
Pedro Avelino & 2.016 .980 & 2.396 .965 \\
Para & &
\end{tabular}

\begin{tabular}{c}
3.036 .386 \\
7.752 .603 \\
0 \\
1.526 .836 \\
1.981 .989 \\
763.189 \\
4.029 .353 \\
2.488 .446 \\
4.597 .832 \\
1.665 .996 \\
1.443 .846 \\
3.941 .226 \\
16.969 .476 \\
20.963 .369 \\
1.306 .346 \\
3.766 .722 \\
5.714 .298 \\
1.162 .570 \\
1.429 .505 \\
2.300 .649 \\
6.583 .526 \\
809.915 \\
93.526 .496 \\
360.863 .148 \\
2.596 .254 \\
16.857 .776 \\
1.583 .566 \\
\\
2.117 .962 \\
1.555 .981 \\
1.043 .481 \\
1.520 .463 \\
11.002 .627 \\
23.567 .595 \\
3.107 .544 \\
731.963 \\
6.951 .046 \\
12.545 .290 \\
1.276 .594 \\
929.400 \\
2.744 .753 \\
\hline
\end{tabular}

\begin{tabular}{|c|}
3.759 .846 \\
9.447 .747 \\
119.538 \\
1.560 .565 \\
2.298 .944 \\
734.981 \\
4.114 .042 \\
2.573 .717 \\
5.669 .154 \\
2.038 .938 \\
1.796 .650 \\
4.700 .427 \\
20.726 .290 \\
24.928 .833 \\
1.601 .838 \\
4.509 .934 \\
6.913 .966 \\
1.363 .341 \\
1.793 .639 \\
2.514 .030 \\
8.195 .975 \\
862.998 \\
118.943 .291 \\
435.919 .931 \\
2.943 .884 \\
20.856 .236 \\
1.417 .692 \\
\\
2.514 .525 \\
1.875 .129 \\
523.475 \\
1.822 .142 \\
13.335 .406 \\
34.509 .105 \\
3.612 .635 \\
745.000 \\
8.520 .837 \\
15.596 .359 \\
1.518 .102 \\
1.056 .654 \\
3.321 .726
\end{tabular}

\begin{tabular}{c|c}
4.378 .410 & 5.204 .599 \\
10.394 .309 & 11.615 .963 \\
253.680 & 283.156 \\
1.822 .466 & 2.205 .354 \\
2.337 .485 & 2.465 .966 \\
695.468 & 670.666 \\
4.057 .743 & 4.336 .148 \\
2.043 .111 & 2.194 .904 \\
6.644 .774 & 7.137 .768 \\
2.004 .145 & 2.121 .916 \\
2.029 .204 & 2.263 .579 \\
5.540 .376 & 6.825 .145 \\
23.612 .834 & 27.181 .374 \\
28.164 .743 & 31.032 .327 \\
1.892 .720 & 2.329 .690 \\
5.104 .294 & 5.696 .542 \\
7.697 .809 & 8.789 .173 \\
1.421 .258 & 1.340 .804 \\
2.043 .369 & 2.290 .234 \\
2.816 .939 & 3.132 .630 \\
9.497 .525 & 10.994 .550 \\
870.818 & 899.427 \\
140.524 .056 & 161.368 .519 \\
500.420 .357 & 553.251 .862 \\
3.121 .239 & 3.344 .225 \\
25.400 .954 & 29.940 .155 \\
1.886 .593 & 2.354 .635 \\
& \\
2.523 .233 & 2.623 .545 \\
2.150 .736 & 2.754 .954 \\
618.988 & 715.057 \\
1.804 .044 & 1.649 .832 \\
14.283 .254 & 15.130 .720 \\
49.305 .528 & 65.680 .337 \\
4.379 .812 & 4.535 .725 \\
177.031 & 181.229 \\
9.755 .553 & 11.229 .866 \\
19.466 .041 & 25.327 .930 \\
954.831 & 888.829 \\
1.002 .857 & 981.484 \\
3.734 .900 & 4.126 .577 \\
& \\
\hline
\end{tabular}

\begin{tabular}{|c|}
5.658 .406 \\
13.781 .543 \\
301.705 \\
2.228 .650 \\
2.683 .705 \\
646.588 \\
4.559 .222 \\
2.559 .787 \\
8.008 .027 \\
2.339 .177 \\
2.376 .458 \\
7.357 .482 \\
31.827 .182 \\
34.944 .510 \\
2.693 .437 \\
6.231 .920 \\
10.097 .008 \\
1.230 .439 \\
2.316 .935 \\
3.393 .036 \\
13.204 .705 \\
1.024 .163 \\
184.985 .855 \\
620.887 .957 \\
3.549 .339 \\
35.841 .170 \\
2.549 .334 \\
2.948 .468 \\
3.225 .342 \\
766.261 \\
1.627 .337 \\
16.941 .486 \\
85.890 .688 \\
4.863 .713 \\
161.374 \\
13.930 .071 \\
35.281 .597 \\
836.646 \\
1.138 .959 \\
4.728 .287 \\
\hline
\end{tabular}

\begin{tabular}{c|c|c}
5.777 .502 & 6.048 .563 & 7.158 .797 \\
15.410 .283 & 16.982 .093 & 19.434 .963 \\
302.687 & 377.441 & 426.873 \\
2.215 .748 & 2.497 .755 & 2.983 .947 \\
2.822 .375 & 3.208 .108 & 3.918 .046 \\
672.763 & 840.814 & 1.060 .323 \\
4.845 .719 & 5.749 .864 & 7.109 .496 \\
3.107 .360 & 3.751 .845 & 4.796 .746 \\
8.604 .149 & 9.259 .737 & 10.486 .021 \\
2.584 .007 & 2.966 .516 & 3.535 .800 \\
2.520 .722 & 2.743 .977 & 3.413 .297 \\
7.418 .449 & 7.973 .156 & 9.606 .934 \\
34.595 .224 & 38.406 .257 & 43.336 .784 \\
35.148 .605 & 37.243 .959 & 42.221 .431 \\
2.930 .905 & 3.081 .495 & 3.666 .728 \\
6.533 .647 & 7.011 .282 & 8.014 .763 \\
11.035 .296 & 12.182 .737 & 13.750 .489 \\
1.256 .553 & 1.582 .344 & 2.023 .805 \\
2.378 .982 & 2.597 .455 & 3.118 .607 \\
3.581 .071 & 4.109 .022 & 4.767 .315 \\
14.553 .118 & 16.427 .797 & 19.144 .357 \\
1.145 .688 & 1.394 .115 & 1.629 .800 \\
204.921 .182 & 222.314 .176 & 251.370 .571 \\
679.113 .691 & 739.237 .678 & 839.569 .793 \\
3.992 .038 & 4.956 .229 & 6.225 .875 \\
38.908 .125 & 41.423 .138 & 46.619 .157 \\
2.724 .205 & 3.078 .727 & 3.605 .022 \\
& & \\
3.243 .467 & 3.711 .037 & 4.412 .135 \\
3.438 .052 & 3.584 .388 & 4.118 .095 \\
798.550 & 1.037 .995 & 1.402 .522 \\
1.693 .188 & 1.788 .457 & 2.134 .151 \\
17.876 .297 & 19.257 .507 & 21.542 .721 \\
97.154 .399 & 110.034 .513 & 129.220 .661 \\
5.153 .801 & 5.871 .654 & 7.178 .985 \\
249.959 & 431.220 & 539.966 \\
16.233 .224 & 17.773 .384 & 19.803 .814 \\
43.307 .095 & 48.151 .051 & 54.729 .114 \\
951.777 & 1.100 .038 & 1.225 .897 \\
1.162 .336 & 1.306 .316 & 1.534 .011 \\
5.067 .122 & 5.503 .506 & 6.320 .588
\end{tabular}




\begin{tabular}{|c|c|c|c|c|c|c|c|c|c|c|c|}
\hline 2409803 & Pedro Velho & 3.436 .041 & 3.945 .198 & 4.223 .136 & 4.295 .842 & 4.104 .012 & 4.203 .703 & 3.909 .591 & 3.193 .637 & 4.033 .309 & 5.507 .131 \\
\hline 2409902 & Pendências & 2.556 .853 & 2.863 .863 & 3.331 .961 & 3.817 .773 & 3.830 .272 & 3.717 .552 & 3.640 .829 & 3.566 .585 & 4.177 .792 & 5.255 .254 \\
\hline 2410009 & Pilões & 800.562 & 987.508 & 1.236 .657 & 1.598 .747 & 1.903 .810 & 2.248 .607 & 2.262 .222 & 2.466 .288 & 2.659 .218 & 3.160 .955 \\
\hline 2410108 & Poço Branco & 2.744 .195 & 3.205 .186 & 3.530 .671 & 3.493 .109 & 1.464 .514 & 891.332 & 1.106 .957 & 1.266 .754 & 1.913 .289 & 2.571 .435 \\
\hline 2410207 & Portalegre & 2.193 .899 & 2.600 .793 & 3.062 .136 & 3.793 .974 & 4.392 .334 & 5.176 .685 & 5.517 .606 & 5.566 .176 & 6.273 .346 & 7.477.895 \\
\hline 2410256 & Porto do Mangue & 0 & 0 & 29.131 & 41.128 & 38.894 & 45.961 & 44.650 & 46.612 & 59.808 & 68.623 \\
\hline 2410306 & Presidente Juscelino & 1.906 .753 & 2.281 .801 & 2.705 .944 & 3.069 .795 & 3.138 .932 & 3.046 .547 & 3.286 .800 & 3.487 .509 & 3.959 .619 & 4.769 .970 \\
\hline 2410405 & Pureza & 1.068 .825 & 1.292 .695 & 1.454 .094 & 1.762 .480 & 954.779 & 271.642 & 295.575 & 321.346 & 524.588 & 886.093 \\
\hline 2410504 & Rafael Fernandes & 871.769 & 1.093 .800 & 1.341 .555 & 1.608 .642 & 1.982 .709 & 2.524 .304 & 2.846 .519 & 2.972 .438 & 3.204 .195 & 3.793 .680 \\
\hline 2410603 & Rafael Godeiro & 902.716 & 1.111 .340 & 1.337 .432 & 1.632 .800 & 1.843 .924 & 2.103 .508 & 2.372 .105 & 2.642 .921 & 2.885 .598 & 3.329 .521 \\
\hline 2410702 & Riacho da Cruz & 633.896 & 733.452 & 867.283 & 1.048 .791 & 1.215 .895 & 1.383 .109 & 1.331 .370 & 1.331 .988 & 1.492 .135 & 1.756 .318 \\
\hline 2410801 & Riacho de Santana & 1.269 .860 & 1.502 .136 & 1.745 .612 & 2.170 .475 & 2.455 .000 & 2.890 .862 & 3.155 .309 & 3.315 .338 & 3.622 .662 & 4.186 .553 \\
\hline 2410900 & Riachuelo & 1.241 .242 & 1.529 .373 & 1.706 .778 & 1.787 .057 & 1.775 .221 & 1.785 .966 & 1.690 .777 & 1.596 .125 & 2.013 .338 & 2.647 .874 \\
\hline 2408953 & Rio do Fogo & 25.401 & 663.870 & 951.168 & 1.202 .275 & 1.096 .935 & 1.034 .005 & 1.173 .904 & 1.432 .211 & 1.728 .491 & 1.946 .960 \\
\hline 2411007 & Rodolfo Fernandes & 1.299 .517 & 1.572 .176 & 1.916 .428 & 2.094 .806 & 1.978 .185 & 2.021 .119 & 2.191 .087 & 2.354 .349 & 2.737 .439 & 3.220 .904 \\
\hline 2411106 & Ruy Barbosa & 1.020 .203 & 1.190 .442 & 1.331 .456 & 1.299 .076 & 1.392 .298 & 1.458 .553 & 1.540 .035 & 1.672 .317 & 1.870 .719 & 2.234 .672 \\
\hline 2411205 & Santa Cruz & 9.993 .444 & 12.021 .886 & 14.999 .720 & 24.939 .892 & 33.625 .392 & 44.981 .347 & 57.356 .132 & 63.242 .343 & 67.850 .775 & 76.689 .931 \\
\hline 2409332 & Santa Maria & 28.544 & 477.799 & 472.151 & 281.043 & 425.943 & 559.393 & 610.925 & 729.143 & 962.841 & 1.299 .092 \\
\hline 2411403 & Santana do Matos & 4.643 .082 & 5.356 .825 & 6.129 .735 & 7.388 .989 & 8.428 .365 & 9.344 .356 & 10.761 .223 & 11.870 .959 & 13.119 .767 & 15.080 .213 \\
\hline 2411429 & Santana do Seridó & 626.635 & 728.438 & 823.388 & 812.476 & 835.960 & 773.648 & 688.467 & 468.829 & 520.151 & 610.530 \\
\hline 2411502 & Santo Antônio & 10.323 .738 & 12.155 .168 & 13.871 .492 & 16.670 .325 & 18.048 .271 & 19.922 .087 & 23.549 .138 & 26.384 .359 & 29.041 .288 & 33.722 .918 \\
\hline 2411601 & São Bento do Norte & 2.379 .492 & 2.741 .844 & 2.791 .876 & 2.480 .727 & 2.197 .594 & 2.160 .481 & 2.247.279 & 2.374 .790 & 2.479 .907 & 2.806 .702 \\
\hline 2411700 & São Bento do Trairí & 890.673 & 1.008 .367 & 1.161 .143 & 1.431 .683 & 1.374 .353 & 1.300 .500 & 1.326 .867 & 1.434 .238 & 1.710 .157 & 2.120 .513 \\
\hline 2411809 & São Fernando & 814.946 & 1.010 .265 & 1.218 .768 & 1.346 .433 & 1.350 .370 & 1.407 .006 & 1.640 .474 & 1.954 .491 & 2.285 .537 & 2.736 .325 \\
\hline 2411908 & $\begin{array}{c}\text { São Francisco do } \\
\text { Oeste }\end{array}$ & 833.682 & 1.002 .668 & 1.219 .392 & 1.522 .992 & 1.723 .277 & 2.063 .745 & 2.369 .696 & 2.558 .935 & 2.725 .540 & 3.133 .572 \\
\hline 2412005 & $\begin{array}{c}\text { São Gonçalo do } \\
\text { Amarante }\end{array}$ & 3.664 .632 & 4.383 .364 & 5.485 .316 & 12.057 .905 & 22.431 .229 & 30.892 .438 & 38.768 .908 & 42.905 .339 & 49.819 .307 & 56.252 .141 \\
\hline 2412104 & São João do Sabugi & 1.890 .417 & 2.262 .154 & 2.535 .710 & 2.597 .656 & 2.348 .266 & 2.654 .665 & 3.132 .778 & 3.628 .438 & 4.231 .037 & 5.050 .086 \\
\hline 2412203 & São José de Mipibu & 8.370 .062 & 9.825 .087 & 11.221.479 & 13.404 .223 & 15.363 .993 & 17.269 .871 & 19.907.391 & 21.876 .512 & 24.274 .724 & 27.828 .925 \\
\hline 2412302 & $\begin{array}{l}\text { São José do } \\
\text { Campestre }\end{array}$ & 4.200 .787 & 5.027 .470 & 5.790 .937 & 6.418 .222 & 6.961 .953 & 7.589 .344 & 8.919 .803 & 9.861 .496 & 11.113 .851 & 12.839 .580 \\
\hline 2412401 & São José do Seridó & 905.168 & 1.134 .153 & 1.371 .638 & 1.716 .337 & 1.690 .226 & 1.866 .598 & 2.087 .984 & 2.389 .889 & 2.906 .694 & 3.518 .376 \\
\hline 2412500 & São Miguel & 9.298 .817 & 10.839 .261 & 12.512 .722 & 15.611 .743 & 18.340 .079 & 22.427 .636 & 26.207 .342 & 28.712 .590 & 31.009 .942 & 35.071 .618 \\
\hline 2412559 & São Miguel de Touros & 546.035 & 656.395 & 781.124 & 784.406 & 639.177 & 571.346 & 558.044 & 651.900 & 891.184 & 1.204 .128 \\
\hline 2412609 & São Paulo do Potengi & 5.846 .077 & 6.854 .666 & 8.070 .213 & 9.773 .387 & 10.732 .206 & 11.754 .709 & 13.635 .738 & 15.003 .064 & 16.419 .405 & 18.515 .159 \\
\hline 2412708 & São Pedro & 1.684 .143 & 1.898 .688 & 2.173 .306 & 2.562 .718 & 2.662 .641 & 2.646 .215 & 2.617 .518 & 2.387 .732 & 2.686 .476 & 3.214 .883 \\
\hline 2412807 & São Rafael & 2.670 .555 & 3.169 .159 & 3.587 .699 & 3.824 .145 & 3.625 .278 & 3.719 .920 & 4.134 .478 & 4.582 .605 & 5.102 .841 & 6.100 .656 \\
\hline 2412906 & São Tomé & 3.774 .856 & 4.456 .909 & 4.900 .721 & 5.280 .337 & 5.427 .057 & 5.660 .951 & 6.061 .327 & 6.525 .014 & 7.314 .564 & 8.459 .665 \\
\hline 2413003 & São Vicente & 1.817 .813 & 1.862 .460 & 2.111 .735 & 2.417 .608 & 2.525 .905 & 2.685 .672 & 2.900 .932 & 3.197 .510 & 3.556 .370 & 4.234 .968 \\
\hline 2413102 & Senador Elói de Souza & 935.238 & 1.095 .455 & 1.287 .335 & 1.405 .422 & 1.348 .438 & 1.400 .210 & 1.586 .294 & 1.779 .790 & 2.045 .595 & 2.346 .038 \\
\hline
\end{tabular}




\begin{tabular}{|c|c|c|c|c|c|c|c|c|c|c|c|}
\hline 2413201 & $\begin{array}{c}\text { Senador Georgino } \\
\text { Avelino }\end{array}$ & 517.372 & 599.582 & 684.509 & 764.495 & 727.788 & 734.057 & 678.287 & 782.560 & 912.948 & 1.131 .005 \\
\hline 2413300 & Serra de São Bento & 1.476 .207 & 1.736 .603 & 2.012 .494 & 2.253 .205 & 2.468 .980 & 2.568 .450 & 2.767 .254 & 2.991 .629 & 3.430 .597 & 4.176 .826 \\
\hline 2413359 & Serra do Mel & 1.013 .205 & 1.144 .850 & 981.805 & 328.070 & 256.114 & 242.673 & 234.039 & 197.975 & 235.961 & 445.895 \\
\hline 2413409 & Serra Negra do Norte & 2.556 .863 & 3.027 .803 & 3.417 .535 & 3.748 .953 & 3.935 .745 & 4.318 .192 & 4.969 .125 & 5.495 .052 & 6.111 .342 & 7.144 .637 \\
\hline 2413508 & Serrinha & 1.664 .981 & 1.990 .135 & 2.318 .072 & 2.522 .300 & 2.600 .011 & 2.767 .991 & 2.902 .179 & 2.977 .962 & 3.504 .998 & 4.295 .449 \\
\hline 2413557 & Serrinha dos Pintos & 119.374 & 422.894 & 604.617 & 832.984 & 1.137 .373 & 1.465 .516 & 1.745 .579 & 1.803 .026 & 2.038 .734 & 2.487 .983 \\
\hline 2413607 & Severiano Melo & 1.874 .465 & 2.246 .433 & 2.637 .913 & 3.102 .292 & 3.213 .172 & 3.560 .715 & 3.508 .705 & 2.783 .692 & 3.269 .800 & 4.176 .995 \\
\hline 2413706 & Sítio Novo & 1.196 .708 & 1.393 .927 & 1.537 .425 & 1.448 .755 & 1.382 .791 & 1.373 .623 & 1.334 .458 & 1.495 .712 & 1.805 .380 & 2.275 .354 \\
\hline 2413805 & Taboleiro Grande & 570.412 & 690.947 & 689.928 & 486.448 & 532.501 & 640.536 & 619.761 & 637.506 & 733.217 & 928.045 \\
\hline 2413904 & Taipu & 3.205 .336 & 3.769 .738 & 4.167.544 & 2.485 .716 & 1.133 .376 & 1.018 .539 & 1.205 .100 & 1.401 .175 & 2.220 .914 & 3.157 .752 \\
\hline 2414001 & Tangará & 2.604 .465 & 3.054 .313 & 3.565 .796 & 4.192 .211 & 4.307 .877 & 4.458 .025 & 4.763 .969 & 5.092 .930 & 5.912 .971 & 7.229 .683 \\
\hline 2414100 & Tenente Ananias & 2.879 .379 & 3.507 .924 & 4.196 .185 & 5.259 .731 & 6.008 .482 & 6.831 .178 & 6.823 .929 & 7.065 .358 & 7.436 .949 & 8.746 .409 \\
\hline 2414159 & $\begin{array}{c}\text { Tenente Laurentino } \\
\text { Cruz }\end{array}$ & 354.819 & 1.222 .926 & 1.465 .021 & 1.865 .059 & 1.864 .671 & 1.683 .085 & 1.864 .395 & 2.183 .409 & 2.507 .682 & 3.140 .562 \\
\hline 2411056 & Tibau & 0 & 0 & 59.760 & 12.764 & 11.402 & 11.220 & 21.023 & 45.229 & 94.566 & 153.802 \\
\hline 2414209 & Tibau do Sul & 925.537 & 1.090 .259 & 1.256 .761 & 1.391 .624 & 1.409 .097 & 1.543 .135 & 1.684 .140 & 1.765 .864 & 2.141 .623 & 2.633 .162 \\
\hline 2414308 & Timbaúba dos Batistas & 728.059 & 877.200 & 1.034 .385 & 1.258 .283 & 1.189 .664 & 1.170 .217 & 1.286 .815 & 1.505 .342 & 1.738 .712 & 2.026 .587 \\
\hline 2414407 & Touros & 7.018 .665 & 8.350 .302 & 9.577 .422 & 11.924 .380 & 13.354 .487 & 14.594 .331 & 16.645 .278 & 18.408 .884 & 20.025 .717 & 23.042 .133 \\
\hline 2414456 & Triunfo Potiguar & 0 & 168.303 & 325.427 & 377.311 & 407.290 & 338.555 & 342.648 & 517.310 & 730.181 & 942.777 \\
\hline 2414506 & Umarizal & 4.512 .205 & 5.451 .931 & 6.332 .375 & 7.740 .043 & 8.809 .991 & 10.343 .051 & 12.490 .485 & 13.989 .670 & 15.386 .581 & 17.139 .745 \\
\hline 2414605 & Upanema & 2.603 .141 & 3.034 .871 & 3.515 .344 & 3.935 .684 & 4.082 .425 & 4.345 .291 & 3.940 .431 & 3.017 .009 & 3.736 .686 & 4.738 .522 \\
\hline 2414704 & Várzea & 2.958 .157 & 3.364 .942 & 3.392 .642 & 3.195 .992 & 3.124 .517 & 2.898 .773 & 2.840 .007 & 2.789 .790 & 3.118 .773 & 3.664 .034 \\
\hline 2414753 & Venha-Ver & 99.251 & 398.031 & 591.710 & 900.066 & 1.154 .660 & 1.521 .273 & 1.639 .905 & 1.746 .549 & 1.912 .493 & 2.362 .524 \\
\hline 2414803 & Vera Cruz & 2.064 .749 & 2.475 .801 & 2.843 .740 & 3.448 .510 & 3.648 .875 & 3.871 .208 & 4.162 .492 & 4.296 .030 & 4.832 .096 & 6.041 .252 \\
\hline 2414902 & Viçosa & 333.132 & 380.141 & 448.975 & 574.165 & 676.837 & 786.177 & 834.058 & 817.897 & 812.806 & 902.329 \\
\hline 2415008 & Vila Flor & 197.816 & 248.516 & 301.124 & 369.533 & 265.693 & 146.110 & 100.906 & 148.650 & 219.680 & 292.718 \\
\hline \multicolumn{2}{|l|}{ Ignorado } & 0 & 0 & 0 & 0 & 0 & 0 & 0 & 0 & 0 & 0 \\
\hline \multicolumn{2}{|l|}{ Total } & 848.661 .700 & 991.535 .295 & 1.144 .126 .727 & 1.395 .832 .475 & 1.607 .741 .903 & 1.821 .945 .852 & 2.090 .533 .343 & 2.288 .253 .502 & 2.515 .295 .474 & 2.886 .389 .203 \\
\hline
\end{tabular}

Fonte: SINTESE/DATAPREV

Nota: O Valor dos benefícios emitidos corresponde ao valor líquido (diferença entre valor bruto e descontos) dos créditos emitidos pelo Instituto Nacional de Previdência Social - INSS para pagamento de benefícios do Regime Geral de Previdência Social, Encargos Previdenciários da União e Amparos Assistenciais previstos na Lei Orgânica da Assistência Social, classificados pelo município do órgão pagador. 
ANEXO II

VALOR ARRECADADO PELO INSS, SEGUNDO OS MUNICÍPIOS ESTADO DO RIO GRANDE DO NORTE - 2000 A 2009

\begin{tabular}{|c|c|c|c|c|c|c|c|c|c|c|c|}
\hline \multirow{3}{*}{$\begin{array}{l}\text { CóDIGO } \\
\text { IBGE }\end{array}$} & \multirow{3}{*}{ MUNICÍPIO } & & & & & & & & & & \multirow{3}{*}{$\begin{array}{c}\text { Valores em } \mathrm{R} \$ \\
\mathbf{2 0 0 9}\end{array}$} \\
\hline & & \multicolumn{9}{|c|}{ VALOR ARRECADADO } & \\
\hline & & 2000 & 2001 & 2002 & 2003 & 2004 & 2005 & 2006 & 2007 & 2008 & \\
\hline 2400109 & Acari & 405.872 & 788.970 & 929.432 & 1.122 .971 & 1.373 .994 & 1.754 .084 & 2.187 .260 & 2.580 .576 & 2.949 .653 & 2.579 .173 \\
\hline 2400208 & Açu & 2.543 .615 & 3.020 .677 & 4.829 .063 & 6.884 .406 & 7.810 .565 & 9.383 .513 & 11.535 .661 & 13.809 .162 & 20.841 .953 & 27.135 .106 \\
\hline 2400307 & Afonso Bezerra & 85.552 & 279.279 & 460.809 & 618.476 & 621.192 & 854.430 & 1.072 .244 & 1.122 .006 & 1.179 .286 & 1.351 .300 \\
\hline 2400406 & Água Nova & 0 & 0 & 0 & 0 & 0 & 0 & 0 & 0 & 0 & 0 \\
\hline 2400505 & Alexandria & 329.171 & 854.183 & 1.326 .934 & 1.475 .340 & 1.548 .358 & 2.360 .465 & 3.374 .861 & 4.098 .327 & 4.904 .320 & 4.997 .971 \\
\hline 2400604 & Almino Afonso & 0 & 0 & 0 & 0 & 0 & 0 & 0 & 0 & 0 & 0 \\
\hline 2400703 & Alto do Rodrigues & 0 & 0 & 0 & 0 & 0 & 0 & 0 & 0 & 0 & 0 \\
\hline 2400802 & Angicos & 481.813 & 1.004 .387 & 1.242 .807 & 1.307 .000 & 1.240 .664 & 1.693 .977 & 2.102 .016 & 2.420 .499 & 2.775 .026 & 2.868 .463 \\
\hline 2400901 & Antônio Martins & 0 & 0 & 0 & 0 & 0 & 0 & 0 & 0 & 0 & 0 \\
\hline 2401008 & Apodi & 929.245 & 2.821 .456 & 2.917 .060 & 3.370 .664 & 4.288 .133 & 5.782 .135 & 7.441 .207 & 8.161 .839 & 9.329 .139 & 9.471 .281 \\
\hline 2401107 & Areia Branca & 1.344 .367 & 2.607 .723 & 3.396 .694 & 4.960 .418 & 5.379 .158 & 7.277 .197 & 8.294 .042 & 9.371 .582 & 10.844 .118 & 8.105 .855 \\
\hline 2401206 & Arês & 0 & 0 & 0 & 0 & 0 & 0 & 0 & 0 & 0 & 0 \\
\hline 2401305 & Augusto severo & 315.750 & 989.818 & 1.477 .504 & 1.860 .411 & 2.003 .173 & 2.588 .108 & 3.447 .802 & 4.131 .559 & 4.571 .366 & 5.012 .135 \\
\hline 2401404 & Baía Formosa & 0 & 0 & 0 & 0 & 0 & 0 & 0 & 0 & 0 & 0 \\
\hline 2401453 & Baraúna & 188.956 & 577.209 & 825.305 & 964.716 & 605.082 & 1.576 .027 & 1.724 .164 & 1.402 .016 & 2.043 .793 & 3.737 .788 \\
\hline 2401503 & Barcelona & 0 & 0 & 0 & 0 & 0 & 0 & 0 & 0 & 0 & 0 \\
\hline 2401602 & Bento Fernandes & 0 & 0 & 0 & 0 & 0 & 0 & 0 & 0 & 0 & 0 \\
\hline 2401651 & Bodó & 0 & 0 & 0 & 0 & 0 & 0 & 0 & 0 & 0 & 0 \\
\hline 2401701 & Bom Jesus & 0 & 0 & 0 & 0 & 0 & 0 & 0 & 0 & 0 & 0 \\
\hline 2401800 & Brejinho & 0 & 0 & 0 & 0 & 0 & 0 & 0 & 0 & 0 & 0 \\
\hline 2401859 & Caiçara do Norte & 0 & 0 & 0 & 0 & 0 & 0 & 0 & 0 & 0 & 0 \\
\hline 2401909 & Caiçara do Rio do Vento & 0 & 0 & 0 & 0 & 0 & 0 & 0 & 0 & 0 & 0 \\
\hline 2402006 & Caicó & 4.544 .309 & 6.645 .949 & 8.084 .390 & 9.949.299 & 11.875 .615 & 14.192 .237 & 17.731 .307 & 20.531 .671 & 24.498 .379 & 27.301 .471 \\
\hline 2402105 & Campo Redondo & 0 & 0 & 0 & 0 & 0 & 0 & 0 & 0 & 0 & 0 \\
\hline 2402204 & Canguaretama & 656.716 & 1.915 .101 & 3.700 .429 & 4.655 .098 & 6.125 .354 & 7.920 .916 & 7.770 .994 & 11.977 .494 & 11.853 .172 & 11.389 .945 \\
\hline 2402303 & Caraúbas & 339.308 & 685.587 & 1.131 .623 & 1.261 .512 & 1.233 .396 & 1.817 .812 & 2.429 .019 & 2.845 .080 & 2.939 .504 & 2.434 .082 \\
\hline 2402402 & Carnaúba dos Dantas & 0 & 0 & 0 & 0 & 33.162 & 71.589 & 77.886 & 354.179 & 1.018 .376 & 1.193 .620 \\
\hline
\end{tabular}




\begin{tabular}{|c|c|c|c|c|c|c|c|c|c|c|c|}
\hline 2402501 & Carnaubais & 0 & 0 & 0 & 0 & 0 & 0 & 0 & 0 & 0 & 0 \\
\hline 2402600 & Ceará-Mirim & 2.302 .129 & 3.917 .791 & 4.703 .385 & 5.773 .987 & 5.841 .926 & 7.661 .854 & 8.634 .638 & 13.203 .724 & 13.839 .569 & 13.632.251 \\
\hline 2402709 & Cerro Corá & 0 & 0 & 0 & 0 & 0 & 0 & 0 & 0 & 0 & 0 \\
\hline 2402808 & Coronel Ezequiel & 0 & 0 & 0 & 0 & 0 & 0 & 0 & 0 & 0 & 0 \\
\hline 2402907 & Coronel João Pessoa & 0 & 0 & 0 & 0 & 0 & 0 & 0 & 0 & 0 & 0 \\
\hline 2403004 & Cruzeta & 0 & 0 & 0 & 0 & 0 & 0 & 0 & 0 & 0 & 0 \\
\hline 2403103 & Currais Novos & 2.734 .815 & 3.335 .799 & 4.459 .161 & 4.975 .142 & 5.631 .789 & 7.581 .161 & 10.422 .517 & 12.270 .983 & 14.810 .689 & 16.376 .250 \\
\hline 2403202 & Doutor Severiano & 0 & 0 & 0 & 0 & 0 & 0 & 0 & 0 & 0 & 0 \\
\hline 2403301 & Encanto & 0 & 0 & 0 & 0 & 0 & 0 & 0 & 0 & 0 & 0 \\
\hline 2403400 & Equador & 0 & 0 & 0 & 0 & 0 & 0 & 0 & 0 & 0 & 0 \\
\hline 2403509 & Espírito Santo & 0 & 0 & 0 & 0 & 0 & 0 & 0 & 0 & 0 & 0 \\
\hline 2403608 & Extremoz & 0 & 0 & 0 & 0 & 0 & 0 & 0 & 0 & 0 & 0 \\
\hline 2403707 & Felipe Guerra & 0 & 0 & 0 & 0 & 0 & 0 & 0 & 0 & 0 & 0 \\
\hline 2403756 & Fernando Pedroza & 0 & 0 & 0 & 0 & 0 & 0 & 0 & 0 & 0 & 0 \\
\hline 2403806 & Florânia & 321.198 & 717.605 & 930.561 & 1.152 .824 & 1.172 .435 & 1.598 .033 & 2.061 .112 & 2.240 .385 & 2.209 .879 & 2.434 .812 \\
\hline 2403905 & Francisco Dantas & 0 & 0 & 0 & 0 & 0 & 0 & 0 & 0 & 0 & 0 \\
\hline 2404002 & Frutuoso Gomes & 0 & 0 & 0 & 0 & 0 & 0 & 0 & 0 & 0 & 0 \\
\hline 2404101 & Galinhos & 0 & 0 & 0 & 0 & 0 & 0 & 0 & 0 & 0 & 0 \\
\hline 2404200 & Goianinha & 2.517 .563 & 4.462 .984 & 3.675 .399 & 3.882 .061 & 4.411 .757 & 5.921 .135 & 7.337 .719 & 9.111 .242 & 11.680 .015 & 12.873 .169 \\
\hline 2404309 & Governador Dix-Sept Rosado & 271.798 & 527.161 & 744.966 & 930.997 & 1.069 .580 & 1.325 .389 & 1.956 .554 & 2.358 .432 & 2.359 .114 & 1.851 .205 \\
\hline 2404408 & Grossos & 0 & 0 & 0 & 0 & 0 & 0 & 0 & 0 & 0 & 0 \\
\hline 2404507 & Guamaré & 0 & 0 & 0 & 0 & 443.102 & 1.914 .090 & 2.507 .139 & 2.673 .549 & 5.964 .977 & 5.522 .384 \\
\hline 2404606 & Ielmo Marinho & 0 & 0 & 0 & 0 & 0 & 0 & 0 & 0 & 0 & 0 \\
\hline 2404705 & Ipanguaçu & 316.598 & 834.633 & 1.051 .151 & 1.348 .978 & 1.686 .803 & 2.207 .715 & 2.961 .441 & 2.510 .102 & 2.153 .372 & 2.618 .748 \\
\hline 2404804 & Ipueira & 0 & 0 & 0 & 0 & 0 & 0 & 0 & 0 & 0 & 0 \\
\hline 2404853 & Itajá & 0 & 0 & 0 & 0 & 0 & 0 & 0 & 0 & 0 & 0 \\
\hline 2404903 & Itaú & 0 & 0 & 0 & 0 & 0 & 0 & 0 & 0 & 0 & 0 \\
\hline 2405009 & Jaçanã & 0 & 0 & 0 & 0 & 0 & 0 & 0 & 0 & 0 & 0 \\
\hline 2405108 & Jandaíra & 0 & 0 & 0 & 0 & 0 & 0 & 0 & 0 & 0 & 0 \\
\hline 2405207 & Janduís & 0 & 0 & 0 & 0 & 0 & 0 & 0 & 0 & 0 & 0 \\
\hline 2405306 & Januário Cicco & 0 & 0 & 0 & 0 & 0 & 0 & 0 & 0 & 0 & 0 \\
\hline 2405405 & Japi & 0 & 0 & 0 & 0 & 0 & 0 & 0 & 0 & 0 & 0 \\
\hline 2405504 & Jardim de Angicos & 0 & 0 & 0 & 0 & 0 & 0 & 0 & 0 & 0 & 0 \\
\hline 2405603 & Jardim de Piranhas & 0 & 0 & 0 & 0 & 0 & 0 & 0 & 0 & 0 & 0 \\
\hline 2405702 & Jardim do Seridó & 527.385 & 1.007 .820 & 1.328 .506 & 1.446 .186 & 1.515 .340 & 1.979 .672 & 2.367 .741 & 2.651 .957 & 3.007 .406 & 2.739 .533 \\
\hline 2405801 & João Câmara & 821.201 & 2.671 .328 & 3.492 .999 & 4.251 .230 & 4.674 .037 & 6.086 .436 & 7.441 .950 & 8.824 .278 & 9.514 .859 & 10.992 .021 \\
\hline 2405900 & João Dias & 0 & 0 & 0 & 0 & 0 & 0 & 0 & 0 & 0 & 0 \\
\hline 2406007 & José da Penha & 0 & 0 & 0 & 0 & 0 & 0 & 0 & 0 & 0 & 0 \\
\hline 2406106 & Jucurutu & 155.275 & 383.015 & 623.174 & 767.384 & 862.360 & 1.224 .243 & 1.747 .527 & 2.558 .387 & 2.913 .247 & 3.518 .644 \\
\hline 2406155 & Jundiá & 0 & 0 & 0 & 0 & 0 & 0 & 0 & 0 & 0 & 0 \\
\hline
\end{tabular}




2406205
2406304
2406403
2406502
2406601
2406700
2406809
2406908
2407005
2407104
2407203
2407252
2407302
2407401
2407500
2407609
2407708
2407807
2407906
2408003
2408102
2408201
2408300
2408409
2408508
2408607
2408706
2408805
2408904
2403251
2409100
2409209
2409308
2409407
2409506
2409605
2409704
2409803
2409902
2410009

Lagoa d'Anta Lagoa de Pedras Lagoa de Velhos Lagoa Nova

Lagoa Salgada Lajes

Lajes Pintadas Lucrécia

Luís Gomes Macaíba Macau

Major Sales Marcelino Vieira Martins

Maxaranguape Messias Targino Montanhas

Monte Alegre

Monte das Gameleiras Mossoró

$$
\text { Natal }
$$

Nísia Flores

Nova Cruz

Olho-d'Água do Borges

Ouro Branco

Paraná

Paraú

Parazinho

Parelhas

Parnamirim

Passa e Fica

Passagem

Patu

Pau dos Ferro

Pedra Grande

Pedra Preta

Pedro Avelino

Pedro Velho

Pendência

Pilões

\begin{tabular}{|c|c|c|}
\hline 0 & 0 & 0 \\
\hline 0 & 0 & 0 \\
\hline 0 & 0 & 0 \\
\hline 0 & 0 & 0 \\
\hline 0 & 0 & 0 \\
\hline 417.542 & 738.428 & 1.079 .449 \\
\hline 0 & 0 & 0 \\
\hline 0 & 0 & 0 \\
\hline 0 & 0 & 0 \\
\hline 916.344 & 2.468 .942 & 3.528 .132 \\
\hline 1.756 .020 & 3.638 .761 & 5.430 .643 \\
\hline 0 & 0 & 0 \\
\hline 0 & 0 & 0 \\
\hline 308.002 & 463.163 & 620.208 \\
\hline 0 & 0 & 0 \\
\hline 0 & 0 & 0 \\
\hline 0 & 0 & 0 \\
\hline 450.907 & 1.405 .646 & 2.019 .814 \\
\hline 0 & 0 & 0 \\
\hline 16.417 .637 & 26.241 .896 & 37.138 .289 \\
\hline 184.651 .757 & 213.501 .512 & 267.361 .788 \\
\hline 0 & 0 & 0 \\
\hline 648.859 & 1.605 .582 & 1.965 .634 \\
\hline 0 & 0 & 0 \\
\hline 0 & 0 & 0 \\
\hline 0 & 0 & 0 \\
\hline 0 & 0 & 0 \\
\hline 0 & 0 & 0 \\
\hline 889.475 & 1.693 .050 & 2.114 .805 \\
\hline 5.293 .767 & 8.020 .052 & 10.068 .315 \\
\hline 0 & 0 & 0 \\
\hline 0 & 0 & 0 \\
\hline 581.365 & 1.122 .795 & 1.451 .597 \\
\hline 1.515 .962 & 3.090 .313 & 4.526 .285 \\
\hline 0 & 0 & 0 \\
\hline 0 & 0 & 0 \\
\hline 94.572 & 357.151 & 585.640 \\
\hline 0 & 0 & 0 \\
\hline 0 & 0 & 0 \\
\hline 0 & 0 & 0 \\
\hline
\end{tabular}

\begin{tabular}{c|}
0 \\
0 \\
0 \\
0 \\
0 \\
1.263 .600 \\
0 \\
0 \\
0 \\
4.090 .759 \\
7.546 .903
\end{tabular}

\begin{tabular}{c|c|}
0 & 0 \\
0 & 0 \\
0 & 0 \\
0 & 0 \\
0 & 0 \\
1.393 .698 & 1.827 .767 \\
0 & 0 \\
0 & 0 \\
0 & 0
\end{tabular}

0

750.150

0

0

.695 .285

2.695 .285
0

48.103.149

\begin{tabular}{l|l}
2.799 .878 & 2.773 .675
\end{tabular}

\begin{tabular}{|l|l}
57.283 .206 & 66.645 .978 \\
\hline
\end{tabular}

0
2.275 .924

0

0
0

0

2.467 .570

12.361 .882

1.969 .856

5.740 .349

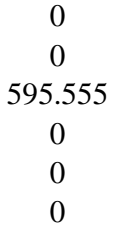

\begin{tabular}{l|l}
4.810 .151 & 7.018 .537
\end{tabular}

8.974 .833

11.185 .224

0

812.391

0

0

0
66.645 .978

\begin{tabular}{|c|c|c|}
\hline 381.107 .400 & 435.733 .291 & 473.600 .542 \\
\hline
\end{tabular}

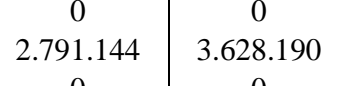

0
0

0
0

0
0
2553.174

15.645 .184

\begin{tabular}{c|c}
0 & 0 \\
0 & 0 \\
2.158 .449 & 2.705 .806 \\
6.366 .645 & 8.671 .970 \\
0 & 0 \\
0 & 0 \\
604.824 & 847.390 \\
0 & 0 \\
0 & 0 \\
0 & 0
\end{tabular}

4.400 .592

\begin{tabular}{c|}
0 \\
0 \\
0 \\
0 \\
0 \\
2.257 .192 \\
0 \\
0 \\
0
\end{tabular}

8.689 .842
3.035 .319

0
0
1.487 .481
0

(

0

3.466 .046

3.466 .046
0

82

4.987 .410
0

97.129 .072

563.320 .387

0
4.707 .881

0

\begin{tabular}{c|}
0 \\
0 \\
0 \\
0 \\
0 \\
2.547 .811 \\
0 \\
0 \\
0 \\
\hline 3.817
\end{tabular}

1.913 .817
4.800 .883

0

1.352 .643

0

.410

6.172.5

111.388 .292

703.565 .040

0
5.444 .309

0

0

0

4.650 .354

36.906 .180

24.184 .891

28.385.477

0

0

3.916 .181
15.068 .287

0

1.092 .124

888.073

0

0

2.742 .320

0

16.936 .838

17.809 .141

0

2.083 .737

0

6.286.107

23.409.847

711.837 .023

0
5.550 .478

0

0

724.657

41.723 .917

0

3.504 .168

16.169 .744

0

1.317.945

0

0 


2410108
2410207
2410256
2410306
2410405
2410504
2410603
2410702
2410801
2410900
2408953
2411007
2411106
2411205
2409332
2411403
2411429
2411502
2411601
2411700
2411809
2411908
2412005
2412104
2412203
2412302
2412401
2412500
2412559
2412609
2412708
2412807
2412906
2413003
2413102
2413201
2413300
2413359
2413409
2413508

Poço Branco Portalegre

Porto do Mangue

Presidente Juscelino Pureza

Rafael Fernandes

Rafael Godeiro

Riacho da Cruz

Riacho de Santana Riachuelo

Rio do Fogo

Rodolfo Fernandes Ruy Barbosa

Santa Cruz

Santa Maria

Santana do Matos

Santana do Seridó

Santo Antônio

São Bento do Norte

São Bento do Trairí

São Fernando

São Francisco do Oeste

São Gonçalo do Amarante

São João do Sabugi

São José de Mipibu

São José do Campestre

São José do Seridó

São Miguel

São Miguel de Touros

São Paulo do Potengi

São Pedro

São Rafael

São Tomé

São Vicente

Senador Elói de Souza

Senador Georgino Avelino Serra de São Bento

Serra do Mel

Serra Negra do Norte Serrinha

\begin{tabular}{|c|c|c|}
\hline 0 & 0 & 0 \\
\hline 0 & 0 & 0 \\
\hline 0 & 0 & 0 \\
\hline 0 & 0 & 0 \\
\hline 0 & 0 & 0 \\
\hline 0 & 0 & 0 \\
\hline 0 & 0 & 0 \\
\hline 0 & 0 & 0 \\
\hline 0 & 0 & 0 \\
\hline 0 & 0 & 0 \\
\hline 0 & 0 & 0 \\
\hline 0 & 0 & 0 \\
\hline 0 & 0 & 0 \\
\hline 1.165 .996 & 2.757 .582 & 9.279 .425 \\
\hline 0 & 0 & 0 \\
\hline 315.492 & 643.310 & 924.326 \\
\hline 0 & 0 & 0 \\
\hline 408.166 & 1.328 .664 & 1.874 .414 \\
\hline 0 & 0 & 0 \\
\hline 0 & 0 & 0 \\
\hline 0 & 0 & 0 \\
\hline 0 & 0 & 0 \\
\hline 8.425 .932 & 6.809 .143 & 879.207 \\
\hline 0 & 0 & 0 \\
\hline 597.574 & 1.646 .113 & 2.469 .282 \\
\hline 236.324 & 639.346 & 792.594 \\
\hline 0 & 0 & 0 \\
\hline 529.642 & 1.053 .249 & 1.626 .685 \\
\hline 0 & 0 & 0 \\
\hline 1.402 .289 & 2.662 .493 & 3.302 .580 \\
\hline 0 & 0 & 0 \\
\hline 0 & 0 & 0 \\
\hline 0 & 0 & 0 \\
\hline 0 & 0 & 0 \\
\hline 0 & 0 & 0 \\
\hline 0 & 0 & 0 \\
\hline 0 & 0 & 0 \\
\hline 0 & 0 & 0 \\
\hline 0 & 0 & 0 \\
\hline 0 & 0 & 0 \\
\hline
\end{tabular}

\begin{tabular}{c|c}
0 & 0 \\
0 & 0 \\
0 & 0 \\
0 & 0 \\
0 & 0 \\
0 & 0 \\
0 & 0 \\
0 & 0 \\
0 & 0 \\
0 & 0 \\
0 & 0 \\
0 & 0 \\
0 & 0 \\
5.171 .680 & 6.457 .798 \\
0 & 0 \\
998.310 & 1.270 .500 \\
0 & 0 \\
2.948 .634 & 4.191 .146 \\
0 & 0 \\
0 & 0 \\
0 & 0 \\
0 & 0 \\
1.678 .764 & 1.592 .684 \\
0 & 0 \\
3.339 .262 & 4.458 .318 \\
908.658 & 1.283 .371 \\
0 & 0 \\
2.163 .933 & 2.539 .765 \\
0 & 0 \\
5.169 .727 & 6.369 .232 \\
0 & 0 \\
0 & 0 \\
0 & 0 \\
0 & 0 \\
0 & 0 \\
0 & 0 \\
0 & 0 \\
0 & 0 \\
0 & 0 \\
0 & 0 \\
& \\
0 & 0 \\
0 & 0 \\
0 & 0 \\
0 & 0 \\
0 & 0 \\
0 & 0 \\
0 & 0 \\
0 & 0 \\
0 & 0 \\
0 & 0
\end{tabular}

\begin{tabular}{|c|c|c|}
\hline 0 & 0 & 0 \\
\hline 0 & 0 & 0 \\
\hline 0 & 0 & 0 \\
\hline 0 & 0 & 0 \\
\hline 0 & 0 & 0 \\
\hline 0 & 0 & 0 \\
\hline 0 & 0 & 0 \\
\hline 0 & 0 & 0 \\
\hline 0 & 0 & 0 \\
\hline 0 & 0 & 0 \\
\hline 0 & 0 & 0 \\
\hline 0 & 0 & 0 \\
\hline 0 & 0 & 0 \\
\hline 10.340 .439 & 12.359 .613 & 13.260 .549 \\
\hline 0 & 0 & 0 \\
\hline 2.096 .160 & 2.635 .177 & 2.987 .412 \\
\hline 0 & 0 & 0 \\
\hline 6.557 .298 & 6.899 .272 & 6.678 .632 \\
\hline 0 & 0 & 0 \\
\hline 0 & 0 & 0 \\
\hline 0 & 0 & 0 \\
\hline 0 & 0 & 0 \\
\hline 11.206 .770 & 14.881 .232 & 16.899 .544 \\
\hline 0 & 0 & 0 \\
\hline 7.796 .917 & 9.341 .996 & 10.163 .135 \\
\hline 2.214 .130 & 2.551 .228 & 3.128 .720 \\
\hline 0 & 0 & 0 \\
\hline 3.995 .298 & 4.910 .530 & 3.665 .781 \\
\hline 0 & 0 & 0 \\
\hline 10.667 .721 & 11.227 .154 & 10.324 .733 \\
\hline 0 & 0 & 0 \\
\hline 0 & 0 & 0 \\
\hline 0 & 0 & 0 \\
\hline 0 & 0 & 0 \\
\hline 0 & 0 & 0 \\
\hline 0 & 0 & 0 \\
\hline 0 & 0 & 0 \\
\hline 0 & 0 & 0 \\
\hline 0 & 0 & 0 \\
\hline 0 & 0 & 0 \\
\hline
\end{tabular}




\begin{tabular}{|c|c|c|c|c|c|c|c|c|c|c|c|}
\hline 2413557 & Serrinha dos Pintos & 0 & 0 & 0 & 0 & 0 & 0 & 0 & 0 & 0 & 0 \\
\hline 2413607 & Severiano Melo & 0 & 0 & 0 & 0 & 0 & 0 & 0 & 0 & 0 & 0 \\
\hline 2413706 & Sítio Novo & 0 & 0 & 0 & 0 & 0 & 0 & 0 & 0 & 0 & 0 \\
\hline 2413805 & Taboleiro Grande & 0 & 0 & 0 & 0 & 0 & 0 & 0 & 0 & 0 & 0 \\
\hline 2413904 & Taipu & 0 & 0 & 0 & 0 & 0 & 0 & 0 & 0 & 0 & 0 \\
\hline 2414001 & Tangará & 0 & 0 & 0 & 0 & 0 & 0 & 0 & 0 & 0 & 0 \\
\hline 2414100 & Tenente Ananias & 0 & 0 & 0 & 0 & 0 & 0 & 0 & 0 & 0 & 0 \\
\hline 2414159 & Tenente Laurentino Cruz & 0 & 0 & 0 & 0 & 0 & 0 & 0 & 0 & 0 & 0 \\
\hline 2411056 & Tibau & 0 & 0 & 0 & 0 & 0 & 0 & 0 & 0 & 0 & 0 \\
\hline 2414209 & Tibau do Sul & 0 & 0 & 0 & 0 & 0 & 0 & 0 & 0 & 0 & 0 \\
\hline 2414308 & Timbaúba dos Batistas & 0 & 0 & 0 & 0 & 0 & 0 & 0 & 0 & 0 & 0 \\
\hline 2414407 & Touros & 437.845 & 1.071 .934 & 1.604 .123 & 2.070 .717 & 2.305 .829 & 3.264 .865 & 4.384 .890 & 5.473 .470 & 5.504 .407 & 6.693 .040 \\
\hline 2414456 & Triunfo Potiguar & 0 & 0 & 0 & 0 & 0 & 0 & 0 & 0 & 0 & 0 \\
\hline 2414506 & Umarizal & 705.366 & 1.125 .436 & 1.630 .560 & 1.794 .858 & 1.975 .308 & 2.687 .611 & 3.587 .933 & 4.229 .761 & 4.658 .348 & 3.577 .296 \\
\hline 2414605 & Upanema & 0 & 0 & 0 & 0 & 0 & 0 & 0 & 0 & 0 & 0 \\
\hline 2414704 & Várzea & 0 & 0 & 0 & 0 & 0 & 0 & 0 & 0 & 0 & 0 \\
\hline 2414753 & Venha-Ver & 0 & 0 & 0 & 0 & 0 & 0 & 0 & 0 & 0 & 0 \\
\hline 2414803 & Vera Cruz & 0 & 0 & 0 & 0 & 0 & 0 & 0 & 0 & 0 & 0 \\
\hline 2414902 & Viçosa & 0 & 0 & 0 & 0 & 0 & 0 & 0 & 0 & 0 & 0 \\
\hline 2415008 & Vila Flor & 0 & 0 & 0 & 0 & 0 & 0 & 0 & 0 & 0 & 0 \\
\hline \multicolumn{2}{|r|}{ Ignorado } & 0 & 0 & 0 & 0 & 0 & 0 & 0 & 0 & 0 & 0 \\
\hline \multicolumn{2}{|r|}{ Total } & 250.299 .471 & 324.133 .036 & 413.605 .147 & 531.577 .816 & 585.408 .057 & 692.694 .537 & \begin{tabular}{|l|l}
798.737 .854 \\
\end{tabular} & 956.676 .676 & 1.167 .207 .222 & 1.211 .611 .971 \\
\hline
\end{tabular}

Fonte: SINTESE/DATAPREY

Nota: O valor arrecadado compreende os recolhimentos provenientes de todas as receitas incluídas na guia de recolhimento da Previdência Social - GPS. Abrange receitas de contribuições sociais (empresas, entidades equiparadas e contribuintes em geral, débitos e parcelamentos administrativos e judiciais, receitas patrimoniais, devolução de benefícios, reclamatórias trabalhistas e outros. Corresponde à rubrica 11 da GPS, ou seja, inclui as contribuições relativas a outras entidades (SESC, INCRA, Salário Educação) e os acréscimos legais (atualização monetária, juros e multas). Os dados são por local de pagamento e o mês de referência é o de processamento da GPS (mês civil). São computadas todas as GPS, mesmo com erros de fechamento (quando a soma dos valores das rubricas é diferente da rubrica de total). 